\title{
ESTABILIDADE FENOTÍPICA E POTENCIALIDADE DE PROGÊNIES OBTIDAS POR CRUZAMENTOS ÓCTUPLOS EM SOJA
}

\section{SAndra Helena Unêda-Trevisoli}

\author{
Engenheira Agrônoma
}

Orientador: Prof. Dr. NATAL ANTONIO VELlO

Tese apresentada à Escola Superior de Agricultura "Luiz de Queiroz", Universidade de São Paulo, para obtenção do titulo de Doutor em Agronomia, Área de Concentração: Genética e Melhoramento de Plantas.

PIRACICABA

Estado de São Paulo - Brasil

Agosto - 1999 
UNÊDA-TREVISOLI, S.H. Estabilidade fenotípica e potencialidade de progênies

obtidas por cruzamentos óctuplos em soja, 1999, 228p.

\section{ERRATA}

\begin{tabular}{|c|c|c|c|}
\hline Página & Linha & Onde se lê & Leia-se \\
\hline 24 & 8 & (Zobel et al., 1988; Crossa, $1990 ; \ldots$ ) & $\begin{array}{l}\text { (Zobel et al., 1988; Crossa et al, } \\
1990 ; \ldots)\end{array}$ \\
\hline 36 & 18 & $\begin{array}{l}\text { Cada parcela... } 0 \text { espaço entre } \\
\text { parcelas foi de } 1,0 \text { metro. A área } \\
\text { total... }\end{array}$ & $\begin{array}{l}\text { Cada parcela... } 0 \text { espaço entre } \\
\text { parcelas foi de } 1,0 \text { metro e a } \\
\text { semeadura foi realizada com } 15 \\
\text { sementes / } m \text { linear. A área total... }\end{array}$ \\
\hline 38 & 18 & 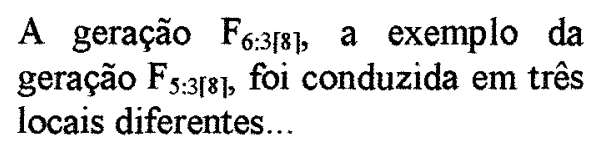 & $\begin{array}{l}\text { A geração } F_{6: 3[8]} \text { foi conduzida em } \\
\text { três locais diferentes... }\end{array}$ \\
\hline 44 & 14 & 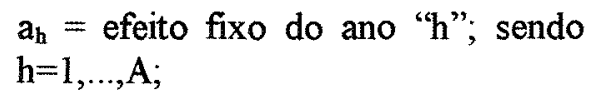 & $\begin{array}{l}a_{h}=\text { efeito aleatório do ano " } h " ; \\
\text { sendo } h=1, \ldots, A\end{array}$ \\
\hline $\begin{array}{c}172 \text { a } 175 \\
\text { (Tabelas } 18 \text { a } 21)\end{array}$ & & $\mathrm{Li}$ & $\mathrm{P}$ \\
\hline $\begin{array}{c}176 \text { a } 179 \\
\text { (Tabelas } 22 \text { a } 25 \text { ) }\end{array}$ & & $\mathrm{Li}$ & $\mathbf{P}$ \\
\hline
\end{tabular}




\section{Dados Internacionais de Catalogação na Publicação (CIP) DIVISÃO DE BIBLIOTECA E DOCUMENTAÇÃO - Campus "Luiz de Queiroz"/USP}

Unêda-Trevisoli, Sandra Helena

Estabilidade fenotipica e potencialidade de progênies obtidas por cruzamentos óctuplos em soja / Sandra Helena Unêda-Trevisoli. - - Piracicaba, 1999.

228 p. : il.

Tese (doutorado) - E Escola Superior de Agricultura Luiz de Queiroz, 1999. Bibliografia.

1. Cruzamento vegetal 2. Estabilidade fenotipica 3. Melhoramento genético vegetal 4. Progênie vegetal 5. Soja I. Título

CDD 633.34

Termitida o copia total on parcial deste documento, desde que citada a fonte 0 Autor" 
Aos meus pais Arlete e Idemar

Aos meus irmãos Maria Lúcia, Luciléia, Gilmar e Stela Aos meus avós e sobrinhos

DEDICO

À Fábio Trevisoli OFEREÇO 
AGRADECIMENTOS

- A Deus, pela sua constante presença em todas as horas;

- Ao Prof. Dr. Natal Antonio Vello, pela orientação, amizade e ensinamentos no decorrer de todo o curso;

- Ao Conselho Nacional de Desenvolvimento Científico e Tecnológico ( $\mathrm{CNPq}$ ) pela concessão da bolsa de doutorado;

- Ao CNPq, à Fundação de Amparo à Pesquisa do Estado de São Paulo (FAPESP) e à Empresa Brasileira de Pesquisa Agropecuária (EMBRAPA) pelo auxílio financeiro em algumas etapas deste trabalho;

- A todos os Professores do Departamento de Genética da ESALQ, pela amizade e ensinamentos importantes durante o curso;

- Ao amigo Rhainer Gleico Cardoso pelo convívio e grande apoio nas análises estatísticas deste trabalho;

- Aos amigos do grupo da soja : Ângela Célis de Almeida Lopes, Cláudio Yuji TsuTsumi, Diego Omar Soldini, Edna Regina Moresco, Fábio Pandini, Fernando T. S. Miranda, Gilberto Ken-Iti Yokomizo, José Baldin Pinheiro, Joaquim Adelino Filho, Jorge Ramon Laínez Mejía, Leandro César Teixeira, Maurisrael de Moura Rocha, Milton Krieger, Regina Lúcia Ferreira Gomes e Vanoli Fronza pelo agradável convívio, amizade e auxilio nos ensaios experimentais;

- Às queridas amigas Ângela Célis de Almeida Lopes e Ana Cláudia Carvalho Badan, pelo apoio, companheirismo, carinho e atenção dispensadas durante todo o nosso convívio;

- Aos funcionários Antônio Roberto Cogo, Claudinei Antônio Didoné e Marcos Custódio Nekatschalow pelo grande apoio prestado nas etapas de condução dos experimentos; 
- Às funcionárias da Biblioteca da Genética e Central Aparecida Elizabeth dos Santos da Silva, Eliana Maria Garcia Sabina, Silvana Cristina Nascimento Oliveira, Silvana Marchizelli Gregório, e Sílvia Zinsly pela atenção sempre dispensada e revisão das referências bibliográficas;

- A todos os funcionários do Departamento da Genética e do Setor de Pós-Graduação pela amizade e atenção prestadas;

- A todos os demais amigos do curso, em especial Leonardo Novaes Rosse, Maria Aldete J. Fonseca Ferreira, Marcelo Akira Naime Nishikawa, Maria Inês Fernandes Faraldo e Rogério Melo Costa Pinto, pela excelente convivência em todos os momentos;

- A todos que, de uma forma ou de outra tenham contribuído para a conclusão deste trabalho. 


\section{INDICE}

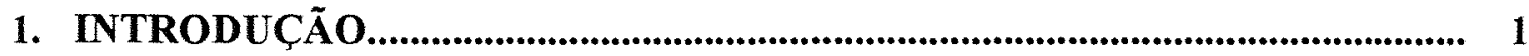

2. REVISÃO DE LITERATURA................................................................... 4

2.1 Caracterização e expansão da soja.............................................................. 5

2.2 Melhoramento genético da soja............................................................... 4

2.3 Utilização da seleção recorrente no melhoramento de soja...................... 6

2.4 Caracteres quantitativos...................................................................................... 14

2.5 Interação genótipo por ambiente................................................................... 16

2.6 Estabilidade fenotípica em soja....................................................................... 23

2.7 Correlações entre caracteres........................................................................ 28

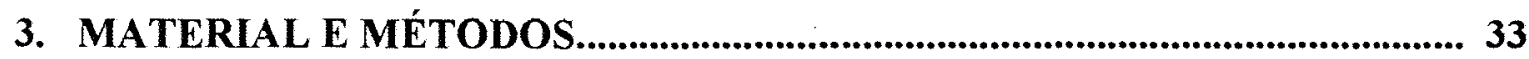

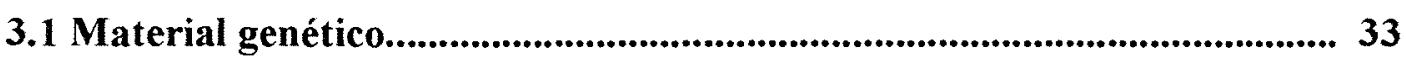

3.2 Caracterização dos ambientes experimentais................................................. 35

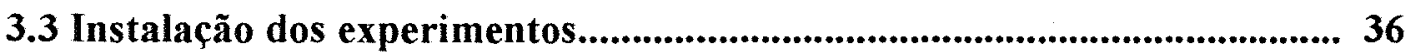

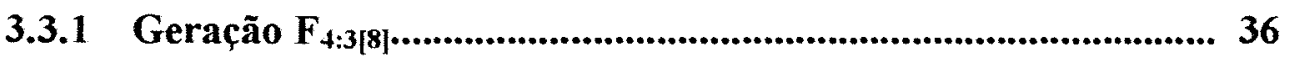

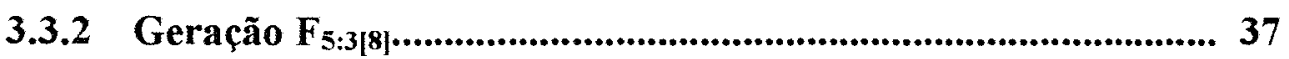

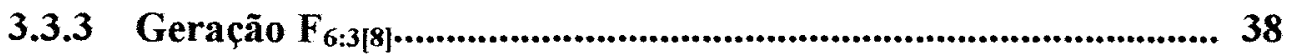

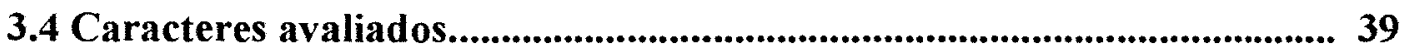

3.5 Análises estatístico-genéticas................................................................. 40

3.5.1 Análise de resíduos............................................................. 41

3.5.2 Análise de variâncias............................................................. 42

3.5.2.1 Análise de variância para testemunhas.......................... 42

3.5.2.2 Análise de variância para tratamentos............................ 44

3.5.3 Estabilidade fenotípica............................................................4 47

3.5.4 Análise de médias e desvios padrões.............................................. 51

3.5.5 Correlação entre caracteres............................................................... 53

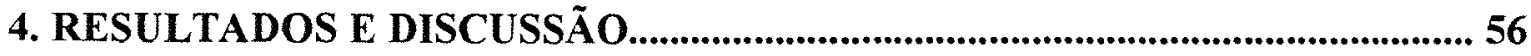

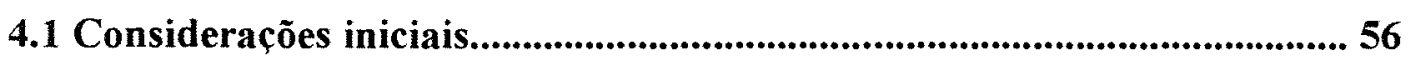

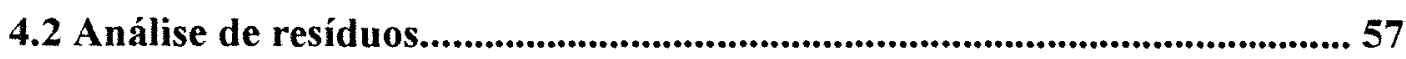

4.3 Análise de variância para testemunhas......................................................... 57

4.3.1. Análise individual de testemunhas..............................................5 58

4.3.2. Análise de testemunhas por ano................................................. 59

4.3.3. Análise de testemunhas conjunta.................................................60 60

4.4. Análise de variância para progênies............................................................. 61 
4.4.1. Análise individual de progênies....................................................... 61

4.4.1.1 Análise em blocos aumentados ...................................... 62

4.4.1.2 Análise em blocos ao acaso............................................. 63

4.4.2. Análise de progênies por ano............................................................ 67

4.4.3. Análise conjunta de progênies........................................................ 73

4.5. Avaliação da estabilidade fenotípica........................................................... 80

4.5.1. Grupo Precoce ................................................................................. 81

4.5.2. Grupo Semi-Precoce .......................................................................... 85

4.5.3. Grupo Intermediário............................................................................ 88

4.5.4. Grupo Semi-Tardio.......................................................................... 91

4.6. Análise de médias e desvios padrões........................................................... 95

4.6.1. Grupo Precoce ................................................................................. 96

4.6.2. Grupo Semi-Precoce ........................................................................100

4.6.3. Grupo Intermediário.........................................................................103

4.6.4. Grupo Semi-Tardio...........................................................................108

4.7. Associação entre a análise de médias e estabilidade.......................111

4.8. Correlações entre caracteres.........................................................................113

4.8.1 Correlações fenotípicas de Pearson...............................................113

4.8.2 Correlações genéticas........................................................................118

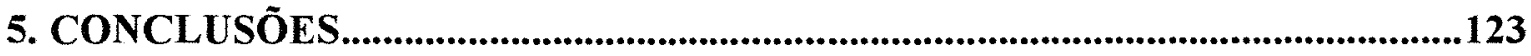

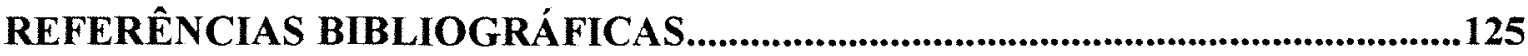

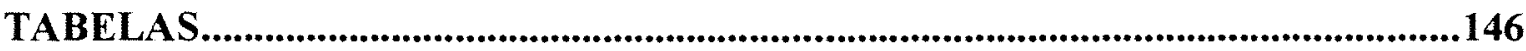

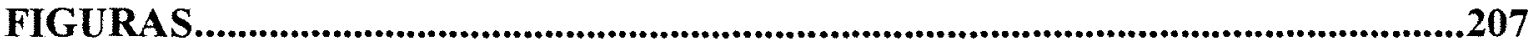

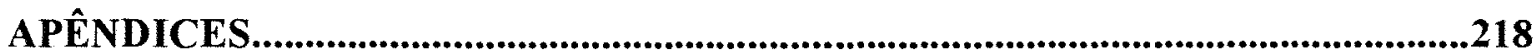




\title{
ESTABILIDADE FENOTÍPICA E POTENCIALIDADE DE PROGÊNIES OBTIDAS POR CRUZAMENTOS ÓCTUPLOS EM SOJA
}

\author{
Autor : Sandra Helena Unêda-Trevisoli \\ Orientador : Prof. Dr. Natal Antonio Vello
}

\section{RESUMO}

O objetivo do presente trabalho foi avaliar a potencialidade e a estabilidade fenotípica de progênies obtidas por cruzamentos óctuplos em soja [ Glycine max (L.) Merrill ], em seis ambientes diferentes (três locais e três anos agrícolas). As progênies, originaram-se a partir de 60 cruzamentos óctuplos, pertencentes ao primeiro ciclo de um programa de seleção recorrente do Setor de Genética Aplicada às Espécies Autógamas, do Departamento de Genética da ESALQ/USP. Os 40 parentais de tais cruzamentos foram selecionados de acordo com critérios de divergência genética, capacidade de combinação e alto potencial produtivo, sendo dez de cada ciclo de maturação (CM) : precoce, semi-precoce, semi-tardio e tardio.

Entende-se por cruzamentos óctuplos, o processo sucessivo de três etapas de recombinações, das quais, a primeira realizou-se em 1989 e envolveu quatro dialelos completos $10 \times 10$, com 45 cruzamentos biparentais para cada CM, totalizando 180 cruzamentos. A segunda geração (1990), foi composta por 45 cruzamentos quádruplos envolvendo os híbridos $F_{1}$ dos ciclos precoce com semi-precoce e 45 cruzamentos quádruplos entre os híbridos $F_{1}$ semi-tardios com tardios. A terceira geração (1991), originou 60 cruzamentos óctuplos, sendo que cada cruzamento foi composto por dois parentais de cada grupo (precoce, semi-precoce, semi-tardio e tardio).

Neste trabalho, foram utilizadas as gerações $F_{4: 3[8]}, F_{5: 3[8]}$ e $F_{6: 3[8]}$, sendo esta simbologia adotada pelo fato de terem sido formado famílias em $F_{3}$. Na geração $F_{4: 3[8]}$, as progênies foram classificadas em $\mathrm{CM}$ precoce, intermediário e semi-tardio; já nas 
gerações $F_{5: 3[8]}$ e $F_{6: 3[8]}$, houve um reagrupamento em : $C M$ precoce (CMP), semiprecoce (CMSP), intermediário (CMI) e semi-tardio (CMST).

A geração $F_{4: 3}$ foi conduzida em um local (campo experimental da ESALQ/USP), no delineamento de blocos aumentados de Federer, em 1995/96, com parcelas de duas fileiras de $5 \mathrm{~m} \times 0,5 \mathrm{~m}$, deixando $1,0 \mathrm{~m}$ de espaçamento entre parcelas; foram avaliadas 715 progênies(229 do CMP, 350 do CMI e 136 do CMST).A geração $\mathrm{F}_{5: 3[8]}$ foi conduzida em dois locais (ESALQ e E. E. Anhembi) e a $\mathrm{F}_{6: 3[8]}$ em três locais (ESALQ, E. E. Anhembi e Fazenda Areão), ambas no delineamento de blocos ao acaso, com repetições estratificadas em conjuntos experimentais e parcelas de quatro fileiras de $5 \mathrm{~m} \times 0,5 \mathrm{~m}$. Avaliou-se 310 progênies em $\mathrm{F}_{5: 3[8]}$ (17 do CMP, 60 do CMSP, 179 do CMI e 54 do CMST) e 127 em $\mathrm{F}_{6: 3[8]}$ (17 do CMP, 30 do CMSP, 60 do CMI e 20 do CMST). Nas gerações, cada CM apresentava dentro dos conjuntos experimentais, quatro testemunhas comuns de ciclos específicos. Foram avaliados os caracteres número de dias para maturidade (NDM), altura de planta na maturidade (APM), acamamento (Ac), valor agronòmico (VA), sintomas de cancro-da-haste da soja (CHS) e produtividade de grãos (PG).

Nas análises de variância individuais, detectou-se variabilidade genética entre progênies (cruzamentos óctuplos) em todos os caracteres e CM, destacando-se o CMI. Em todos os CM, e para todos os caracteres, as progênies (cruzamentos óctuplos) apresentaram maior variabilidade que as testemunhas (cruzamentos biparentais). Os efeitos ambientais foram menos pronunciados para os caracteres valor agronômico (VA) e sintomas de cancro-da-haste (CHS). A capacidade dos locais em discriminar as progênies variou com o ano agrícola, com eficiência decrescente para ESALQ, Anhembi e Areão. O aumento do número de anos agrícolas de avaliação melhorou a discriminação das progênies.

Nas análises de variância por ano e conjunta total, a interação genótipo x local foi mais pronunciada para os caracteres PG e Ac em todos os CM. Por sua vez, os caracteres APM e CHS manifestaram as menores magnitudes de $\mathrm{G} \times \mathrm{L}$. Com relação à interação de genótipo $\mathrm{x}$ ano ( $\mathrm{G} \times \mathrm{A}$ ), esta foi significativa em 20 das 24 interações obtidas entre os seis caracteres avaliados nos quatro CM. A interação tripla progênie $x$ 
local $\mathrm{x}$ ano $(\mathrm{P} \times \mathrm{L} \times \mathrm{A})$ apresentou-se mais significativa que a de testemunhas $(\mathrm{T} \times \mathrm{L} \times$ A) nos CMP, CMSP e CMI, sendo não-significativa no CMST. A análise de estabilidade pelo método da ecovalência, mostrou-se de fácil aplicação e eficiente para a avaliação de genótipos de soja, onde se observou muitas progênies (cruzamentos óctuplos) mais estáveis que as testemunhas (cruzamentos biparentais) em todos os $\mathrm{CM}$ estudados e para a grande maioria dos caracteres. As progênies do CMP foram menos estáveis que aquelas do CMSP, CMI e CMST

As análises de correlação indicaram que a seleção para APM e VA deve também considerar Ac. Com relação a VA, as progênies com maiores notas, tenderam a ser mais produtivas. Apesar das tendências de correlações positivas NDM x PG e NDM x CHS, existiram progènies superiores em PG e sem sintomas de CHS, em todos os CM.

As progênies que mais se destacaram para estabilidade fenotípica e desempenho médio conjunto dos seis caracteres, dentro de cada CM foram : USP97-11.004 (precoce), USP97-11.030 (semi-precoce), USP97-11.097 (intermediária) e USP97-11.110 (semitardia). 


\title{
PHENOTYPIC STABILITY AND AGRONOMIC PERFORMANCE OF SOYBEAN PROGENIES DERIVED FROM MULTIPLE CROSSES
}

\author{
Author: Sandra Helena Unêda-Trevisoli
} Adviser: Natal Antonio Vello

\section{SUMMARY}

This research aimed to evaluate the phenotypic stability agronomic performance of progenies obtained by eight-way crosses in soybean [Glycine max (L.) Merrill], in six different environments (three localities and three agricultural years). The progenies, were derived from 60 eight-way crosses, synthesized by the recurrent selection program carried out in the Setor de Genética Aplicada às Espécies Autógamas, Departamento de Genética, ESALQ/USP. The forty parents of such crosses were chosen based on genetic divergence data, in the combining ability, and on high yield levels. Each set of ten parents belonged to a different maturity cycle (CM): early, semi-early, semi-late and late.

Eight-way crosses were taken in the successive process of three generations of recombination. The first was made in 1989 and involved four $10 \times 10$ complete diallels, with 45 two-way crosses for each maturity cycle, totalizing 180 crosses. The second recombination (1990) was made up of 45 four-way crosses involving $F_{1}$ hybrids between parents from early and semi-early cycles and other 45 four-way crosses between parents from semi-late and late $F_{1}$ hybrids. The third recombination (1991) produced 60 eightway crosses, and each cross was made up of two parents from each CM.

Individual plants were selected in the $\mathrm{F}_{3}$ generation and a progeny was opened from each selected plant. The symbols adopted to represent the studied generations were $F_{4: 3[8]}, F_{5: 3[8]}$ and $F_{6: 3[8]}$. The $F_{4: 3[8]}$ progenies were classified in early, intermediate and 
semi-late maturity cycle; in the $F_{5: 3[8]}$ and $F_{6: 3[8]}$ generations, the progenies were regrouped in early CM (CMP), semi-early (CMSP), intermediate (CMI) and semi-late (CMST).

The $F_{4: 3[8]}$ generation experiment was carried out in a single locality during 1995/96 (ESALQ/USP experimental field), in the Federer augemented block design; each replication was stratified in experimental sets with common checks. Each plot was composed of two rows $5 \mathrm{~m}$ long and $0,5 \mathrm{~m}$ apart, and a space of $1 \mathrm{~m}$ was left between plots. The experiment was made up of a total of 715 progenies (229 of CMP, 350 of CMI and 136 of CMST). The $\mathrm{F}_{5: 3[8]}$ generation was carried out at two localities (ESALQ and Anhembi), and the $\mathrm{F}_{6: 3[8]}$ at three localities (ESALQ, Anhembi and Areão), both in randomized complet block designs with two replications, being each block stratified in experimental sets with common checks. The plots were composed of four rows $5 \mathrm{~m}$ long and $0,5 \mathrm{~m}$ apart. It was evaluated 310 progenies in $\mathrm{F}_{5: 3[8]}$ (17 of CMP, 60 of CMSP, 179 of CMI and 54 of CMST) and 127 in $\mathrm{F}_{6: 3[8]}$ (17 of CMP, 30 of CMSP, 60 of CMI and 20 of CMST). In the three generations, each set had four common and specific checks. The characters evaluated were : number of days to maturity (NDM), plant height at maturity (APM), lodging (Ac), agronomic value (VA), symptoms of soybean stem canker (CHS) disease and seed yield (PG).

Individual analysis showed significative genetic variability between progenies (eight-way crosses) for all characters, mainly in the intermediate cycle. Every maturity cycle showed greater genetic variability among progenies (eight-way crosses) than among checks (two-way crosses). The environmental effects were lower to agronomic value (VA) and soybean stem canker symptoms (CHS). In according to the agricultural year, the localities more or less efficients in separating the progenies. The localities were classified in the following order of efficiency: ESALQ, Anhembi and Areão. By increasing the larger number of agricultural years it was improved the separation of the progenies.

The genotype $\mathrm{x}$ locality $(\mathrm{G} \times \mathrm{L})$ interaction was more significant for $\mathrm{PG}$ and $\mathrm{Ac}$ in all maturity cycles (CM). The APM and CHS characters showed the lower estimates of $\mathrm{G} \times \mathrm{L}$. In relation to genotype $\mathrm{x}$ year $(\mathrm{G} \times \mathrm{A})$ interaction, it was obtained 20 
significative estimates among the 24 combinations of six characters and four maturity cycles. The triple interaction (genotype $\mathrm{x}$ locality $\mathrm{x}$ year) was more signicative for the progenies than checks on early, semi-early and intermediate cycle but the triple interaction was not significative in semi-late cycle. The stability analysis by ecovalence method was shown of easy and efficient application for evaluation of soybean genotypes, being observed a lot of progenies (eight-way crosses) more stable than the checks (two-way crosses) in all CM and for majority of the characters. The CMP progenies were less stable than those of CMSP, CMI and CMST.

In the selection for APM and VA, the character Ac must be considered. There was a tendency of positive correlation PG $x$ VA. In spite of the tendencies of positive correlations NDM $\times$ PG and NDM $\times$ CHS, there were progenies with superior PG and ausence of $\mathrm{CHS}$, in all $\mathrm{CM}$.

The progeny with the greatest stability and superior agronomic performance in each CM was: USP97-11.004 (early), USP97-11.030 (semi-early), USP97-11.097 (intermediate) and USP97-11.110 (semi-late). 


\section{INTRODUÇÃo}

A soja (Glycine max (L.) Merrill) é uma das principais culturas produtoras de grãos do mundo, além de ser a mais importante oleaginosa cultivada, tendo como principais produtos o óleo e o farelo de soja. A produção mundial estimada para a safra de 1998/99 é de 156 milhões de toneladas, o Brasil participando com cerca de 19\%. Devido a este montante, o Brasil atualmente é o segundo maior produtor mundial de soja, sendo superado apenas pelos Estados Unidos e seguido de Argentina, China e Índia. Dentro do pais, as maiores produções e áreas colhidas de soja em ordem decrescente encontram-se no sul, centro-oeste e sudeste respectivamente, apesar de ser cultivada em toda sua extensão. Esta ampla faixa de cultivo da cultura da soja, deve-se principalmente ao sucesso produtivo e adaptativo dos cultivares obtidos em programas de melhoramento genético visando vários aspectos da cultura (FNP Consultoria, 1999).

Nos programas de melhoramento para produtividade de grãos, têm surgido limitações principalmente devido à base genética estreita do material utilizado. Tal situação é decorrente do reduzido número de parentais empregados no desenvolvimento dos cultivares atualmente utilizados (cruzamentos biparentais), bem como do cultivo de grandes áreas com genótipos uniformes, levando ao estabelecimento de patamares de produtividade e vulnerabilidade a pragas, doenças e condições ambientais estressantes (Vello, 1992a). Estudos importantes sobre a base genética da soja têm sido realizados no Brasil (Hiromoto e Vello, 1986) e nos EUA (Gizlice et al., 1994).

$\mathrm{O}$ uso de cruzamentos múltiplos em programas de seleção recorrente surgiu recentemente, como alternativa na tentativa de resolver tal situação, pois promove a recombinação gênica entre vários parentais, fornecendo maior variabilidade e 
possibilidade de obter ganho genético para vários caracteres. Entende-se por cruzamentos múltiplos, aqueles que incluem mais de dois genótipos parentais de diferentes constituições gênicas. De acordo com Fehr (1987a), os cruzamentos múltiplos apresentam várias vantagens em relação aos cruzamentos simples (biparentais), destacando-se a presença na população de um número maior de alelos para cada loco e, consequentemente, uma oportunidade ampla para combinações epistáticas diferentes. Esta vantagem torna-se relevante quando se considera que a epistasia aditiva $\mathrm{x}$ aditiva responde por até $70 \%$ da variabilidade genética para produtividade de grãos (Hanson \& Weber, 1961,1962).

Conforme mencionado, o principal objetivo dos melhoristas tem sido desenvolver cultivares com grande potencial produtivo, porém um dos principais problemas enfrentados para a liberação e uso destes cultivares é o comportamento diferencial dos genótipos nos diferentes ambientes, denominado de interação genótipo $\mathrm{x}$ ambiente $(\mathrm{G} \times \mathrm{E})$. Além da especificidade a certos ambientes, a significância da interação $\mathrm{G} \times \mathrm{E}$ influencia o ganho com a seleção, pois dificulta a escolha dos genótipos favoráveis, sendo necessário optar por métodos específicos para avaliação e seleção (Brim, 1973). Para a soja em particular, ainda existem fatores ambientais altamente influenciáveis que mereceram vários estudos, tais como: temperatura, época de semeadura, pluviosidade, fotoperíodo, condições de solo. Os caracteres mais influenciáveis às variações de tais fatores ambientais são os de herança quantitativa, por exemplo altura de planta e produtividade de grãos.

Uma alternativa para minimizar estes efeitos seria o desenvolvimento de genótipos que possuissem performance superior, em um grande número de ambientes diferentes sob as mais diversas condições ambientais, e para o maior número possivel de caracteres de interesse, ou seja, que possuíssem estabilidade fenotípica.

Alguns estudos sugerem que, na grande maioria das situações, a sensibilidade do genótipo aos efeitos dos diferentes ambientes está ligada à sua base genética, sendo que, geralmente genótipos com ampla base genética ou maior variabilidade, possuem menor interação com o ambiente, dessa forma podendo ser mais estáveis (Allard, 1971; Allard \& Bradshaw, 1964). Dessa forma, o estudo da estabilidade fenotípica associada à 
variabilidade genética em soja, poderá ser útil para melhor compreensão e previsão do comportamento de certos genótipos em vários ambientes, quando se possui informações sobre a constituição genética dos mesmos.

Os objetivos do presente trabalho consistem em se avaliar a potencialidade de progênies obtidas a partir de cruzamentos óctuplos no programa de ampliação de base genética da soja, desenvolvido pelo Setor de Genética Aplicada às Espécies Autógamas, do Departamento de Génética da ESALQ/USP. O trabalho executado consistiu-se em uma parte de um ciclo de seleção recorrente, que é a estratégia principal do programa. As progênies foram agrupadas em diferentes ciclos de maturação (precoce, semiprecoce, intermediário e semi-tardio) e a seguir, efetuou-se estudos comparativos das progênies com genótipos oriundos de cruzamentos biparentais correspondentes às testemunhas específicas para cada ciclo de maturação. Avaliou-se vários caracteres como número de dias para maturidade, altura da planta na maturidade, acamamento, valor agronômico, reação ao cancro-da-haste da soja e produtividade de grãos. Outro grande objetivo do trabalho foi estimar o efeito da interação $G \times E$ relacionado ao desempenho das progênies para os caracteres avaliados, classificando-as quanto à magnitude da estabilidade fenotípica. Estudos complementares com médias, desvios padrões e correlações entre caracteres foram realizados de modo a facilitar a compreensão dos resultados obtidos e viabilizar a seleção para as próximas gerações. 


\section{REVISÃO DE LITERATURA}

\subsection{Caracterização e expansão da soja}

A soja [Glycine max (L.) Merrill] é uma espécie de ciclo anual, autógama, pertencente à familia Leguminosae. Apresenta $2 \mathrm{n}=40$ cromossomos, sendo reconhecida como um tetraplóide diploidizado (Van Raamsdonk, 1995), ou seja, um poliplóide com comportamento meiótico de um diplóide normal (Hymowitz et al., 1997).

Quanto ao seu centro de origem, fortes evidências apontam como mais provável local o leste da Ásia, sendo que sua domesticação ocorreu por volta do século XI a.C., na região nordeste da China. Na região Centro-Sul deste país está localizado o provável centro primário da espécie; a região da Manchúria representa o seu centro secundário de diversidade (Xu et al., 1989).

Da China, em 1765, a soja foi levada e introduzida nos Estados Unidos. A introdução da cultura no Brasil ocorreu na Bahia, por meio de sementes trazidas dos Estados Unidos. Posteriormente, em 1892, o cultivo difundiu-se para São Paulo, chegando ao Rio Grande do Sul em 1900. A partir daí, sua expansão foi rápida para outros estados do sul do Brasil, bem como de outras regiões, graças às condições favoráveis encontradas nestes locais, tanto para cultivo, quanto para mercado. Atualmente, devido ao grande sucesso alcançado nos programas de melhoramento da soja, esta cultura encontra-se presente nos campos de cultivo, do Rio Grande do Sul ao Maranhão e da Bahia ao Mato Grosso (Kiihl \& Almeida, 1992; Costa, 1996). 


\subsection{Melhoramento genético da soja}

Um breve histórico sobre o melhoramento da cultura da soja comportaria quatro fases bastante distintas e progressivas. A primeira, considerada como o primeiro método de melhoramento utilizado no Brasil, iniciado no século passado, é a introdução de cultivares e linhagens provenientes dos Estados Unidos, com maior adaptação às condições tropicais. Ainda dentro desta fase, ocorreram seleções de genótipos dentro de alguns cultivares, com características de interesse, ou mesmo mutantes naturais para caracteres que facilitaram a adaptação aos novos ambientes. A fase subsequente, iniciada por volta dos anos 40 deste século, constituiu-se na elaboração de cruzamentos entre dois parentais (cruzamentos biparentais), dos quais originaram-se importantes cultivares. A terceira fase, com início nos anos 70 , consistiu-se na elaboração de cruzamentos múltiplos, com mais de dois parentais, objetivando ampliar a base genética do germoplasma utilizado em programas que envolvem seleção recorrente e, paralelamente, desenvolver cultivares superiores, com elevação dos patamares de produtividade. A última fase deste processo teve início nos anos 80 com a implantação das modernas técnicas de engenharia genética e biotecnologia, presentes em projetos atuantes para a cultura (Vello, 1992b).

De acordo com Almeida \& Kiihl (1998), entre os principais aspectos visados em programas de melhoramento de soja estão o aumento de produtividade, precocidade, menor sensibilidade ao fotoperíodo (juvenilidade longa), melhoria da qualidade da soja alimento, resistência a pragas (complexo de percevejos, lagartas da soja) e resistência a doenças (cancro-da-haste da soja, nematóides de cisto e de galhas). O caráter que assume maior importância dentro dos programas, devido aos efeitos diretos, é a produtividade de grãos e, juntamente com esta característica, está a busca por cultivares que apresentem menor interação $\mathrm{G} \times \mathrm{E}$ ou maior estabilidade produtiva.

Enormes esforços têm sido realizados no sentido de se obter cultivares mais produtivas e estáveis, entretanto, existem algumas limitações como por exemplo a reduzida diversidade genética entre os atuais cultivares de soja que são utilizadas, muitas vezes, como parentais em programas de melhoramento. Tal fato, pode provocar o 
estreitamento da base genética da espécie, não permitindo a obtenção da variabilidade genética nos cruzamentos realizados, dificultando a obtenção de novas combinações genéticas e estabelecendo patamares de produtividade dificeis de serem superados.

Algumas alternativas podem ser utilizadas na tentativa de se ampliar a base genética em espécies autógamas, tais como: utilização de parentais geneticamente divergentes e com características desejadas; utilização de variedades tradicionais em cruzamentos múltiplos com linhagens elite melhoradas; sintetização de populações de ampla base genética, podendo-se fazer uso da machoesterilidade genética e conduzindoas por seleção recorrente e utilização de espécies selvagens (Rangel et al., 1996).

Conforme mencionado, uma alternativa para aumentar a variabilidade genética e ampliar a base genética, seria a introdução de germoplasma exótico. Entende-se por germoplasma exótico, todo material que ainda não contribuiu com genes aos cultivares utilizados em um dado ambiente, podendo ser então constituído por espécies, cultivares de outros locais ou países, raças, linhagens e pertencer ou não à mesma espécie que o material a ser melhorado (Vello, 1995).

\subsection{Utilização da seleção recorrente no melhoramento de soja}

A seleção recorrente é um método de melhoramento mais comumente utilizado em espécies alógamas do que em autógamas, principalmente devido à maior dificuldade que as autógamas apresentam para a na realização dos cruzamentos necessários para a recombinação em cada ciclo de seleção. O método consiste na obtenção de progênies, sua avaliação, seleção das melhores e intercruzamento das mesmas. A população obtida é submetida à avaliação e as melhores são novamente selecionadas e intercruzadas, formando-se ciclos sucessivos. Dessa forma, há mais chances de surgirem combinações genotípicas desejadas, aumentar a frequência de alelos favoráveis, além de favorecer a quebra de blocos gênicos e consequentemente o aumento de variabilidade em ciclos posteriores (Fehr, 1987b). Seu uso para as espécies autógamas, iniciou-se aproximadamente há duas décadas devido ao problema de reduzida variabilidade 
genética na maioria das espécies de autofecundação, sendo os seus resultados parciais promissores.

A preocupação com o aumento da variabilidade genética pode ser verificada através de alguns trabalhos realizados nos EUA e no Brasil.

Nos EUA, um estudo detalhado sobre a base genética dos cultivares americanos de soja que foram lançados entre os anos de 1947 e 1988 foi realizado por Gizlice et al. (1994), onde estes definem que base genética é o conjunto de genótipos contendo $99 \%$ dos genes encontrados em cultivares comerciais. Estabeleceram ainda, que a base genética seria definida com relação às plantas introduzidas (utilizadas como ancestrais nas hibridações), e as progênies oriundas das mesmas. Concluíram que $75 \%$ dos genes presentes nos cultivares modernos provinham das 17 primeiras linhagens lançadas antes de 1960 e que $95 \%$ desse total de genes eram oriundos de 28 ancestrais e sete progênies, totalizando 35 genótipos.

Trabalho semelhante foi realizado no Brasil por Hiromoto \& Vello (1986), onde 74 cultivares brasileiros de soja de origem híbrida recomendadas para cultivo entre 1983/84, foram estudados com o intuito de se medir a contribuição genética relativa das linhagens ancestrais. Pelo estudo, constatou-se que a base genética do germoplasma cultivado é estreita, onde somente 26 ancestrais são responsáveis pela genealogia dos cultivares brasileiros, e destes, apenas 11 são responsáveis por $89 \%$ do conjunto gênico total presente nestas cultivares. Entre os 11 ancestrais, seis deles também estão presentes nas genealogias dos cultivares norte-americanos. Os autores indicaram que a introdução de genótipos exóticos em cruzamentos nos programas de melhoramento pode ser uma alternativa para a ampliação da base genética do germoplasma cultivado, objetivando-se a superação de patamares de produtividade e evitando-se a possível ocorrência de vulnerabilidade genética a estresses biológicos e ambientais em campos de cultivo.

Um outro estudo foi realizado por Vello et al. (1988), com 69 cultivares de soja, onde se verificou que os coeficientes de parentesco entre eles variavam entre 0 e 1 . De acordo com a média geral $(f=0,16)$ dos 2346 coeficientes de parentesco obtidos, o programa de melhoramento de soja brasileiro seria considerado com tamanho efetivo 
baixo, pois apenas entre 11 a 15 diferentes genótipos teriam dado origem ao germoplasma cultivado.

Em outro trabalho, realizado nos EUA, algumas populações com base genética ampla foram obtidas a partir do cruzamento entre 40 introduções (PI) e outros 40 cultivares melhorados, com o intuito de se estudar a variabilidade genética e o potencial produtivo das mesmas. Para isto, através de diferentes tipos de retrocruzamentos, foram obtidas populações com $0 \%, 25 \%, 50 \%, 75 \%$ e $100 \%$ de PI's. Observou-se que a produtividade média diminuiu com o aumento da porcentagem de PI nas populações e que a população com $0 \%$ de PI apresentou cerca de metade da variabilidade genética das quatro populações contendo algumas porcentagens de PI. Torna-se muito provável então, que o uso limitado ( $25 \%$ de PI previamente selecionados para adaptação) de introduções na sintese de populações tenha resultados positivos com vários ciclos de seleção recorrente para produtividade de grãos, ou seja, a longo prazo (Vello et al., 1984).

A resposta à seleção recorrente depende dos caracteres que estão submetidos ao processo de seleção, da diversidade genética da população-base, do grau de influências ambientais na unidade de seleção e do tamanho da população.

Weber et al. (1990) fizeram testes com 2, 4, 8 e 16 parentais iniciais de soja, dos quais $1,2,4$, ou 8 cruzamentos foram feitos para iniciar o programa de seleção. Os mesmos números de parentais e cruzamentos foram utilizados para iniciar o próximo ciclo de seleção. Após 10,20 e 30 ciclos de seleção de um caráter, observou-se que a variabilidade genética não foi esgotada rapidamente, mesmo quando o número de parentais era muito pequeno, sendo que para uma resposta mais rápida, um número reduzido de parentais seria ideal, enquanto que para um programa a longo prazo, a variabilidade genética não se esgota até 10-20 ciclos. Outra conclusão é de que a principal vantagem do número maior de parentais é um maior grau de segurança para o programa e um maior número de cruzamentos pode reduzir o erro experimental.

Após três ciclos de seleção recorrente em soja para produtividade de grãos, Kenworthy \& Brim (1979) obtiveram aumentos efetivos na produtividade por ciclo, de $134 \pm 30 \mathrm{~kg} / \mathrm{ha} /$ ciclo na seleção entre progênies $S_{1}$, sugerindo assim, que este método 
pode ser usado para o desenvolvimento de populações de soja com maior variabilidade genética e altas médias de produtividade.

O potencial da seleção recorrente para incremento na produtividade de grãos em uma população de soja, foi avaliado por cinco ciclos sucessivos de seleção recorrente. A média de produtividade da população e das linhagens selecionadas para recombinação teve acréscimo de 17 e 54\%, respectivamente, quando comparados com um dos parentais originais. $\mathrm{O}$ ganho médio por ciclo foi de $128 \mathrm{~kg} / \mathrm{ha}$ ou $5,4 \%$ da produtividade da população-base (Rose et al.,1992).

Outro resultado satisfatório foi obtido por Sumarno \& Fehr (1982), onde obtiveram um aumento linear médio na produtividade de $120 \pm 10 \mathrm{~kg} / \mathrm{ha} /$ ciclo para os genótipos precoces estudados, $24 \pm 9 \mathrm{~kg} / \mathrm{ha} /$ ciclo para os genótipos de ciclo tardio e nenhum aumento significativo para os de ciclo intermediário. Para os outros caracteres estudados, como dias para maturidade, acamamento, altura da planta, peso de semente, porcentagem de óleo e proteína, não ocorreram mudanças significativas.

Vários métodos de seleção recorrente têm sido propostos para uso em soja, para diversos caracteres, como por exemplo a porcentagem de óleo nas sementes (Burton \& Brim, 1981), o peso médio de grão e o teor de proteína (Brim \& Burton, 1979; Burton, 1997). Outros trabalhos comparam as estimativas de ganho genético pela utilização de vários métodos de seleção recorrente (Uphoff et al., 1997), ou comparam o ganho genético de populações com diferentes percentagens de introduções de plantas em um mesmo programa de seleção recorrente (Ininda et al., 1996).

Para as espécies autógamas de modo geral, Goldringer et al. (1996) citam que a comparação teórica de métodos de seleção recorrente pode fornecer diretrizes para a escolha de uma melhor estratégia para a seleção. Para isso, compararam cinco metodologias: seleção em descendentes de duplo-haplóides com ciclos de 4 ou 5 anos, seleção entre famílias $S_{1}$, seleção entre bulk $S_{2}$ ou familias $S_{2}$, e seleção entre família de meio-irmãos ou irmãos-germanos. Os descendentes de duplo-haplóides com ciclo de 4 anos foram sempre mais eficientes, já na determinação dos parâmetros genéticos, este método foi seguido pelos descendentes de cinco anos e da seleção entre famílias $S_{2}$. 
Vários esquemas de intercruzamentos para síntese de populações-base para uso em programas de seleção recorrente foram comparados por Fatmi et al. (1992). Estudou-se os cruzamentos em cadeia, cruzamentos convergentes, cruzamentos dialélicos seguindo pares de cruzamentos e cruzamentos aos pares seguindo um dialelo. Foram avaliados a manutenção de alelos, o percentual de recombinação e a variabilidade genética disponível em cada população. Para os parâmetros avaliados, não houve diferença significativa entre os métodos, cabendo ao melhorista a escolha, de acordo com os recursos disponiveis para a sua implementação.

Parte de um programa de melhoramento de soja que vem sendo executado no Setor de Genética Aplicada às Espécies Autógamas do Departamento de Genética da ESALQ/USP, foi conduzido por Gomes (1995). O trabalho objetivou o estudo de 45 cruzamentos de soja em dialelo, nas gerações $F_{6: 3}$ e $F_{7: 6}$, visando a seleção de progênies superiores quanto à produtividade de grãos $(\mathrm{PG})$, além de comparar a eficiência da seleção para caracteres de interesse agronômico. Na geração $F_{6: 3}$ foram avaliados os cruzamentos "per se" e os 10 parentais e na geração $F_{7: 6}$, foram avaliadas 44 progênies dos 45 cruzamentos, totalizando 1980 progênies. Os caracteres avaliados foram números de dias para maturidade, altura da planta na maturidade, produtividade de grãos e valor agronômico. Alguns genótipos parentais com maior produtividade de grãos, participaram dos cruzamentos com maior número de progênies superiores. A ocorrência de segregantes transgressivos indicou a possibilidade da seleção de linhagens produtivas em todos os cruzamentos; além disso, as progênies podem ser selecionadas através do ciclo e, ou do valor agronômico, que são caracteres pouco influenciados pelo ambiente.

Com o intuito de avaliar a potencialidade de cruzamentos quádruplos de soja, para seleção de cruzamentos superiores em produtividade de grãos, Alliprandini (1996) avaliou as gerações $F_{2[4]}$ e $F_{3: 2[4]}$ de 45 populações oriundas de tais cruzamentos, pertencentes ao programa de seleção recorrente do Setor de Genética Aplicada às Espécies Autógamas do Departamento de Genética da ESALQ/USP. Os 20 parentais pertenciam a grupos de maturação semi-tardio e tardio e as progênies foram avaliadas para os caracteres número de dias para o florescimento e para a maturidade, altura da planta no florescimento e na maturidade, valor agronômico e produtividade de grãos. $\mathrm{O}$ 
autor encontrou que os parentais mostraram interação de genótipos $\mathrm{x}$ ambientes para ciclo (dias para o florescimento e maturidade), valor agronômico e produtividade de grãos; cruzamentos quádruplos entre parentais semi-tardios e tardios forneceram elevada variabilidade genética nas populações obtidas, produzindo segregantes superiores em valor agronômico e produtividade de grãos; para a maioria das populações, não houve redução de variabilidade entre as gerações estudadas.

Um estudo para verificar a potencialidade de 60 cruzamentos óctuplos de soja, oriundos de 40 parentais pertencentes a quatro grupos de maturação diferentes (precoce, semi-precoce, intermediário e tardio) foi realizado por Lopes (1996). Foi avaliada a geração $F_{1[8]}$, visando a seleção de cruzamentos superiores com ênfase na produtividade de grãos. Este trabalho faz parte do programa de seleção recorrente conduzido no Setor Genética Aplicada às Espécies Autógamas do Departamento de Genética da ESALQ/USP. Os caracteres avaliados foram número de dias para maturidade, altura da planta na maturidade, valor agronômico e produtividade de grãos. Neste estudo, o método dos cruzamentos óctuplos envolvendo quatro grupos de maturação, proporcionou elevada variabilidade genética na geração $F_{1[8]}$, originando segregantes superiores para os quatro caracteres avaliados.

Outro estudo para avaliação de 45 cruzamentos óctuplos em cadeia nas gerações $F_{4: 3[8]}$ e $F_{5: 3[8]}$ foi realizado por Hamawaki (1998). As progênies (precoces, intermediárias e tardias) foram avaliadas para altura da planta na maturidade, número de dias para maturidade, valor agronômico, produtividade de grãos, percentagem de óleo e produtividade de óleo. Quando comparadas às testemunhas, obteve-se progênies superiores oriundas de cruzamentos óctuplos para todos os caracteres, principalmente produtividade de grãos. Detectou-se também alta variabilidade genética entre progênies possibilitando a obtenção de ganhos genéticos em ciclos avançados de seleção.

As dificuldades existentes na execução dos cruzamentos, na fase de emasculação e polinização, além da grande demanda de tempo necessário, em espécies autógamas, torna o método muitas vezes dificil de ser executado, pois depende diretamente de mãode-obra especializada para tal fim. Pensando nisto, Brim \& Stuber (1973) propuseram o uso da machoesterilidade para obtenção de cruzamentos naturais em soja. 
O uso da machoesterilidade em programas de seleção recorrente mostrou-se muito útil no trabalho de Burton et al. (1990), devido à facilidade com que ocorre o intercruzamento entre as linhagens. Além disso, obtiveram uma aumento efetivo na produtividade de grãos em quatro ciclos de seleção, obtendo para duas populações um aumento de $76,6 \pm 23,8 \mathrm{~kg} / \mathrm{ha} /$ ciclo e $37,7 \pm 55,7 \mathrm{~kg} / \mathrm{ha} / \mathrm{ciclo}$. Para a primeira população, os resultados foram mais favoráveis, obtendo-se um ganho por ano de $2,1 \% \mathrm{em}$ produtividade de grãos; $5,9 \%$ de aumento na altura das plantas e uma redução de $8,9 \%$ para acamamento, durante os quatro ciclos avaliados.

Avaliando plantas $S_{0}$ e utilizando intercruzamentos facilitados por macho esterilidade, através de três critérios de seleção, Werner \& Wilcox (1990) alcançaram aumento na média de produtividade de $2,8 \pm 2,9 \mathrm{~g} /$ planta/ciclo em três ciclos de seleção recorrente a uma intensidade de seleção de $20 \%$. Tinius et al. (1991) encontraram um efeito indireto na produtividade a partir da seleção realizada para tamanho de sementes em plantas machoestéreis. Zhihong \& Junzheng (1991) realçaram a facilidade nos cruzamentos para programas de seleção recorrente, sugerindo a proporção no campo de 2:1 de macho-fértil para machoestéril, podendo ser dispostos alternados ou misturados nọ plantio.

No Brasil, os cruzamentos múltiplos ainda são pouco estudados, mas Alliprandini (1996) considera que a avaliação correta de parâmetros inerentes a cruzamentos múltiplos é de fundamental importância quando se objetiva estudar os mesmos em programas de seleção recorrente, bem como na ampliação da base genética do germoplasma utilizado.

Os principais programas de seleção recorrente para soja, estão sendo conduzidos nos EUA (lowa State University, University of North Carolina e University of Nebrasca; Weber et al., 1990), na Austrália (Rose et. al., 1992) e no Brasil (ESALQ/USP; Vello1992a).

Métodos de seleção recorrente têm sido propostos em soja, para vários caracteres, tais como, teor de óleo, peso médio de grão e teor de proteína (Burton, 1997), tamanho e composição de grãos (Tinius et al.1991; 1992; 1993), modificação do período reprodutivo (Hanson, 1992), dias para maturidade e teor de proteína (Xu \& Wilcox, 
1992). Outros trabalhos comparam as estimativas de ganho genético pela utilização de vários métodos de seleção recorrente (Uphoff et al., 1997), ou comparam o ganho genético de populações com diferentes percentagens de introduções de plantas em um mesmo programa de seleção recorrente (Ininda et al., 1996).

Outras espécies autógamas apresentam programas de seleção recorrente em andamento. Ilustrando tal fato, Goldringer \& Brabant (1993) realizaram uma extensa revisão bibliográfica de trabalhos realizados em vários países envolvendo cruzamentos múltiplos e a utilização de seleção recorrente. Um dos programas de seleção recorrente em autógamas que já se encontra em andamento é o programa de arroz do Brasil, realizado na EMBRAPA (Rangel et al, 1996); o programa de cevada (University of Minnesota - EUA); o programa de trigo (University of Minnesota; Kansas State University-EUA), o de feijão na Itália (Ranalli, 1996); e o programa de aveia dos EUA (Minnesota Agricultural Experimental Station; Dolan et al., 1996). Para este último, aumentos significativos de produtividade de $7,9 \%$ por ciclo ou $2,6 \%$ por ano através de cinco ciclos de seleção, foram obtidos (Pomeranke \& Stuthman, 1992). No programa de feijão (Ranalli, 1996), aumentos de produção por planta foram observados em dois ciclos sucessivos $\left(C_{0}\right.$ para $C_{1}$ e $C_{1}$ para $\left.C_{2}\right)$, principalmente devido a um aumento no número de vagens por planta, tendo também uma pequena contribuição no incremento do peso de 1000 sementes e no número de sementes por vagem.

Além das justificativas já citadas para programas de seleção recorrente, existem as de natureza teórica que incluem a obtenção de diversidade ao nível de alelos múltiplos e fixação epistática neste tipo de programa, originando a chamada variação "de novo". Os autores sugerem ainda, que esta variação pode ser oriunda de alguns mecanismos genéticos, tais como, amplificação gênica e elementos transposíveis, e que no final do processo, esta contribui significativamente para a diversidade do conjunto gênico obtido nos cruzamentos, em magnitude equivalente à diversidade genética original entre os diferentes parentais (Rasmusson \& Phillips, 1997). 


\subsection{Caracteres quantitativos}

Entende-se por caráter de herança quantitativa, aquele cujo controle é governado por vários pares de genes, podendo ser altamente influenciáveis pelas variações ambientais, fazendo com que estes caracteres apresentem uma distribuição contínua, ou seja, a ausência de classes definidas. Grande parte dos caracteres importantes para o melhoramento de soja possuem tal controle, tais como, produtividade de grãos, altura da planta, ciclo da cultura, tolerância à condições estressantes de solo.

Para um dado caráter quantitativo, em uma população segregante, é possivel verificar a manifestação da variação na sua expressão fenotípica, a qual pode ser devida a diferenças genotípicas e ambientais somadas. É de fundamental importância para o melhorista conhecer quanto desta variação é devida a diferenças genotípicas e ambientais, pois isso auxilia no processo seletivo, e na escolha do método mais adequado. Devido às dificuldades encontradas para obter tais informações, são utilizadas metodologias biométricas adequadas, as quais se fundamentam em procedimentos estatísticos tais como: obtenção de média, variância, covariância e seus respectivos componentes, além de correlação entre caracteres (Ramalho et al., 1993).

A herdabilidade é um caráter de grande importância, sendo definida como a porção da variância genética presente na variância fenotípica total, a qual inclui a variância ambiental. De acordo com Dashiell et al. (1994), a variação na magnitude da herdabilidade de um caráter, de um ambiente para o outro sugere, que os genótipos não se comportam da mesma forma em todos os ambientes avaliados, possivelmente devido à existência de interação genótipo $x$ ambiente. A herdabilidade estimada pode ser no sentido amplo, considerando toda a variância genética; ou no sentido restrito, considerando apenas a variância genética aditiva, que é fixada pela seleção. Devido à sua grande utilidade prática, a herdabilidade participa muitas vezes de fórmulas relacionadas à predição de ganho genético dos métodos de melhoramento utilizados.

Para melhores resultados nos programas de melhoramento, é necessário o conhecimento máximo do controle genético dos caracteres avaliados, sendo que alguns merecem atenção especial por parte do melhorista, dada a sua importância. 
Os caracteres dias para florescimento e dias para maturidade constituintes do ciclo da soja, são considerados de herança quantitativa, apesar de existirem genes principais controlando parte da sua expressão. São conhecidos seis pares de genes responsáveis por esta característica; em relação aos genes $E_{1} / e_{1}, E_{2} / e_{2}, E_{3} / e_{3}, E_{4} / e_{4} e$ $E_{5} / e_{5}$, identificados em trabalhos realizados em dias longos (Bernard, 1971; Buzzell, 1971; Buzzell \& Voldeng, 1980; Mc Blain \& Bernard, 1987), os alelos dominantes determinam florescimento e maturidade tardios; por outro lado, em condições de dias curtos, $\mathrm{o}$ alelo $\mathrm{E}_{6}$ para florescimento e maturidade precoces é dominante sobre o alelo $\mathrm{e}_{6}$ para florescimento tardio (Bonato \& Vello, 1999b). Em condições de dias curtos, realmente o florescimento tardio é condicionado por genes recessivos, tendo o número de genes envolvidos variado de um a três, conforme os genótipos utilizados (Toledo \& Kiihl, 1982; Bonato \& Vello 1999a). Para o caráter altura da planta, Caviness \& Prongsirivathana (1968) encontraram um gene principal atuante e alguns genes menores de efeitos modificadores.

O caráter valor agronômico constitui-se em uma medida subjetiva, avaliado através de uma escala de notas visuais, levando-se em conta, o potencial produtivo da planta, acamamento, altura, estado fitossanitário e aspecto visual. Alguns trabalhos têm utilizado tal medida como caráter auxiliar principalmente no processo seletivo de progênies de soja (Freire Filho,1988; Destro, 1991; Pacova, 1992; Gomes, 1995; LaínezMejía, 1996; Lopes, 1996; Rocha, 1998; Yokomizo, 1999; entre outros).

Vários trabalhos visando estimar a herdabilidade de tais caracteres têm sido realizados com a cultura da soja. Para número de dias de maturidade, as estimativas variaram de 75 a 95\% (Brim, 1973; Burton, 1987) e para herdabilidade no sentido amplo variou de 42 a 99\% (Chauhan \& Singh, 1984; Freire Filho, 1988; Destro, 1991). Para produtividade de grãos, as estimativas de herdabilidade no sentido amplo, variaram de 50 a 95\% (Chauhan \& Singh, 1984; Freire Filho, 1988), enquanto Destro (1991) encontrou estimativas próximas de $40 \%$ e Pacova (1992) um valor médio de $37 \%$; para a herdabilidade no sentido restrito, as estimativas foram de 13 a $58 \%$ (Weaver \& Wilcox, 1982; Pereira et al., 1984; Freire Filho, 1988). Para a altura da planta, utilizando-se herdabilidade no sentido amplo, foram obtidos valores entre 31 a $92 \%$ (Chauhan \& 
Singh, 1984; Freire Filho, 1988; Destro, 1991), e para herdabilidade no sentido restrito ficou entre 0-94\% (Caviness \& Prongsirivathana, 1968; Weaver \& Wilcox, 1982; Freire Filho, 1988; Bonato, 1989). Por último, para o caráter valor agronômico, os valores encontrados foram de $80 \%$ (Freire Filho, 1988) e 63\% (Pacova, 1992) para a herdabilidade no sentido amplo; já para a herdabilidade no sentido restrito, os valores encontrados foram de 29\% (Freire Filho, 1988) e 17\% em média (Pacova, 1992).

Um outro fator importante na herança de caracteres quantitativos em soja é a epistasia (St. Martin, 1981). A partição da variância genética de genótipos homozigóticos nos componentes aditivo e epistático aditivo $\mathrm{x}$ aditivo foi estabelecida (Hanson \& Weber, 1961; 1962 e Hanson et al., 1967). Cerca de $70 \%$ da variância genética para produtividade de grãos pôde ser atribuída a efeitos epistáticos.

Muitos estudos concluíram também que a variância genética aditiva, geralmente é o principal componente da variância genética total, em soja (Gates et al., 1960; Brim \& Cockerham, 1961; Singh et al., 1974; Freire Filho, 1988; Nass, 1989; Destro, 1991; Pinheiro, 1993). Esta consideração é importante para o melhoramento, pois, sendo a variância aditiva aquela transmitida de uma geração para outra, as médias das gerações estudadas permanecem constantes, como também é assegurada a transmissão da variância genética, melhorando a eficácia da seleção precoce.

Poucas estimativas de variância de dominância encontradas foram superiores às variâncias aditivas em alguns estudos com caracteres quantitativos (Leffel \& Hanson, 1961; Camacho, 1971; Pacova, 1992).

\subsection{Interação genótipo $x$ ambiente}

Nas etapas finais dos programas de melhoramento, geralmente, os testes são realizados em vários locais e anos. Nestas avaliações, pode-se observar que a maioria dos genótipos não se comportam de forma homogênea nos diversos ambientes avaliados. Quando isto ocorre, estamos diante da existência da interação genótipo $\mathrm{x}$ ambiente. Porém, a magnitude desta variação pode ser diferenciada de um genótipo para o outro, indicando que podem existir genótipos para ambientes particulares e genótipos com 
menores influências ambientais, ou seja, com ampla adaptação (Eberhart \& Russel, 1966). A existência da interação genótipo $x$ ambiente também causa a reduzida associação entre valores genotípicos e fenotípicos, sendo que interações de alta magnitude de significância podem reduzir os ganhos obtidos com a seleção (Comstock $\&$ Moll, 1963).

O comportamento diferencial dos genótipos frente a vários ambientes, tem sido tema de trabalho e preocupação de muitos melhoristas, pois a existência da interação genótipo $\mathrm{x}$ ambiente interfere na avaliação correta dos processos de seleção e nos seus resultados. Devido a este fato, é importante o conhecimento da estimativa da magnitude desta interação, bem como a utilização destes parâmetros para a determinação da estabilidade fenotípica dos diversos genótipos avaliados.

A maneira tradicional de se estimar a interação genótipo $\mathrm{x}$ ambiente é pela análise conjunta de variância, exemplificada em Gomes (1990). Desdobrando-se as somas de quadrados dos efeitos de ambientes e da interação genótipo $\mathrm{x}$ ambiente, obtém-se as somas de quadrados para os efeitos de ambientes para cada genótipo, o qual é utilizado para estimar a estabilidade daquele genótipo, sendo que quanto menor o valor da interação, mais estável será o genótipo. Através desta análise, a magnitude de todas as interações possíveis de serem estimadas, podem ser avaliadas de acordo com o propósito do melhorista.

$\mathrm{O}$ uso da análise de variância e de testes de hipóteses, como o $\mathrm{F}$, para verificar a significância ou não da interação genótipo $\mathrm{x}$ ambiente são de grande utilidade, porém não fornecem uma indicação adequada da resposta dos genótipos ou cultivares, aos diferentes ambientes testados, sendo necessárias outras análises complementares. Em termos biométricos, a variância da interação genótipo $\mathrm{x}$ ambiente, pode ser dividida em duas partes: simples e complexa; a primeira deve-se às diferenças na variabilidade genética existente entre os diferentes genótipos, dentro de locais; a segunda origina-se da falta de uma correlação linear perfeita entre os genótipos, de um ambiente para o outro, podendo impedir a seleção de genótipos promissores para vários ambientes simultaneamente (Vencovsky \& Barriga, 1992). O fato do comportamento superior de 
um genótipo num dado ambiente, não se repetir em outro ambiente testado, complica o trabalho de recomendação de cultivares por parte do melhorista (Ramalho et al., 1993).

Estas interações genótipo $\mathrm{x}$ ambiente podem apresentar diferentes naturezas: simples, quando não ocorrem mudanças no comportamento relativo dos genótipos entre ambientes; e complexa, quando o comportamento relativo dos genótipos é variável entre ambientes. As interações simples indicam a presença de genótipos adaptados a uma ampla faixa de ambientes, e as complexas indicam uma interação particular, ou seja, adaptação a um ambiente restrito (Vencovsky \& Barriga, 1992; Ramalho et al., 1993). De acordo com Cruz \& Castoldi (1991), a interação simples está relacionada à diferença de variabilidade entre genótipos, e a interação complexa à falta de correlação entre os mesmos. Quando a interação é atribuída ao segundo fator, segundo os autores, existe uma maior dificuldade no programa de melhoramento, já que isto indica a inconsistência da superioridade do genótipo com relação à variação ambiental, ou seja, existem genótipos com melhor desempenho em um ambiente mas não em outros, dificultando a recomendação ampla.

Com relação à ocorrência de variações ambientais, estas foram classificadas em previsíveis e imprevisíveis. As variações previsíveis são as características permanentes do ambiente como fertilidade do solo e fotoperiodo, além daquelas influenciáveis pelo homem, como data e densidade de plantio e outras práticas agronômicas. As variações imprevisiveis, ocorrem ao acaso, tais como, distribuição de chuvas, temperatura, ocorrência de pragas e doenças, dentre outras. Um estudo sobre a contribuição das variáveis climáticas à interação genótipo $\mathrm{x}$ ambiente em soja foi realizado por Kang et al. (1989).

Como a presença de interação genótipo $\mathrm{x}$ ambiente dificulta a recomendação de cultivares, algumas medidas podem ser utilizadas para que estes efeitos sejam minimizados (Ramalho et al.,1993): a identificação de cultivares específicas para cada ambiente, a realização de zoneamento ecológico e a identificação de cultivares com maior estabilidade fenotípica. A primeira medida é de dificil aplicação na prática, e a segunda é possível para diferenças macroambientais, fato que a torna vulnerável às variações imprevisiveis que possam ocorrer no ambiente. A terceira medida por sua vez, 
é a de maior eficácia, principalmente para culturas que são sensíveis às alterações climáticas (Arias, 1996), como a soja, que possui alta sensibilidade ao fotoperiodo.

$A$ ocorrência da interação genótipo $x$ ambiente é de elevada importância na determinação de alguns aspectos em programas de melhoramento, como : seleção para adaptação ampla ou específica; escolha dos locais para efetuar a seleção; nível de adversidade nos ambientes escolhidos para as fases iniciais de seleção; número ideal de ambientes e de genótipos avaliados em cada fase da seleção (Fox et al., 1997).

Um total de 897 progênies de soja precoces, intermediárias e tardias, das gerações $F_{6: 3}$ e 74 da geração $F_{7: 3}$ foram avaliadas por Laínez-Mejía (1996), com o intuito de estudar a magnitude da interação genótipo $\mathrm{x}$ ambiente, bem como a sua influência nos parâmetros genéticos e na seleção para produtividade de grãos e óleo. As progênies originaram-se de duas cadeias circulantes, envolvendo 40 parentais e 40 cruzamentos biparentais. Os caracteres avaliados foram : número de dias para a maturidade, altura da planta na maturidade, valor agronômico, teor de óleo nas sementes, produtividade de óleo e produtividade de grãos. Observou-se significância para a interação genótipo $\mathrm{x}$ ambiente para os caracteres produtividade de grãos e óleo, nas duas gerações, nos três ciclos de maturação. As progènies tardias, foram mais produtivas e mais afetadas pela interação genótipo $\mathrm{x}$ ambiente em ambas as gerações, sendo as precoces e intermediárias mais estáveis. A análise conjunta das duas gerações detectou diferenças entre épocas de cultivo mais evidentes que as diferenças entre locais.

Rocha (1998) avaliou 188 linhagens experimentais de soja de cruzamentos biparentais pertencentes a programa de seleção para grãos e óleo, dos grupos de maturação precoce, semi-precoce, intermediário e semi-tardio, com o objetivo de estudar a magnitude da interação genótipo $\mathrm{x}$ ambiente. Os ensaios foram conduzidos em três ambientes, sendo que para cada local, foram instalados quatro experimentos, correspondentes aos grupos de maturação. Os caracteres avaliados foram número de dias para maturidade, altura da planta na maturidade, acamamento, valor agronômico, porcentagem de óleo nas sementes, produtividade de óleo, reação ao cancro da haste e produtividade de grãos. Ocorreu significância da interação genótipo $\mathrm{x}$ ambiente para a maioria dos caracteres, evidenciando um comportamento diferencial das linhagens nos 
locais de teste. Porém, para teor de óleo (grupo precoce e intermediário) e acamamento (grupo intermediário), observou-se ausência de interação. Uma maior variabilidade entre as linhagens dentro dos ciclos de maturação foi observada para os caracteres altura da planta, produtividade de grãos, valor agronômico e teor de óleo, indicando maiores possibilidades de ganhos com a seleção.

Dados de produtividade foram coletados em linhagens de soja dos grupos de maturação III e IV, em 14 ambientes. As linhagens em cada grupo de maturação foram separadas de acordo com as médias de produtividade para todos os ambientes em três níveis distintos (alta, média e baixa produtividade). Concluíram que o nível de produtividade do ambiente não influenciou a classificação das linhagens. No grupo de maturação III, os genótipos menos produtivos contribuiram mais para a variância da interação, seguidos pelos de média e alta produtividade, respectivamente. $\mathrm{O}$ mesmo ocorreu para o grupo IV, porém neste, os genótipos de média e alta produtividade, tiveram contribuições similares para a interação. Assim, é possivel identificar uma grande parte dos genótipos de alta produtividade, ainda que na presença de interação genótipo x ambiente (Scott et al., 1994). Em um trabalho anterior, Adegoke \& Frey (1987), em aveia, encontraram que os genótipos mais produtivos tiveram uma maior proporção para a interação do que os genótipos de média e baixa produtividade.

Genótipos de soja e suas interações com o ambiente foram estudados por Alliprandini et al. (1994), no estado do Paraná, Brasil. Os genótipos foram reunidos em grupos de maturação precoce, semi-precoce e médio. Os resultados evidenciaram que a produtividade foi muito influenciada pelo ambiente, tornando-se tal fato claro pela significância da interação genótipo x local. As interações ano $\mathrm{x}$ local, significativas em todos os grupos de maturação, indicaram que os testes devem ser realizados em vários locais dentro do estado avaliado, podendo em contrapartida, serem abreviados para um ano, pela não-significância desta fonte.

Estudo realizado por Sakiyama et al. (1988) no Estado de Minas Gerais, também no Brasil, com 16 genótipos de soja avaliados em 43 ensaios experimentais, em 16 ambientes, em dois anos agrícolas, avaliou somente os nove genótipos comuns a todos os ensaios. O objetivo do trabalho foi avaliar a eficiência da seleção dos genótipos de 
soja nestas condições, com a seleção realizada em duas localidades adequadamente escolhidas e três épocas diferentes de semeadura. Encontraram que a seleção dos genótipos quanto à produtividade de grãos, adaptabilidade e estabilidade fenotípica, pode ser realizada em ambas as condições. Isso facilita a execução do programa e reduz os custos necessários para condução de ensaios em diferentes localidades.

Outro estudo comparando a magnitude da interação genótipo $\mathrm{x}$ ambiente em 32 linhagens do grupo precoce de soja foi realizado por Pfeiffer, et al. (1995) nos Estados de Kentucky e Minnesota, nos Estados Unidos. Os genótipos foram avaliados em quatro ambientes, em ambos os estados, e os caracteres avaliados foram produtividade de grãos e concentração de óleo e proteína nas sementes. Para o caráter produtividade de grãos, as interações genótipo $\mathrm{x}$ ambiente dentro dos estados foram significativas em ambos, ao passo que a interação genótipo $\mathrm{x}$ estado não foi significante. As interações dentro e entre estados foram todas significativas para os caracteres concentração de óleo e proteína nas sementes.

Uma análise de agrupamento foi realizada por Ivory et al. (1991) com seis linhagens de soja em 19 ambientes na Tailândia, com o objetivo principal de avaliar a performance genotípica, identificar e agrupar genótipos com padrões similares de resposta quanto à produtividade em diversos ambientes. $O$ uso de desvios de produtividade do genótipo em relação à média ambiental de produtividade como uma medida do efeito da interação genótipo $\mathrm{x}$ ambiente mostrou-se efetivo na diferenciação das linhagens aos ambientes avaliados, facilitando a recomendação para regiões particulares.

Em trabalho realizado por Maestri et al. (1998).na Argentina, com o propósito de estudar a influência do ambiente em alguns parâmetros químicos de sementes de soja, 12 linhagens dos grupos de maturação IV a VI foram testadas em quatro ambientes. O conteúdo de óleo e proteína variou de 329 a $436 \mathrm{~g} / \mathrm{kg}$ e de 198 a $267 \mathrm{~g} / \mathrm{kg}$, respectivamente. $\mathrm{O}$ teor de ácidos graxos saturados foi constante para as regiões avaliadas, enquanto o teor de ácidos insaturados variou significativamente entre os diversos ambientes. Ocorreram diferenças significativas entre as linhagens testadas, mas nenhuma interação genótipo $\mathrm{x}$ ambiente importante foi detectada. Os resultados obtidos 
são de grande importância, principalmente em programas que visam a obtenção de novos genótipos de soja com melhor qualidade de óleo nas sementes.

Através da avaliação de sete genótipos de soja na Austrália, em várias épocas de semeadura, Rose (1987) concluiu que variações na produtividade de grãos foram afetadas pelas datas de semeadura, pelos genótipos, e pela interação genótipo $\mathrm{x}$ data de semeadura. $\mathrm{O}$ efeito das datas de semeadura não foi significativo para o caráter peso de sementes, sendo que a semeadura tardia diminuiu significativamente a porcentagem de óleo nas sementes em 1,7\%. Toledo et al. $(1993,1994)$ também avaliaram vários genótipos de soja em diferentes épocas de semeadura, com o objetivo de avaliar a resposta ao fotoperíodo bem como o mecanismo genético que governa tal resposta. Detectaram significância na interação genótipo $\mathrm{x}$ ambiente, para a resposta ao fotoperiodo.

Os efeitos ambientais e da interação genótipo $\mathrm{x}$ ambiente também foram avaliados para caracteres de qualidade de linhagens de soja do grupo natto (produto fermentado obtido a partir de genótipos de soja com sementes pequenas ou com menos de $10 \mathrm{~g} / 100$ sementes), no Canadá, por Cober et al. (1997). A melhoria de caracteres relacionados à qualidade deste tipo de soja é importante para a manutenção e expansão deste mercado. Um grupo de sete linhagens (grupo 1) foi avaliado em cinco locais e dois anos agrícolas (1989 e 1990); um outro conjunto de 15 linhagens (grupo 2) também foi avaliado nos mesmos cinco locais, porém em 1993 e 1994. Caracteres importantes para este grupo de soja foram avaliados, tais como, fração de sementes pequenas, porcentagem de sementes com tegumento impermeável, embebecimento, formato da semente e níveis dos componentes da semente (cálcio, óleo e açúcar). Os genótipos diferiram entre si para a maioria dos caracteres nos dois conjuntos de genótipos; os efeitos de locais foram não-significativos para todos os caracteres e os efeitos de anos foram significativos somente para formato de semente e nível de açúcar no segundo conjunto. As interações ano $\mathrm{x}$ local e genótipo $\mathrm{x}$ ambiente foram frequentemente significativas, porém os componentes de variância desta segunda interação tiveram menor magnitude que os efeitos principais do genótipo, indicando que é possível desenvolver cultivares adaptadas a uma faixa ampla de ambientes. 


\subsection{Estabilidade fenotípica em soja}

Embora os termos estabilidade e adaptabilidade, muitas vezes sejam utilizados com o mesmo objetivo, estes possuem diferenças. Mariotti et al. (1976) consideram a adaptabilidade como a capacidade dos genótipos de aproveitarem vantajosamente 0 estímulo do ambiente, sendo esta uma vantagem sob o ponto de vista produtivo; e a estabilidade, segundo Cruz \& Regazzi (1994), é definida como a capacidade dos genótipos expressarem um comportamento altamente previsível em função da qualidade do estímulo ambiental. Este conceito tem obtido grande aceitação atualmente.

Para culturas autógamas como a soja, uma maior estabilidade produtiva ou menor interação genótipo $\mathrm{x}$ ambiente, pode ser obtida, através do aumento da variabilidade genética, podendo ser por mistura de genótipos ou cultivo de multilinhas (Allard \& Bradshaw, 1964; Marshall \& Brown, 1973).

Atualmente, existem várias metodologias para se realizar análises de estabilidade, tendo todas a finalidade de avaliar um grupo de genótipos testados em vários ambientes. Todas as metodologias possuem como princípio a existência de interação genótipo $\mathrm{x}$ ambiente, distinguindo-se quanto aos conceitos de estabilidade adotados e princípios estatísticos empregados. Alguns métodos serão destacados, devido ao seu uso intenso em trabalhos de estimativa de estabilidade de culturas importantes.

Entre os métodos que utilizam a análise de regressão linear destacam-se as metodologias de Eberhart \& Russel (1966) e de Silva \& Barreto (1985), modificada por Cruz et al. (1989). Na primeira, o genótipo ideal é aquele que apresenta produção média alta, coeficiente de regressão igual a $1,0(\beta=1)$ e desvio da regressão $\left(\mathrm{s}_{\mathrm{d}}{ }_{\mathrm{d}}\right)$ nulo ou o menor possivel. Assim, o genótipo ideal deve apresentar resposta positiva à melhoria das condições ambientais $(\beta=1)$, tendo adaptabilidade geral, e um comportamento altamente previsível $\left(\mathrm{s}_{\mathrm{d}}{ }_{\mathrm{d}}=0\right)$. Na segunda metodologia, os parâmetros de adaptabilidade são : a média, a resposta linear aos ambientes desfavoráveis $\left(\beta_{1 i}\right)$ e aos ambientes favoráveis $\left(\beta_{1 \mathrm{i}}+\beta_{2 \mathrm{i}}\right)$. O parâmetro principal de estabilidade é o desvio da regressão $\left(\mathrm{s}^{2} \mathrm{~d}\right)$, auxiliado pelo coeficiente de determinação $\left(\mathrm{R}^{2}\right)$ para seleção e descarte dos genótipos, sendo que 
os genótipos que possuírem $\mathrm{R}^{2}$ acima de $80 \%$, mesmo com desvios de regressão significativos, podem ser selecionados (Cruz \& Regazzi, 1994).

Entre as metodologias que utilizam análise multivariada, destaca-se o AMMI (Additive Main Effects and Multiplicative Interaction) ou modelo de efeitos aditivos e interação multiplicativa. Este modelo baseia-se inicialmente em se estimar os efeitos médios aditivos de genótipos e de ambientes através de uma análise de variância comum e, posteriormente, são calculados os efeitos multiplicativos para a interação genótipo $\mathrm{x}$ ambiente pela análise de componentes principais (Zobel et al., 1988; Crossa, 1990; Sneller \& Dombek, 1995; Annicchiarico, 1997).

Existem ainda outros métodos que não utilizam a regressão linear, nem a metodologia de análise multivariada. A análise destas metodologias torna-se um pouco mais simplificada e entre eles podemos citar o método de Wricke (1965), citado por Oliveira (1976). Este método possui como principal parâmetro, a "ecovalência", que se baseia na decomposição da interação genótipo $\mathrm{x}$ ambiente, em componentes atribuídos a cada genótipo. A "ecovalência" avalia as oscilações de cada genótipo frente às variações ambientais, sendo o genótipo tanto mais estável quanto menor for o valor deste parâmetro, ou seja, quanto maior for a contribuição do genótipo para a interação, maior será a ecovalência e menos estável será o genótipo.

De acordo com Fuchs (1979), para que tais estimativas de "ecovalência" sejam representativas, é necessário avaliar os genótipos em três ou quatro anos; um maior número de repetições em vários locais talvez seja mais eficaz para a estimativa da ecovalência do que o uso de repetições em vários anos. Yue et al.(1997) também observaram que a avaliação dos testes em apenas um ano não fornece estimativas confiáveis, necessitando de mais de um ano de avaliação. Uma das características importantes do método é o fato de permitir a avaliação de um pequeno grupo de genótipos, sem perda da eficiência. Outras métodologias também utilizam o efeito da interação genótipo x ambiente para estudo da estabilidade fenotípica, entre eles, o de Eberhart \& Russel (1966), Shukla (1972) e Tai (1971).

Comparações entre as várias metodologias existentes para análise de estabilidade, têm sido realizadas em soja (Zobel et al., 1988; Sneller et al., 1997) e 
outras culturas (Duarte, 1988; Duarte \& Zimmermann, 1995; Arias, 1996; Raizer, 1998). De acordo com Duarte (1988), métodos que se baseiam em parâmetros únicos, como o método de Wricke (1965), fornecem pouco conteúdo informativo, oferecendo pouca segurança na recomendação de cultivares, quando comparados àqueles que utilizam regressão linear (Finlay \& Wilkinson, 1963; Eberhart \& Russel, 1966; Silva \& Barreto, 1985). Porém, Carvalho (1983) obteve resultados indicando que o teste de Wricke (1965) apresentou resultados similares aos obtidos pelos métodos de Eberhart \& Russel (1966) e Tai (1971). Neste trabalho, o autor avaliou a produtividade de progênies de trigo, comparando as três metodologias citadas e encontrou que em todas elas, os genótipos mais produtivos eram os menos estáveis.

Raizer (1998) utilizou cinco metodologias para estimativa de estabilidade em análise de 48 clones de cana-de-açúcar comparadas com oito variedades comerciais. Os ensaios foram realizados no Estado de São Paulo e os caracteres avaliados foram produtividade de colmos, teor de sacarose dos colmos e produtividade de açúcar. Para estimativa de estabilidade fenotípica, obteve-se melhores resultados para as metodologias de Roemer e Wricke, sendo que estas devem ser utilizadas em conjunto com a produtividade de açúcar para a seleção de clones.

Trabalhando com a cultura da soja, Yue et al. (1997) compararam as metodologias de Eberhart \& Russel (1966), Tai (1971), Shukla (1972) e Wricke (1965), para estimativa de parâmetros de estabilidade de 12 cultivares de soja em dez ambientes avaliados. As metodologias utilizadas apresentaram correlações positivas e significativas, indicando que os métodos comportaram se de formas similares no fornecimento das estimativas de estabilidade para os genótipos testados, e também que cultivares altamente produtivos podem apresentar alta estabilidade. Outros trabalhos (Vega, 1984; Yue et al., 1996) concordaram com estes resultados.

Yokomizo (1999) avaliou 24 progênies $F_{9: 4}$ oriundas de 15 topocruzamentos de soja tipo alimento para seleção como hortaliça, doce e salada, em três ambientes [Piracicaba-verão (PV), Piracicaba-outono (PU) e Anhembi-verão (AV)] e duas épocas de semeadura. Os principais objetivos foram: verificar o efeito da interação genótipo $x$ ambiente e estimar a estabilidade fenotípica das progênies. Os caracteres avaliados 
foram : número de dias para a maturidade, altura da planta na maturidade, acamamento, valor agronômico, largura visual das vagens, peso de cem sementes e produtividade de grãos. Pelos resultados, foi possível obter progênies precoces mesmo com parental tardio envolvido no cruzamento; a seleção para maior altura deve estar associada ao acamamento; PV discriminou melhor as progênies para altura, largura de vagens e produtividade de grãos; PU discriminou para todos os caracteres, exceto acamamento; AV foi intermediário em discriminar as progênies. $O$ método da ecovalência foi mais eficiente que o uso do teste de Scott-Knott e do histograma juntos, para medir a estabilidade das progênies; a seleção baseada na estabilidade e nas médias dos caracteres para soja alimento foi eficaz para obtenção de novos genótipos para o objetivo especificado.

Algumas metodologias para estimação em soja, foram comparadas utilizando-se derivações do modelo AMMI e regressão linear. Todas as metodologias testadas detectaram diferenças significativas entre os genótipos testados, porém a repetibilidade das classificações dos genótipos nos diferentes períodos avaliados, foi relativamente baixa (Sneller et al.,1997).

Vários caracteres podem ser submetidos ao estudo de adaptabilidade e estabilidade, entre estes, a produtividade de grãos é o que concentra o maior número de trabalhos com soja em várias regiões do Brasil (Duarte et al., 1994; Galvão, 1994; Rubin, 1996), e em outros países (Bhatnagar \& Karmakar, 1993; Scott et al., 1994; Deka \& Talukdar, 1997). Porém, outros caracteres como conteúdo de proteina e de óleo também são contemplados (Pazdernik et al., 1997; Raut et al., 1997).

A capacidade produtiva de genótipos de soja em diferentes grupos de maturação (precoce, intermediário e tardio), foi avaliada Duarte et al. (1994) quanto a sua adaptabilidade e estabilidade pelo método de regressão linear segmentada de Silva \& Barreto (1985), nas condições de Goiás e Distrito Federal; tal método permite avaliar as respostas produtivas de cada genótipo em ambientes abaixo e acima da média geral. Apenas $14 \%$ dos genótipos não tiveram seus comportamentos plenamente explicados pelo método, indicando um ajuste adequado aos dados. A produtividade e estabilidade 
foram prioritárias em relação à adaptabilidade e os genótipos promissores dentro de cada grupo de maturação puderam ser identificados.

O comportamento quanto à estabilidade de 21 genótipos de soja foi analisado por Deka, \& Talukdar (1997) pela metodologia de Eberhart \& Russel (1966), em cinco locais diferentes na Índia. Os caracteres avaliados foram número de dias para maturidade, número de vagens por planta, número de sementes por vagem, peso de cem sementes e produtividade por planta. Foi detectada significância da interação genótipo $x$ ambiente para a maioria dos caracteres, sendo que a metodologia foi eficiente na discriminação dos genótipos, estabelecendo uma classificação e mostrando aqueles que se comportaram na média ou acima desta, principalmente quanto à produtividade de grãos.

Estimativas de parâmetros de estabilidade de dez genótipos de soja, foram obtidos na Índia por Raut et al. (1997), em condições irrigadas e de sequeiro, em três locais. Os caracteres avaliados foram número de dias para florescimento, número de dias para maturidade, altura da planta, número de vagens por planta, peso de cem sementes, teor de óleo e produtividade de grãos. Foram realizadas análise conjunta de variância e estimativa de estabilidade pela metodologia de Eberhart \& Russel (1966). Para todos os caracteres, observou-se significância na interação genótipo $\mathrm{x}$ ambiente, bem como alta discriminação dos genótipos, principalmente para produtividade de grãos e teor de óleo.

Pazdernik et al. (1997) avaliaram 30 cultivares de soja em 15 ambientes diferentes na região de Minnesota, nos Estados Unidos. Os caracteres avaliados foram produtividade de grãos, teor de proteína e de óleo. Os parâmetros de estabilidade foram estimados por três metodologias, sendo que nas análises conjuntas para todos os caracteres, todas as interações envolvendo cultivares e locais ou anos, foram significativas, dentro de cada zona de cultivo. Os resultados sugeriram que a análise de estabilidade associada à observação de médias, pode ser útil na recomendação de cultivares, tendo uma ótima eficácia para produtividade de grãos e teor de proteína.

Em estudos de estabilidade da reação a doenças, uma avaliação de diferentes isolados do fungo causador do cancro-da-haste (Diaphorte phaseolorum f.sp. meridionalis) foi realizada por Pereira et al. (1996) através das características vigor da 
planta e extensão da lesão, em nove cultivares de soja em Minas Gerais. Foram realizadas avaliações aos $10,20,30$ e 40 dias após a inoculação. Os resultados indicaram que os cultivares que apresentaram maior estabilidade tenderam a ser os mais resistentes à infecção pelo cancro-da-haste, e os de maior suscetibilidade, os mais instáveis. Por outro lado, os isolados mais estáveis tenderam a ser os menos agressivos, enquanto os mais instáveis mostraram comportamento variado, desde moderada até altamente agressivos aos cultivares.

Cultivares de hábito de crescimento do tipo determinado, semi-determinado e indeterminado diferem entre si quanto ao término do crescimento do ramo principal. Este fato afeta indiretamente a altura da planta, a resistência ao acamamento e os comprimentos dos períodos de florescimento e reprodutivo. Estudos prévios em soja indicaram que cultivares de hábito de crescimento semi-determinado devem possuir menor estabilidade quanto à produtividade, relativamente ao tipo indeterminado. Para confirmação de tais afirmativas, Ablett et al. (1994) comparou 40 linhagens de soja destes dois tipos de crescimento, em nove ambientes para produtividade de grãos e altura da planta. As interações genótipo $\mathrm{x}$ ambiente foram significativas e de magnitude similar para os dois tipos de hábito de crescimento e a análise de estabilidade detectou linhagens estáveis para produtividade de grãos em ambos os grupos, concluindo que a estabilidade não se constitui em barreira para o melhoramento de linhagens com hábito semi-determinado.

Estimativas de parâmetros de estabilidade também foram obtidas para soja vegetal ou alimento (Mebrahtu \& Elmi, 1997) por métodos de regressão linear. Além disso, Schnebly \& Fehr (1993) estudaram a estabilidade da composição de ácidos graxos no óleo das sementes de soja, em vários ambientes e várias datas de semeadura.

\subsection{Correlações entre caracteres}

A associação existente entre diferentes caracteres para uma espécie é de fundamental importância para os programas de melhoramento, visto que, na elaboração dos mesmos não se objetiva aprimorar um único caráter favorável mas, um conjunto 
deles (Vencovsky \& Barriga, 1992). Por definição, a correlação é uma medida do grau ou magnitude de associação, existente entre dois caracteres. De acordo com Wright (1921), o coeficiente de correlação parte do ponto de existência de uma relação linear entre duas variáveis, ou seja, a alteração de uma variável provocará uma alteração aproximadamente constante no valor médio da outra variável. E segundo Ramalho et al. (1993), a correlação é estimada de modo a permitir ao melhorista o conhecimento das mudanças que ocorrem em um caráter quando se realiza a seleção em outro caráter a ele correlacionado.

A correlação existente entre caracteres, que é medida ou visualizada em um experimento é a fenotípica. Esta, no entanto, é influenciada por dois fatores: genéticos e ambientais. Sendo assim, pode-se ter correlações de natureza fenotípica, genética e ambiental. Para o melhoramento, a correlação de maior interesse é a genética, devido a sua natureza herdável (Vencovsky \& Barriga, 1992).

A existência de correlação genética entre dois caracteres é devida ao efeito pleiotrópico ou de ligação entre os genes responsáveis por tais caracteristicas. Para a correlação genética oriunda de efeitos pleiotrópicos, ela assume caráter permanente, expressando a quantidade pela qual duas características são influenciadas pelos mesmos genes e o efeito total de todos os genes em segregação, que afetam as duas características. As correlações existentes entre caracteres podem ser positivas ou negativas. Quando os genes responsáveis aumentam (ou diminuem) o valor fenotípico dos dois caracteres correlacionados, dizem-se que a correlação é positiva. Por outro lado, se os genes aumentam o valor fenotípico de um caráter e reduzem a expressão de outro caráter, dize-se que a correlação é negativa (Ramalho et al., 1993). A seleção para caracteres de correlação negativa pode representar problemas se ambos forem desejáveis, uma vez que a seleção para aumento de um caráter implicará na diminuição do outro negativamente correlacionado. A correlação positiva, por outro lado, não enfrenta tais dificuldades, pois, se ambos forem desejáveis, quando a seleção aumentar o valor de um, acontecerá o mesmo para o outro.

Com relação à correlação ambiental, ela existe quando dois caracteres são influenciados da mesma forma por fatores ambientais. Contudo, este coeficiente de 
correlação, pode não representar exatamente o efeito devido aos fatores ambientais, uma vez que os componentes de variância e covariância relacionados ao resíduo podem incluir também os efeitos de dominância, de epistasia e da interação genótipos $\mathrm{x}$ ambientes (Silva, 1982).

Espera-se que as correlações genéticas e ambientais sejam ambas positivas ou negativas para dois caracteres analizados. Se isto não ocorreu, significa que as causas da variação genética e ambiental influenciaram os caracteres através de diferentes mecanismos fisiológicos (Falconer, 1987).

Em soja, as estimativas de correlações genotípicas foram geralmente maiores que as fenotípicas, sendo que alguns caracteres de grande importância econômica e para o melhoramento foram contemplados nestes estudos (Weber \& Moorthy, 1952; Anand \& Torrie, 1963; Freire Filho, 1988; Pacova, 1992; Pinheiro, 1993; Yokomizo, 1994; Santos, 1994; Gomes, 1995; Alliprandini, 1996; Lopes, 1996; Pinheiro, 1998; Yokomizo, 1999). Entre tais caracteres estudados pode-se citar: produtividade de grãos, altura da planta, número de dias para maturidade, tamanho de semente, tamanho de vagem, valor agronômico, acamamento e teores de óleo e proteína.

Correlações positivas entre os caracteres produtividade de grãos e altura da planta foram obtidas em vários trabalhos (Weber \& Moorthy,1952; Anand \& Torrie, 1963; Bays, 1975; Montenegro, 1994; Prado, 1994; Santos, 1994; Gomes, 1995; Lopes, 1996; Pinheiro, 1998; Yokomizo, 1999). Algumas correlações encontradas foram maiores que 0,4 (Gomes, 1995); variaram de 0,2 a 0,5 (Lopes, 1996); foram próximas de 0,7 (Pinheiro, 1998) ou situaram-se entre 0,5 a 0,8 (Yokomizo, 1999).

Para os caracteres produtividade de grãos e número de dias para maturidade foram observados valores positivos maiores que 0,4 (Gomes, 1995; Lopes, 1996). Outros valores também foram detectados entre eles: 0,7 por Pinheiro (1998) e valores entre 0,2 e 0,8 por Yokomizo (1999). Tais valores foram concordandes com aqueles encontrados por Weber \& Morthy (1952); Anand \& Torrie (1963); Monteverde (1984); Pacova (1992); Santos (1994); Montenegro (1994) e Prado (1994). As correlações obtidas ao nivel de parcela foram mais consistentes do que aquelas tomadas ao nível de plantas individuais, nos trabalhos citados. Por outro lado, algumas correlações negativas 
de produtividade de grãos com número de dias para a maturidade e altura da planta também foram detectadas (Montenegro, 1994; Prado, 1994).

A produtividade de grãos também foi correlacionada positivamente com o caráter valor agronômico. Gomes (1995) encontrou valores entre 0,77 e 0,92 , ao passo que Alliprandini (1996) detectou valores maiores que 0,6. Lopes (1996) encontrou valores situados entre 0,5 a 0,7; e para Pinheiro (1998) e Yokomizo (1999), os valores obtidos superaram 0,6 , sendo que para o último, a maioria das estimativas aproximaram-se do valor 1,0 .

Número de dias para a maturidade e valor agronômico possuem na grande maioria dos trabalhos correlações positivas e altas. Geralmente, valores maiores que 0,4 foram encontrados (Gomes, 1995; Alliprandini, 1996; Lopes, 1996; Pinheiro, 1998; Yokomizo, 1999). Destaca-se a correlação entre tais caracteres encontrada por Alliprandini (1996) no valor de 0,91.

A correlação entre o número de dias para a maturidade e a altura da planta, também se comportou similarmente à situação anterior. Resultados superiores a 0,4 foram detectados por Lopes (1996); maiores que 0,7 por Gomes (1995) e Alliprandini (1996); e resultados entre 0,7 e 0,8 por Pinheiro (1998) e Yokomizo (1999).

A altura da planta parece estar correlacionada positivamente também com o caráter valor agronômico, sendo que os valores de correlação encontrados situaram-se entre 0,6 e 0,9 (Gomes, 1995) ou entre 0,4 e 0,8 (Lopes, 1996), ou, outras vezes superando 0,7 (Pinheiro, 1998; Yokomizo, 1999). Valores baixos positivos e negativos $(-0,19$ a 0,19$)$, foram obtidos nos estudos realizados por Freire Filho (1988).

Para o caráter acamamento, Yokomizo (1999) também efetuou um estudo de correlação fenotípica e genética, com vários outros caracteres de interesse econômico para a soja. Os valores encontrados para a correlação genética entre acamamento e valor agronômico foram positivos e maiores ou iguais a 0,6. Apesar de se esperar valores negativos, os valores encontrados podem ser devidos a pequena diferença entre as médias dos dois caracteres. Para a correlação com altura da planta, foram obtidos valores altos e positivos (em torno de 0,9 ), conforme o esperado, já que plantas maiores tendem a um maior acamamento. A correlação com produtividade de grãos também foi positiva 
$(0,5$ a 0,9$)$, devido provavelmente ao efeito indireto de correlação positiva de altura com acamamento e desta com produtividade. A correlação obtida com número de dias para maturidade, foi em média maior que 0,4 .

De acordo com os resultados obtidos nos trabalhos de correlação efetuados, pode-se considerar que ocorreu uma grande variação na magnitude dos valores encontrados, às vezes envolvendo troca de sinais. Tal fato, revela a diferença que pode existir entre uma população e outra de soja, e ao mesmo tempo, confirma a necessidade de se obter estimativas de correlação para cada população em particular, sobretudo se 0 intuito for eficiência no processo seletivo. O trabalho de Weiss (1949) foi um dos pioneiros a evidenciar a grande variação existente nas estimativas de correlação para vários caracteres em soja. 


\section{MATERIAL E MÉTODOS}

\subsection{Material genético}

O material genético utilizado compreendeu 60 populações originadas através de cruzamentos óctuplos de soja, pertencentes ao primeiro ciclo de um programa de seleção recorrente conduzido no Setor de Genética Aplicada às Espécies Autógamas do Departamento de Genética da ESALQ/USP. A escolha dos parentais utilizados nos cruzamentos óctuplos ocorreu com base nos resultados obtidos de três experimentos instalados nos locais Anhembi, ESALQ e Sertãozinho (Vello, 1992a; Soldini, 1993), entre os anos de 1983/84 e 1984/85. Destes experimentos, foram selecionados 40 parentais que foram combinados na forma de cruzamentos óctuplos, cuja escolha foi baseada em critérios de divergência genética, na capacidade de combinação, e nos altos níveis de produtividade, sendo cada conjunto de dez parentais pertencentes a um de quatro ciclos de maturação: precoce, semi-precoce, semi-tardio e tardio (Apêndice 1).

Entende-se por cruzamentos óctuplos, o processo sucessivo de três gerações de recombinações, das quais, a primeira realizou-se em 1989 e envolveu quatro dialelos completos $10 \times 10$, com 45 cruzamentos biparentais para cada grupo de maturação, totalizando 180 cruzamentos simples. A segunda geração, realizada em 1990, foi composta por 45 cruzamentos quádruplos $\left(F_{1[4]}\right)$ envolvendo os híbridos $F_{1}$ dos ciclos precoce com semi-precoce e 45 cruzamentos quádruplos entre os híbridos $F_{1}$ semitardios com tardios. A terceira geração de recombinação, ocorrida em 1991, originou 60 cruzamentos óctuplos $\left(F_{1[8]}\right)$, sendo que cada cruzamento foi composto por dois parentais de cada grupo (precoce, semi-precoce, semi-tardio e tardio), conforme 
apresentado nos Apêndices 1 e 2 e na Figura 1. Os cruzamentos realizados entre os híbridos quádruplos para obtenção dos híbridos óctuplos foram feitos em casa-devegetação tropical (telado) nos meses de outubro de 1991 a maio de 1992, pois nas condições ambientais de Piracicaba $\left(23^{\circ}\right.$ de latitude e $534 \mathrm{~m}$ de altitude), os telados permitem a realização de cruzamentos diários, no período de 10 às 16 horas, durante os meses de setembro a abril, sempre que a umidade relativa do ar não for excessiva (Vello, 1992a,b).

Todas as gerações de endogamia foram conduzidas pela equipe do Setor de Genética Aplicada às Espécies Autógamas do Departamento de Genética da ESALQ/USP, sendo a geração $\mathrm{F}_{1[8]}$ coordenada pelo Eng ${ }^{\circ}$. Agr ${ }^{\circ}$. Lafayete Silva em 1993; a geração $F_{2[8]}$ foi coordenada pela $\mathrm{Eng}^{\mathrm{a}}$. Agr $^{\mathrm{a}}$. Ângela Lopes em 1994. Este trabalho envolve as gerações $F_{4}, F_{5}$ e $F_{6}$. Na geração $F_{3}$, foi praticada seleção de plantas individuais e, então, foi aberta uma progênie para cada indivíduo selecionado; a seguinte simbologia foi adotada para representar as gerações trabalhadas: $F_{4: 3[8]}, F_{5: 3[8]}$ e $F_{6: 3[8]}$.

Nestas três gerações, as linhagens foram classificadas em diferentes ciclos de maturação. Na geração $\mathrm{F}_{4: 3[8]}$, a classificação foi feita nos grupos, precoce, intermediário e semi-tardio. A grande segregação para ciclo (número de dias para maturidade), fez com que as linhagens fossem novamente reagrupadas por ciclo; assim, nas gerações $F_{5: 3}$ e $\mathrm{F}_{6: 3}$, as linhagens foram classificadas em quatro grupos de maturação (precoce, semiprecoce, intermediário e semi-tardio).

Dessa forma, considerou-se algumas siglas para representação dos grupos ou ciclos de maturação (CM): progênies (linhagens experimentais) precoces (PPR), progênies semi-precoces (PSP), progênies intermediárias (PIN) e progênies semi-tardias (PST). Para o agrupamento das progênies na geração $F_{4: 3[8]}$, utilizou-se três intervalos de maturação: 112-125 dias (PPR), 126-137 dias (PIN) e 138-148 dias (PST). Já para as gerações $F_{5: 3[8]}$ e $F_{6: 3[8]}$, os intervalos foram: 112-119 dias (PPR), 120-127 dias (PSP), 128-135 dias (PIN) e 136-145 dias (PST). 


\subsection{Caracterização dos ambientes experimentais}

Os experimentos foram instalados nos anos agrícolas 1995/96 (Geração $F_{4: 3[8]}$ ), 1996/97 (Geração $F_{5: 3[8]}$ ) e 1997/98 (Geração $F_{6: 3[8]}$ ). Os locais de condução dos experimentos foram ESALQ, Anhembi e Areão, situados dentro do município de Piracicaba. Todas as áreas experimentais pertencem ao Departamento de Genética da ESALQ/USP. O local ESALQ possui solo tipo terra roxa estruturada, textura argilosa, relevo ondulado e situa-se dentro da sede da ESALQ/USP. O local Anhembi, caracteriza-se por possuir solo aluvial distrófico, textura médio-arenosa, relevo plano, situando-se na Estação Experimental Anhembi e distando cerca de $60 \mathrm{~km}$ da sede da ESALQ/USP; a acidez do solo foi neutralizada pela aplicação de calcário dolomítico nos dois anos anteriores aos experimentos. O local Areão possui solo tipo podzólico vermelho-amarelo distrófico, textura médio-argilosa, relevo do tipo ondulado, e situa-se na Fazenda Areão, distante cerca de $5 \mathrm{~km}$ da sede da ESALQ/USP. O solo dos três locais foi uniformizado com cultivo e incorporação de aveia preta (Avena strigosa Sckeb) no inverno anterior.

O município de Piracicaba situa-se a $22^{\circ} 42^{\prime} 30^{\prime \prime}$ de latitude Sul e $47^{\circ} 39^{\prime} 00^{\prime \prime}$ de longitude Oeste, estando a uma altitude média de $540 \mathrm{~m}$ acima do nível do mar. As informações referentes às temperaturas, umidades relativas médias, pluviosidades e fotoperiodo, ocorridos durante a fase de execução dos experimentos encontram-se no Apêndice 3. Tais dados foram fornecidos pelo Setor de Física e Meteorologia do Departamento de Ciências Exatas da ESALQ/USP. Os critérios utilizados para interpretação das análises de solo para o Estado de São Paulo estão de acordo com Malavolta et al. (1989), bem como as análises de solo relativas às coletas realizadas nas áreas experimentais, são apresentadas nos Apêndices 4 e 5.

O preparo do solo realizado foi similar para todos os experimentos instalados, sendo feitas uma aração e duas gradagens. O adubo mineral utilizado foi 4-20-20 (N$\mathrm{P}_{2} \mathrm{O}_{5}-\mathrm{K}_{2} \mathrm{O}$ ), sendo aplicados $25 \mathrm{~g}$ da fórmula por metro de sulco, perfazendo um total de $500 \mathrm{~kg} / \mathrm{ha}$. Na semeadura, as sementes foram distribuidas nos sulcos e promoveu-se a inoculação das sementes com inoculante comercial contendo cepas de Bradyrhizobium 
japonicum diluído em água a uma concentração de $800 \mathrm{~g} / 201$, através de pulverização costal. O fornecimento de água foi feito logo após a semeadura e algumas vezes nas fases de maior necessidade da cultura (fase de florescimento e granação das vagens). $\mathrm{O}$ controle fitossanitário foi realizado principalmente para o controle de percevejos, aplicando inseticida (Endosulfon a 1,251/ha). Para o controle de plantas invasoras, foi aplicado herbicida pré-emergente (Trifluralin a 1,81/ha) incorporado antes da semeadura, complementando-se com capinas manuais quando necessário.

\subsection{Instalação dos experimentos}

\subsubsection{Geração $F_{4: 3[8]}$}

Conforme mencionado, foram abertas progênies na geração $F_{3}$, após a colheita de sementes de plantas individuais. Devido ao número limitado de sementes por progênie, a geração $\mathrm{F}_{4: 3[8]}$ foi conduzida somente em um local (campo experimental da ESALQ/USP), no delineamento de blocos aumentados de Federer, sem repetição, com semeaduras em 21-22/11/1995.

Cada parcela foi composta por duas fileiras de 5 metros de comprimento e espaçadas de 0,5 metros entre si. $O$ espaço entre parcelas foi de 1,0 metro. A área total compreendeu $7,5 \mathrm{~m}^{2}(0,75 \mathrm{~m} \times 5 \mathrm{~m} \times 2$ fileiras $)$ e área útil experimental para a tomada dos dados compreendeu somente os 4,0 metros centrais da parcela das duas fileiras centrais da parcela, sendo eliminados 0,5 metros de cada extremidade. $\mathrm{O}$ espaçamento de 1,0 m entre parcelas tem por objetivo eliminar ou minimizar as possíveis diferenças de competição entre genótipos diferentes. O maior espaçamento entre parcelas também facilitou as avaliações no campo e acolheita. As plantas das progênies $F_{4: 3[8]}$ devem ter sido beneficiadas pelo espaçamento maior $(1,0 \mathrm{~m})$ entre parcelas. A área útil da cada parcela correspondeu a $6 \mathrm{~m}^{2}(0,75 \mathrm{~m} \times 4 \mathrm{~m} \times 2$ fileiras $)$.

$O$ experimento foi composto por um total de 715 progênies $F_{4: 3[8]}$ divididas em três grupos de maturação: 229 precoces, 350 intermediárias e 136 tardias. As progênies precoces foram dispostas em dez conjuntos, as progênies intermediárias em 14 conjuntos 
e as tardias em seis conjuntos; em todos os grupos de maturação um conjunto foi formado em média por 25 progênies e quatro testemunhas. Devido ao fato de ter ocorrido divisão por grupo de maturação, foram utilizadas testemunhas diferentes para 0 ciclo precoce (BR-16, IAC-Foscarin-31, Primavera e IAS-5), para o ciclo intermediário (Bossier, Stwart, IAC-12 e IAC-100) e para o ciclo tardio (IAC-8, IAC-11, IAC-4 e Santa Rosa). A disposição das testemunhas dentro dos conjuntos foi uniforme, ficando cada testemunha distribuída ou intercalada a cada $1 / 4$ do total de parcelas do conjunto; este critério foi adotado para todos os ciclos de maturação e todas as gerações avaliadas. Após a condução desta geração, foi efetuada uma seleção em torno de $50 \%$ das melhores progênies. Esta seleção foi efetuada de acordo com o melhor desempenho obtido das progênies, para os caracteres avaliados, que serão citados adiante.

\subsubsection{Geração $F_{5: 3[8]}$}

Devido ao fato da geração $F_{4: 3[8]}$ ter sido colhida em parcelas de $6 \mathrm{~m}^{2}$, e não em plantas individuais, o número de sementes por linhagens para esta geração teve uma aumento significativo em relação à geração anterior, permitindo que a geração $F_{5: 3[8]}$ fosse conduzida em dois locais (campo experimental da ESALQ/USP e Estação Experimental Anhembi). O delineamento utilizado foi o de blocos ao acaso com repetições estratificadas em conjuntos experimentais, sendo utilizadas duas repetições por local. As semeaduras ocorreram em 12/11/1996 (ESALQ) e 19/11/1996 (Anhembi).

Cada parcela foi composta por quatro fileiras de 5 metros de comprimento e espaçadas de 0,5 metros, totalizando $10 \mathrm{~m}^{2}$; a área útil para a tomada dos dados foi composta pelas duas fileiras centrais da parcela, eliminando-se 0,5 metros de cada extremidade, restando então para a colheita, uma área útil de $4 \mathrm{~m}^{2}$.

Após a seleção realizada em $\mathrm{F}_{4: 3[8]}$, permaneceram 310 progênies para a geração $\mathrm{F}_{5: 3[8]}$. Conforme mencionado, a segregação remanescente para número de dias para maturidade (ciclo), tornou necessário reagrupar as progênies em ciclos de maturação (precoce, semi-precoce, intermediário e semi-tardio). Dessa maneira, das 310 progênies, 17 eram do ciclo precoce, 60 eram do ciclo semi-precoce, 179 do ciclo intermediário e 
54 progênies do ciclo semi-tardio. As 17 progênies do ciclo precoce juntamente com as quatro testemunhas formaram um único conjunto. As progênies semi-precoces e intermediárias em três e nove conjuntos, respectivamente; nos dois últimos experimentos, cada conjunto compreendeu em média 20 progênies e quatro testemunhas. Finalmente, as progênies do ciclo semi-tardio foram subdivididas em três conjuntos, cada um contendo em média 18 progênies e quatro testemunhas. A incidência de cancroda-haste, principalmente o ciclo tardio, levou à substituição de algumas testemunhas suscetíveis a tal doença, em todos os ciclos de maturação. Dessa forma, as novas testemunhas utilizadas foram: ciclo precoce (Primavera, IAS-5, IAC-20 e FT-Cometa), ciclo semi-precoce (FT-Cometa, BR-16, IAC-18 e IAC-Foscarin-31), ciclo intermediário (IAC-19, IAC-100, IAC-12 e Bossier) e ciclo semi-tardio (IAC-11, IAC-4, IAC-8 e Stwart). Como na geração anterior, a seleção foi realizada de acordo com a melhor performance das progênies para os caracteres avaliados (citados adiante), realizando-se uma nova seleção de aproximadamente $50 \%$.

\subsubsection{Geração $F_{6: 3[8]}$}

A geração $F_{6: 3[8]}$, a exemplo da geração $F_{5: 3[8]}$, foi conduzida em três locais diferentes (campo experimental da ESALQ/USP, Estação Experimental Anhembi e Fazenda Areão). O delineamento utilizado foi o de blocos ao acaso com repetições estratificadas em conjuntos experimentais, sendo utilizadas duas repetições por local. Semelhantemente à geração anterior, a parcela experimental foi composta por quatro fileiras de 5 metros de comprimento e espaçadas de 0,5 metros $\left(10 \mathrm{~m}^{2}\right)$; para a tomada dos dados foram utilizadas as duas fileiras centrais, eliminando-se 0,5 metros de cada extremidade, totalizando uma área útil de $4 \mathrm{~m}^{2}$. As semeaduras foram feitas em 12/11/1997 (ESALQ), 25/11/97 (Anhembi) e 05/11/1997 (Areão).

Após a seleção efetuada na geração anterior, permaneceram 127 progênies $F_{6: 3[8]}$ que foram agrupadas dentro dos ciclos de maturação, sendo 17 precoces, 30 semiprecoces, 60 intermediárias e 20 semi-tardias, seguindo a mesma classificação da geração anterior. Somente as progênies precoces não sofreram seleção na geração 
anterior, sendo agrupadas em um único conjunto com quatro testemunhas; as semiprecoces foram agrupadas em dois conjuntos de 15 progênies e quatro testemunhas; as progênies do ciclo intermediário foram agrupadas em três conjuntos de 20 progênies e quatro testemunhas; as 20 progênies semi-tardias, juntamente com quatro testemunhas, formaram um único conjunto experimental. As testemunhas para cada ciclo de maturação, foram as mesmas utilizadas na geração $F_{5: 3[8]}$.

\subsection{Caracteres avaliados}

Em todas as gerações conduzidas, foram avaliados os seguintes caracteres agronômicos:

- Número de dias para a maturidade (NDM): caráter avaliado no estádio $R_{8}$ (Fehr \& Caviness, 1977) de desenvolvimento da planta, compreendendo o periodo de dias entre a data de semeadura e a data onde pelo menos $50 \%$ das plantas da área útil possuiam $95 \%$ ou mais, das vagens maduras, sendo expresso em dias;

- Altura da planta na maturidade (APM): caráter avaliado no estádio $R_{8}$ de desenvolvimento da planta, compreendendo a distância da haste principal entre o colo e a inserção da vagem mais distal, obtida como um valor médio das medidas de duas plantas representativas de cada uma das duas fileiras da área útil da parcela, sendo expressa em $\mathrm{cm}$;

- Valor agronômico (VA): caráter avaliado no estádio $\mathrm{R}_{8}$ de desenvolvimento da planta, através de uma escala de notas visuais, a qual varia de 1 (plantas com características agronômicas ruins) a 5 (plantas com ótimas caracteristicas agronômicas), sendo a nota atribuida representativa de um conjunto de caracteres visuais adaptativos: arquitetura da planta, quantidade de vagens cheias, vigor e sanidade da planta, debulha prematura das vagens, acamamento e retenção foliar na maturidade; 
- Acamamento (Ac): caráter avaliado no estádio $R_{8}$ de desenvolvimento da planta através de uma escala de notas visuais, variando de 1 (todas as plantas eretas) a 5 (todas as plantas acamadas);

- Produtividade de grãos (PG): caráter obtido através do peso dos grãos da área útil da parcela, após a colheita, beneficiamento das plantas e posterior secagem dos grãos (até a umidade de $13 \%$ ). Os dados obtidos em gramas por parcela foram transformados para quilogramas por hectare $(\mathrm{Kg} / \mathrm{ha})$;

- Reação ao cancro da haste da soja (CHS): caráter avaliado visualmente em condições de campo, com infestação natural, através do nivel de dano e de sintomas das plantas da parcela, usando-se quatro classificações: alta reação (AR), média reação (MR), baixa reação (BR) e nenhuma reação (NR) ao CHS. As notas atribuidas a esta classificação foram respectivamente $4,3,2 \mathrm{e} 1$.

Para os caracteres Ac e VA foram atribuídas notas intermediárias entre os valores inteiros de nota, ou seja, a escala incluiu as notas de 1,$5 ; 2,5 ; 3,5$ e 4,5. Antes de se efetuarem as análises estatísticas, os dados referentes a estes dois caracteres e CHS foram transformados para $\sqrt{x+0,5}$, de modo a se obter uma maior aproximação dos dados à curva de distribuição normal.

\subsection{Análises estatístico-genéticas}

As análises dos dados foram realizadas utilizando-se o procedimento GLM do programa SAS para computadores (SAS INSTITUTE INC., 1996), além do programa GENES (Cruz, 1997) e do programa EXCEL para Windows 98. 


\subsubsection{Análise de resíduos}

Em uma fase anterior à análise de variância dos dados experimentais, realizou-se uma análise de resíduos para todos os caracteres avaliados, para cada ciclo de maturação. O principal objetivo desta análise foi verificar e detectar a existência de dados discrepantes ("outliers"). Além desta função, a análise de resíduos também auxilia na verificação da homogeneidade das variâncias, no ajustamento dos erros à distribuição normal, além das suposições de independência dos erros e de aditividade no modelo matemático.

Auxiliando a verificação da presença dos "outliers", utilizou-se gráficos envolvendo os resíduos padronizados e o valor ajustado, chamado pelo modelo de valor predito, para cada observação. Através dos gráficos, se for constatada a presença de "outliers", estes dados serão substituídos pelos valores preditos correspondentes e, então, nova análise de resíduos é realizada, para confirmar a resolução do problema. Tal procedimento é efetuado para todos os caracteres e em todos os ciclos de maturação. Resultados satisfatórios com a utilização da análise gráfica de resíduos para substituição de "outliers" foram obtidos por Carbonell (1995) e Rocha (1998).

De acordo com Parente (1984), o resíduo padronizado $\left(\mathrm{d}_{\mathrm{ij}}\right)$ é calculado pela seguinte equação:

$$
\mathrm{d}_{\mathrm{ij}}=\frac{\mathrm{e}_{\mathrm{ij}}}{\sqrt{\mathrm{QMRes}}}
$$

onde:

$\mathrm{e}_{\mathrm{ij}}$ : resíduo resultante do ajuste do modelo escolhido, sendo:

$$
\begin{aligned}
& e_{i j}=\left[Y_{i j} \text { (observado) }-Y_{i j} \text { (ajustado) }\right], \text { com } \\
& Y_{i j} \text { (ajustado) }=\hat{m}+\hat{t}_{i}+\hat{b}_{j}
\end{aligned}
$$

QMRes : quadrado médio do resíduo obtido na análise de variância individual. 


\subsubsection{Análises de variâncias}

Foram realizadas análises de variâncias individuais, análises por ano e análises conjuntas para as progênies e testemunhas dos experimentos. Para as análises individuais, foram considerados apenas os dados de cada experimento individualmente; para a análise por ano foram tomados os dados dos experimentos realizados dentro de um determinado ano agrícola; para a análise conjunta foram tomados os dados experimentais de todos os experimentos nos vários locais e anos agrícolas.

Para os procedimentos das análises, foram considerados fixos os efeitos de tratamentos (progênies e testemunhas), visto que os mesmos originam-se de diferentes cruzamentos, não representando uma mesma população, ou uma mesma genealogia. $O$ efeito de locais também foi considerado fixo, visto que os mesmos diferem entre si quanto à uma série de características como: tipo de solo, fertilidade e topografia, e não representam toda a região de Piracicaba. Os demais efeitos como conjuntos experimentais e repetições foram considerados aleatórios.

\subsubsection{Análise de variância para testemunhas}

Conforme mencionado, o delineamento utilizado para o ano 1995/96 foi o de blocos aumentados de Federer e para os anos agrícolas 1996/97 e 1997/98 utilizou-se blocos ao acaso com repetições estratificadas em conjuntos experimentais. Para os dois últimos anos, a significância dos conjuntos experimentais e da interação destes com as outras fontes de variação dentro dos modelos, significaria a necessidade de serem feitos ajustes das médias das progênies em função das médias das testemunhas, de modo a permitir as análises em blocos ao acaso. A não-significância indicaria que as análises poderiam ser feitas prontamente em blocos ao acaso, sem a necessidade de ajustes. Para se verificar estas significâncias relativas aos conjuntos, foram realizadas as análises de variância somente com os dados das testemunhas.

Realizou-se análises de variância individuais, seguidas de análises por ano e, finalmente, análise conjunta entre os anos para as testemunhas, sendo que os esquemas 
de análise de variância utilizados encontram-se nos Apêndices 6,7 e 8, respectivamente. Vale lembrar que estas análises foram aplicadas para todos os caracteres e ciclos de maturação.

Alguns trabalhos realizados com soja utilizaram as análises de variância individuais e conjuntas para testemunhas, com o mesmo objetivo citado (Farias Neto, 1987; Soldini, 1993; Hiromoto, 1996; Azevedo Filho, 1997; Rocha, 1998) obtendo-se resultados satisfatórios.

$\mathrm{O}$ modelo matemático utilizado para a análise de variância individual das testemunhas foi o seguinte:

$$
Y_{i k}=\mu+t_{i}+c_{k}+e_{i k}
$$

onde:

$Y_{i k}$ : observação referente à testemunha " $i$ " no conjunto " $k$ ";

$\mu$ : média geral do caráter;

$t_{i}$ : efeito fixo da testemunha " $i$ "; sendo $i=1, \ldots, T$;

$c_{k}$ : efeito aleatório do conjunto " $k$ "; sendo $k=1, \ldots, C$;

$e_{i k}$ : erro associado à parcela "ik", admitido ser independente e com distribuição normal de média zero e variância $\sigma^{2}$.

O modelo matemático para a análise de variância conjunta de testemunhas por ano foi :

$$
Y_{i k l}=\mu+t_{i}+l_{l}+1 t_{l i}+c / l_{k(l)}+c t_{k i}+e_{i k l}
$$

onde:

$Y_{\mathrm{ikl}}=$ observação referente à testemunha "i", no conjunto " $k$ ", no local "l";

$\mu=\quad$ média geral do caráter;

$t_{i}=\quad$ efeito fixo da testemunha " $i$ ', sendo $i=1, \ldots, T$;

$l_{l}=$ efeito fixo do local "l", sendo $l=1, \ldots, L$;

$\mathrm{lt}_{\mathrm{l}}=$ = efeito fixo da interação entre a testemunha "i" e o local "l";

$\mathrm{c} / \mathrm{l}_{\mathrm{k}(\mathrm{l})}=$ efeito aleatório do conjunto " $\mathrm{k}$ " dentro do local "l", $\mathrm{k}=1, \ldots, \mathrm{C}$; 
$\mathrm{ct}_{\mathrm{ki}}=$ efeito aleatório da interação entre o conjunto " $\mathrm{k}$ " e a testemunha "ci";

$\mathrm{e}_{\mathrm{ikl}}=$ efeito aleatório do erro experimental médio associado à parcela "ikl", admitido ser independente e com distribuição normal de média zero e variância $\sigma^{2}$.

Para a análise de variância conjunta entre anos para as testemunhas, utilizou-se o seguinte modelo matemático:

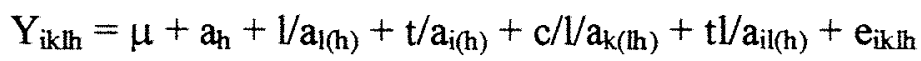

onde:

$Y_{i k l h}=$ observação referente à testemunha "i", no conjunto " $k$ ", no local "l", no ano "h";

$\mu=\quad$ média geral do caráter;

$a_{h}=\quad$ efeito fixo do ano " $h$ "; sendo $h=1, \ldots, A$;

$1 / a_{1(h)}=$ efeito fixo do local "l", dentro do ano " $h$ "; sendo $l=1, \ldots, L$;

$t / a_{i}(h)=$ efeito fixo da testemunha "i", dentro do ano " $h$ "; sendo $i=1, \ldots, T$;

$\mathrm{c} / \mathrm{l} / \mathrm{a}_{\mathrm{k}(\mathrm{h})}=$ efeito aleatório do conjunto " $\mathrm{k}$ ", dentro do local "l", dentro do ano " $\mathrm{h}$ ", sendo $\mathrm{k}=1, \ldots, \mathrm{C}$;

$\mathrm{t} / \mathrm{a} \mathrm{i}(\mathrm{h})=$ efeito aleatório da interação entre a testemunha " $\mathrm{i}$ " e o local "l", dentro do ano "h"; sendo $\mathrm{i}=1, \ldots, \mathrm{T}$;

$\mathrm{e}_{\mathrm{iklh}}=$ erro experimental associado à parcela "iklh", considerando-se sua independência, com distribuição normal de média zero e variância $\sigma^{2}$.

\subsubsection{Análise de variância para tratamentos}

Depois de realizadas as análises de variância para testemunhas, e desde que constatada não-significância para fontes de variação envolvendo conjuntos e interações conjuntos $\mathrm{x}$ testemunhas, pôde-se proceder às análises de variância para as progênies experimentais, ignorando-se então os efeitos de conjuntos experimentais. 
A exemplo do grupo das testemunhas, também para o grupo das progênies, realizou-se análises de variância individuais, seguidas de análises por ano e finalmente a análise conjunta entre os anos, para todos os caracteres e ciclos de maturação. Para o primeiro ano (1995/96), a análise individual e por ano seria a mesma, devido à existência de somente um local com experimento instalado.

$\mathrm{Na}$ análise de blocos aumentados, considerou-se o efeito de conjuntos experimentais como repetições. Assim, os efeitos de repetições e tratamentos foram utilizados como fontes de variação. $O$ esquema de análise de variância empregado pode ser consultado no Apêndice 9.

O modelo matemático utilizado para a análise de variância individual de blocos aumentados foi o seguinte:

$$
Y_{f j}=\mu+g_{f}+r_{j}+e_{f j}
$$

onde:

$Y_{\mathfrak{f j}}=$ observação do tratamento " $\mathrm{f}$ ", na repetição “ $\mathrm{j}$ ”

$\mu=$ média geral do caráter;

$\mathrm{g}_{\mathrm{f}}=$ efeito fixo do tratamento " $\mathrm{f}$ ", sendo $\mathrm{f}=1, \ldots, \mathrm{G}$;

$r_{j}=$ efeito aleatório da repetição "j", sendo $j=1, \ldots, R$;

$\mathrm{e}_{\mathrm{fj}}=$ erro experimental associado à parcela "fj", admitido ser independente e com distribuição normal de média zero e variância $\sigma^{2}$.

Para os anos agrícolas de 1996/97 e 1997/98, nas análises individuais de blocos ao acaso, considerou-se os efeitos de repetições e progênies como fontes de variação, conforme pode ser observado no esquema de análise de variância do Apêndice 10.

$\mathrm{O}$ modelo matemático utilizado para a análise de variância individual de tratamentos foi:

$$
Y_{s j}=\mu+p_{s}+r_{j}+e_{s j}
$$

onde:

$Y_{s j}=$ observação da progênie "s", na repetição “j”; 
$\mu=$ média geral do caráter;

$p_{s}=$ efeito fixo da progênie " $s$ "; sendo $s=1, \ldots, P$;

$r_{j}=$ efeito aleatório da repetição " $j$ ”; sendo $j=1, \ldots, R$;

$\mathrm{e}_{\mathrm{sj}}=$ erro experimental associado à parcela "sj", considerando-se sua independência e distribuição normal com média zero e variância $\sigma^{2}$.

Para a análise de variância de blocos ao acaso para tratamentos por ano, o esquema utilizado encontra-se no Apêndice 11. Para esta análise foi adotado o seguinte modelo matemático:

$$
\mathrm{Y}_{\mathrm{lif}}=\mu+\mathrm{l}_{\mathrm{l}}+\mathrm{r} / \mathrm{l}_{\mathrm{j}(\mathrm{l})}+\mathrm{g}_{\mathrm{f}}+\mathrm{gl}_{\mathrm{fl}}+\mathrm{e}_{\mathrm{jff}}
$$

onde:

$Y_{\mathrm{ljf}}=$ observação referente ao tratamento "f", na repetição " $\mathrm{j}$ ", no local "l";

$\mu=\quad$ média geral do caráter;

$l_{1}=\quad$ efeito fixo do local "l"; sendo $l=1, \ldots, L$;

$\mathrm{r} / \mathrm{l}_{\mathrm{j}(1)}=$ efeito aleatório da repetição " $\mathrm{j}$ " dentro do local "l”; sendo $\mathrm{j}=1, \ldots, \mathrm{R}$;

$\mathrm{g}_{\mathrm{f}}=$ efeito fixo do tratamento " $\mathrm{f}$ ", sendo $f=1, \ldots, \mathrm{G}$;

$\mathrm{gl}_{\mathrm{fl}}=$ efeito fixo da interação entre o tratamento "f" e o local "l";

$\mathrm{e}_{\mathrm{ljf}}=$ erro experimental médio associado à parcela "ljf", admitido ser independente e com distribuição normal de média zero e variância $\sigma^{2}$.

Para a análise conjunta total, ou seja, envolvendo todos os experimentos instalados em todos os anos agrícolas, foram agrupados somente os tratamentos que eram comuns para os seis experimentos, já que de um ano para o outro ocorreram seleções, reduzindo o número de tratamentos a ser avaliado. Dessa forma, a fonte de variação "ambientes" foi desdobrada para estudo dos efeitos de anos, locais dentro do ano 1996 e dentro de 1997, efeito do local ESALQ nos três anos avaliados e efeito do local Anhembi nos dois anos.

Antes porém, de se efetuar o agrupamento dos experimentos, realizou-se o teste de homogeneidade de variâncias para os experimentos instalados. Este teste consiste em 
dividir o maior quadrado médio do resíduo obtido na análise individual, por aquele de menor valor, sendo que este quociente não poderá exceder ao valor 7,0 (Pimentel Gomes, 1990). Este teste foi feito para todos os caracteres avaliados e para todos os ciclos de maturação. Logo após, realizou-se a análise conjunta para os seis ambientes, para cada ciclo de maturação, tendo como principal objetivo a detecção de possiveis interações significativas de genótipos $\mathrm{x}$ ambientes, sendo os genótipos representados por tratamentos, como pode ser observado no esquema de análise de variância do Apêndice 12. Esta interação genótipos $\mathrm{x}$ ambientes ainda incluiu dois esquemas de desdobramentos, sendo que o primeiro testou os efeitos de progênies ou testemunhas $\mathrm{x}$ locais, dentro do ano 1996 e 1997. O segundo testou o efeito de progênies ou testemunhas $\mathrm{x}$ anos dentro do local ESALQ e Anhembi. O modelo matemático utilizado foi o seguinte:

$$
Y_{f j w}=\mu+z_{w}+r / z_{j(w)}+g_{f}+g z_{f w}+e_{f j w}
$$

onde:

$$
\begin{aligned}
& Y_{\mathrm{fjw}}=\text { observação do tratamento "f", na repetição “j”, no ambiente "w"; } \\
& \mu=\quad \text { média geral do caráter; } \\
& z_{w}=\quad \text { efeito fixo do ambiente " } w \text { ", sendo } w=1, \ldots, Z \text {; } \\
& r / z_{j(w)}=\text { efeito aleatório da repetição “j”, dentro do ambiente "w"; sendo } j=1, \ldots, R \text {; } \\
& \mathrm{gf}=\quad \text { efeito fixo do tratamento "f", } \mathrm{f}=1, \ldots, \mathrm{G} \text {; } \\
& g z_{\mathrm{fw}}=\text { efeito fixo da interação entre o tratamento "f" e o ambiente " } w \text { "; } \\
& \mathrm{e}_{\mathrm{f} j \mathrm{w}}=\text { erro experimental médio associado à parcela "fjw", admitido ser }
\end{aligned}
$$

\subsubsection{Estabilidade fenotípica}

As metodologias para estudo da adaptabilidade e estabilidade fundamentam-se na interação genótipo x ambiente. Uma vez detectada a significância desta interação, podese proceder às análises, sendo que todas as metodologias existentes destinam-se à avaliação de um grupo de genótipos em diversos ambientes. 
No presente trabalho, utilizou-se a metodologia de Wricke (1965) para estimar os parâmetros de adaptabilidade e estabilidade das progênies e testemunhas, para cada ciclo de maturação, bem como para cada caráter avaliado.

De acordo com Oliveira (1976), esta metodologia não utiliza a análise de regressão linear. Desta forma, o parâmetro de estabilidade estimado é denominado de "ecovalência", o qual é obtido pela partição da soma de quadrados da interação genótipo $\mathrm{x}$ ambiente, sendo que cada partição referida corresponde ao valor de um determinado tratamento, ou seja, o quanto este tratamento específico contribui para a soma de quadrados da interação genótipo $\mathrm{x}$ ambiente. Pode-se considerar, portanto, que o objetivo do teste é distribuir o efeito total da interação genótipo $x$ ambiente obtido na análise de variância conjunta, determinando-se com isso quais os tratamentos que influem mais ou menos para a interação. A metodologia de Plaisted \& Peterson (1959) possui objetivo similar à de Wricke, porém o objetivo da primeira é decompor a variância da interação genótipo $\mathrm{x}$ ambiente, enquanto que o da segunda é decompor a soma de quadrados.

A partição da soma de quadrados da metodologia de Wricke, é estimada por:

$$
\omega_{i}=\sum_{j}(\hat{G} A)_{i j}^{2}
$$

onde:

$\omega_{\mathrm{i}}$ ou $\mathrm{eco}_{\mathrm{i}}=$ ecovalência estimada, ou contribuição do genótipo "i" para a $\mathrm{SQ}_{\mathrm{GxE}}$ total

$$
\hat{G}_{i j}=\bar{Y}_{i j}-\bar{Y}_{i .}-\bar{Y}_{i j}+\bar{Y}_{. .}
$$

onde:

$$
\begin{aligned}
& \bar{Y}_{\mathrm{ij}}=\text { média do genótipo "i" no ambiente "j"; } \\
& \bar{Y}_{\mathrm{i} .}=\text { média do genótipo "i"; } \\
& \overline{\mathrm{Y}}_{\mathrm{j}}=\text { média do ambiente "j"; } \\
& \overline{\mathrm{Y}}_{\mathrm{Y}}=\text { média geral; }
\end{aligned}
$$


Os genótipos mais estáveis serão aqueles associados às menores estimativas de $\omega_{i}$ ou eco ("ecovalência"), e os menos estáveis, consequentemente, possuirão maiores valores de $\mathrm{eco}_{\mathrm{i}}$.

Pode-se testar a significância dos valores de $\mathrm{eco}_{i}$ obtidos, utilizando-se a seguinte equação:

$$
F_{(z, e)}=\frac{Q M_{\text {ecoi }}}{Q M_{\text {Res }}}
$$

onde:

$\mathrm{z}$ : $\quad$ graus de liberdade de experimentos ou ambientes onde os genótipos foram testados;

e : $\quad$ graus de liberdade do erro ou resíduo da análise conjunta;

$\mathrm{QM}_{\text {ecoi }}$ : quadrado médio da ecovalência, obtido por:

$$
\mathrm{QM}_{\mathrm{ecoi}}=\frac{\mathrm{ecOi}}{\mathrm{z}}
$$

$\mathrm{QM}_{\text {Res }}$ : quadrado médio do erro da análise conjunta;

Pela fórmula acima, observa-se que o QM da ecovalência atribuída ao genótipo i $\left(\mathrm{QM}_{\mathrm{ecoi}}\right)$ é obtido a partir da divisão do valor da ecovalência do genótipo pelo número de graus de liberdade de ambientes onde os genótipos foram testados.

Um outro cálculo importante realizado é a ecovalência em porcentagem ou eco\%. Através deste cálculo, poderemos saber qual a porcentagem de contribuição de cada genótipo, ou seja, se a interação na sua totalidade representa $100 \%$, qual será a contribuição em porcentagem de um determinado genótipo "i" para este total. Somandose as contribuições relativas de todos os genótipos que participam da análise dentro do ciclo de maturação, perfazer-se-á um total de 100\% obrigatoriamente. Este cálculo foi realizado para todos os ciclos de maturação e caracteres avaliados.

$\mathrm{O}$ cálculo é realizado pela seguinte fórmula: 


$$
\text { econ } \%=\frac{\text { ecoi }}{\sum e_{\text {ecoin }}}
$$

onde :

$\mathrm{eco}_{\mathrm{n}} \%$ : ecovalência em porcentagem do genótipo "i" para o caráter "n";

$\mathrm{eco}_{\mathrm{i}}$ : ecovalência do genótipo "i";

$\sum \mathrm{eco}_{\text {in }}$ : somatório das ecovalências dos "i" genótipos avaliados para o caráter "n".

A partir dos dados de eco\%, calculou-se as médias destes valores para cada genótipo, pela seguinte equação:

$\mathrm{Meco} \%=\frac{\sum \mathrm{eco}_{\mathrm{n}} \%}{\mathrm{~m}}$

onde :

Meco \%: média entre as eco\% dos caracteres avaliados (NDM, APM, Ac, VA, CHS e PG) para o genótipo "i";

$\sum \mathrm{eco}_{\mathrm{n}} \%$ : somatório das eco $\%$ de todos os " $\mathrm{n}$ " caracteres avaliados para o genótipo "i";

$\mathrm{m}$ : número total de caracteres avaliados;

Estimou-se também, a variància da ecovalência em porcentagem (Veco\%), e logo em seguida, pela extração da sua raiz quadrada, obteve-se os valores dos desvios padrões de eco\% $(\mathrm{Seco} \%)$. A variância foi obtida pela seguinte equação:

$$
\mathrm{Veco} \%=\frac{\sum\left(\mathrm{eco}_{\mathrm{n}} \%-\overline{\mathrm{eco}}_{\mathrm{n}} \%\right)^{2}}{m-1}
$$


onde :

Veco\% : variância da ecovalência em \%;

$\sum \mathrm{eco}_{\mathrm{n}} \%$ : somatório das eco\% de todos os " $\mathrm{n}$ " caracteres avaliados para o genótipo "i";

$\overline{\mathrm{eco}}_{\mathrm{u}} \%$ : média das eco\% de todos os "n" caracteres avaliados para o genótipo "i";

$\mathrm{m}$ : número total de caracteres avaliados;

As análises estatístico-genéticas para obtenção das ecovalências $\left(\mathrm{eco}_{\mathrm{i}}\right)$ e ecovalência em porcentagem (eco\%) foram realizadas utilizando-se o programa computacional GENES (Cruz, 1997). O teste de significância da ecovalência e a obtenção das médias, variâncias e desvios padrões da ecovalência foram obtidos através do programa computacional EXCEL para Windows 98.

\subsubsection{Análise de médias e desvios padrões}

Para testar a potencialidade dos cruzamentos óctuplos nas progênies de soja, foram realizadas comparações de médias e desvios padrões entre as progênies destes cruzamentos e as testemunhas utilizadas em cada ciclo de maturação (precoce, semiprecoce, intermediário e semi-tardio). Os cálculos de médias e desvios padrões foram efetuados para todos os ciclos de maturação e caracteres avaliados.

As médias de cada tratamento em cada ambiente avaliado foram obtidas pela soma dos valores de cada repetição e, posteriormente, dividindo-se este valor pelo número de repetições. As médias gerais obtidas para cada tratamento foram calculadas a partir do somatório das médias de cada ambiente avaliado, sendo depois este total dividido pelo número de ambientes avaliados. $\mathrm{O}$ cálculo foi feito pela seguinte fórmula:

$$
M_{G}=\frac{\sum M_{1}}{L}
$$


onde:

$\mathrm{M}_{\mathrm{G}}$ : média geral do genótipo nos ambientes avaliados;

$\sum \mathrm{M}_{1}$ : somatório das médias do genótipo em cada ambiente "l"; sendo $1=1, \ldots, \mathrm{L}$;

$\mathrm{L}$ : número de locais avaliados;

Foi utilizado o Teste de Dunnett ao nível de $5 \%$ de probabilidade para a comparação da média geral de cada progênie $\left(\mathrm{M}_{\mathrm{G}}\right)$ com a média das testemunhas, na tentativa de detectar progênies diferenciadas das testemunhas utilizadas para cada ciclo de maturação e para cada um dos seis caracteres avaliados. Outra comparação realizada foi entre a média de cada progênie obtida para os seis ambientes testados $\left(\mathrm{M}_{\mathrm{G}}\right)$, com a média geral de todas as progênies $(\mathrm{Mp})$ para se avaliar a posição de cada progênie na classificação geral (\%PGp). Para esta finalidade, utilizou-se a seguinte fórmula:

$$
\% \mathrm{PG}_{\mathrm{p}}=\frac{\mathrm{M}_{\mathrm{G}}}{\mathrm{M}_{\mathrm{p}}}
$$

onde:

$\% \mathrm{PG}_{\mathrm{p}}$ : valor comparativo entre cada progênie e a média das progênies;

$\mathrm{M}_{\mathrm{G}}$ : média geral da progênie nos ambientes avaliados;

$\mathrm{Mp}$ : média geral de todas as progênies;

O mesmo cálculo foi realizado, porém, comparando-se a média de cada progênie nos ambientes com a média geral das testemunhas $(\mathrm{Mt})$, de modo a avaliar se o ganho obtido foi positivo ou negativo (\%PGt) em relação aos padrões experimentais. Para este cálculo, usou-se a fórmula:

$$
\% \mathrm{PG}_{\mathfrak{t}}=\frac{\mathrm{M}_{\mathrm{G}}}{\mathrm{M}_{\mathrm{t}}}
$$


onde:

$\% \mathrm{PGt}$ : valor comparativo entre cada progênie e a média das testemunhas;

$\mathrm{M}_{\mathrm{G}}$ : média geral da progênie nos ambientes avaliados;

Mt : média geral de todas as testemunhas;

Espera-se obter uma maior variabilidade genética nas progênies (cruzamentos óctuplos), do que nas testemunhas (cruzamentos biparentais). A maior variabilidade genética das progênies, comparadas às testemunhas, comprovará a eficácia dos cruzamentos múltiplos no aumento da variabilidade em soja. Tal fato sugere que podem surgir progênies com uma maior base genética do que as existentes, o que consiste no objetivo básico do programa de melhoramento de soja através de seleção recorrente. A obtenção de desvio padrão, associado a uma maior ou menor média, também auxiliará nas observações com relação à estabilidade fenotípica. Ou seja, o esperado é que as progênies com menores desvios padrões, teoricamente sejam as mais estáveis e preferencialmente tenham as maiores médias, enquanto que, por outro lado, aquelas menos estáveis, possuam maiores desvios e sejam menos produtivas.

\subsubsection{Correlações entre caracteres}

Existem várias formas de se realizar o estudo de correlação, podendo estas serem calculadas por geração individual (Gomes, 1995; Azevedo Filho, 1997), pelo agrupamento das gerações avaliadas (Gomes, 1995; Azevedo Filho, 1997), por dados de plantas individuais (Lopes, 1996), por dados de parcela (Yokomizo, 1994), por locais individuais (Laínez-Mejía, 1996; Yokomizo, 1999), por dados de análise conjunta (Laínez-Mejia, 1996; Yokomizo, 1999; Pinheiro, 1998) ou mesmo por cruzamento efetuado (Pinheiro, 1998).

No presente estudo, as correlações foram calculadas utilizando-se os dados das três gerações estudadas $\left(F_{4: 3[8]} ; F_{5: 3[8]}\right.$ e $\left.F_{6: 3[8]}\right)$ conjuntamente, ou seja, para um total de seis experimentos instalados, tomando-se os dados das progênies. Os tipos de correlações estudados foram a genética $\left(\mathrm{r}_{\mathrm{G}}\right)$ e a fenotípica $\left(\mathrm{r}_{\mathrm{F}}\right)$ de Pearson, sendo 
calculadas pelas combinações de todos os caracteres avaliados (NDM, APM, Ac, VA, CHS e PG) dois a dois. Para a correlação fenotípica de Pearson, além das progênies, realizou-se também os cálculos para o grupo das testemunhas.

Os coeficientes de correlação fenotípica $\left(\mathrm{r}_{\mathrm{F}}\right)$ e genética $\left(\mathrm{r}_{\mathrm{G}}\right)$ foram calculados com base nas seguintes equações, segundo Vencovsky \& Barriga (1992):

Correlação fenotípica :

$\mathrm{rF}(\mathrm{XY})=\frac{\mathrm{COV}_{\mathrm{F}(\mathrm{XY})}}{\sqrt{\mathrm{V}_{\mathrm{F}(\mathrm{X})} \mathrm{V}_{\mathrm{F}(\mathrm{Y})}}}$

onde:

$$
\begin{array}{lc}
r_{F(X Y)}: & \text { correlação fenotípica entre os caracteres } X \text { e } Y ; \\
\operatorname{COV}_{\mathrm{F}(\mathrm{XY})}: & \text { covariância entre os caracteres } \mathrm{X} \text { e } \mathrm{Y} ; \\
\mathrm{V}_{\mathrm{F}(\mathrm{X})} \text { e } \mathrm{V}_{\mathrm{F}(\mathrm{Y})}: \text { variância fenotípica de tratamentos para os caracteres } \mathrm{X} \text { e } \mathrm{Y} .
\end{array}
$$

Correlação genética ou genotípica :

$$
\mathrm{r}_{\mathrm{G}(X Y)}=\frac{\operatorname{COV}_{\mathrm{G}(X Y)}}{\sqrt{V_{G(X)} V_{G(Y)}}}
$$

onde:

$$
\begin{array}{ll}
\mathrm{r}_{\mathrm{G}(X Y)}: & \text { correlação genética entre os caracteres } \mathrm{X} \text { e } \mathrm{Y} ; \\
\mathrm{COV}_{\mathrm{G}(\mathrm{XY})}: & \text { covariância entre os caracteres } \mathrm{X} \text { e } \mathrm{Y} ; \\
\mathrm{V}_{\mathrm{G}(\mathrm{X})} \text { e } \mathrm{V}_{\mathrm{G}(\mathrm{Y})} \text { : variância genética de tratamentos para os caracteres } \mathrm{X} \text { e } \mathrm{Y} .
\end{array}
$$

Para ambas as equações apresentadas, antes de se efetuar o cálculo da covariância, é necessário que se faça uma análise de variância composta $(X+Y)$ dos 
caracteres envolvidos na correlação (Kempthorne, 1973). Esta variância composta pode ser feita da mesma forma que é feita cada análise de variância para $\mathrm{X}$ e $\mathrm{Y}$ isoladamente. Dessa forma, a estimativa da covariância, seja para o cálculo da correlação fenotípica ou genética, pode ser obtida pela seguinte equação:

$\operatorname{COV}_{(X Y)}=\frac{\left[V_{(X+Y)}-V_{(X)}-V_{(Y)}\right]}{2}$

onde:

$\mathrm{V}_{(\mathrm{X}+\mathrm{Y})}$ : variância da soma das observações dos caracteres $\mathrm{X}$ e $\mathrm{Y}$. 


\section{RESULTADOS E DISCUSSÃo}

\subsection{Considerações iniciais}

As semeaduras dos seis experimentos distribuídos em três locais e três anos agrícolas ocorreu no mês de novembro. Dessa forma, o cultivo sempre foi feito no período de verão, considerado período ideal para o cultivo da soja no Estado de São Paulo. Os fatores ambientais, tais como, fotoperíodo, temperatura, umidade relativa e pluviosidade, ocorreram em média dentro das faixas consideradas normais para a cultura. Tais dados podem ser observados no Apêndice 3 .

Todas as observações foram relativas aos ciclos de maturação (CM) separadamente, de acordo com as respectivas siglas: ciclo de maturação precoce (CMP), ciclo semi-precoce (CMSP), ciclo intermediário (CMI) e ciclo semi-tardio (CMST); as progênies (progênie) de cada ciclo foram tratadas como PPR, PSP, PIN e PST.

Devido a problemas ocorridos durante a execução dos experimentos, algumas poucas parcelas foram perdidas, sendo na grande maioria para o caráter produtividade de grãos. Os experimentos e as respectivas parcelas foram: CMP - ESALQ 1995/96, três parcelas de progênies e duas de testemunhas para $P G$, uma parcela de testemunha para NDM, APM, Ac, VA e CHS; CMI - ESALQ 1995/96, dez parcelas de progênies e uma de testemunha para PG; CMST - ESALQ 1995/96, seis parcelas de progênies para PG; CMI - Anhembi 1996/97, duas parcelas de progênies para PG; CMST - Anhembi 1996/97, uma parcela de progènie para PG; CMI - ESALQ 1997/98, uma parcela perdida de progênie para $P G$. 
Conforme observado, para os caracteres NDM, APM, Ac, VA e CHS, ocorreu perda de somente uma parcela no experimento CMP - ESALQ 1995/96, no total de seis experimentos conduzidos nos três anos. Para compensar as perdas de parcelas ocorridas, as análises foram realizadas utilizando-se o procedimento GLM (modelo linear geral) do SAS, onde é feito o ajuste da média em função da perda de observações. Fato similar ocorreu no trabalho realizado por Rocha (1998) onde foi adotado o mesmo procedimento.

\subsection{Análise de resíduos}

De acordo com as análises de resíduos realizadas para todos os $\mathrm{CM}$, verificou-se que não ocorreram dados discrepantes ou "outliers" para os caracteres analisados (NDM, APM, Ac, VA, CHS ou PG). A dispersão dos dados foi visualizada pela análise gráfica, tendo como limite máximo a dispersão de +3 ou -3 vezes o desvio padrão. Este limite é considerado o mais adequado de acordo com o trabalho realizado por Parente (1984). O caráter PG sofreu transformação de g/parcela para kg/há; já os caracteres Ac, VA e CHS sofreram transformação para $\sqrt{\mathrm{x}+0,5}$, conforme já mencionado, pois foram avaliados seguindo uma escala de notas de 1 a 5 (Ac e VA) e de 1 a 4 (CHS). Essa transformação garantiu uma aproximação dos dados à distribuição normal, colocando os mesmos dentro dos limites adequados da análise gráfica. Com este processo, obteve-se também homogeneidade das variâncias e normalidade dos resíduos, permitindo assim, a continuidade das análises. De acordo com Parente (1984), nesta situação, a transformação dos dados é mais eficaz do que a própria substituição do dado discrepante ("outlier") pelo valor sugerido (predito). Um exemplo de análise gráfica realizada para o caráter PG pode ser visualizado na Figura 2.

\subsection{Análise de variância para testemunhas}

As análises de testemunhas foram realizadas com o objetivo principal de avaliar o efeito de conjuntos experimentais dentro dos blocos, podendo-se dessa forma, verificar 
a uniformidade ambiental dentro das repetições. Foram considerados como tratamentos apenas as testemunhas que eram comuns de um conjunto para o outro. De acordo com Gomes (1991), este delineamento pode causar uma redução no desvio padrão do resíduo, melhorando assim a precisão experimental.

Foram realizadas análises individuais (por local), conjunta dos experimentos dentro de cada ano e conjunta entre todos os locais e anos avaliados.

De modo a facilitar a denominação dos locais dos experimentos ou ambientes, optou-se pelo uso de abreviações destes, sendo então : ESALQ 1995/96 (ESA 95/6), ESALQ 1996/97 (ESA 96/7), Anhembi 1996/97 (ANH 96/7), Anhembi 1997/98 (ANH 97/8), ESALQ 1997/98 (ESA 97/8) e Areão 1997/98 (ARE 97/8).

\subsubsection{Análise individual de testemunhas}

De acordo com o total de seis experimentos instalados, foram realizadas as respectivas análises individuais de testemunhas para todos os caracteres em cada $\mathrm{CM}$. Para o CMP (Tabela 1) não foi detectado efeito significativo de conjuntos para nenhum dos caracteres avaliados. No CMSP foi detectada significância a 5\% de probabilidade pelo teste F para o caráter VA no experimento Anhembi (1996/97). Faz-se necessário lembrar que para este grupo, foram realizadas cinco análises individuais pelo fato de não existir a classificação de CMSP no ano agrícola 1995/96, conforme pode ser observado na Tabela 2. Para o CMI, foi detectada significância somente ao nível de $5 \%$ de probabilidade, para o caráter NDM nos locais ESALQ 1996/97 e Anhembi 1996/97, e para o caráter APM no local Anhembi 1996/97 (Tabela 3). Para o CMST, efeito significativo de conjuntos foi observado para o caráter NDM no local ESALQ 1995/96 e para o caráter APM no local ESALQ 1996/97, sendo ambos ao nível de 5\% de probabilidade (Tabela 4).

No total, dos 133 quadrados médios que envolveram o efeito de conjuntos e suas interações nestas análises individuais, apenas seis foram significativos, sendo esta significância somente ao nível de $5 \%$ de probabilidade. Isto equivale dizer que apenas 
$4,51 \%$ do total dos quadrados médios apresentaram significância para o efeito de conjuntos na análise individual de testemunhas, sendo considerado um baixo percentual.

\subsubsection{Análise de testemunhas por ano}

As análises por ano incluíram todos os experimentos instalados dentro de cada ano, para cada CM separadamente. Lembrando que, para o ano agrícola 1995/96 a análise por ano e individual por local constituem a mesma, pois neste ano a instalação de experimentos ocorreu em somente um local devido ao pequeno número de sementes disponivel.

Os resultados do CMP apresentaram ausência de significância para as fontes de variação "conjuntos dentro de locais" (C / L ) e "conjuntos x testemunhas" (C x T), as quais testaram o efeito de conjuntos (Tabela 5). Tais resultados foram observados para todos os caracteres avaliados, tanto no ano agrícola 1996/97 que incluiu análise de dois ambientes, como no ano agrícola 1997/98 que incluiu três ambientes. $\mathrm{Na}$ análise do ano agrícola 1996/97 para o CMSP, também não foram detectadas significâncias em nenhuma das duas fontes testadoras para o efeito de conjuntos, porém no ano 1997/98 detectou-se significância a $5 \%$ de probabilidade da fonte $\mathrm{C} \times \mathrm{T}$ para o caráter NDM, conforme apresentado na Tabela 6. Com relação ao CMI para o ano 1996/97, detectouse significância também ao nivel de $5 \%$ da fonte C / L para os caracteres NDM e APM. Entretanto, no ano 1997/98 ambas as fontes testadoras de conjuntos não apresentaram significância, conforme pode ser visto na Tabela 7. Para o CMST, constatou-se significância do desdobramento C / L ao nível de 5\% para os caracteres APM (1996/97) e NDM (1997/98); sendo que no último ano, detectou-se também a mesma significância $(5 \%)$ da interação C $\times$ T para NDM (Tabela 8).

Sendo assim, dos 96 quadrados médios testados que envolviam o efeito de conjuntos e suas interações, apenas seis foram significativos, ainda que ao nivel de $5 \%$ de probabilidade. Ou seja, detectou-se significância em apenas $6,25 \%$ do total de quadrados médios para tal efeito, sendo também considerado um baixo percentual, reforçando a tendência antes observada nas análises individuais. 


\subsubsection{Análise de testemunhas conjunta}

As análises conjuntas (locais e anos) foram realizadas para todos os caracteres e CM, através da reunião dos seis experimentos para CMP; CMI e CMST, e cinco experimentos no caso do CMSP. A fonte testadora do efeito de conjuntos foi o desdobramento "conjunto dentro de locais dentro de anos" (C / L / A). Nos resultados obtidos do CMP e CMSP não foi detectada significância da fonte envolvendo conjuntos para nenhum dos caracteres avaliados, como pode ser observado nas Tabelas 9 e 10, respectivamente. Para o $\mathrm{CMI}$, uma significância ao nível de $5 \%$ pelo teste $\mathrm{F}$ da referida fonte foi detectada para os caracteres NDM e APM (Tabela 11). A mesma significância foi observada no CMST para os caracteres APM e VA, e uma maior significância (1\%) para o caráter CHS foi detectada no mesmo ciclo. A alta significância ao nível de $1 \%$ para o caráter CHS já era esperada, pois o CMST foi aquele com maior incidência de cancro-da-haste, fato que contribuiu para a significância de quase todas as fontes de variância presentes na análise conjunta, como pode ser observado na Tabela 12.

Para a análise conjunta, do total de 24 quadrados médios que mediram o efeito de conjuntos e suas interações, cinco apresentaram significância, sendo quatro deles a $5 \% \mathrm{e}$ apenas um a $1 \%$ de significância, perfazendo $20,8 \%$ dos quadrados médios totais da análise conjunta.

De forma geral, dos 253 quadrados médios analisados, apenas 17 mostraram significância, sendo 16 deles a $5 \%$ e somente um a $1 \%$. Isto significa que apenas $6,71 \%$ do total geral de quadrados médios, incluindo as três análises, foi significativo. Com relação aos caracteres analisados, do total dos 17 quadrados médios significativos, oito eram relativos a NDM, seis eram referentes ao caráter APM, dois a VA e um ao CHS. Portanto, o caráter mais afetado foi NDM. O caráter considerado de maior importância, ou seja, PG, não apresentou significância para os seus quadrados médios em nenhuma das três análises realizadas para testemunhas. O baixo percentual de quadrados médios significativos detectados, aliado a grande ausência de significância das fontes importantes ( $\mathrm{C} \times \mathrm{T}$ e $\mathrm{C} / \mathrm{L})$, permite considerar que a estratificação das repetições em conjuntos experimentais não exerceu maiores efeitos no delineamento experimental. 
Desta forma, torna-se desnecessário o ajuste de médias, podendo-se realizar as análises seguintes pelo modelo de blocos ao acaso. Outros trabalhos optaram pela mesma decisão devido à pequena quantidade e magnitude das significâncias dos quadrados médios encontrados relativos aos efeitos de conjuntos (Soldini, 1993; Hiromoto, 1996; Azevedo Filho, 1997; Rocha, 1998 e Yokomizo, 1999).

\subsection{Análise de variância para progênies}

As análises de variância para progênies foram realizadas para cada local (análise individual), conjunta dentro de cada ano e conjunta entre locais e anos, para todos os caracteres avaliados. O objetivo principal das análises individuais é verificar se existe diferença entre os genótipos avaliados e consequentemente se existe variabilidade genética suficiente para o processo de seleção. Com relação às análises conjunta por ano e conjunta total, o principal intuito é verificar a possivel existência de interações genótipos $\mathrm{x}$ ambientes, o efeito dos diferentes anos e ainda o comportamento dos diferentes locais quando avaliados em diferentes anos agrícolas, através das fontes de variação e dos desdobramentos utilizados na análise de variância. Tais informações também são importantes para orientar a realização da análise de estabilidade fenotípica das progênies.

\subsubsection{Análise individual de progênies}

Para o primeiro ano (1995/96) a análise de variância individual seguiu o modelo de blocos aumentados de Federer,. Para os anos seguintes (1996/97 e 1997/98) as análises individuais seguiram o modelo de blocos ao acaso, já que não foi detectado efeito significativo de conjuntos nas análises de testemunhas. 


\subsubsection{Análise em blocos aumentados}

Esta análise foi realizada para cada $\mathrm{CM}$ e para cada caráter no ambiente ESA $95 / 6$.

Como o delineamento de blocos aumentados é caracterizado por não apresentar repetições, o resíduo foi estimado a partir das testemunhas, as quais eram comuns dentro de cada $\mathrm{CM}$ e repetidas em todos os conjuntos. Os conjuntos foram considerados como repetições ou blocos no esquema de análise de variância (Apêndice 9) e o erro obtido foi denominado de intrablocos.

Os quadrados médios obtidos na análise de variância em blocos aumentados, as médias gerais e os coeficientes de variação (CV\%) para o CMP, CMI e CMST, para todos os caracteres avaliados encontram-se na Tabela 13 .

Detectou-se diferenças significativas entre os genótipos do CMP (233 progènies e quatro testemunhas) pelo teste $\mathrm{F}$ ao nível de $1 \%$ para o caráter NDM e a $5 \%$ para os outros caracteres exceto PG. Entre as progênies, diferenças foram detectadas para NDM a $1 \%$ e para APM, Ac, VA e PG ao nivel de $5 \%$. As testemunhas não diferiram entre si para nenhum dos caracteres avaliados, enquanto que o contraste progênies vs testemunhas ( $\mathrm{P}$ vs $\mathrm{T}$ ) foi significativo ao nivel de $1 \%$ somente para NDM.

Foram encontradas diferenças entre as 352 progènies do $\mathrm{CMI}$ ao nivel de $1 \%$ de significância para NDM e CHS, e a 5\% para APM, Ac e PG. Porém, para o caráter VA, as progênies não diferiram entre si. Fato similar ocorreu entre os genótipos para os caracteres NDM, CHS, APM, Ac e VA, no entanto, estes não diferiram quanto à PG. As testemunhas diferiram entre si somente para o caráter NDM ao nível de $1 \%$, enquanto que para o contraste $P$ vs $T$ não houve diferença significativa para nenhum dos caracteres.

Nos resultados obtidos na análise do CMST, tanto na fonte de variação de genótipos quanto para o desdobramento de progênies, que totalizavam 140, observou-se diferenças significativas para os caracteres NDM e APM ao nível de $1 \%$ e $5 \%$ respectivamente. Para os caracteres Ac, VA e PG, as fontes de genótipos e progênies não foram significativas. As testemunhas, por sua vez, não se diferenciaram para nenhum 
dos caracteres avaliados. O contraste $\mathrm{P}$ vs $\mathrm{T}$ foi altamente significativo (1\%) somente para o caráter NDM.

As diferenças significativas existentes entre as progênies para todos os caracteres avaliados no CMP e para quase todos no CMI (exceto VA), indica que a variabilidade existe entre elas, o que sugere a possibilidade de sucessos com a seleção. No CMST a variabilidade foi detectada somente para NDM e APM. As médias para NDM, APM, Ac e VA entre os diferentes CM não variou muito como era esperado, sugerindo que os grupos realmente estavam homogêneos entre eles. Novos reagrupamentos, principalmente para ciclo foram realizados para detectar uma maior diferenciação entre os grupos, havendo também a inclusão do CMSP para a próxima geração, que não estava presente nesta safra. Todos os CM apresentaram altas médias de PG, sendo todas acima de $3200 \mathrm{~kg} / \mathrm{ha}$. Isto se explica pelo alto potencial produtivo das progênies, além do favorecimento das parcelas na geração $F_{4: 3[8]}$, que dispôs de uma fileira livre entre uma parcela e outra para o crescimento.

Os coeficientes de variação (CV\%) dos experimentos para todos os CM avaliados indicam que ocorreu uma maior precisão experimental para o caráter NDM, o qual apresentou valores muito baixos $(0,84$ a $2,22 \%)$, seguido do caráter VA $(5,20$ a 6,62\%), enquanto APM e Ac apresentaram valores intermediários (11,37 a 12,93\% e 12,12 a $17,94 \%$, respectivamente). O caráter $\mathrm{PG}$ apresentou CV's médios $(13,15$ a $16,84 \%)$ considerando a sua natureza quantitativa e altamente variável. Estes valores evidenciam que os experimentos apresentaram boa precisão para este caráter. Dados concordantes com relação aos CV's dos caracteres e suas classificações quanto às precisões experimentais foram encontrados por Gomes (1995) e Azevedo Filho (1997).

\subsubsection{Análise em blocos ao acaso}

As análises individuais em blocos ao acaso foram realizadas para os cinco ambientes entre os anos de 1996/97 e 1997/98.

O objetivo principal desta análise foi investigar a existência de variabilidade entre as progênies. Assim, somente esta fonte de variação foi utilizada para tratamentos 
na análise de variância. Esta análise foi separada por ciclo e por caráter. Os valores e significâncias dos quadrados médios, as médias gerais e os coeficientes de variação ( $\mathrm{CV \% )} \mathrm{para} \mathrm{todos} \mathrm{os} \mathrm{caracteres} \mathrm{avaliados} \mathrm{nas} \mathrm{progênies} \mathrm{PPR,} \mathrm{PSP,} \mathrm{PIN} \mathrm{e} \mathrm{PST} \mathrm{são}$ apresentados nas Tabelas 14, 15, 16 e 17, respectivamente. Cada tabela contém os ambientes utilizados para cada $\mathrm{CM}$; pode-se notar que o número de progênies sofreu redução de um ano para o outro, devido à seleção praticada em cada geração conduzida.

Nos resultados obtidos das 17 progènies PPR testadas em 1996/97 e 1997/98 detectou-se diferenças significativas ao nível de $1 \%$ pelo teste F para NDM e APM em todos os ambientes avaliados. Para o caráter Ac ocorreram diferenças entre as progênies a $1 \%$ nos ambientes ESA 96/7, ANH 97/8 e ESA 97/8, e a 5\% em ARE 97/8, e nenhuma diferença em ANH 96/7. Para o caráter VA, nenhuma diferença foi observada entre as PPR nos ambientes ESA 96/7, ANH 96/7 e ARE 97/8, porém em ESA 97/8 as diferenças foram significativas (5\%) e em ANH 97/8 altamente significativas (1\%). As PPR não se distinguiram quanto à reação ao CHS nos ambientes ESA 96/7 e ESA 97/8, se distinguiram nos ambientes ANH 96/7 e ANH 97/8 a 5\% e 1\%, respectivamente; já no ambiente ARE $97 / 8$ não se verificou a ocorrência desta doença nestas progênies. Com relação ao caráter PG, as PPR diferenciaram-se significativamente (5\%) nos ambientes ANH 96/7 e ESA 97/8, não ocorrendo diferenças entre elas nos demais ambientes avaliados. Para PG, destacou-se ESA 96/7, com a maior média (2648 kg/ha) seguido de ESA 97/8 e ANH 97/8 (Tabela 14).

Para o CMSP, as 57 progênies de $1996 / 97$ e as 30 progênies de 1997/98 que foram testadas comportaram-se diferentemente para o caráter NDM e Ac ao nível de 1\% de significância em todos os ambientes; para o caráter APM ocorreu o mesmo, exceção feita ao ambiente ESA $97 / 8$ onde não se detectou nenhuma diferença entre as mesmas. As PSP diferiram entre si também para o caráter VA a um nível de $5 \%$ de significância nos ambientes ESA 96/7 e ESA 97/8 e a 1\% no ANH 96/7, porém para os ambientes ANH 97/8 e ARE 97/8 elas não se distinguiram. Os ambientes ESA 96/7, ANH 96/7, ANH 97/8 e ARE 97/8 discriminaram bem as progênies PSP para reação ao CHS, sendo os dois primeiros ao nível de $1 \%$ e os outros dois a $5 \%$; por sua vez, o ambiente ESA $97 / 8$ não discriminou as progênies, embora tenha tido a maior média geral $(1,55)$ para 
CHS. Para PG, diferenças altamente significativas a $1 \%$ foram detectadas nos ambientes ESA 96/7, ANH 96/7 e ANH 97/8, e ao nível de 5\% no ambiente ESA 97/8; apenas no ARE 97/8 não houve diferenças entre PSP (Tabela 15).

Os quadrados médios obtidos nas análises das 179 progênies do CI de 1996/97 e das 60 progênies testadas em 1997/98 apresentaram uma alta significância ao nível de $1 \%$ para os caracteres NDM, APM, Ac e VA em todos os cinco ambientes avaliados. Para reação ao CHS ocorreu o mesmo, exceto no ambiente ARE 97/8, onde a significância foi ao nivel de 5\%. O caráter PG foi bem discriminado entre as progênies ao nível de 1\% nos ambientes ESA 96/7, ANH 96/7, ESA 97/8 e ARE 97/8, porém não se detectou diferença entre as progênies no ambiente ANH 97/8 (Tabela 16)

O CMST foi composto por 60 progênies no ano 1996/97 e 20 progênies no ano 1997/98. Foram detectadas diferenças altamente significativas (1\%) nos ambientes ESA 96/7, ANH 96/7, ESA 97/8 e ARE 97/8 para o caráter NDM, e diferenças significativas (5\%) no ambiente ANH 97/8. Para o caráter APM, as progênies diferenciaram-se significativamente ao nível de 1\% somente nos ambientes ESA 96/7, ANH 96/7 e ARE 97/8; e ao nível de 5\% no ambiente ESA 97/8. As PST comportaram-se de forma semelhante para Ac e VA em todos os ambientes, ou seja, detectou-se diferenças altamente significativas nos ambientes ESA 96/7, ANH 96/7, ANH 97/8 e ESA 97/8, e nenhuma diferença em ARE 97/8. Houve diferenças quanto à reação ao CHS somente nos ambientes ESA 96/7 e ANH 97/8, porém ao nível de 1\%. O comportamento das PST foi similar em todos os ambientes para o carater PG, dessa forma nenhum ambiente foi discriminador para tal caráter (Tabela 17).

As significâncias presentes nos efeitos de progênies sugere a disponibilidade de variabilidade para todos os caracteres avaliados em todos os $\mathrm{CM}$, destacando-se os caracteres NDM e APM que apresentaram significância em todos os ambientes, para as PPR e PIN e em quase todos os ambientes nas PSP e PST. As altas significâncias para NDM indicam que este caráter ainda apresenta bastante variabilidade dentro do agrupamento feito por ciclo de maturação, sendo necessário um novo agrupamento para NDM nas progênies que forem selecionadas. Isto já era esperado, pois os parentais eram bastante divergentes para $\mathrm{CM}$ (cruzamentos óctuplos), e existem pelo menos seis genes 
envolvidos na sua herança (Bernard, 1971; Buzzell, 1971; Buzzell \& Voldeng, 1980; Mc Blain \& Bernard, 1987; Bonato \& Vello, 1999b). As maiores médias para NDM e APM, conforme esperado, foi para as PIN e PST devido ao fato dessas progennies apresentarem maior CM. O caráter Ac foi significativo para todos os ambientes nos CMSP e CMI; já nos CMP e CMST, as progênies diferiram em quatro dos cinco ambientes. As maiores médias de Ac tiveram uma tendência de acompanharem as maiores médias de APM; isto pode ser devido ao fato de plantas mais altas serem mais sujeitas ao acamamento (Yokomizo, 1999). As PIN e PST, foram mais discriminadas para VA do que as progênies de ciclo mais precoce. No entanto, as médias de VA tenderam a decrescer com o aumento do $\mathrm{CM}$, talvez devido a maior exposição das progênies mais tardias aos fatores ambientais desfavoráveis, reduzindo a nota visual do genótipo. O contrário ocorreu para PG, pois somente as PST não se diferenciaram para este caráter, ao passo que todas as outras progênies de $\mathrm{CM}$ mais curto puderam ser discriminadas em alguns ambientes. As médias de PG foram variáveis em todos os $\mathrm{CM}$, porém seguiram a tendência esperada de maiores médias com o aumento do $\mathrm{CM}$, sendo estas encontradas nos ambientes ANH 97/8 e ARE 97/8 para as PIN e PST, respectivamente. Tal fato, deve-se principalmente a uma maior altura média, e com isso, um maior número de internódios produtivos. Para o CHS, as PIN apresentaram diferenças significativas entre progênies e em um maior número de ambientes que os outros $\mathrm{CM}$.

A diferença das significâncias das progênies avaliadas, de um ambiente para o outro, para um mesmo caráter, evidencia um comportamento diferenciado destes genótipos nos vários ambientes. De acordo com Soldini (1993) e Rocha (1998), a presença de variabilidade entre as progênies indica que estas poderão ser selecionadas pelos seus desempenhos médios nos vários locais de avaliação ou, pelas superioridades quando comparadas à melhor testemunha padrão em um ou vários locais.

Os CV's obtidos nas análises de blocos ao acaso acompanhou a tendência antes observada nas análises de blocos aumentados. Maiores precisões experimentais (menores CV's) foram exibidos pelos caracteres NDM $(0,63$ a 2,21\%) e VA $(3,93$ a 8,84\%); precisões intermediárias foram observadas em Ac $(6,42$ a 17,25\%), CHS(5,84 a $19,43 \%)$ e APM (8,63 a 20,03\%);e menor precisão média ocorreu para PG $(13,94$ a 
$27,05 \%$ ). Estes valores observados, são considerados aceitáveis e concordam com os resultados de outros trabalhos realizados (Soldini, 1993; Farias Neto, 1995; LaínezMejía, 1996; Rocha, 1998 e Yokomizo, 1999). Com isto, pode-se considerar que houve maior precisão experimental para NDM e VA, e uma menor precisão para APM e PG. Quanto a PG, observou-se que os experimentos com maiores valores de CV's para este caráter, também possuíam CV's altos para CHS, podendo ser a ocorrência da doença CHS um fator de grande influência, já que PG é um caráter quantitativo e por isso muito influenciável pelo ambiente.

No ano 1996/97 o ambiente ESA $96 / 7$ mostrou-se mais favorável do que o ambiente ANH 96/7, para a maioria dos caracteres, por ter apresentado menores valores de CV's em quase todos os CM, principalmente para o caráter PG, com exceção do CMST onde a situação foi inversa. No ano 1997/98 o ambiente ANH 97/8 apresentou melhor qualidade para os experimentos, pois nele foram obtidos quase sempre os menores CV's para todos os caracteres e em todos os CM. Para PG, esta situação ocorreu em todos os ciclos, com menores valores de CV's no ambiente ANH 97/8 e maiores em ARE 97/8. Para CHS, os menores valores também foram encontrados em ANH 97/8, porém os maiores valores foram os do ESA 97/8, devido a uma maior incidência da doença neste local, principalmente pelo fato dos experimentos terem sido instalados em áreas com ocorrência prévia da doença. Isto também explica as médias de PG, pois eram esperadas médias maiores no ambiente ESA $97 / 8$ devido a sua maior fertilidade natural, porém isto ocorreu somente no CMP; nos demais ciclos, as médias maiores foram sempre do ambiente ANH 97/8, onde as médias de CHS foram menores que o ESA 97/8, sugerindo uma forte associação da redução de PG nas progênies com maior incidência de CHS.

\subsubsection{Análise de progênies por ano}

As análises conjuntas por ano foram realizadas através do agrupamento dos experimentos instalados dentro de cada ano agrícola. Estas análises foram realizadas individualmente para cada combinação de $\mathrm{CM}$ e caráter. $\mathrm{O}$ objetivo principal desta 
análise foi verificar a existência ou não de interação genótipo $\mathrm{x}$ ambiente para os caracteres em questão, principalmente PG. Os quadrados médios e suas significâncias, médias gerais e coeficientes de variação (CV\%) obtidos em tais análises para o $\mathrm{CMP}$, CMSP, CMI e CMST são apresentados nas Tabelas 18, 19, 20 e 21, respectivamente. Cada tabela contém os dados da análise conjunta do ano de 1996/97 e do ano de 1997/98 relativo a cada CM, para os caracteres NDM, APM, Ac, VA, CHS e PG.

Para que determinados experimentos possam ser agrupados para análise conjunta, Gomes (1991) cita que é necessário que o quociente obtido entre o maior e o menor quadrado médio do resíduo não ultrapasse o valor sete, de acordo com o critério "F máximo" de Hartley (1950). Realizou-se então os agrupamentos dos experimentos, já que os quocientes obtidos tanto para o ano de 1996/97 quanto para 1997/98 situaram-se bem abaixo do limite máximo para todos os caracteres avaliados. $\mathrm{O}$ valor máximo obtido foi 6,22 para o caráter CHS no CMP, permanecendo a grande maioria (77\%) entre os limites de um e três. Os testes de homogeneidade de variâncias para os anos de 1996/97 e 1997/98 podem ser observados na Tabela 41.

$\mathrm{Na}$ análise do ano agrícola $1996 / 97$ para o CMP (Tabela 18), as PPR apresentaram valores significativos a $1 \%$ pelo teste $\mathrm{F}$ para todos os caracteres, exceto para CHS que foi a $5 \%$. As testemunhas foram significativas a $1 \%$ para NDM e APM, a $5 \%$ para VA e PG e não-significativas para Ac e CHS. A comparação entre os grupos através do contraste progênies vs testemunhas ( $\mathrm{P}$ vs $\mathrm{T}$ ) foi significativo para APM, Ac e VA a $1 \%$; para NDM a $5 \%$ e não-significativo para CHS e PG. A principal fonte de variação neste estudo, ou seja, a que mede a interação genótipo $\times$ ambiente ( $\mathrm{G} \times \mathrm{L}$ ) mostrou-se significativa a $1 \%$ para NDM e Ac, a $5 \%$ para PG e CHS e não-significativa para APM e VA.

No ano de 1997/98 também para o CMP, as PPR distinguiram-se entre si ao nível de $1 \%$ de significância para todos os caracteres. As testemunhas, por sua vez, distinguiram-se a $1 \%$ somente para NDM e APM, a $5 \%$ para PG e não diferiram para Ac, VA e CHS. O contraste $\mathrm{P}$ vs $\mathrm{T}$ detectou diferenças entre os grupos somente para VA a $1 \%$ e $\mathrm{CHS}$ a $5 \%$. A interação $\mathrm{G} \times \mathrm{L}$ detectou diferenças significativas para os 
caracteres NDM, Ac e CHS a 1\%; para PG e VA a 5\% e não detectou para APM (Tabela $18)$.

Para os resultados obtidos com o CMSP (Tabela 19) nas análises de 1996/97, as PSP apresentaram significância a 1\% para todos os caracteres. Isto ocorreu também com o grupo das testemunhas, exceção feita somente ao caráter CHS, o qual foi nãosignificativo. A comparação $\mathrm{P}$ vs $\mathrm{T}$ detectou diferenças entre os grupos para APM, VA e PG a 1\%; para NDM a 5\% e nenhuma diferença para Ac e CHS. A interação G $\times$ L foi significativa ao nível de $1 \%$ para NDM, Ac e VA; ao nivel de 5\% de significância para PG e não-significativa para APM e CHS.

As PSP, na análise agrupada de 1997/98 do CMSP (Tabela 19), demonstraram diferenças para todos os caracteres, sendo que os valores foram todos significativos a $1 \%$ para NDM, APM, Ac, VA e CHS; e ao nível de 5\% para PG. As testemunhas comportaram-se como no ano anterior, diferindo a $1 \%$ para todos os caracteres, menos para CHS onde não diferiram. $O$ contraste $P$ vs $T$ não apresentou diferenças significativas para NDM, APM e Ac; porém, detectou-se diferenças altamente significativas para os demais caracteres, nos quais se inclui PG. A interação G $\mathrm{L}$ detectou diferenças em todos os caracteres, exceto para APM, sendo que as diferenças para NDM, Ac, CHS e PG foram a 1\% e para VA ao nível de $5 \%$.

Nos resultados de 1996/97, as PIN diferiram entre si para todos os caracteres avaliados a $1 \%$ de significância pelo teste $\mathrm{F}$. As testemunhas deste $\mathrm{CM}$ não diferiram para NDM, mas diferiram a 1\% para APM, Ac, VA e PG; e a 5\% para CHS. O contraste $\mathrm{P}$ vs $\mathrm{T}$ distinguiu os grupos para todos os caracteres com alta significância (1\%). A fonte de variação $\mathrm{G} \times \mathrm{L}$ não detectou diferenças para NDM e CHS, porém detectou diferenças significativas a $1 \%$ para APM, Ac e VA; e a $5 \%$ para PG (Tabela 20).

$\mathrm{Na}$ análise conjunta de $1997 / 98$, as PIN tiveram seus efeitos significativos a $1 \%$ em todos os seis caracteres avaliados, como na análise do ano anterior. Para o efeito de testemunhas, dos seis caracteres avaliados, cinco deles (NDM, APM, Ac, VA e CHS) foram significativos a $1 \%$; e um (PG) a $5 \%$. No contraste entre os grupos citados, todos os caracteres diferiram ao nível de $1 \%$ de significância, e na interação G x L apenas 
APM não foi significativo, sendo os demais caracteres, todos significativos a $1 \%$, destacando PG (Tabela 20).

Os quadrados médios obtidos na análise agrupada do ano 1996/97 (Tabela 21) mostraram significância a $1 \%$ para as PST em todos os caracteres avaliados. Significância também foi detectada em todos os caracteres para as testemunhas, porém a $5 \%$ para CHS e PG, e a $1 \%$ para os demais. A comparação entre os grupos de genótipos citados através do contraste $P$ vs $T$ conseguiu diferenciar o comportamento dos grupos somente para o caráter Ac a $1 \%$, sendo que para os demais caracteres, o comportamento foi similar para progênies e testemunhas. A interação $\mathrm{G} \times \mathrm{L}$ apresentou diferenças altamente significativas a $1 \%$ para NDM e Ac, e a $5 \%$ para VA e PG, não detectando diferenças para APM e CHS.

Finalmente, o efeito das PST no ano de 1997/98 foi não-significativo apenas para PG, ocorrendo significância a $1 \%$ para os demais caracteres. $O$ efeito de testemunhas foi significativo a $1 \%$ somente para NDM e Ac, não apresentando significância para todos os outros caracteres. $\mathrm{O}$ contraste $\mathrm{P}$ vs $\mathrm{T}$ foi significativo a $1 \%$ para NDM, Ac e VA; a $5 \%$ para PG e não-significativo para APM e CHS. O efeito da interação $\mathrm{G} \times \mathrm{L}$ apresentou significância somente para NDM a $1 \%$ e para PG a 5\%, sendo que os demais caracteres não apresentaram efeitos significativos para tal interação (Tabela 21).

$O$ efeito de locais foi significativo praticamente para todos os caracteres em todos os CM. Não foram detectadas diferenças significativas entre locais apenas para os caracteres VA e CHS na análise do CMP 1996/97; para o caráter Ac nos CMSP e CMI, ambos no ano 1996/97 e para PG no CMST em 1997/98. Isto pode ser um indicativo de que os locais utilizados são muito variáveis para todos os caracteres avaliados e para todos os CM. Analisando de forma geral, os efeitos de locais foram mais significativos no ano 1997/98 do que no ano 1996/97 para todos os caracteres; talvez devido ao fato de terem sido utilizados três ambientes diferentes em 1997/98 e apenas dois em 1996/97. Outros trabalhos detectaram diferenças para os locais utilizados com vários $\mathrm{CM}$ diferentes, relativos à PG (Toledo et al., 1990; Alliprandini et al., 1994; Duarte et al., 1994) e relativos à NDM, APM, Ac, VA e PG (Rocha, 1998; Yokomizo, 1999). 
De acordo com os resultados obtidos, as diferenças exibidas entre as progênies em todos os $\mathrm{CM}$ e para todos os caracteres avaliados sugere a existência de diferenças genéticas entre elas, já indicada também na análise individual por local. Tais diferenças podem ser devido principalmente à diversidade genética entre os parentais que compõem os diferentes cruzamentos elaborados neste trabalho, gerando uma variabilidade alta entre as progênies, conforme era esperado para os cruzamentos óctuplos. $O$ grupo das testemunhas também se mostrou bastante variável para muitos caracteres em praticamente todos os $\mathrm{CM}$, porém menos do que as progênies, principalmente no CMSP e CMI, o que pode ser aceitável, pois apesar da grande homogeneidade dos genótipos cultivados, entre eles, as genealogias diferem, o que pode gerar essa variabilidade detectada na análise de variância.

A distinção entre os grupos apresentada através da significância do contraste $\mathrm{P}$ vs $\mathrm{T}$ indica que existem diferenças entre os grupos de progênies e testemunhas para a maioria dos caracteres. Entretanto, os caracteres que menos foram diferenciados entre os grupos foram APM e CHS, que em quatro das oito análises agrupadas não apresentaram diferenças significativas.

A significância da interação $G \times$ L observada em grande parte dos caracteres e em todos os $\mathrm{CM}$, indica que os genótipos comportaram-se de forma diferenciada nos diferentes locais avaliados. De acordo com Cruz \& Regazzi (1994), quando isto ocorre, é necessário que a seleção de genótipos seja efetuada para locais específicos, podendo neste processo identificar quais os genótipos que apresentam menor variação. Com relação aos diferentes caracteres, notou-se que alguns foram mais consistentes para as interações em certos CM do que outros. Como por exemplo, o caráter APM apresentou significância para a interação somente no CMI em 1996/97; nos demais anos e CM não ocorreu diferença significativa para APM, ou seja, os genótipos não variaram de forma significativa no porte com a mudança de local e mesmo de um ano para o outro. Por sua vez, o caráter PG foi sempre significativo para $\mathrm{G} \times \mathrm{L}$ em todos os anos e $\mathrm{CM}$. Isto equivale dizer que a produtividade média da parcela foi o carater que mais sofreu influências com locais de cultivo. Outros caracteres variaram, como CHS que foi significativo para a interação somente no CMP, sendo que, nos CMSP e CMI foi 
significativo somente em 1996/97 e no CMST não apresentou significância para nenhum dos anos. Isto pode estar relacionado à severidade da doença, que visualmente, foi maior em 1996/97. Nos ciclos mais diferenciadores (CMSP e CMI) detectou-se diferença entre os genótipos mais e menos reativos à doença CHS, já que o CMST por permanecer mais tempo no campo, expõe-se mais a incidência da doença, deixando seus genótipos pouco diferenciáveis.

Os caracteres NDM e Ac sofreram mais a influência dos locais, não sendo significativos somente para o CMI (1996/97) e para o CMST (1997/98). Isto significa que a seleção para estes caracteres deve ser específica para cada local avaliado. Situação similar ocorreu com VA, para o qual o efeito da interação $\mathrm{G} \times \mathrm{L}$ não apresentou significância apenas no CMP (1996/97) e no CMST (1997/98), sendo os demais CM significativos para todos os anos.

Os valores de CV's obtidos nas análises conjuntas por ano, a exemplo das análises individuais de blocos aumentados e blocos ao acaso, apresentaram menores magnitudes para NDM $(0,94$ a 2,06\%) e VA $(4,81$ a $8,19 \%)$; valores intermediários para $\operatorname{APM}(9,55$ a $15,73 \%)$, Ac $(6,93$ a $13,23 \%)$ e $\operatorname{CHS}(9,82$ a 16,91$)$; e valores mais elevados para PG (18,06 a 24,97\%). Os menores CV's de NDM e APM foram obtidos no CMST; o de VA no CMSP; o de Ac e CHS no CMP; e o de PG no CMI. De acordo com Laínez-Mejia (1996), quanto mais complexa for a herança genética de um caráter, maior a tendência dele apresentar um $\mathrm{CV}$ mais alto, ilustrando com o caráter produtividade de óleo de sementes de soja, o qual possui natureza quantitativa e depende de outros caracteres desta natureza, no caso, porcentagem de óleo e PG. Outra consideração a respeito dos CV's experimentais é feita por Arias (1996) onde o autor relata que o $\mathrm{CV}$ além de medir a precisão experimental, representa a magnitude da média obtida, ou seja, maiores estimativas de CV's seriam obtidas em ensaios com menor média, e não necessariamente com maior erro experimental. Quando o autor obteve as estimativas das correlações entre as médias de produtividade dos ensaios e os respectivos CV's por ano, encontrou na maioria das vezes, correlações altas e negativas, evidenciando a forte associação entre CV's e médias experimentais. Isto pode ser observado nas análises conjuntas por ano (Tabelas 18 a 21), dentro de um mesmo CM; 
de um ano para o outro, pode-se observar a associação entre médias e CV's na quase totalidade dos casos, sendo que para PG, isto ocorreu em todos os $\mathrm{CM}$ e anos.

Uma comparação entre os anos 1996/97 e 1997/98 permite considerar que o segundo ano foi mais favorável para os caracteres PG e APM, pois todos os CM apresentaram menores CV's e também maiores médias, fornecendo dessa forma, ensaios de melhor qualidade experimental. Para os demais caracteres, a situação foi variável entre um ano e outro.

Entre os CM, observou-se menores médias para Ac, APM e NDM no CMP e maiores no CMST. Isto é perfeitamente esperado já que plantas com menores ciclos atingem menores alturas e com isso sofrem menos os efeitos do acamamento, ocorrendo o oposto para as plantas mais tardias. Para o VA, as maiores médias encontradas foram no CMP e CMSP no ano 1996/97; CMP e CMI no ano 1997/98. Para CHS, as maiores médias estiveram presentes no CMST em ambos os anos, tendo esta média se elevado com o aumento do ciclo para cada ano avaliado. O experimento com maior média para PG foi o CMST (2614 kg/ha) no ano 1996/97 e o CMI (2628 kg/ha) em 1997/98.

\subsubsection{Análise conjunta de progênies}

Esta análise foi realizada através do agrupamento de todos os experimentos instalados nos três anos agrícolas, sendo realizada por CM, e para cada caráter avaliado. Como foi realizada seleção de um ano para o outro, com consequente redução do número de tratamentos, somente os genótipos presentes no último ano (1997/98) eram comuns em todos os ambientes ou experimentos. Com relação às testemunhas, entre os anos 1996/97 e 1997/98, havia coincidência total entre as mesmas, porém, algumas destas diferiam das utilizadas no ano de 1995/96. Sendo assim, tomando-se apenas os genótipos comuns nos três anos agrícolas, realizou-se as análises conjuntas entre anos com os seguintes números de tratamentos: 17 progênies e duas testemunhas para o CMP; 30 progênies e duas testemunhas para o CMSP; 60 progênies e três testemunhas para o CMI e 20 progênies e três testemunhas para o CMST. 
O objetivo principal desta análise foi verificar o efeito de anos, dos locais dentro de anos, da interação genótipo $\mathrm{x}$ ambiente entre os anos e também dentro dos anos. A significância das interações genótipo x ambiente, reforçará os resultados da análise por ano, confirmando a utilidade da análise de estabilidade fenotípica dos genótipos na verificação do comportamento diferencial dos mesmos nos vários ambientes avaliados.

A exemplo das análises conjuntas por ano, realizou-se o teste de homogeneidade de variâncias para todos os $\mathrm{CM}$, agora porém confrontando todos os experimentos instalados em todos os anos, testando o limite máximo de sete entre o maior e menor quadrado médio do resíduo, para cada caráter e cada $\mathrm{CM}$. Encontrou-se que $71 \%$ dos valores obtidos situaram-se entre 1 e 4,5, e o maior valor encontrado foi 6,95 para CHS no CMP e CMST. Os testes de homogeneidade de variâncias para a análise conjunta total podem ser observados na Tabela 41.

Os quadrados médios e suas significâncias, bem como as médias e os coeficientes de variação (CV\%), para a análise conjunta entre os anos, ou total, para os CMP, CMSP, CMI e CMST, são apresentados nas Tabelas 22, 23, 24 e 25, respectivamente. Todos os caracteres foram submetidos à análise, para todos os $\mathrm{CM}$.

No CMP (Tabela 22) detectou-se diferenças significativas ao nivel de $1 \%$ para os ambientes pelo teste $\mathrm{F}$, em todos os caracteres avaliados. O efeito de anos também obteve a mesma significância, exceto para o caráter CHS, onde esta foi de $5 \%$. Os locais dentro do ano de 1997/98, indicado nas tabelas por Locais 97 foram significativos para todos os caracteres avaliados, enquanto que os locais dentro do ano de 1996/97 (Locais 96) foram significativos apenas para alguns (NDM, APM, Ac e PG). O local ESALQ, nos três anos avaliados [ESALQ (3 Anos)] diferiu a 1\% para todos os caracteres, e o local Anhembi, nos dois anos [Anhembi ( 2 Anos)] somente não diferiu a 1\% para os caracteres VA e CHS, pois não apresentou significância para estes. As PPR apresentaram diferenças a 1\% para todos os caracteres, porém as testemunhas foram mais homogêneas diferindo apenas para APM a $1 \%$ e para VA a $5 \%$. O efeito da interação genótipo $x$ ambiente ( $G \times E)$, que mediu o comportamento de todos os genótipos (progênies e testemunhas) em todos os experimentos avaliados, foi significativo a $1 \%$ para os caracteres NDM, APM, Ac e CHS; e a $5 \%$ para $P G$, não apresentando significância para VA. A interação de progênies $x$ 
locais para o ano 1996/97 (P x L/96) foi não significativa apenas para VA e PG, detectando para os demais diferenças ao nível de 1\% (NDM e CHS) e 5\% (APM e Ac); já para a interação progênies $x$ locais para o ano 1997/98 (P x L/97), não houve diferenças para APM e PG, enquanto NDM, Ac e CHS diferiram a 1\% e VA a 5\%. Por outro lado, a interação de progênies $x$ anos para a ESALQ ( $P$ x A/ESALQ) foi não-significativa apenas para VA e PG, apresentando significância a $1 \%$ para os demais; e a mesma interação para o local Anhembi (P x A/Anhembi) foi significativa apenas para NDM e CHS a 1\%. A interação tripla progênie $\mathrm{x}$ locais $\mathrm{x}$ anos $(\mathrm{P} \times \mathrm{L} \times \mathrm{A})$ também apresentou significância a $1 \%$ somente para os caracteres NDM e CHS, enquanto a mesma interação tripla para as testemunhas ( $\mathrm{T} \times \mathrm{L} \times \mathrm{A})$ não revelou significância para nenhum dos caracteres avaliados.

Nos resultados obtidos na análise do CMSP (Tabela 23) foram encontradas significâncias a $1 \%$ para todos os caracteres avaliados para o efeito de ambientes, anos e locais dentro do ano 1997/98 (Locais 97). A fonte de variação para os locais avaliados dentro do ano 96 (Locais 96) apresentou significância somente para os caracteres NDM, APM e PG, todos a $1 \%$. O local ESALQ, nos três anos de avaliação foi altamente diferenciador para os caracteres no CMSP, alcançando praticamente a mesma magnitude que o local Anhembi nos dois anos. As progênies distinguiram-se entre si para os caracteres NDM, APM, Ac e VA (1\%) e CHS (5\%), sendo similares para PG. As testemunhas foram diferentes somente para os caracteres NDM, APM e Ac a 1\%. A interação $\mathrm{P} \times \mathrm{L} / 96$ apresentou diferença não-significativa para todos os caracteres, enquanto a interação $\mathrm{P} \times \mathrm{L} / 97$ foi altamente significativa (1\%) para todos os caracteres, exceto para APM, que foi não-significativa. A outra interação ( $\mathrm{P} \times \mathrm{A} / \mathrm{ESALQ}$ ) não diferiu as progênies para os caracteres APM, CHS e PG; mas pôde diferí-las para NDM e Ac a $1 \%$, e VA a $5 \%$. Por outro lado, esta mesma interação para Anhembi não conseguiu distinguir as progênies para APM, Ac e VA; e apresentou diferenças a $1 \%$ para NDM e CHS, e a $5 \%$ para PG. A interação tripla $\mathrm{P} \times \mathrm{L} \times \mathrm{A}$ foi significativa somente para Ac (5\%), enquanto a tripla para testemunhas $(\mathrm{T} \times \mathrm{L} \times \mathrm{A})$ foi significativa para Ac e VA, também a $5 \%$.

Para o CMI (Tabela 24), efeitos significativos para todos os caracteres avaliados ao nivel de $1 \%$ pelo teste $\mathrm{F}$ foram detectados nas fontes de variação de ambientes, anos $\mathrm{e}$ 
Locais 97. Para os locais avaliados dentro do ano 96 (Locais 96) encontrou-se significâncias a $1 \%$ para os caracteres NDM e CHS, a 5\% para APM, e ausência de significância para Ac, VA e PG. No local ESALQ (3 anos), detectou-se diferenças a 1\% para todos os caracteres; no entanto o local Anhembi ( 2 anos) diferenciou somente para os caracteres APM, Ac e VA a 1\%, e para NDM a 5\%. As progênies comportaram-se de formas diferenciadas para todos os caracteres a $1 \%$, exceto para PG que foi a $5 \%$; enquanto as testemunhas não se diferenciaram para NDM, APM e Ac, sendo significativas a $1 \%$ para VA, CHS e PG. A interação de $\mathrm{P} \times \mathrm{L} / 96$ foi não-significativa apenas para VA e PG, sendo significativa a $1 \%$ para os demais caracteres; por outro lado, para o ano de 1997/98, esta mesma interação diferenciou APM a 5\% e todos os demais caracteres ao nivel de $1 \%$. A outra interação relativa aos anos ( $\mathrm{P} \times \mathrm{A})$ para ESALQ apresentou-se significativa a $1 \%$ para todos os caracteres, ao passo que para $o$ local Anhembi a significância encontrada foi para NDM, Ac e VA (1\%); CHS (5\%) e nenhuma significância para $\mathrm{APM}$ e $\mathrm{PG}$. A interação tripla $\mathrm{P} \times \mathrm{L} \times \mathrm{A}$ não detectou diferenças apenas para PG, apresentando significâncias a $1 \%$ para NDM, Ac e CHS; e a $5 \%$ para APM e VA. A outra interação tripla ( $\mathrm{T} \times \mathrm{L} \times \mathrm{A})$ detectou diferenças somente para APM, sendo esta a $5 \%$.

Por último, o CMST (Tabela 25) apresentou significâncias a 1\% para todos os caracteres no efeito de ambientes. Quanto ao efeito de anos, o CMST diferiu dos demais CM, por não apresentar significância para CHS. Os locais avaliados dentro do ano de 96 distinguiram-se entre si para a maioria dos caracteres ao nível de $1 \%$ pelo teste $F$, sendo não-significativos apenas para VA e PG; para o ano de 97 os locais se diferenciaram para todos os caracteres, exceto PG. O local ESALQ, nos três anos, comportou-se de forma diferente para todos os caracteres a $1 \%$; o local Anhembi não apresentou diferenças significativas para APM e PG; foi significativo a 1\% para Ac, VA e CHS; e a $5 \%$ para NDM. As progênies apresentaram um comportamento diferencial ao nível de $1 \%$ para NDM, APM, Ac, VA e CHS; sendo uniformes para PG. Por sua vez, as testemunhas tiveram comportamentos diferentes apenas para Ac (1\%) e NDM (5\%). A interação P x L, tanto para o ano 1996/97 quanto para 1997/98 não detectou diferenças para nenhum caráter. A interação com anos ( $\mathrm{P} \times \mathrm{A}$ ) para o local ESALQ, mostrou-se 
significativa apenas para VA a 1\% e NDM a 5\%; no entanto, a mesma interação para o local Anhembi, foi significativa a 1\% para APM e VA e a 5\% para NDM. A interação tripla $\mathrm{P} \times \mathrm{L} \times \mathrm{A}$ foi não-significativa para todos os caracteres, assim como a interação $\mathrm{T}$ $x$ L x A.

Analisando-se os resultados obtidos, na análise conjunta entre anos, observa-se que os experimentos ou ambientes foram variáveis para todos os caracteres avaliados e em todos os $\mathrm{CM}$, indicando que os fatores ambientais provavelmente não se repetiram em um mesmo local e de um ano para o outro. Isto é confirmado quando se observa a variação ocorrida entre os anos, pois os caracteres diferiram em praticamente todos os $\mathrm{CM}$, o que é confirmado pela alta significância dos caracteres nesta fonte de variação.

As interações $\mathrm{G} \times \mathrm{E}$ apresentaram-se significativas para todos os $\mathrm{CM}$, sendo a $1 \%$ para o CMSP e CMI, e a 5\% para o CMP e CMST. Sabe-se que a significância da interação $\mathrm{G} \times \mathrm{E}$ constitui-se em uma premissa para a utilização de métodos que avaliam a estabilidade fenotípica (Eberhart \& Russel, 1966; Silva \& Barreto, 1985; Wricke, 1965). Dessa forma, os resultados obtidos justificam a obtenção de estimativas de parâmetros de estabilidade das progênies avaliadas, visando-se identificar os genótipos com maior ou menor interação, tal como ocorreu com Yokomizo (1999). Nas tabelas de análise conjunta (Tabela 22 a 25 ), pode-se verificar que a interação $\mathrm{G} \times \mathrm{E}$ foi desdobrada em oito efeitos, dando ênfase ao ano avaliado e posteriormente, em outros oito efeitos enfocando os locais avaliados que se repetiram em mais de um ano. Os dois tipos de desdobramento são separados pelos pontilhados situados logo abaixo da fonte de variação G x E nas tabelas, e o somatório dos seus GL são equivalentes. Estes dois tipos de desdobramentos serão então discutidos para melhor compreensão destes efeitos.

Os locais avaliados dentro no ano $1997 / 98$ em todos os CM detectaram diferenças em um maior número de caracteres do que os locais avaliados em 1996/97, indicando que o ano de 1997/98 talvez tenha oscilado mais quanto aos fatores ambientais do que o ano anterior. Aliado a isto, nos desdobramentos da interação $\mathrm{G} \times \mathrm{E}$ já citados, observa-se também que a interação P x L para o ano de 1996/97 apresentou menor número de caracteres diferenciados do que a mesma interação para o ano de $1997 / 98$, sugerindo que os locais no segundo ano interagiram mais com o mesmo grupo 
de progênies avaliadas, do que no primeiro ano. Tal fato ocorreu tanto no CMSP como no $\mathrm{CMI}$, sendo que no CMP o número de caracteres diferenciados foi igual entre os locais, tanto para o ano 96 quanto para o ano 97; já no CMST, nenhum caráter apresentou variabilidade para os locais em ambos os anos.

Ainda com relação aos locais utilizados para instalação dos experimentos, notouse que no local ESALQ, no decorrer dos anos avaliados, detectou-se uma maior variabilidade genética entre as progênies avaliadas, através da significância da interação P x A, do que no local Anhembi, através da mesma interação. Isto pode ser observado nas análises conjuntas do CMP e CMI, onde as progênies foram variáveis para um maior número de caracteres na ESALQ do que no Anhembi, nos anos avaliados, quando se compara as interações para os dois locais. No CMSP, o número de caracteres significativos foi igual em ambos os locais. Porém, no CMST, ocorreu o inverso, de forma que três caracteres apresentaram variabilidade nas progênies avaliadas no Anhembi, enquanto que na ESALQ, apenas dois dos seis caracteres avaliados diferiram.

As significâncias dos efeitos de progênies presentes na maioria dos caracteres das PPR, PSP e PST, e em todos os caracteres avaliados nas PIN, confirmam a variabilidade presente entre as progênies dos quatro $\mathrm{CM}$, detectada também nas análises individuais e conjunta por ano, realizadas anteriormente. Este fato também foi observado por Rocha (1998) para os mesmos seis caracteres e quatro CM avaliados. As testemunhas, concordando com as análises anteriores, apresentaram menor variabilidade genética do que as progênies oriundas de cruzamentos óctuplos; as diferenças de variabilidade entre progênies e testemunhas podem ser explicadas, pelo menos parcialmente, pelo número de parentais ( 8 vs 2 ) envolvidos nos cruzamentos. A alta variabilidade obtida nestas gerações avaliadas coincidem com os resultados obtidos por Lopes (1996) na geração $F_{1[8]}$ destas mesmas populações.

Com relação ao contraste $P$ vs $T$, o qual detecta diferenças presentes entre os grupos de genótipos, o ciclo que mais diferenciou foi o $\mathrm{CMI}$, obtendo diferenças entre progênies e testemunhas para os caracteres NDM, APM, Ac, VA e CHS; no CMSP, progênies e testemunhas diferiram para NDM, APM, VA e CHS; enquanto que no 
CMST detectou-se diferenças para NDM, Ac, VA e PG. O CMP foi o que menos diferiu quanto aos grupos de genótipos, apresentando significância somente para Ac e VA.

A interação tripla, que mede o comportamento dos genótipos nos vários locais e anos avaliados, diferenciou mais progênies do que as testemunhas para um maior número de caracteres, no CMP e no CMI. No CMSP, o grupo das testemunhas foi diferenciado para dois caracteres enquanto o grupo das progênies apenas para um. Por fim, no CMST nenhum dos dois grupos de genótipos obteve variabilidade para quaisquer caracteres avaliados nos vários locais $\mathrm{e}$ anos, quando analisados conjuntamente.

Os CV's obtidos nas análises conjuntas entre os anos, comportaram-se como todas as análises de variância anteriores, ou seja, com valores menores para NDM (1,52 a $1,91 \%)$ e VA (5,31 a 6,71\%); valores de magnitudes intermediárias para APM $(9,91$ a $12,71 \%)$, Ac $(9,24$ a $13,04 \%)$ e CHS (10,30 a $15,26 \%)$; e valores mais altos para PG $(18,58$ a $22,02 \%)$. Tais magnitudes são aceitáveis e concordam com os resultados obtidos nas análises anteriores (individuais e por ano) e de outros trabalhos realizados (Soldini, 1993; Farias Neto, 1995; Laínez-Mejía, 1996; Rocha, 1998 e Yokomizo, 1999). Os CM com menores valores de CV's foram: CMST para NDM e APM; CMI para VA e CMP para Ac, CHS e PG. Os CM com as maiores médias para os caracteres foram concordantes com os menores CV's obtidos para NDM, APM e VA, assim como nas análises por ano. Para o caráter Ac, esta concordância não era mesmo esperada, já que uma maior nota de acamamento, significa um comportamento indesejável para o experimento, pelo fato de prejudicar inclusive a produtividade de grãos e, portanto, tendendo a um maior CV. Para CHS, a situação é similar, pois uma maior média do caráter, está associado a uma maior incidência da doença, que pode influenciar negativamente outros caracteres, entre eles PG. Para PG, o CM de maior média foi o CMI, mas nota-se que o seu CV $(18,76 \%)$ está muito próximo do menor CV obtido $(18,58 \%)$; portanto a relação citada entre o menor CV e a maior média, de acordo com Arias (1996), continua sendo válida. Ainda em relação a PG, este pode ter sofrido influências fortes da incidência da doença CHS no CMI, que apresentou a segunda maior média neste ciclo $(1,37)$, perdendo apenas para o CMST $(1,42)$, o qual permanece 
mais tempo no campo, tornando-se mais vulnerável à incidência do fungo. O CMP, através do mecanismo de escape, torna-se pouco suscetivel à doença, mesmo que não possua genótipos resistentes, pois sua colheita geralmente ocorre antes do período crítico de ocorrência da doença. Esta situação pode ser muito bem visualisada nas médias para CHS nas análises conjuntas do CMP, CMSP, CMI e CMST (Tabelas 22 a 25) respectivamente, onde a média dos valores das notas transformadas, que reflete a incidência da doença, aumenta gradativamente com o aumento do ciclo, indo de 1,29 (CMP) a 1,42 (CMST). Rocha (1998) também obteve resultados semelhantes para reação ao CHS ao avaliar linhagens experimentais de soja com diferentes CM.

As maiores médias para os caracteres NDM, APM e Ac foram observadas no CMST, justificadas pelo aumento do ciclo dos genótipos pertencentes a este CM, que é medido pelo NDM. O caráter APM é decorrente também do aumento do NDM, devido ao maior período disponível para crescimento da planta, e o Ac tende a ser maior com o aumento do APM. A maior média para VA foi obtida nos CMSP e CMI, que são os ciclos que tendem a ter um maior número de caracteres favoráveis agrupados. Nos resultados obtidos para o caráter PG, observou-se maior média no $\mathrm{CMI}$, seguido pelo CMST. Todos os resultados citados acompanharam a tendência obtida nas análises conjuntas por ano, para todos os caracteres, inclusive para CHS, que já havia sido citado no parágrafo anterior. Os resultados relativos à $\mathrm{PG}$ concordam parcialmente com os obtidos por Rocha (1998), que detectou o CMI como mais produtivo, porém encontrou o CMST como o menos produtivo em suas observações. Por outro lado, Soldini (1993) e Laínez-Mejía (1996) encontraram as maiores médias de PG no CMST, e comentam que quanto menor a sobreposição das fases vegetativas e reprodutivas presentes no ciclo da planta, melhor será o aproveitamento dos assimilados para os órgãos reprodutivos da planta, ou seja, flores e grãos.

\subsection{Avaliação da estabilidade fenotípica}

As medidas de estabilidade fenotípica foram obtidas através das estimativas de interação $G \times E$ obtidas pelo método da ecovalência proposto por Wricke (1965). De 
acordo com Rognli (1987), as classificações feitas por este método podem sofrer alterações de um ano de avaliação para outro, então Wricke (1965) recomenda que as avaliações sejam feitas utilizando-se resultados obtidos em três ou quatro anos, para uma maior precisão dos resultados.

O objetivo desta análise foi verificar a estabilidade dos genótipos, dentro de cada CM. Desta forma, as análises foram realizadas para cada CM, e para cada caráter individualmente. Nas Tabelas $26,27,28$ e 29 , observa-se os valores de ecovalências (eco) encontrados para os CMP, CMSP, CMI e CMST, respectivamente. Os valores indicados por eco\% representam a porcentagem da ecovalência no total da interação genótipo $\mathrm{x}$ ambiente. Como as tabelas se referem aos genótipos individualmente, as eco\% representam a contribuição de cada genótipo para a interação genótipo $\mathrm{x}$ ambiente total, para cada caráter. As progênies pertencentes a cada CM são comuns a todos os ambientes avaliados, enquanto que as testemunhas são os cultivares utilizados como padrões nos experimentos, específicos para cada $\mathrm{CM}$ e também comuns a todos os ambientes avaliados; houve participação de duas testemunhas para o CMP e CMSP e três para o CMI e CMST. Para maior facilidade das discussões, as progênies serão tratadas por números, e seus respectivos números USP encontram-se nas Tabelas 26, 27, 28 e 29; juntamente com os valores de ecovalências. Menores valores de ecovalência estão associados com maior estabilidade fenotípica e vice-versa.

Conforme mencionado anteriormente, existem poucos trabalhos na literatura que já utilizaram este método, sendo que com a cultura da soja foram encontrados os trabalhos de Yue et al. (1997) e o de Yokomizo (1999). Outros trabalhos foram citados porém, utilizando-se este método em outras culturas como a cana-de-açúcar (Kang \& Miller, 1984; Raizer, 1998) e o feijoeiro (Duarte \& Zimmermann, 1995).

\subsubsection{Grupo Precoce}

Para este $\mathrm{CM}$, assim como na análise conjunta, 17 progênies foram submetidas ao teste de estabilidade fenotípica de Wricke (1965), as quais eram comuns aos seis ambientes avaliados. 
Analisando-se as estimativas de ecovalências (eco) obtidas para o CMP (Tabela 26), observa-se que para o caráter NDM, as PPR com menores estimativas de eco, ou seja, com maior estabilidade fenotípica foram as PPR 1,5 e 7 , tendo suas ecovalências de 147,89 a 163,71 ; estas foram muito menores que as obtidas pelas testemunhas $(497,57$ e 793,61$)$. Enquanto as testemunhas contribuíram com aproximadamente 3 a $5 \%$ para a interação, as PPR mais estáveis contribuíram com apenas 0,9 a $1 \%$ em média. As PPR menos estáveis, ou seja, aquelas que mais contribuiram para a interação genótipo $x$ ambiente foram as PPR 2, 10 e 14 que contribuíram com 22,5, 10,3 e 10,1\% respectivamente, perfazendo $42,9 \%$ do total da interação e superando em magnitude as testemunhas.

Para o caráter APM, as menores estimativas foram obtidas para as PPR 3, 11, 13 e 17; possuindo valores de eco variando de 2475,44 a 3240,03 ; sendo suas contribuições desde 2,4 a $3,1 \%$; porém, foram ainda bem maiores que as testemunhas, que contribuíram com apenas 0,8 e 1,3\% para a interação. Os genótipos com menores estabilidade foram as PPR 1, 2 e 12 contribuindo com 9 a $15 \%$ cada uma delas, para o efeito total da interação. Para este caráter, como foi observado, nenhuma progênie foi detectada apresentando estabilidade fenotípica superior às testemunhas utilizadas, porém as contribuições foram mais distribuídas entre os genótipos (progênies e testemunhas ) que para o caráter NDM, que apresentou genótipos mais discrepantes para maior e menor estabilidade.

Com relação ao Ac, as menores contribuições de ecovalência no grupo das PPR foram detectadas para aquelas de número $1,2,9$ e 13 com contribuições entre 0,8 e $2,8 \%$. As testemunhas também contribuíram pouco $(0,8$ a $1,1 \%)$, podendo-se observar que somente uma progênie foi similar ao comportamento de uma das testemunhas. As PPR menos estáveis foram as de número 5, 10 e 17, tendo suas eco\% variando de 9 a $12,6 \%$, comprovando uma maior magnitude de contribuição para a interação genótipo $\mathrm{x}$ ambiente, quando comparadas às testemunhas. Como no caráter APM, as contribuições foram mais uniformemente distribuídas entre os genótipos.

Para o caráter VA, menores valores de ecovalência e, consequentemente das suas contribuições à interação (eco\%), foram observadas nas PPR 5,6 e 9, tendo as duas 
primeiras contribuido com $2,1 \%$ e a última com 2,2\%. Estas PPR foram mais estáveis que as testemunhas Primavera $(2,8 \%)$ e IAS-5(2,3\%). Todas as demais PPR apresentaram valores superiores de eco\%, ou seja, possuem comportamento mais instável que as testemunhas utilizadas. As que apresentaram maiores valores foram as PPR 3, 8 e 13; com percentuais de contribuição variando de 7,8 a 10,9\%. Para este caráter, uma alta uniformidade das contribuições também foi observada, talvez devido ao fato de ser um caráter altamente subjetivo nas avaliações.

Para a reação ao cancro-da-haste da soja (CHS), os valores obtidos quanto às contribuições dos genótipos foram extremamente desuniformes, sendo que apenas três PPR, de número $6(24,9 \%), 7(12,3 \%)$ e $17(19,5 \%)$ totalizaram $56,7 \%$ do efeito da interação genótipo $x$ ambiente. As PPR 2, 10 e 15 foram as de menor ecovalência estimada, contribuindo apenas com 0,3 a $0,9 \%$ do total. As PPR 2 e 10 tiveram suas ecovalências equivalentes à testemunha Primavera $(0,3 \%)$, sendo que a testemunha IAS5 teve sua estabilidade fenotípica superada pelas três progênies citadas e igualado por outras seis progênies $(1,4,11,12,14$ e 16$)$.

O caráter PG, juntamente com VA, foram os que tiveram suas contribuições mais uniformemente distribuídas. Para PG, apenas a progênie 3 superou $10 \%$ de contribuição, com eco $\%$ de $11,9 \%$ sendo, portanto, a menos estável. Os outros genótipos que apresentaram baixa estabilidade foram as PPR 2, 12 e 17 (8,3 , 9,5 e 9,8\%). As PPR com maior estabilidade foram a $4(2,7 \%), 7(0,9 \%), 10(2,7 \%)$ e $14(2,6 \%)$, sendo todas mais estáveis que a testemunha IAS-5 (2,84\%). Por outro lado, a testemunha Primavera, com eco $\%$ de $2,2 \%$, foi superada em estabilidade apenas pela PPR $7(0,92 \%)$.

Os resultados obtidos pelo Teste de Wricke, com o cálculo das ecovalências para os genótipos avaliados (PPR e testemunhas) relativo aos seis caracteres (NDM, APM, Ac, VA, CHS e PG) podem ser claramente visualizados através dos gráficos de barra presentes na Figura 3.

Os valores de ecovalência obtidos também foram submetidos ao teste de significância para verificar quais as contribuições para a interação genótipo $\mathrm{x}$ ambiente seriam ou não significativas. A ausência de significância da ecovalência através deste teste comprova não só a sua baixa magnitude mas também a estabilidade fenotípica do 
genótipo avaliado para aquele caráter. A grande maioria das ecovalências dos genótipos manifestou significância, indicando que os genótipos interagiram com o meio ambiente, como já foi determinado nas análises por ano e conjunta; portanto, serão indicados nas tabelas somente os não-significativos (ou estáveis). Apenas nos caracteres APM, CHS e PG detectou-se genótipos com ausência de significância para a ecovalência conforme se observa na Tabela 26, sendo que para CHS, ocorreu o inverso de NDM, Ac e VA, com ausência de significância para todos os genótipos.

Analisando-se todos os caracteres, nota-se que não ocorreram grandes coincidências para destaques de estabilidade positivos ou negativos entre os mesmos, ocorrendo grandes variações de progênies e testemunhas destacados de um caráter para o outro. Porém, entre os caracteres NDM e APM, observa-se que a PPR 2 foi a de menor estabilidade para NDM e a segunda menos estável para APM. Para NDM e Ac, a PPR 10 apresentou a segunda menor estabilidade dentro do grupo. Quanto aos destaques positivos, entre os caracteres APM e Ac, a PPR 13 apresentou a segunda maior estabilidade dentre as progenies avaliadas. E entre CHS e PG, a PPR 10 foi uma das mais estáveis para CHS e a terceira mais estável para PG. Estes dados são concordantes com as observações de Yokomizo (1999), onde também não foi detectada coincidência para a maioria dos caracteres avaliados.

Nas Tabelas 30 e 31 são apresentados os valores de ecovalência médios $(\mathrm{Meco} \%)$ e os desvios padrões das ecovalências (Seco\%) das progênies, referentes às ecovalências obtidas em todos os caracteres para cada progênie individualmente, dentro de cada CM. Através destes parâmetros, pode-se detectar o limite máximo aceitável para a classificação de um genótipo como estável. Este limite máximo tomado será o maior valor de ecovalência média obtido nas testemunhas. Sendo assim, para o CMP (Tabela 30 ) tomando-se a testemunha Primavera $(2,18 \%)$ como referência, observa-se que nenhuma das progênies pode ser considerada como estável, pois todas elas apresentaram Meco\% superiores ao valor máximo 2,18\%. A progênie que mais se aproximou, foi a 4 $(3,81 \%)$, que apresentou também o menor desvio padrão $(1,89 \%)$ entre as progênies, e também com boa estabilidade para o caráter PG (Tabela 26). Tal fato pode ter ocorrido 
devido ao pequeno número de progênies avaliadas neste $\mathrm{CM}$, o que distribui de maneira desuniforme o efeito da interação genótipo $\mathrm{x}$ ambiente.

\subsubsection{Grupo Semi-Precoce}

Nas análises de estabilidade do CMSP, 30 progênies comuns a todos os ambientes avaliados nos três anos agrícolas, foram submetidas ao teste. Com relação à distribuição das contribuições relativas de cada genótipo para a interação genótipo $\mathrm{x}$ ambiente, de modo geral, neste $\mathrm{CM}$ a distribuição foi bem maior do que no CMP em todos os caracteres avaliados, principalmente pelo fato do número de tratamentos ter sido praticamente duplicado no CMSP, quando comparado ao CMP.

Para o caráter NDM, o genótipo com menor estabilidade foi a testemunha BR-16 que apresentou uma estimativa de contribuição através da ecovalência de $10 \%$ enquanto que a testemunha IAC-Foscarin-31 contribuiu com 4,2\%. Entre as PSP, as menos estáveis foram as progênies $8,13,21$ e 29 , que tiveram suas ecovalências variando de 5,3 a 7,3\%. Em contrapartida, as mais estáveis foram as PSP 10, 12, 17 e 27, com contribuições muito pequenas variando de 0,4 a $1 \%$ para a interação genótipo $x$ ambiente. Sendo assim, todas as PSP testadas apresentaram maior estabilidade para NDM que a testemunha BR-16, e do total de 30 progennies deste $C M, 25$ foram mais estáveis que IAC-Foscarin-31.

Com relação ao caráter APM, as progênies 6, 7,9 e 29 foram os genótipos que apresentaram menor estabilidade (eco\% entre 6,5 e 7,3\%), superando as testemunhas BR-16 e IAC-Foscarin-31, com eco\% de 1,6 e 3,9\%, respectivamente. As PSP 10, 18, 23 e 27 foram as mais estáveis, apresentando baixas contribuições para a interação genótipo $\mathrm{x}$ ambiente (entre 0,5 e $1 \%$ ). Outras PSP apresentaram-se com boa estabilidade fenotípica, sendo que nove foram mais estáveis que a testemunha BR-16 $(1,68 \%)$

Analisando os resultados obtidos para Ac, nota-se que as testemunhas apresentaram baixas estimativas de ecovalência $(2,0$ e 3,6\%), comprovando boa estabilidade fenotípica. Entre as PSP, as mais estáveis foram as de número 5, 7, 14 e 18; as quais apresentaram eco\% variando de 0,1 a $1 \%$ o que representa baixos valores de 
contribuição para a interação. Por outro lado, as PSP 4, 23, 24 e 30 foram as de menor estabilidade, com estimativas de 6,1 a $9,9 \%$, valores estes superiores ao maior valor de eco $\%$ das testemunhas (IAC-Foscarin-31 com 3,6\%).

De acordo com os valores obtidos de ecovalência para o caráter VA nas PSP, observa-se que as PSP 6, 13, 17 e 20 destacaram-se pelas suas baixas contribuições à interação genótipo $\mathrm{x}$ ambiente que foram de $1,0,0,6,0,9$ e $0,5 \%$, respectivamente. Por outro lado, as progênies $1,9,11$ e 19 apresentaram-se como as menos estáveis com eco\% variando de 4,6 a 7,9\%. No total, 28 PSP foram mais estáveis que a testemunha menos estável BR-16 (eco\% de 7,1\%) e 14 apresentaram estabilidade fenotípica maior que a testemunha mais estável IAC-Foscarin-31 para o caráter VA.

O caráter CHS foi o que apresentou distribuição mais desuniforme das ecovalências entre os genótipos estudados. Observou-se que as quatro PSP menos estáveis $(7,19,22$ e 24) apresentaram altos valores de eco\%, totalizando somente entre elas cerca de $34 \%$ do efeito da interação genótipo $\mathrm{x}$ ambiente, sendo que a menos estável (progênie 19) representou 13,4\%. As PSP 2, 14, 15, 18, 26 e 30 apresentaram comportamento semelhante, e os mais estáveis obtidos, com eco\% variando de 0,2 a $0,9 \%$, considerados muito baixos, e menores que as testemunhas BR-16 (3\%) e IACFoscarin-31 $(1,8 \%)$ que são considerados genótipos resistentes a esta doença. Entre todas as progênies, 12 mostraram-se iguais ou mais estáveis que a testemunha mais estável (IAC-Foscarin-31), e 18 apresentaram eco\% menor ou igual à testemunha BR16.

Para o caráter PG, as PSP 1, 5, 7 e 9 apresentaram as menores estabilidades e consequentemente as maiores ecovalências, totalizando uma contribuição de $35,8 \%$ para a interação genótipo $\mathrm{x}$ ambiente. Os genótipos com maiores estabilidades fenotípicas para o caráter PG foram as PSP 4, 16, 22 e 26 (eco\% de 0,8, 1, 0,9 e 1\%) totalizando entre as quatro progênies apenas $3,7 \%$ da contribuição para a interação. As testemunhas BR-16 e IAC-Foscarin-31 apresentaram eco $\%$ de 5,3 e 1,7\%, respectivamente; portanto pode-se concluir que 27 das 30 PSP foram mais estáveis que a testemunha BR-16, com eco\% menores que esta; e 11 apresentaram maior estabilidade que a testemunha IACFoscarin-31, na qual foi detectado um baixo valor de eco\%. 
As ecovalências obtidas para os genótipos (PSP e testemunhas) avaliados neste CM para os caracteres NDM, APM, Ac, VA, CHS e PG, encontram-se representadas na Figura 4.

O teste de significância para o CMP detectou que os caracteres APM, Ac, VA e CHS possuem genótipos que não interagiram de forma significativa com o ambiente, ou seja, apresentaram materiais seguramente estáveis para tais caracteres. Por outro lado, para NDM e PG todos os genótipos contribuíram de forma significativa para o efeito da interação genótipo $\mathrm{x}$ ambiente, conforme se observa na Tabela 27.

Com relação às progênies coincidentes para os vários caracteres, a exemplo do CMP, observou-se também que não ocorreram coincidências maiores entre as progênies destacadas quanto à estabilidade dos caracteres em questão. Para CHS e PG a progênie 26 apresentou boa estabilidade. Entre APM e Ac, a progênie 18 também apresentou boa estabilidade. Já para NDM e APM, a progênie coincidente foi a 27 que se comportou como a mais estável para APM e a segunda mais estável para NDM. Quanto à instabilidade, a progênie 7 apresentou altos valores de ecovalência para CHS e PG; a progênie 29 para NDM e APM; além de baixa estabilidade detectada na progênie 19 para VA e CHS e também da alta ecovalência da progênie 24 para Ac e CHS.

$\mathrm{Na}$ Tabela 30 são apresentados os valores médios de ecovalência $(\mathrm{Meco} \%)$ e desvios padrões (Seco\%) para o CMSP. Adotando-se como limite máximo 4,89\% referente à testemunha $\mathrm{BR}-16$, observou-se que apenas as progênies 7 e 19 superaram este limite e, portanto, são consideradas instáveis. Os maiores desvios padrões também foram observados nestas progênies, confirmando esta classificação. Merecem destaque as progênies $2,5,8,10,12,14,15,16,17,18,20,23,26$ e 27, que apresentaram Meco\% menores que o valor obtido na testemunha mais estável IAC-Foscarin-31 (3\%); dentre estas se destacaram as progênies 2, 12, 16, 17 e 18 que além de apresentarem Meco\% menores, apresentaram também menores desvios padrões (Seco\%) que o da testemunha IAC-Foscarin-31 (1,09\%), reforçando ainda mais a classificação quanto à estabilidade. Esta metodologia de utilização de Meco\% e Seco\% também foi utilizada por Yokomizo (1999) e segundo este autor, o fato de existir neste CM, valores baixos de Meco\% e mais altos de Seco\%, indica que alguns caracteres podem apresentar maior interação genótipo 
$\mathrm{x}$ ambiente em relação a outros, podendo aumentar o desvio para aqueles que possuem ecovalências altas nestes caracteres. Nestes casos, recomenda-se que cada caráter seja considerado individualmente na análise de estabilidade fenotípica.

\subsubsection{Grupo Intermediário}

Para este $\mathrm{CM}$, assim como na análise conjunta entre anos, apenas 60 progênies foram avaliadas, as quais eram comuns a todos os experimentos instalados (Tabela 28). No entanto, este número de progênies ainda é bem superior que o número de progênies citados nos CM anteriores, dessa forma, como o teste de Wricke estuda a contribuição relativa de cada genótipo para a interação genótipo $\mathrm{x}$ ambiente, pela ecovalência, essa contribuição ficou ainda mais uniformemente distribuida entre os genótipos testados do que no CMP e CMSP. Sendo assim, não foram observados genótipos com valores altamente discrepantes para baixa estabilidade fenotípica, como nos CM citados anteriormente; porém foram observados valores que indicam alta estabilidade.

Para o caráter NDM, as PIN 11, 32, 38, 41, 45 e 58 apresentaram as menores estabilidades fenotípicas com valores de eco\% entre 3,6 e 4,1\% de contribuição para a interação. Neste CM, três testemunhas participaram das análises (Bossier, IAC-100 e IAC-12), tendo os seus valores de ecovalência variado desde 2,4 a 3,0\%. As PIN 13, 21, $39,40,43$ e 59 foram as que apresentaram maiores estabilidades fenotípicas com pequenas ecovalências variando de 0,2 a $0,4 \%$. No total das progênies avaliadas neste $\mathrm{CM}, 50$ apresentaram-se mais estáveis que a testemunha Bossier $(2,4 \%)$, que foi a mais estável das testemunhas para o caráter NDM.

Com relação ao porte (APM), os genótipos que apresentaram menor consistência para este caráter foram os de número $1,10,20,37,47$ e 58, com ecovalências encontradas variando de 2,9 a 7,4\%. Em contrapartida, as progênies $2,4,13,32,50$ e 54 exibiram uma alta estabilidade fenotípica, com baixos valores de ecovalência, variando de apenas 0,1 a $0,2 \%$; sendo todas estas mais estáveis que a testemunha com menor ecovalência (Bossier, 0,3\%) e também mais estáveis que as testemunhas IAC-100 e IAC-12, respectivamente com ecovalências de 0,5 e $0,7 \%$. No total, oito progênies 
demonstraram maior estabilidade fenotípica que a testemunha mais estável Bossier, representando 13,3\%; este percentual de genótipos pode ser considerado bastante favorável, quando se observa que a ecovalência de Bossier, foi muito pequena $(0,3 \%)$.

As avaliações para acamamento (Ac) revelaram que as PIN com menores estabilidades foram as de número $2,13,18,25,27$ e 57, com ecovalências variando desde 3,3 até $5,5 \%$, valores estes bem superiores às ecovalências das testemunhas Bossier $(0,5 \%)$, IAC-100 (1,3\%) e IAC-12 $(0,4 \%)$. Os genótipos mais estáveis para Ac no grupo das progênies foram os de número $19,22,24,43,50$ e 56 , todos apresentando ecovalências de 0,1 a $0,5 \%$; dessa forma, todos estes genótipos foram mais estáveis que as testemunhas Bossier e IAC-100. Deste grupo, apenas a progênie 19 foi menos estável que a testemunha IAC-12; todas as outras superaram este genótipo quanto à estabilidade.

Para o caráter VA, as PIN de número 25, 27, 30, 41, 45 e 57 foram as de maior instabilidade, tendo contribuído em uma boa parte para a interação genótipo $\mathrm{x}$ ambiente, com valores de ecovalência desde 2,9 a 5,9\%; o que totaliza um efeito de $22,9 \%$ para a interação, sendo considerado alto para apenas seis progênies, ou seja, 10\% das progênies totais. As progênies $5,22,48,49,50$ e 55 totalizaram apenas $1,87 \%$ do efeito da interação, sendo portanto as mais estáveis do CMI para o caráter VA, pois suas ecovalências foram extremamente pequenas e variaram somente de 0,2 a $0,4 \%$. As testemunhas foram variáveis apresentando valores de eco\% de $0,8 \%$ (Bossier), 2,2\% (IAC-100) e 3,6\% (IAC-12). No geral, 11 progênies apresentaram ecovalências menores ou iguais a aquela apresentada pela testemunha Bossier, a mais estável das três testemunhas.

Analisando-se os dados obtidos para a reação ao CHS, observou-se que as testemunhas foram mais estáveis e pouco variáveis para este caráter, apresentando ecovalências de 0,3 a $0,8 \%$, sendo novamente a testemunha Bossier, a de maior estabilidade fenotípica. As progênies, por sua vez, foram muito discrepantes, apresentando contribuições que variaram desde $0,1 \%$ (progênie 31 ) a $6,5 \%$ (progênie 54). As mais instáveis foram as de número $25,27,34,36,54$ e 59 , com ecovalências de 3,9 a $6,5 \%$, as quais juntas totalizaram uma contribuição de $28,3 \%$. As mais estáveis foram as progênies $19,31,44,45,49$ e 55 ; que por sua vez juntas contribuíram com 
apenas $1,25 \%$ para a interação e se apresentaram mais estáveis que a testemunha Bossier, que apresentou um valor muito baixo de ecovalência para CHS.

Para a produtividade de grãos (PG), caráter de extrema importància para o melhoramento, as progênies também se apresentaram altamente variáveis, apresentando valores de ecovalência mínimos $(0,02 \%)$ como a progênie 42 , até valores tido como altos $(6,7 \%)$, como o da progênie 26 . As progênies de maior estabilidade fenotípica para este caráter foram as de número $7,13,15,38,42$ e 50 , as quais juntas contribuíram com apenas $1,73 \%$ do total da interação genótipo $\mathrm{x}$ ambiente, pois tiveram valores de ecovalência pequenos, variando entre 0,02 a $0,4 \%$. Entretanto, as maiores contribuições vieram das progênies $23,26,27,33,41$ e 58 , que totalizaram $27,3 \%$ do efeito da interação. As testemunhas apresentaram ecovalências baixas, indo de 0,6 a $1,5 \%$, tendo IAC-100 se apresentado como a mais estável dentre as três, para o caráter PG, sendo que no total, 11 progênies, ou seja, $18,3 \%$ das progênies, foram mais estáveis que IAC-100.

As ecovalências obtidas para os genótipos (PIN e testemunhas) avaliados para os caracteres NDM, APM e Ac, encontram-se representadas na Figura 5; e para os caracteres VA, CHS e PG na Figura 6.

De acordo com a Tabela 28 , o teste de significância para os genótipos do CMI detectou genótipos estáveis, ou seja, com contribuições não-significativas para a interação genótipo x ambiente para os caracteres APM, Ac, CHS e PG; já para os caracteres NDM e VA, todos os genótipos apresentaram contribuições significativas

Quanto às classificações coincidentes para alta ou baixa estabilidade, estas ocorreram em menor número, assim como nos CMP e CMSP. Porém, algumas podem ser observadas, como a progênie 13 que apresentou boa estabilidade para NDM, APM e PG; a progênie 19 com boa estabilidade para Ac e CHS; e a progênie 22 exibiu baixas ecovalências para Ac e VA; além de boa estabilidade detectada na progênie 50 para APM, Ac, VA e PG. Entre VA e CHS, destacaram-se as progênies 49 e 55. Para baixa estabilidade, destacou-se a progênie 25 para os caracteres Ac, VA e CHS; a progênie 27 foi instável para Ac, VA, CHS e PG; a progênie 41 apresentou altos valores de ecovalência para os caracteres NDM, VA e PG; por outro lado, instabilidade ocorreu na 
progênie 45 para NDM e VA; na progênie 57 para Ac e VA e na progênie 58 para NDM e APM.

Com relação aos valores gerais de ecovalência, incluindo todos os caracteres, na Tabela 31 encontram-se os valores médios de ecovalência (Meco\%) e desvios padrões (Seco\%) para o CMI. Tomando-se como limite máximo, o da testemunha IAC-12 $(\mathrm{Meco} \%=1,72 \%$ e Seco\%=1,34\%), observa-se que dentre as 60 progênies deste CM, 39 destas, ou seja, $65 \%$ podem ser consideradas estáveis, pois possuem Meco\% abaixo do limite de $1,72 \%$ e 37 progênies possuem além disso, um menor desvio padrão do que o observado na testemunha IAC-12. Uma seleção mais intensa pode ser feita tomando-se como referência a testemunha mais estável Bossier (Meco\% $\%=0,91)$; neste caso, existiram quatro progênies com menores valores quando comparadas a esta testemunha, tanto para $\mathrm{Meco} \%$ quanto para Seco\%. Estas comparações confirmam os bons resultados obtidos quanto à estabilidade fenotípica para as progênies pertencentes ao CMI.

\subsubsection{Grupo Semi-Tardio}

Neste CM, 20 progênies foram submetidas ao teste de Wricke (1965), de modo a se avaliar a estabilidade fenotípica de tais genótipos. Estas progênies eram comuns a todos os seis experimentos instalados, assim como as três testemunhas utilizadas (IAC11, IAC-4 e IAC-8). A análise foi realizada para os mesmos caracteres avaliados nos outros $\mathrm{CM}$ e os resultados encontram-se na Tabela 29. A tendência para este CM é apresentar uma maior distância entre os menores e maiores valores de ecovalência, devido ao pequeno número de progênies testadas.

$\mathrm{Na}$ Tabela 29, para o caráter NDM, observa-se que os genótipos mais instáveis no grupo das progênies são as de número $3,4,9 \mathrm{e} 11$, as quais apresentaram ecovalências de 5,2 a 9,7\%; perfazendo $27,3 \%$ do total da contribuição para a interação genótipo x ambiente. As progênies 6, 13, 14 e 19 apresentaram as menores ecovalências e, dessa forma, a maior estabilidade fenotípica (eco\% entre 0,3 e 1,4\%), sendo responsáveis por apenas $4,23 \%$ do efeito da interação. As testemunhas apresentaram-se altamente instáveis para NDM, de modo que suas ecovalências variaram entre 7,0 (IAC- 
11) e $11,5 \%$ (IAC-4). Portanto, o genótipo de maior instabilidade para NDM foi a testemunha IAC-4, na qual se obteve um valor de ecovalência considerado muito alto. Todas as progênies foram mais estáveis que IAC-4, e 19 do total foram mais estáveis que IAC-8 e IAC-11.

Para o caráter APM, valores altos de ecovalência foram obtidos nas progênies 5 , $9,10,11$ e 12 , com variações de 9,1 a $11,3 \%$ de eco\%, concentrando nestas cinco progênies ( $25 \%$ do total neste CM) uma contribuição de $49,2 \%$ do efeito da interação genótipo $\mathrm{x}$ ambiente. Por sua vez, as progênies com menores ecovalências para APM foram as de número $1,6,13$ e 15 ; tendo suas ecovalências entre 0,5 e 1,1\%, representando uma pequena contribuição para o total. As testemunhas variaram entre $0,9 \%$ (IAC-11) e $4,9 \%$ (IAC-4) de ecovalência. Pelo fato da testemunha IAC-11 ter se comportado com boa estabilidade fenotípica para este caráter, e as progênies terem apresentado altos valores de ecovalência, apenas a progênie 6 teve maior estabilidade que esta testemunha.

Com relação ao comportamento do CMST para o acamamento (Ac), as PST 3, 7, 8 e 9 foram as de menor estabilidade, com ecovalências estimadas entre 7,1 e 14,8\%; destacando-se a progênie 3 que apresentou ecovalência de $14,8 \%$, sendo a maior entre todos os caracteres avaliados neste CM. Estes altos valores perfazem uma contribuição de $38,6 \%$ para a interação, englobando apenas as quatro progênies citadas. As progênies mais estáveis foram as de número $10,12,14$ e 19, com ecovalências entre 0,2 e 1,8\%. As testemunhas foram muito discrepantes, com valores estimados de $0,5 \%$ (IAC-4), $5,2 \%$ (IAC-8) e 7,5\% (IAC-11). A testemunha IAC-11 que foi a mais estável para NDM e APM, comportou-se como a de menor estabilidade para Ac, e, portanto, com a maior ecovalência obtida no grupo; deixando a maior estabilidade para Ac por conta da testemunha IAC-4. Esta alta estabilidade de IAC-4 (eco\% de 0,5\%) foi superada apenas pela progênie 12 (eco\% de $0,2 \%)$.

O caráter VA, no geral, apresentou melhor distribuição entre as PST, do que os demais caracteres, obtendo o menor valor para a ecovalência de $0,3 \%$ (progênie 12 ) e o maior de $9,3 \%$ (progênie 15 ), enquanto um grande número de progênies com valores intermediários de ecovalência foi observado neste CM para este caráter. Entre as 
progênies mais instáveis, as que se destacaram foram as de número $1,5,15$ e $20 \mathrm{com}$ contribuições para a interação $\mathrm{G} \times \mathrm{E}$ variando de 7,1 a 9,3\%. As progênies $2,12,13$ e 18 foram as mais estáveis, com pequenos valores de ecovalência (entre 0,3 e 1,7\%). As testemunhas apresentaram baixas contribuições para a interação, fornecendo ecovalências de 1,1\% (IAC-4) a 3,3\% (IAC-11). Como no caráter Ac, a testemunha IAC-4 foi a mais estável, e se para aquele ela foi superada por uma progênie, para este caráter, duas progênies apresentaram-se mais estáveis do que ela (progênies 12 e 13).

Nas estimativas de ecovalências obtidas a partir das notas de CHS, observou-se uma alta discrepância entre as progênies, com estimativas de $0,2 \%$ (progênie 1) até 13,2\% (progênie 10). Em torno das progênies 3, 10, 11 e 13, que representam $20 \%$ do total, concentrou-se $40,5 \%$ do efeito da interação $\mathrm{G} \times \mathrm{E}$, sendo classificadas como as mais instáveis deste $\mathrm{CM}$. As mais estáveis, representando $25 \%$ de todas as progênies, foram as de número $1,4,12,14$ e 19 , as quais contribuíram com apenas $4 \%$ do total da interação. As testemunhas IAC-11 e IAC-8 apresentaram as mesmas estimativas de ecovalências $(3,9 \%)$, enquanto o valor estimado de IAC-4 foi de $4,1 \%$. Um total de 12 progênies foram mais estáveis para CHS que as testemunhas IAC-11 e IAC-8, o que é considerado um bom resultado de comportamento das progênies deste ciclo, já que estes cultivares são considerados de boa resistência ao CHS; deve-se lembrar que as PST são as mais suscetiveis à ocorrência desta doença, conforme comentado anteriormente.

Para o caráter PG, as PST que demonstraram maior estabilidade fenotípica foram as de número 2,10,12 e 14, pois apresentaram valores baixos de ecovalência (desde 0,6 a $1,6 \%$ ), representando apenas $4,3 \%$ do total da interação $G \times E$. No entanto, as progênies mais instáveis contribuíram com $34,9 \%$ para a interação, sendo estas representadas pelos números 1, 3,5 e 11. As testemunhas apresentaram comportamento um pouco variável: IAC-11 com $6,4 \%$ de ecovalência, IAC-4 com $2,8 \%$ e IAC-8 com $2,6 \%$. Observa-se que a testemunha mais estável para PG foi IAC-8, tendo sua estabilidade fenotípica superada por oito das $20 \mathrm{PST}$, ou seja, $40 \%$ das progênies avaliadas foram mais estáveis para PG do que a testemunha que apresentou maior estabilidade. Este é um resultado muito satisfatório, pois apesar das progênies obtidas por cruzamentos óctuplos terem apresentado uma ampla variabilidade genética nas 
análises de variância, uma boa parte delas conseguiu preservar sua estabilidade fenotípica, concordando com Allard (1971) e Allard \& Bradshaw (1964), onde relatam que genótipos com maior variabilidade tendem a ser mais estáveis

Os resultados obtidos para $\mathrm{PG}$ em todos os $\mathrm{CM}$ relativos à amplitude das ecovalências foram maiores do que as encontradas por Yue et al. (1997); porém estiveram mais próximas daquelas obtidas por Yokomizo (1999).

A representação gráfica das ecovalências obtidas para os genótipos (PST e testemunhas) avaliados para NDM, APM, Ac, VA, CHS e PG, pode ser visualizada na Figura 7.

Através do teste de significância da ecovalência, observou-se que todos os caracteres apresentaram algum genótipo estável no CMST, ou seja, pelo menos um genótipo não contribuiu de forma significativa para a interação genótipo $\mathrm{x}$ ambiente, em todos os caracteres avaliados. Os caracteres com maior número de genótipos nãosignificativos foram Ac, CHS e PG, conforme apresentado na Tabela 29.

Valores altos e baixos de ecovalência não foram consistentemente detectados para todos os caracteres, tal como ocorreu nos CMP, CMSP e CMI. Porém, alguns destaques podem ser observados para alta estabilidade: a progênie 1 foi coincidente para APM e CHS; a progênie 5 para NDM e APM; a progênie 10 para Ac e PG; a progênie 13 para NDM, APM e VA; a progênie 19 para NDM, Ac e CHS. Os maiores destaques foram para a progênie 12 , que se apresentou estável para quatro caracteres (Ac, VA, CHS e PG) e para a progênie 14, que foi estável também para quatro caracteres (NDM, Ac, CHS e PG). Quanto a altos valores de ecovalência, ou baixas estabilidades, destacaram-se a progênie 1 , que foi instável para VA e PG; a progênie 10 para APM e CHS; a progênie 9 para NDM, APM e Ac. As maiores instabilidades deste ciclo foram observadas na progênie 3 para os caracteres NDM, Ac, CHS e PG; e na progênie 11 para os caracteres NDM, APM, CHS e PG.

Analisando-se os valores médios de ecovalência (Meco\%) obtidos, e os de desvio padrão (Seco\%) para o CMST, apresentados na Tabela 31, adota-se como limite máximo aquele obtido pela testemunha IAC- 11 , ou seja, Meco\%=4,88 e Seco\%=2,56\%. Das 20 progênies testadas, 14 destas ou $70 \%$ do total, podem ser consideradas estáveis, pois 
seus valores de Meco\% foram inferiores ao limite máximo estabelecido. Dentre estas, as progênies $2,4,6,7,8,14,17$ e 18 apresentaram ainda menores desvios padrões que o da testemunha IAC-11, aumentando as possibilidades para a estabilidade fenotípica. Com relação à testemunha mais estável (IAC-8), 11 progênies foram superiores, apresentando menores Meco\%; porém apenas sete progênies tiveram também menores desvios padrões que o da testemunha mais estável IAC-8. Tais resultados elucidam o bom comportamento quanto à estabilidade fenotípica para as progênies do CMST.

\subsection{Análise de médias e desvios padrões dos genótipos}

Esta análise possui como principal objetivo caracterizar os genótipos que apresentaram comportamentos mais promissores para os caracteres avaliados, através das maiores médias principalmente para VA e PG, que são os caracteres mais relacionados valor produtivo. Para os caracteres Ac e CHS, as progênies de destaque terão que apresentar menores médias, já que os menores valores (nota 1) indicam plantas eretas e sem sintomas da doença CHS. Quanto à NDM e APM, estes vão variar de acordo com o CM avaliado, sendo esperado que quanto maior o $\mathrm{CM}$, maior serão as médias destes caracteres.

O desvio padrão por sua vez, será utilizado para se avaliar a variabilidade existente dentro das progênies para os diferentes caracteres. Para a avaliação associada à estabilidade, seria ideal a obtenção de menores desvios padrões dos genótipos, porém, como as médias foram obtidas a partir de dados das gerações $F_{4}, F_{5}$ e $F_{6}$, poderá ser detectada ainda variabilidade nestas progênies, principalmente se for considerada a origem através de cruzamentos múltiplos, que incluiu um número muito grande de parentais na genealogia, fato que pode retardar um pouco o processo de fixação dos genes. De acordo com Yokomizo (1999), os valores de desvios padrões encontrados dentro das progênies, representaria a variabilidade disponível, quando estes superarem as médias de desvios padrões obtidas nas testemunhas, que seria um referencial para a variabilidade ambiental. Vale lembrar ainda que as testemunhas utilizadas foram 
originadas através de cruzamentos biparentais, possuindo, portanto, tendência para base genética inferior a das progênies testadas (cruzamentos óctuplos).

As análises de médias e desvios padrões foram realizadas para cada $\mathrm{CM}$ e, dentro destes, para todos os caracteres avaliados (NDM, APM, Ac, VA, CHS e PG). Pelo teste de Dunnett, em algumas situações, não foi possivel diferenciar as progênies das médias das testemunhas, apesar de haver diferenças, portanto serão citadas apenas as que foram distinguidas. Este teste encontra-se nas Tabelas 32, 33, 34 e 35 juntamente com as médias e desvios padrões dos CMP, CMSP, CMI e CMST respectivamente, e as progênies diferenciadas estão marcadas por um asterisco.

\subsubsection{Grupo Precoce}

As progênies do CMP utilizadas para obtenção das médias e desvios padrões são as mesmas utilizadas nas análises conjuntas e na análise de estabilidade, portanto, totalizam 17 progênies comuns a todos os ambientes avaliados. Os valores obtidos nesta análise para o CMP encontram-se na Tabela 32.

O caráter número de dias para a maturidade (NDM) possui importância para a classificação das progênies em diferentes $\mathrm{CM}$. Recentemente, têm sido crescente o interesse por cultivares mais precoces, que permitam realizar mais que um plantio de soja por ano, ou que permitam a utilização de sistemas de rotação de culturas. Portanto, um maior número de progênies com médias de NDM menores que as testemunhas constitui-se em fato interessante para o melhoramento. No presente estudo, as médias de NDM para as progênies do CMP variaram de 119 a 135 dias, indicando que ainda existe uma variação para NDM dentro deste $\mathrm{CM}$. As progênies com menores médias de NDM foram as de número $1,4,6,8,10,11,14,15,16$ e 17, apresentando médias entre $119 \mathrm{e}$ 123 dias, ou seja, $59 \%$ das progênies apresentaram-se como mais precoces que a média geral das progênies (Mp) que foi de 124 dias. A média das testemunhas (Mt) Primavera e IAS-5 foi 121 dias, significando que $35 \%$ das progênies $(1,4,8,14,16$ e 17$)$ tiveram comportamento igual ou mais precoce que esta média (Tabela 32). Quanto ao desvio padrão, as progènies menos variáveis ou mais estáveis foram as de número $1,4,6,7,8$, 
15 e 17; portanto, apenas a progênie 7 não estava entre as mais precoces já citadas. Entretanto, apenas duas progênies apresentaram desvios menores que o desvio padrão médio das testemunhas (Mt) de 4,04; que foram as progênies 6 e 15 .

Com relação ao caráter altura da planta na maturidade (APM), considera-se que a altura mínima desejada para um cultivar comercial, que provavelmente será submetida à colheita mecanizada é de $60 \mathrm{~cm}$ (São Paulo, 1990); além disso, visualmente, genótipos mais altos possuem melhor aparência em termos agronômicos e produtivos, devido à correlação positiva entre APM e PG pelo aumento de internódios produtivos. Por outro lado, a APM deve ser elevada, desde que não interfira no acamamento, já que é conhecida a correlação positiva também existente entre APM e Ac, conforme será tratado mais adiante. Com relação às progênies do $\mathrm{CMP}$, com exceção da número $1(\mathrm{APM}=57 \mathrm{~cm})$, todas as demais apresentaram médias de APM acima de $60 \mathrm{~cm}$ (Tabela 32 ), variando entre 60,4 (progênie 4) e $112 \mathrm{~cm}$ (progênie 12), sendo a média obtida nas progênies de $80,31 \mathrm{~cm}$ e a média das testemunhas de $87,20 \mathrm{~cm}$. As progênies $2,3,5,6,7$, $9,10,11,12,13,15,16$ e 17 apresentaram alta variabilidade para APM, com desvios variando de 14,71 (progênie 5) a 24,46 (progênie 15), valores estes maiores que o desvio padrão médio das testemunhas de 14,62 .

Para o caráter Ac, onde as notas variaram de 1 a 5 , estes valores são atribuidos de acordo com a inclinação da haste principal da planta em relação ao solo no campo, de modo que uma planta perfeita seria aquela isenta de inclinação, ou seja, formando um ângulo de $90^{\circ} \mathrm{com}$ o solo, para a qual seria atribuida nota 1 . Plantas completamente acamadas (nota 5) encostam no solo, causando perdas na produtividade, pelo fato das vagens que tocam o solo sofrerem apodrecimento, além de não permitirem uma perfeita colheita mecanizada. Conforme mencionado, um dos fatores que aumentam o Ac é a elevada APM; portanto, deve-se procurar progênies com APM intermediárias que não reduzam a produtividade final de grãos e, por outro lado, que não sejam suscetíveis ao Ac. De qualquer forma, para o caráter Ac, menores médias são desejadas, já que isto significa plantas mais eretas. As análises foram realizadas com os dados originais e transformados, de modo que as discussões serão em torno das médias dos dados originais e dos desvios padrões dos dados transformados. Quando se observa a média 
das testemunhas $(1,55)$ nota-se que a média das progênies não superou em muito já que foi de 1,66 (Tabela 32). Nota-se ainda que as progênies $1,2,3,4,6,7,8,9,11$ e 14, ou seja, 59\% das progênies deste CM, apresentaram médias menores que a média das testemunhas citadas. Com relação ao desvio padrão das testemunhas, que foi de 0,18 ; este foi superado pelas progênies $2,5,10,12,15,16$ e 17 , com desvios entre 0,2852 e 0,3994, indicando a variabilidade disponível para este caráter presente nestas progênies.

As notas de valor agronômico (VA) atribuidas aos genótipos possuem como objetivo, tentar reunir ao máximo neste caráter todas as características agronômicas principais que podem ser analisadas visualmente, tais como, a capacidade produtiva, a reação à doenças, a retenção foliar e presença de hastes verdes, a debulha precoce, o acamamento e a altura ideal da planta. As notas portanto são subjetivas e variam de 1 (VA ruim) a 5 (VA excelente). As análises, assim como para o caráter Ac, foram feitas com os dados originais e transformados, sendo a discussão limitada às médias dos dados originais e os desvios padrões dos dados transformados. Porém, para este caráter, ao contrário de Ac, espera-se encontrar progênies com altas médias de VA. De acordo com o comportamento das progênies (Tabela 32), observa-se que as mais promissoras são as de número $2,3,4,7,8,14$ e 16 com VA's médios de 3,18 a 3,59, valores acima da média geral das progênies $(\mathrm{Mp})$ de 3,14, considerado um bom valor. Porém, nenhuma das progênies superou a média das testemunhas $(\mathrm{Mt})$ que foi de 3,63. Entretanto, para a variabilidade, as testemunhas com desvio médio transformado de 0,10 em muito foram superadas pelo grupo das progênies, onde com exceção da progênie 10 , todas as outras apresentaram desvios padrões superiores, evidenciando a variabilidade disponível.

A avaliação da reação a doença cancro-da-haste da soja (CHS), causada pelo fungo Diaporthe phaseolorum f.sp.meridionalis, tem se tornado de grande importância para o melhoramento da soja, por se tratar de uma das principais doenças dos campos de produção das últimas safras agricolas. Selecionando-se genótipos com resistência à doença, condicionada por dois genes dominantes (Siviero et al., 1997), diminuirão os riscos de incidências devastadoras do patógeno. Assim como para o caráter Ac, menores médias são desejadas, visto que são atribuídas nota 1 ao genótipo sem os sintomas e nota 4 para aquele com alta incidência do patógeno. Para o CMP em particular, pode ocorrer 
o escape, através do qual as plantas mostram-se sem os sintomas, pois são colhidas antes de serem atingidas as condições climáticas ideais para manifestação do patógeno no campo. Porém, ainda assim, nota-se que as avaliações podem ser feitas pois as condições climáticas oscilam frequentemente e, além disso, dentro do CMP pode ser detectada variabilidade e uma ampla faixa para NDM, conforme observado na discussão deste caráter. Aqui também foram analisados os dados originais e transformados, tomando-se para discussão as médias originais e os desvios transformados. Observa-se que as progênies com melhor comportamento foram as de número 1, 4, 11, 12, 14 e 16 (Tabela 32 ), todas com médias 1,0 , portanto, um pouco abaixo da média das testemunhas $(1,03)$. A progênie 1 (USP97-11.001) possui na sua genealogia o cultivar Primavera, que segundo Siviero et al.(1997) este parental possui genes de resistência ao CHS, existindo grandes chances da progênie 1 também possuir tal resistência. A média de todas as progênies foi de apenas 1,23, comprovando a baixa incidência desta doença em progênies com CM menores. Os desvios padrões das progênies $2,4,5,6,7,8,9,10,13$, 15 e 17 situaram-se acima do desvio médio das testemunhas $(0,04)$, indicando a presença de variabilidade também para a seleção deste caráter (Tabela 32).

$\mathrm{O}$ caráter produtividade de grãos $(\mathrm{PG})$ em todos os programas de melhoramento, é uma característica da maior importância, já que mede a produção final do genótipo testado, podendo-se avaliar se houve ou não ganhos no programa de melhoramento. Para a cultura da soja, onde os patamares de produtividade estão estabelecidos a algum tempo, torna-se de fundamental importância o melhoramento deste caráter. Tratando-se deste trabalho em particular, esta importância aumenta, principalmente para se avaliar se os cruzamentos óctuplos presentes na metodologia, poderão auxiliar na quebra destes patamares, através da comparação com as testemunhas utilizadas que são cultivares comerciais e que possuem como origem cruzamentos biparentais. As análises e discussões foram feitas com os transformados para $\mathrm{kg} / \mathrm{ha}$. Destacaram-se as progênies 1 , $2,3,4,5,12,14$ e 15 , com médias entre 2484 e $3071 \mathrm{~kg} / \mathrm{ha}$ valores estes acima da média geral das progênies $(2360 \mathrm{~kg} / \mathrm{ha})$; porém, nenhuma das progênies avaliadas conseguiu atingir a média das testemunhas para este $\mathrm{CM}$ que foi de $3165 \mathrm{~kg} / \mathrm{ha}$ (Tabela 32). Convém lembrar que estas médias refletem as performances gerais nos seis ambientes, 
podendo haver grandes variações entre ambientes. Observa-se ainda (Tabela 32) que a média da progênie $3(3071 \mathrm{~kg} / \mathrm{ha})$ foi pouco acima da testemunha Primavera $(3062 \mathrm{~kg} / \mathrm{ha})$, mas ficou abaixo da testemunha IAS-5 $(3268 \mathrm{~kg} / \mathrm{ha})$. Isto pode ser claramente observado na coluna adjacente a PGt (ainda na Tabela 32), onde os valores de \%PGp representam a superioridade de cada progênie em relação à média das progênies e os valores de \%PGt indicam a superioridade ou não das progênies em porcentagem, em relação à média das testemunhas.

Através do teste de Dunnett (Tabela 32), algumas progênies foram diferenciadas, para cada caráter em particular, sendo citadas a seguir de acordo com este critério:

NDM : № 1 (USP97-11.001), 2 (USP97-11.002), 3 (USP97-11.003), 4 (USP97-11.004),

5 (USP97-11.005), 7 (USP97-11.007), 9 (USP97-11.009), 12 (USP97$11.0012)$ e 13 (USP97-11.0013).

APM : № 1 (USP97-11.001), 2 (USP97-11.002), 3 (USP97-11.003), 4 (USP97-11.004), 6 (USP97-11.006), 8 (USP97-11.008), 11 (USP97-11.011), 12 (USP9711.0012), 14 (USP97-11.0014) e16 (USP97-11.0017).

Ac : № 5 (USP97-11.005), 10 (USP97-11.010), 12 (USP97-11.0012), 15 (USP9711.0015) e16 (USP97-11.0017) e 17 (USP97-11.0016).

VA : № 5 (USP97-11.005), 6 (USP97-11.006), 11 (USP97-11.011), 12 (USP9711.0012) e 13 (USP97-11.0013).

CHS : № 6 (USP97-11.006), 7 (USP97-11.007) e 13 (USP97-11.0013).

PG : № 3 (USP97-11.003) e 11 (USP97-11.011).

\subsubsection{Grupo Semi-Precoce}

Na Tabela 33 podem ser analisados os resultados obtidos na análise de médias e desvios padrões do CMSP, onde se nota que os tratamentos utilizados foram os mesmos da análise conjunta total e da análise de estabilidade fenotípica, totalizando 30 progênies e duas testemunhas, que foram comuns em todos os experimentos instalados nos seis ambientes. 
As considerações gerais feitas no CMP a respeito dos caracteres avaliados são válidas para todos os $\mathrm{CM}$. Portanto, nos demais $\mathrm{CM}$ os resultados serão discutidos de forma mais direta.

As análises para NDM indicaram, como já era esperado, um aumento de média para este caráter comparando-se com o CMP, tanto nas progênies como nas testemunhas, apresentando médias respectivas de 127 e 125 dias. As progênies 2, 3, 4, 5, $10,17,18,19,21,23,24,26,27$ e 29 (47\% do total) apresentaram médias iguais ou abaixo das testemunhas; logo, foram as mais precoces do grupo, com NDM variando de 122 a 125 dias. As progênies mais tardias foram a 6,8,9,11, 13 e 15, com médias de 130 a 132 dias. As médias dos desvios padrões foram de 4,54 para progênies e 3,29 para testemunhas; apenas as progênies 4, 18, 19, 21, 24, 26, 27 e 29 (27\%) apresentaram variabilidade abaixo das testemunhas; portanto, existe grande variabilidade disponivel para NDM na grande maioria das progênies.

As médias obtidas para APM no grupo das progênies do CMSP foi de $86,1 \mathrm{~cm}$ e nas testemunhas foi de $83,4 \mathrm{~cm}$ (Tabela 33). As progênies 4, 6, 7, 8, 11, 13, 14, 20, 21, $23,24,25,26,28,29$ e 30 revelaram valores de APM acima das testemunhas avaliadas; além disso, todas as progênies foram superiores ao limite mínimo de $60 \mathrm{~cm}$. As médias entre as progênies variaram de 85,1 a $102,9 \mathrm{~cm}$. Os desvios padrões foram de 15,36 para progênies e 17,0 para testemunhas, sendo observado que apenas as progênies $1,4,6,8$, $9,14,20$ e 24 apresentaram variabilidade disponível para este caráter, ou seja, demonstraram desvios padrões maiores que o desvio médio das testemunhas. Nota-se que as progênies $4,6,8,14,20$ e 24 possuem tanto as maiores médias quanto os maiores desvios para APM.

Para os três próximos caracteres (Ac, VA e CHS) serão utilizadas na discussão, as médias dos dados originais e os desvios padrões dos dados transformados.

Analisando as médias de Ac, observa-se que as progênies acamaram menos que as testemunhas, apresentando uma média de 1,62 enquanto a média das testemunhas foi de 1,85 (Tabela 33). Apenas as progènies $3,4,7,17,20,23,24,25,26$ e 30 (33\% do total) apresentaram médias superiores à média das testemunhas, sendo destacadas as progênies $12,15,18,21,22,27$ e 29 que apresentaram níveis de acamamento mais 
satisfatórios do que a melhor testemunha (BR-16 $=1,33$ ). Quanto ao desvio padrão, o das testemunhas foi acima do das progênies, sendo de 0,26 e 0,20 respectivamente. Apenas as progênies $3,4,17,23,24$ e 25 apresentaram variabilidade disponivel para Ac, pois suas médias superaram a média das testemunhas.

No caráter VA, observou-se que as progênies não superaram em média as testemunhas, respectivamente com médias de 3,24 e 3,60 (Tabela 33). Apenas as progênies 21 e $29(\mathrm{VA}=4,0$ e 3,77) situaram-se acima da média de VA das testemunhas BR-16 $(3,61)$ e IAC-Foscarin-31 $(3,60)$. Contudo, a variabilidade foi muito superior nas progênies que nas testemunhas, com desvios médios de 0,16 e 0,15 , respectivamente. Das 30 progênies avaliadas, 17 (57\% do total) apresentaram um desvio padrão acima do desvio médio das testemunhas para o caráter VA.

Quanto à reação a doença cancro-da-haste (CHS), as testemunhas demonstraramse mais resistentes que as progênies, pois enquanto sua média foi de 1,05 as progênies atingiram uma média de 1,37 na escala de notas atribuídas. Porém, esta média atingida pelas progênies não é uma média considerada alta, podendo ser aceitável. Entre as progênies, destacaram-se as de número 11 e 29 , que a exemplo da testemunha IACFoscarin-31 receberam nota 1,0 em todas as parcelas avaliadas, comprovando a ausência total de incidência da doença nestes genótipos; tal fato foi confirmado pelo desvio padrão nulo apresentado por todos os três genótipos. A PSP 29 (cruzamento 44), tal como a PPR 1 (cruzamento 1) possui na sua genealogia o parental resistente Primavera (Siviero et al., 1997), com grandes chances portanto, de possuir os dois genes de resistência para CHS. As progênies mais preocupantes são as de número 3, 7, 13 e 22; com médias mais altas (entre 1,73 e 2,0). Devido ao desvio nulo da testemunha IACFoscarin-31, a média dos desvios entre elas ficou muito baixa $(0,07)$ sendo superada por todas as PSP testadas, exceto as progênies já citadas 11 e 29 que não apresentaram qualquer sintoma da doença. Portanto, as progênies mostraram muita variabilidade disponivel para CHS.

A produtividade média de grãos (PG) para o CMSP foi de $2441 \mathrm{~kg} / \mathrm{ha}$ para as progênies e de $2712 \mathrm{~kg} /$ ha para as testemunhas (Tabela 33). Quando se observa a coluna de $\% \mathrm{PGp}$, nota-se que as progênies $1,5,6,9,12,15,16,18,21,25,27$ e 28 foram mais 
produtivas que a média das progênies; já na coluna de \%PGt observa-se que as progênies $5,12,21$ e 28 destacaram-se com médias iguais ou superiores à média das testemunhas BR-16 e IAC-Foscarin-31. Os desvios padrões observados, em média, foram menores nas progênies que nas testemunhas apresentando desvio médio de 749,15 e $940,18 \mathrm{~kg} / \mathrm{ha}$ respectivamente. Apenas a progênie $25 \mathrm{com}$ desvio de $1015,6 \mathrm{~kg} / \mathrm{ha}$ superou o desvio médio das testemunhas; apesar disto, existiu boa estabilidade para PG nas PSP, comprovada pela variação menor ou próxima à ocorrida nas testemunhas.

As progênies do CMSP discriminadas pelo teste de Dunnett (Tabela 33) são citadas a seguir para cada caráter separadamente :

NDM : № 6 (USP97-11.026), 7 (USP97-11.027), 8 (USP97-11.032), 9 (USP97-11.034), 11 (USP97-11.041), 12 (USP97-11.044), 13 (USP97-11.042), 14 (USP9711.043), 15 (USP97-11.047), 16 (USP97-11.023), 20 (USP97-11.035), 22 (USP97-11.039), 25 (USP97-11.028), 28 (USP97-11.036) e 30 (USP9711.046)

APM : No 11(USP97-11.041), 13 (USP97-11.042), 20 (USP97-11.035), 26 (USP9711.029), 28 (USP97-11.036) e 30 (USP97-11.046).

Ac : № 4 (USP97-11.022), 7 (USP97-11.027), 20 (USP97-11.035) e 23 (USP97-11.040) VA : № 3 (USP97-11.020), 7 (USP97-11.027), 8 (USP97-11.032), 9 (USP97-11.034), 13 (USP97-11.042), 15 (USP97-11.047), 19 (USP97-11.031), 20 (USP9711.035), 22 (USP97-11.039), 23 (USP97-11.040), 24 (USP97-11.021) e 25 (USP97-11.028).

CHS : № 3 (USP97-11.020), 7 (USP97-11.027), 8 (USP97-11.032), 13 (USP97-11.042) e 22 (USP97-11.039).

PG : Nenhuma PSP superou a média de PG das testemunhas.

\subsubsection{Grupo Intermediário}

Neste CM, foram analisadas as 60 progennies e três testemunhas (Bossier, IAC100 e IAC-12) que também estiveram presentes na análise conjunta e de estabilidade 
fenotípica, as quais foram comuns em todos os experimentos instalados do CMI nos três anos agrícolas.

Os critérios adotados foram os mesmos utilizados para as análises dos CMP e CMSP que já foram discutidos.

Os resultados obtidos para NDM (Tabela 34)revelaram que a média das testemunhas foi menor (134 dias) do que a média geral das progênies (139 dias), onde apenas as progênies 21 e 40 igualaram suas médias às médias das testemunhas (134 dias); todas as demais progênies foram mais tardias que as testemunhas, com ciclos variando de 135 (progênies 30, 42, 45, 54 e 58) a 145 dias (progênies 1 e 52). Os desvios padrões, por sua vez, superaram o desvio padrão médio das testemunhas $(2,82)$ e tiveram variações desde 2,94 (progênie 31) a 7,64 dias (progênie 26), evidenciando a grande variabilidade disponivel presente nas PIN para NDM.

Seguindo a mesma tendência de NDM, o caráter APM apresentou média geral maior no grupo das progênies do que no grupo das testemunhas, com médias respectivas de 97,14 e 73,23 cm (Tabela 34). Todas as progênies atingiram uma altura maior que 60 $\mathrm{cm}$, que é o limite mínimo. A progênie 24 foi a única que não conseguiu superar a média das testemunhas, atingindo uma média de APM de apenas $72,5 \mathrm{~cm}$; todas as demais superaram a média citada com valores de $77,2 \mathrm{~cm}$ (progênie 39 ) a $117,9 \mathrm{~cm}$ (progênie 41). Em contrapartida, o grupo das testemunhas apresentou desvio padrão médio superior ao grupo das progênies, respectivamente 15,16 e $13,51 \mathrm{~cm}$. Um grupo de 20 progênies que representou $33 \%$ do total (progênies 1, 10,11, 12, 14, 17, 20, 23, 25, 26, $27,30,39,41,43,45,46,47,56$ e 57) obtiveram desvios médios maiores que o desvio das testemunhas, com valores de 15,30 a $22,04 \mathrm{~cm}$, indicando que neste $\mathrm{CM}$ também existe variabilidade disponível para APM, porém esta não foi suficiente para superar o desvio médio das testemunhas.

Para o carater Ac (Tabela 34), médias maiores foram obtidas analisando-se os dados originais, no grupo das progênies $(1,80)$ do que no grupo das testemunhas $(1,38)$. Isto já podia ser esperado, em função das maiores médias obtidas no caráter APM no grupo das progênies comparadas ao grupo das testemunhas, já que os dois caracteres são positivamente correlacionados, como mencionado anteriormente. Entretanto, médias de 
Ac menores que a do grupo das testemunhas puderam ser detectadas nas progênies 7,21 , $22,24,29,30,43,48,51$ e 56 , perfazendo um total de $17 \%$ de progênies destaques em Ac, cujas médias variaram de 1,05 a 1,32. O desvio padrão obtido com os dados transformados também foi mais alto no grupo das progênies $(0,22)$ comparado às testemunhas $(0,20)$, observando-se entretanto que 29 das 60 progênies não superaram o desvio médio das testemunhas para este caráter; todas as progênies citadas como destaques com menores médias de Ac, estiveram dentro do grupo das progênies com desvios menores que as testemunhas.

As notas atribuídas ao caráter VA (Tabela 34), revelaram maiores médias nos dados originais, no grupo das testemunhas com 3,69 do que no grupo das progênies com 3,23 ; porém devido à variabilidade presente entre as progênies, pôde-se verificar médias acima de 3,69 nas progênies $13(3,82), 21(4,0), 47(3,73)$ e $56(3,91)$, consideradas excelentes médias para VA. Entretanto, analisando todo o grupo das progênies, e adotando-se 3,5 como um critério satisfatório, nota-se que um grupo de nove progênies além das destacadas, igualaram-se ou superaram o valor de 3,5; isto sugere um ótimo comportamento geral das PIN, avaliado através de VA. Quanto ao desvio padrão, nos dados transformados, obteve-se menor média nas testemunhas $(0,10)$ do que nas progênies $(0,17)$, onde apenas as de número $21,49,50$ e 56 apresentaram menores desvios que as testemunhas, todas as demais progênies apresentaram variabilidade disponível para VA.

Observou-se que a doença CHS incidiu mais no grupo das progênies onde a média foi de 1,5 do que no grupo das testemunhas com média de 1,19 (Tabela 34). Isto se explica pelo fato das testemunhas serem genótipos reconhecidamente resistentes a tal doença, enquanto as progênies ainda estão em fase de teste, podendo haver genótipos resistentes e suscetíveis. Realmente, as progênies $12,16,20,21,29,40,41,42,43,45$, $46,47,49,50,56$ e 58 ( $27 \%$ do total) apresentaram menores médias que as testemunhas, portanto menores incidências da doença; destacaram-se as progênies $16,20,21,40,42$, $43,46,47,56$ e 58 com médias de notas 1,0 e desvio zero, ou seja, não apresentaram quaisquer sintomas da doença em todas as parcelas avaliadas de todos os seis experimentos. As progênies 21 (cruzamento 44), 40 (cruzamento 24), 42 e 43 
(cruzamento 25) e a número 58 (cruzamento 45) possuem nas genealogias o parental resistente Primavera (Siviero et al., 1997), tendo assim grandes chances de apresentarem resistência ao CHS. Os desvios padrões médios dos dados transformados foram mais altos no grupo das progênies $(0,21)$ do que no das testemunhas $(0,14)$, com apenas 13 progênies ou $22 \%$, apresentando menor variabilidade que as testemunhas para $\mathrm{CHS}$.

Com relação à PG (Tabela 34), as progênies tiveram em média produtividade um pouco inferior à das testemunhas, com $2791 \mathrm{~kg} / \mathrm{ha}$ para as progênies e $2837 \mathrm{~kg} / \mathrm{ha}$ para as testemunhas. As médias de PG podem estar relacionadas às médias de CHS. Porém, devido à grande variabilidade presente para $\mathrm{PG}$, e em função do maior número de progênies avaliadas neste $\mathrm{CM}$ do que nos anteriores, na coluna de \% $\mathrm{PGp}$ verifica-se que $50 \%$ das progênies pertenciam ao grupo que possuíam PG acima da média geral delas, na coluna de \%PGt observa-se que as progênies $3,4,5,6,13,15,16,20,21,22,26,34$, $40,41,42,45,46,47,48,52,53,54,55,56,57$ e 58 superaram também a média das testemunhas quanto à $\mathrm{PG}$, totalizando $43 \%$ de progênies superiores. Os desvios padrões médios estiveram bem próximos para os dois grupos com $772,31 \mathrm{~kg} / \mathrm{ha}$ para progênies e $779,92 \mathrm{~kg} / \mathrm{ha}$ para testemunhas. Do total, 27 progênies apresentaram desvios padrões superiores à média das testemunhas, revelando variabilidade disponivel para PG, nas PIN.

As PIN distinguidas da média das testemunhas pelo teste Dunnett (Tabela 34) são listadas a seguir para os referidos caracteres:

NDM : № 1 (USP97-11.052), 3 (USP97-11.056), 4 (USP97-11.060), 5 (USP97-11.061), 6 (USP97-11.062), 7 (USP97-11.063), 8 (USP97-11.064), 9 (USP9711.066), 10(USP97-11.075), 11(USP97-11.081), 12(USP97-11.082), 13 (USP97-11.084), 14(USP97-11.085), 15 (USP97-11.090), 16 (USP9711.092), 19 (USP97-11.095), 20 (USP97-11.096), 22 (USP97-11.098), 23 (USP97-11.099), 25 (USP97-11.103), 26 (USP97-11.105), 27 (USP9711.106), 28 (USP97-11.048), 31 (USP97-11.053), 32 (USP97-11.055), 34 (USP97-11.058), 35 (USP97-11.065), 36 (USP97-11.067), 37 (USP9711.068), 38 (USP97-11.070), 39 (USP97-11.071), 44 (USP97-11.079), 46 (USP97-11.086), 47 (USP97-11.087), 48 (USP97-11.091), 49 (USP97- 
11.102), 50 (USP97-11.050), 51 (USP97-11.059), 52 (USP97-11.069), 56 (USP97-11.088), 59 (USP97-11.104) e 60 (USP97-11.107).

APM : Todas as progênies foram diferenciadas pelo teste Dunnett, exceto a № 24 (USP97-11.100) e 39 (USP97-11.071).

Ac : № 1 (USP97-11.052), 3 (USP97-11.056), 5 (USP97-11.061), 8 (USP97-11.064), 10(USP97-11.075), 11(USP97-11.081), 15 (USP97-11.090), 18 (USP9711.094), 20 (USP97-11.096), 23 (USP97-11.099), 25 (USP97-11.103), 26 (USP97-11.105), 27 (USP97-11.106), 28 (USP97-11.048), 31 (USP97-11.053), 32 (USP97-11.055), 33 (USP97-11.057), 34 (USP97-11.058), 35 (USP9711.065), 36 (USP97-11.067), 37 (USP97-11.068), 38 (USP97-11.070), 40 (USP97-1 1.074), 41 (USP97-11.076), 44 (USP97-11.079), 45 (USP97-11.083), 46 (USP97-11.086), 52 (USP97-11.069), 54 (USP97-11.073), 55 (USP9711.080), 57 (USP97-11.088), 59 (USP97-11.104) e 60 (USP97-11.107).

VA : № 1 (USP97-11.052), 3 (USP97-11.056), 4 (USP97-11.060), 8 (USP97-11.064), 10(USP97-11.075), 11(USP97-11.081), 15 (USP97-11.090), 18 (USP9711.094), 23 (USP97-11.099), 24 (USP97-11.100), 25 (USP97-11.103), 26 (USP97-11.105), 27 (USP97-11.106), 28 (USP97-11.048), 32 (USP97-11.055), 33 (USP97-11.057), 36 (USP97-11.067), 37 (USP97-11.068), 38 (USP9711.070), 39 (USP97-11.071), 41 (USP97-11.076), 44 (USP97-11.079), 45 (USP97-11.083), 52 (USP97-11.069), 54 (USP97-11.073), 55 (USP97-11.080), 57 (USP97-11.088), 59 (USP97-11.104) e 60 (USP97-11.107).

CHS : № 1 (USP97-11.052), 4 (USP97-11.060), 5 (USP97-11.061), 6 (USP97-11.062), 14 (USP97-11.085), 18 (USP97-11.094), 25 (USP97-11.103), 26 (USP9711.105), 27 (USP97-11.106), 32 (USP97-11.055), 33 (USP97-11.057), 34 (USP97-11.058), 36 (USP97-11.067), 39 (USP97-11.071), 54 (USP9711.073), 59 (USP97-11.104) e 60 (USP97-11.107).

PG : № 13 (USP97-11.084), 21 (USP97-11.097), 41 (USP97-11.076) e 53 (USP97$11.072)$. 


\subsubsection{Grupo Semi-Tardio}

Foram submetidas a esta análise, 20 progênies e três testemunhas (IAC-11, IAC4 e IAC-8) coincidentes com os genótipos utilizados nas análises conjuntas e de estabilidade fenotípica, que foram comuns a todos os ambientes avaliados. As considerações feitas no CMP sobre os caracteres avaliados, são válidas para o CMST, assim como ocorreu no CMSP e CMI.

Como este grupo possui o maior $\mathrm{CM}$ dentre os grupos avaliados, ocorreram as maiores médias para NDM, sendo a média das progênies (144 dias) superior à média das testemunhas (141 dias) (Tabela 35), a progênie 3 (141 dias) foi semelhante às testemunhas, e as demais progênies foram mais tardias, com variações de 142 (progênie 7) a 148 dias (progênie 11). A variabilidade observada através do desvio padrão foi superior nas progênies (5,65 dias de desvio médio), do que nas testemunhas (desvio médio de 5,30 dias). As progênies $3,8,9$ e 12 não superaram o desvio médio das testemunhas; entretanto, todas as outras 16 progênies superaram as testemunhas, apresentando variabilidade disponível para NDM.

Como ocorreu no CMI, o caráter APM acompanhou a tendência de NDM e apresentou média de progênies superior à das testemunhas (Tabela 35). As médias foram de 101,22 e $98,28 \mathrm{~cm}$ para progênies e testemunhas respectivamente. Das 20 progênies avaliadas, 13 foram superiores à média das testemunhas, com apenas as progênies 1,4 , $12,15,16,17$ e 18 sendo menores que esta. Dentre as superiores, o caráter APM variou de 99,6 a $125,8 \mathrm{~cm}$, valores estes considerados elevados. Conforme observado, todas as progênies ficaram bem acima do limite mínimo de $60 \mathrm{~cm}$. O desvio padrão médio foi mais elevado nas progênies com $14,17 \mathrm{~cm}$ e as testemunhas apresentando $13,80 \mathrm{~cm}$. As progênies $1,2,3,6,7,13,14,15$ e 17 apresentaram desvios médios menores que o desvio das testemunhas, enquanto as demais progênies foram superiores em variabilidade.

Assim como nos outros $\mathrm{CM}$, os próximos caracteres Ac, VA e CHS serão discutidos utilizando-se as médias dos dados originais e os desvios padrões dos dados transformados. 
De acordo com a Tabela 35, apesar da maior média de APM nas progênies, o que poderia levar a uma maior ocorrência de acamamento, observou-se menor média de Ac nas progênies $(1,83)$ do que nas testemunhas $(2,26)$. Portanto, a elevada altura não fez com que as plantas acamassem muito, provavelmente devido a boa estrutura morfológica (diâmetro da haste, fibras, lignina) das plantas avaliadas. Além disso, os resultados apontam que somente quatro das 20 progênies $(3,7,11$ e 16) superaram o Ac médio das testemunhas; portanto, 16 progênies ( $80 \%$ do total) acamaram menos que os genótipos padrões, com médias de notas entre 1,18 (progênie 17) e 2,23 (progênie 10). Os desvios padrões mais elevados estiveram presentes no grupo das testemunhas $(0,31)$, estando próximo ao obtido pelas progênies $(0,24)$. As progênies 3 e 7 foram as únicas que apresentaram variabilidade disponível entre as progênies para Ac (desvios entre 0,3899 e 0,3955 ).

As notas atribuídas ao VA (Tabela 35 ) revelaram que a média geral das progênies de 2,99 superou a média das testemunhas $(2,90)$. Isto é um ótimo resultado, considerando que o VA mede o potencial agronômico total dos genótipos; das 20 progênies, 13 superaram o VA médio da testemunhas, com médias entre 2,91 (progênie 13) e 3,82 (progênie 17), significando que $65 \%$ das progênies são superiores. O desvio padrão médio foi similar entre progênies e testemunhas, sendo de 0,17 para ambas. Do total das progênies, nove apresentaram maior variabilidade que as testemunhas, com desvios médios variando de 0,1880 (progênie 11) a 0,2486 (progênie 19).

Para o caráter CHS (Tabela 35), a média geral obtida entre progênies de 1,61 foi inferior à média das testemunhas $(1,75)$. Tal fato foi surpreendente, pois, como as testemunhas são genótipos reconhecidamente resistentes para tal doença, esperava-se médias menores do que nas progênies, principalmente por se tratar do $\mathrm{CM}$ com maior ocorrência da doença. Apenas as progênies 3, 7, 10, 16, 18 e 20 apresentaram maior vulnerabilidade à doença CHS do que as testemunhas, variando suas médias de 1,82 (progênie 10) a 2,36 (progênie 7); as demais apresentaram menores médias. Os desvios padrões médios obtidos nas progênies também foi inferior ao das testemunhas, sendo de 0,24 e 0,32 , respectivamente. Apenas as progênies 3,10,16 e 20 que pertenceram ao grupo das maiores médias para CHS, apresentaram variabilidades iguais ou superiores às 
testemunhas. Os maiores destaques para CHS (menores médias) foram para as progênies 1 (cruzamento 10) e 17 (cruzamento 31) apesar de não apresentarem o parental resistente Primavera na sua genealogia.

A capacidade produtiva avaliada por PG neste CM apresentou maior média geral no grupo das progênies do que no grupo das testemunhas, com $2817 \mathrm{~kg} / \mathrm{ha}$ para as progênies e $2649 \mathrm{~kg} / \mathrm{ha}$ para as testemunhas, equivalendo a $6 \%$ de superioridade em média (Tabela 35). Este resultado é de grande importância, em razão das testemunhas comparadas (IAC-11, IAC-4 e IAC-8) serem cultivares comerciais conhecidas e de boas performances. Quando se analisa a coluna \%PGp (Tabela 35) pode-se concluir que as progênies $2,7,8,9,10,13,16,17,18$, e 20 são os genótipos que possuem PG acima da média do grupo, ou seja, dez das 20 progênies (50\%) produziram mais que $2817 \mathrm{~kg} / \mathrm{ha}$, variando de 2844 (progênie 10) a $3119 \mathrm{~kg} /$ ha (progênie 9). Estes valores são ainda maiores para a coluna de \%PGt, já que a média das testemunhas foi menor, levando a conclusão de que 17 progênies ( $85 \%$ do total) foram superiores à média das testemunhas, para o caráter PG. Os desvios padrões observados foram superiores também nas progênies $(732,14)$ comparadas às testemunhas $(704,94)$, com 13 progênies apresentando variabilidade disponivel para $\mathrm{PG}$, pois superaram o desvio médio das testemunhas.

As progênies diferenciadas pelo teste Dunnet (Tabela 35), para os referidos caracteres são listadas a seguir:

NDM : Nenhuma PST pôde ser diferenciada das testemunhas pelo teste Dunnett para NDM.

APM : № 8 (USP97-11.116), 9 (USP97-11.118), 10 (USP97-11.120), 11(USP9711.117), 17 (USP97-11.119), 18 (USP97-11.121), 19 (USP97-11.125.

Ac : № 1 (USP97-11.109), 15 (USP97-11.126), 17 (USP97-11.119), 20 (USP97-11.127) VA : № 1 (USP97-11.109), 2 (USP97-11.110), 14 (USP97-11.124), 17 (USP97-11.119). CHS : № 7 (USP97-11.115).

PG : № 1 (USP97-11.109), 4 (USP97-11.112), 5 (USP97-11.113), 9 (USP97-11.118), 11(USP97-11.117), 15 (USP97-11.126), 19 (USP97-11.125), 20 (USP9711.127). 


\subsection{Associação entre a análise de médias e estabilidade}

Para esta discussão utilizou-se os valores de ecovalência médios (Meco\%) e desvios padrões das ecovalências (Seco\%), associando-se a estes os valores de médias obtidos para os caracteres, de cada progênie de todos os CM De modo a realizar uma seleção mais branda, será utilizado como padrão o maior valor de ecovalência médio obtido nas testemunhas, admitindo-o como limite máximo para classificar um genótipo como estável. Com relação às médias, os principais caracteres levados em conta foram NDM, Ac, VA, CHS e PG. As médias desejadas para tais caracteres seriam valores menores para NDM, Ac e CHS (progênies mais precoces, menos acamadas e com ausência ou sintomas mínimos de CHS) e valores maiores para VA e PG (progênies mais favoráveis em performance agronômica e produtividade).

No CMP, conforme comentado, nenhuma das progênies seria considerada estável, já que todas superaram o limite máximo de $M e c 0 \%=2,18$ da testemunha Primavera (Tabela 30). Porém, as progênies mais estáveis foram as PPR 4 (USP9711.004) e a PPR 16 (USP97-11.017), com as menores Meco\% e Seco\% deste CM. Analisando suas médias (Tabela 32), observa-se que a PPR 4 foi uma das mais precoces (119 dias), além disto apresentou uma baixa média de Ac (1,09), ausência de sintomas

de CHS $(1,00)$ e médias satisfatórias de VA $(3,45)$ e PG $(2565 \mathrm{~kg} / \mathrm{ha})$, superando a média das progênies em $9 \%$. A PPR 16 , a segunda mais estável, também merece destaque pela precocidade (121 dias) e pela ausência de sintomas de CHS, apresentando média 1,00 e variância zero. A progênie de melhor produtividade foi a PPR 3 (USP97$11.003)$, com $3071 \mathrm{~kg} / \mathrm{ha}$, com estabilidade regular $\left(13^{*}\right.$ colocada) e praticamente ausência de sintomas de CHS (média 1,09).

No CMSP (Tabela 30), adotando-se o limite máximo de Meco $\%=4,89$, observase que apenas as PSP 7 e 19 excederam este limite, ou seja, 93\% das progênies foram mais estáveis que BR-16 e 14 progênies (47\%) foram mais estáveis que a testemunha mais estável IAC-Foscarin-31 (Meco\%=3,00). Dentre estas, as PSP 2 (USP97-11.019), 12 (USP97-11.044), 16 (USP97-11.023), 17 (USP97-11.024) e 18 (USP97-11.030), apresentaram também menores desvios de ecovalência que a melhor testemunha. Os 
maiores destaques relativos às médias foram para as PSP 2 e 18, apresentando-se com precocidade igual ou maior que a média das testemunhas (125 dias), com menor acamamento $(M t=1,85)$ e com médias de CHS bem inferiores às médias gerais das progênies $(1,37)$. As médias de VA de tais progênies superaram à média das progênies $(3,24)$ e estiveram próximas à média das testemunhas $(3,60)$. A quarta melhor estabilidade do grupo (PSP 12), foi também a progênie de melhor PG (2788 kg/ha), excedendo a média das progênies em $14 \%$ e a das testemunhas em $3 \%$, superando todas as outras progênies e a testemunha BR-16 e perdendo apenas para a testemunha IACFoscarin-31 (Tabela 32).

No CMI, adotando-se como limite máximo a estabilidade média da testemunha IAC-12 (Meco\%=1,72), conforme se observa na Tabela 31, 39 das 60 progênies são consideradas estáveis. Comparando-se à testemunha mais estável (Bossier, com Meco\%=0,91), observa-se ainda que as PIN 21 (USP97-11.097), 35 (USP97-11.065), 50 (USP97-11.050) e 55 (USP97-11.080) possuem maior estabilidade e menor desvio que esta testemunha. Quando se observa as médias do CMI (Tabela 34) destaca-se a PIN 21 que se apresentou com o mesmo ciclo que a média das testemunhas (134 dias), com menor média de acamamento $(1,38)$, com maior valor agronômico $(3,60)$, ausência de sintomas de CHS $(1,00)$ e $\mathrm{PG}=3250 \mathrm{~kg} / \mathrm{ha}$, superando a média das progênies em $16 \% \mathrm{e}$ a das testemunhas em 15\%. A PIN 35 evidenciou-se por apresentar $P G=2797 \mathrm{~kg} / \mathrm{ha}$, igualando-se às médias de progênies e testemunhas; a PIN 50 apresentou média de CHS menor que a média das testemunhas $(1,19)$ e a PIN 55, com PG=2899 kg/ha, superou a média de progênies e testemunhas. As progênies de maior produtividade em ordem decrescente foram a PIN 21 (USP97-11.097), já destacada, com a terceira maior estabilidade deste CM; a PIN 13 (USP97-11.084) com a segunda maior PG do grupo, (14\% mais produtiva que a média das testemunhas) apresentou apenas estabilidade regular (13 colocada). As PIN 41 (USP97-11.076) e PIN 53 (USP97-11.072) não se destacaram quanto à estabilidade média, mas superaram a média das testemunhas em 13\%. A quarta maior produtividade ficou para as PIN 6 (USP97-11.062) e PIN 15 (USP97-11.090) com 12\% de superioridade em relação às testemunhas, superando 36 outras progênies em termos de estabilidade média. 
O limite adotado para o CMST foi o da testemunha IAC-11 $(\mathrm{Meco} \%=4,88)$; na Tabela 31 , observa-se que 14 progênies ( $70 \%$ do total) são mais estáveis que esta testemunha (Tabela 31). Com relação à testemunha mais estável IAC-8 $(\mathrm{Meco} \%=4,88)$, as PST 17 (USP97-11.119), 2 (USP97-11.110), 4 (USP97-11.112), 6 (USP97-11.114) e 14 (USP97-11.124) apresentaram resultados favoráveis tanto para Meco\% quanto para Seco\%. As PST 2, 4,6 e 14 apresentaram ótimos resultados na análise de médias (Tabela 35), com ciclo menor que o valor médio das testemunhas (141 dias), menor média de acamamento $(2,26)$, maior valor agronômico $(2,90)$, menor média de sintomas de CHS $(1,75)$ e PG superiores às médias de progênies $(\mathrm{Mp}=2817 \mathrm{~kg} / \mathrm{ha})$ e testemunhas $(\mathrm{Mt}=2649 \mathrm{~kg} / \mathrm{ha})$. As progênies mais produtivas em ordem decrescente foram a PST 9 (USP97-11.118) com $3119 \mathrm{~kg} /$ ha sendo $18 \%$ superior à PG média das testemunhas e superando apenas três progênies em estabilidade; a PST 18 (USP97-11.121) com 3102 $\mathrm{kg} / \mathrm{ha}$ ( $17 \%$ mais produtiva) destacando-se como a sexta melhor estabilidade do $\mathrm{CM}$; a PST 2 (USP97-11.110) com $2998 \mathrm{~kg} / \mathrm{ha}$ (13\% superior) e a terceira melhor estabilidade de todo o CM e a PST 17 (USP97-11.119) com superioridade de $9 \%$ em relação às testemunhas e a quarta melhor estabilidade.

\subsection{Correlações entre caracteres}

\subsubsection{Correlações fenotípicas de Pearson}

As estimativas dos coeficientes de correlação fenotípica entre os caracteres NDM, APM, Ac, VA, CHS e PG, obtidos com base na média de todos os ambientes encontram-se nas Tabelas 36, 37, 38 e 39, respectivamente para o CMP, CMSP, CMI e CMST. Esta análise foi realizada para progênies e testemunhas separadamente, dentro de cada CM, com o objetivo de facilitar a compreensão do comportamento dos genótipos.

As correlações obtidas entre NDM e APM (Tabelas 36 a 39) foram consistentes de um CM para o outro no grupo das progênies, porém variou muito para as testemunhas, o que indica, de acordo com Gomes (1995) que pode ter ocorrido uma forte influência ambiental, mascarando a expressão fenotípica da correlação entre 
caracteres. Os resultados apresentaram uma correlação positiva de baixa a média (entre 6 e $21,45 \%$ ) entre as progênies nos diferentes $\mathrm{CM}$, porém entre as testemunhas, esta variou entre correlações altas e negativas $(-62,91 \%$ no $\mathrm{CMI})$ até altas e positivas ( $48,98 \%$ no CMSP). As correlações positivas obtidas, que foram a maioria, concordam com aquelas encontradas por Pacova (1992), Santos(1994) e Gomes (1995), indicando que as plantas mais tardias tendem a ser mais altas, conforme esperado. Porém, Yokomizo (1999) detectou valores negativos (de baixos a altos) de correlação entre tais caracteres, comentando que provavelmente isto foi consequência de baixa estimativa de covariância entre os caracteres.

Os valores obtidos de correlação entre os caracteres NDM e Ac, e NDM e VA foram todos negativos (Tabelas 36 a 39), com exceção da correlação entre NDM e Ac para as testemunhas do CMSP onde esta foi de 22,95\% (Tabela 37). As magnitudes obtidas de correlações entre NDM e Ac para progênies foi de baixa a média (entre $0,31 \%$ a $-22,14 \%$ ) e para as testemunhas variou de $-36,66 \%$ (testemunhas do CMI) a $22,95 \%$ (testemunhas do CMSP). Com exceção deste último valor positivo obtido, todos os outros valores são considerados discrepantes, pois o observado no desenvolvimento das plantas é que quanto maior o ciclo, maior a tendência ao acamamento, pois elas tendem a crescer mais, e a altura geralmente é positivamente correlacionada com o acamamento. Valores positivos (de baixos a altos) para esta correlação foram detectados por Yokomizo (1999). As correlações negativas entre NDM e VA variaram de - 3,55\% a $-30,55 \%$ para progênies, e de $-11,80 \%$ a $-28,39 \%$ para testemunhas. Em condições de campo, plantas com maiores NDM crescem mais e, por isso, recebem maiores notas de VA, tornando a correlação positiva. Porém, a correlação entre NDM e APM não foi grande e em alguns casos foi negativa, podendo ter interferido na correlação esperada entre NDM e VA. Yokomizo (1999) também se deparou com valores negativos para tal correlação nas testemunhas utilizadas em seu trabalho; contrariamente Lopes (1996), Alliprandini (1996) e Pinheiro (1998) encontraram valores acima de 0,4.

Entre NDM e CHS correlações positivas foram observadas para o CMSP e CMI (Tabelas 37 e 38), para progênies e testemunhas; e valores negativos foram detectados no CMP e CMST (Tabelas 36 e 39), também para progênies e testemunhas. A 
magnitude das correlações foi de baixa a média, sendo que os valores observados nos CMSP e CMI concordam com o observado nas condições de campo, já que plantas mais tardias tendem a ser mais vulneráveis à incidência da doença por permanecerem mais tempo no campo, coincidindo com as condições climáticas ideais para a manifestação da doença. Ou seja, a ocorrência de escapes é esperada ser mais comum nas plantas precoces do que nas tardias. Os valores negativos de correlação entre NDM e CHS nos CMP $(-2,69 \%)$ e CMST $(-8,47 \%)$ são discrepantes, apesar de serem não-significativos.

Estimativas que não estavam sendo esperadas também foram observadas para a correlação entre NDM e PG (Tabelas 36 a 39). Valores negativos médios $(-10,19 \%$ a $46,88 \%$ ) foram detectados para esta correlação em todos os $\mathrm{CM}$, em progênies e testemunhas, exceção feita somente às testemunhas do CMSP, com $r=0,26 \%$. Estes resultados discordam da correlações positivas obtidas por vários outros autores (Anand \& Torrie, 1963; Pacova, 1992; Yokomizo, 1994; Gomes, 1995; Pinheiro, 1998), pois a tendência é de que quanto maior o ciclo da planta, mais ela cresce e, com isso, aumenta a área de internódios produtivos, logo a correlação esperada é positiva. Porém, Montenegro (1994) e Prado (1994) detectaram valores negativos para esta correlação, enquanto Yokomizo (1999) detectou valores altos e negativos em ambiente estressante (cultivo de outono-inverno e solo ácido). Isto sugere que a incidência da doença cancroda-haste, que é um fator de estresse diretamente ligado ao ciclo da cultura, pode ter influenciado esta correlação e mudado a sua tendência esperada. Outra causa pode ter sido a ocorrência de médias de NDM e PG muito próximas entre as progênies, refletindo numa baixa covariância estimada e alterando a correlação.

Entre APM e Ac, conforme comentado, existe uma forte associação positiva, que pôde ser demonstrada pelos valores de médios a altos obtidos na correlação entre eles, tanto para o grupo das progênies quanto para o de testemunhas (Tabelas 36 a 39). Tais valores oscilaram entre $26,56 \%$ e $68,33 \%$, e são bem explicados pelo fato de quanto maior a altura adquirida pela planta, maior a tendência a sofrer acamamento, principalmente por fatores ambientais, como fortes ventos incidentes. Valores semelhantes foram obtidos por Yokomizo $(1994,1999)$. 
Para APM e VA, valores negativos de magnitude baixa a mediana, foram observados em todos os CM (Tabelas 36 a 39) no grupo das progênies (valores entre $8,69 \% \mathrm{e}-15,91 \%$ ), enquanto que nas testemunhas valores negativos foram detectados somente no CMSP (Tabela 37). Os valores positivos das testemunhas do CMP (Tabela 36), CMI (Tabela 38) e CMST (Tabela 39), apesar da menor magnitude, concordam com alguns resultados de outros autores (Pacova, 1992; Gomes, 1995), ao passo que Freire Filho (1998) também detectou valores negativos para esta correlação. Geralmente, plantas com maior APM recebem notas maiores, porém, pelo fato de acamarem mais seu VA é reduzido. Isto pode ser comprovado na correlação entre Ac e VA que foi negativa e de mediana a alta (entre $-35,74 \%$ e $-71,02 \%$ ) para as progênies em todos os CM. Com exceção das testemunhas do CMP, as demais testemunhas também apresentaram valores negativos e medianos a altos $(-25,88 \%$ a $-62,79 \%)$ de correlação entre Ac e VA, comprovando tal afirmação. Estimativas semelhantes foram reportadas por Pacova (1992) e Yokomizo (1994, 1999).

Entre APM e CHS, valores de correlação negativos foram observados no CMI (Tabela 38) para progênies e testemunhas e no CMSP (Tabela 37) para testemunhas, sendo os demais valores positivos e de magnitude baixa a mediana. Os valores positivos observados já eram esperados, pois quanto maior a altura, maior o ciclo, e quanto maior o ciclo, maiores notas serão atribuídas ao CHS. Portanto, os demais valores negativos são considerados discrepantes. Entre Ac e CHS, estimativas positivas também são esperadas em consequência de correlações positivas entre Ac e APM e entre APM e CHS. Isto concorda com o observado em todos os $\mathrm{CM}$, sendo que o único valor negativo foi aquele obtido para as testemunhas do CMSP, porém de pequena magnitude.

Os valores obtidos entre VA e CHS, foram todos negativos e de magnitudes médias a altas $(-15,02$ a $-53,15 \%)$. Somente as testemunhas do CMP (Tabela 36) apresentaram valor baixo de correlação, porém também negativo $(-4,03 \%)$. Estes valores são coincidentes com o observado nos experimentos, onde a nota de VA é atribuída também de acordo com a reação do genótipo à doença cancro-da-haste, ou seja, genótipos mais suscetíveis à doença (notas maiores) recebem menores notas para VA, devido à depreciação visual do genótipo onde ocorre a doença. 
Para Ac e PG, observou-se correlações positivas para o CMP (Tabela 36), CMSP (Tabela 37) e CMI (Tabela 38), em progênies e testemunhas, sendo que nas PIN esta correlação esteve próxima de zero. Apenas nas PST observou-se valor negativo entre tais caracteres, conforme o esperado, pois quando as plantas acamam em campo, muitas vezes suas vagens tocam o solo, provocando apodrecimento das sementes e consequente quebra da produtividade. No entanto, Yokomizo (1999) e Saka (1996) também obtiveram valores positivos nas correlações entre os dois caracteres.

Entre os caracteres VA e PG, foram detectadas correlações positivas e altamente significativas para as progênies de todos os CM (Tabelas 36 a 39), com estimativas entre $28,08 \%$ e $32,51 \%$. Para as testemunhas do CMSP, um valor negativo baixo e nãosignificativo foi observado, porém para as testemunhas dos demais CM, assim como para as progênies, valores medianos (entre $22,13 \%$ e $38,37 \%$ ) altamente significativos foram detectados. A positiva associação entre VA e PG ocorre, pois as notas atribuídas a VA, apesar de subjetivas levam em conta todo o aspecto visual da planta, inclusive sua capacidade produtiva (número de vagens), então quanto maior o número de vagens presentes (maior PG), maior a nota de VA. Resultados similares, porém maiores, podem ser encontrados nos trabalhos de Gomes (1995), Lopes (1996), Alliprandini (1996) e Pinheiro (1998).

Para CHS e PG, conforme o esperado, observou-se valores negativos para a correlação fenotípica no grupo das progênies de todos os CM (Tabelas 36 a 39). Apesar de serem de magnitude pequena $(-12,53 \%$ a $13,86 \%)$, todos os valores foram significativos, exceto para as PPR que foi de baixa magnitude e não-significativo ($3,04 \%$ ). Para as testemunhas, valores negativos estiveram presentes no CMP, CMSP e CMI; e para as testemunhas do CMST a correlação entre tais caracteres esteve próxima de zero. Tais resultados concordam com as ocorrências experimentais, onde a alta incidência da doença, mostrou-se associada à menor PG. 


\subsubsection{Correlações genéticas}

As correlações genéticas foram obtidas para as progênies de cada CM estudado e, portanto, a discussão será feita entre os diferentes CM. Os caracteres e as combinações para o cálculo das correlações são os mesmos utilizados para a correlação fenotípica de Pearson, e os resultados das estimativas obtidas das correlações genéticas para os quatro CM encontram-se na Tabela 40.

De modo geral, as correlações genéticas foram superiores às fenotípicas e quase sempre apresentaram o mesmo sinal, tendência esta sendo concordante com os resultados obtidos por vários autores (Anand \& Torrie, 1963; Freire Filho, 1988; Pacova, 1992; Pinheiro, 1993; Montenegro, 1994; Santos, 1994; Gomes, 1995). De acordo com Gomes (1995), devido à expressão fenotípica da associação entre caracteres ser reduzida frente às variações ambientais, deve-se sempre procurar estimar ambas as correlações fenotípicas e genéticas, já que as expressões mais purificadas dos caracteres ocorrem nas correlações genéticas.

Ilustrando tal fato, as estimativas obtidas entre NDM e APM para os quatro CM (Tabela 40) foram duplicadas quando comparadas à correlação fenotípica obtida entre os mesmos caracteres. Os valores obtidos foram todos positivos e acima de 33\%, alcançando 59,91\% para as progênies do CMP. Correlações genéticas semelhantes, porém de maior magnitude entre estes caracteres foram obtidas por Pacova (1992), Gomes (1995) e Yokomizo (1999).

As correlações genéticas entre NDM e Ac (Tabela 40) foram positivas e medianas $(>20 \%$ ) conforme o esperado para o CMP e CMI, aproximadamente nulas para as progênies do CMSP e negativas de baixa magnitude para CMST (-3,95\%). Este valor negativo provavelmente ocorreu devido à presença de médias próximas entre as progênies para Ac e NDM no CMST, causando redução na covariância e alterando a correlação. As correlações positivas são semelhantes àquelas obtidas por Yokomizo (1999) e confirmam a tendência de aumento de acamamento nas plantas de maior ciclo.

Os valores obtidos entre NDM e VA (Tabela 40) ficaram divididos, em valores positivos para o CMP e CMST $(15,35 \%$ e $22,22 \%)$ e valores negativos para o CMI e 
CMSP $(-50,07 \%$ e $-47,11 \%)$. Conforme mencionado, uma maior tendência de correlação positiva entre tais caracteres existe, pois plantas de ciclo maior, crescem mais, recebendo maiores notas de VA. Estes resultados são concordantes com Pacova (1992) e Gomes (1995), por sua vez, Yokomizo (1999) encontrou alguns valores positivos e outros negativos para esta correlação.

Entre NDM e CHS (Tabela 40), correlações positivas já esperadas foram detectadas nas progênies do CMP $(37,52 \%)$, CMSP $(55,23 \%)$ e CMI $(42,18 \%)$. O único valor negativo foi do CMST $(-42,93 \%)$ confirmando o valor negativo observado na correlação fenotípica. Como as progênies do CMST apresentaram médias de NDM muito próximas (Tabela 35), tal fato pode ter alterado o sinal da correlação, tornando-a negativa. A maioria dos valores positivos obtidos confirmam a maior vulnerabilidade dos genótipos de maior ciclo à incidência da doença cancro-da-haste.

Valores negativos e altos entre NDM e PG (Tabela 40) estiveram presentes nas progênies do CMI $(-61,30 \%)$ e CMST $(-99,52 \%)$, enquanto a correlação genética entre os dois foi próxima a zero no CMSP e mediana e positiva para o CMP $(21,39 \%)$. O valor positivo obtido no CMP é concordante em magnitude e no sinal com os dados obtidos por Yokomizo (1999). Outras correlações genéticas positivas, porém de maior magnitude foram observadas por Pacova (1992) e Gomes (1995). Esta correlação indica que nem sempre as progênies mais tardias foram as mais produtivas, pois o maior ciclo pode ter levado a outras consequências, como aumento do acamamento ou da incidência do CHS, a exemplo do CMI, conforme observado nas correlações positivas entre NDM e Ac e entre NDM e CHS, que são fatores redutores da produtividade.

Conforme esperado, as correlações genéticas entre APM e Ac (Tabela 40) foram positivas e de média a alta magnitude, com valores de $82,46 \%$ (CMP), 44,67\% (CMSP), $61,12 \%$ (CMI ) e $43,62 \%$ (CMST), confirmando os valores positivos também obtidos nas correlações fenotípicas e as observações visuais feitas em condições de campo, de aumento do acamamento com a maior altura da planta, reforçando os valores obtidos por Yokomizo (1999).

Entre APM e VA (Tabela 40), valores negativos de correlação genética foram encontrados para as progênies do CMP, CMI e CMST. Apenas no CMST pôde-se 
verificar valores positivos para esta correlação $(12,14 \%)$, conforme esperado, já que plantas maiores possuem melhor aspecto visual e, assim, maiores notas de VA. Porém, como mencionado anteriormente, plantas maiores sofrem mais o efeito do acamamento e isto leva a notas menores de VA, conforme pode ser notado pelas medianas e altas correlações negativas obtidas entre Ac e VA para o CMP (-31,89\%), CMSP $(-53,52 \%)$, CMI $(-84,63 \%)$ e CMST $(-86,63 \%)$. Estes resultados seguem a mesma tendência observada nas correlações fenotípicas.

Valores negativos de correlação genotípica entre APM e CHS (Tabela 40) foram observados nas progênies dos quatro $\mathrm{CM}$ avaliados, sendo estes de pequena a média magnitudes $(-1,94 \%$ a $-34,96 \%)$. Tais valores, concordam com alguns valores negativos obtidos nas correlações fenotípicas e discordam daqueles positivos. O esperado é que esta correlação seja positiva, já que a altura esteve fortemente associada ao ciclo e o aumento deste esteve associado com o aumento da doença em quase todos os $\mathrm{CM}$, exceto no CMST. Sendo assim, valores negativos são considerados discrepantes. A correlação positiva esperada entre Ac e CHS foi observada para os CMSP (42,53\%), CMI $(25,93 \%)$ e CMST $(66,59 \%)$. Apenas no CMSP observou-se valores negativos $(-19,29 \%)$; trata-se de uma correlação indireta, pois como mencionado, está ligada às correlações positivas entre APM e CHS e entre APM e Ac, ocasionando assim a correlação positiva entre Ac e CHS. Tais resultados novamente concordam com a tendência observada nas correlações fenotípicas.

Outros resultados considerados discrepantes foram os obtidos entre APM e PG (Tabela 40), os quais foram negativos e de baixa magnitude no CMP $(-18,50 \%)$, próximo de zero no CMI, medianos no CMST $(-35,94 \%)$ e muito alto no CMSP $(<-$ $100 \%)$. Este último valor, matematicamente incorreto, de acordo com Gomez \& Gomez (1984) e Yokomizo (1999), ocorre devido aos dois caracteres apresentarem médias situadas numa faixa estreita de amplitude, o que pode reduzir muito a covariância e alterar o resultado final da correlação, mudando os sinais e ultrapassando o limite de \pm $100 \%$. Sendo assim, tais resultados de correlação genética entre APM e PG discordam daqueles obtidos por Pacova (1992), Gomes (1995) e Yokomizo (1999), onde foram encontrados valores altos e positivos. 
Entre Ac e PG (Tabela 40), observou-se correlações genéticas de valores negativos para o CMP (-17,98\%), CMI (-14,19\%) e nos CMSP e CMST com valores < $100 \%$. Valor negativo semelhante foi observado somente nas PST nas correlações fenotípicas, confirmando o que era esperado, de acordo com as condições de campo observadas, ou seja, quanto maior o acamamento, menor a produtividade devido às perdas de vagens que possam tocar o solo. Como no caso anterior, correlações menores que $-100 \%$ foram observadas para estes caracteres, novamente no CMSP e também no CMST, provavelmente pelas mesmas razões já citadas.

Os valores de correlação genética obtidos entre VA e PG (Tabela 40), foram de 57,32\% (CMP), 81,97\% (CMSP), 47,34\% (CMI) e <-100\% (CMST). Conforme observado, apenas o CMST não apresentou a correlação positiva existente entre estes dois caracteres, pois analisando-se as tabelas de médias (Tabelas 32 a 35) nota-se que o CMST possui médias de VA menores que os outros CM e médias de Ac um pouco maiores, reduzindo as notas de VA e fazendo surgir esta correlação negativa. Para os demais CM, a correlação entre VA e PG foi positiva e de mediana a alta, concordando com os valores obtidos de correlação fenotípica e com os valores obtidos por Pacova (1992), Gomes (1995) e Yokomizo (1999). Isto também comprova o fato de que a maior capacidade produtiva atribui maiores notas ao VA.

Entre VA e CHS (Tabela 40) foram obtidos valores negativos em todos os CM, sendo estes de magnitude média ( $-32,96 \%$ no CMP) a muito alta (<- $-100 \%$ no CMSP). Isto é compreensivel, já que a nota de VA considera o estado fitossanitário da planta, sendo atribuídas maiores notas de VA a genótipos mais sadios (menores notas de CHS). Estes valores são coincidentes com todas as estimativas obtidas de correlação fenotípica entre estes dois caracteres.

Para PG e CHS (Tabela 40), também foram obtidas estimativas negativas de correlação genética nos CMP $(-59,80 \%)$ e CMI $(-21,44 \%)$, porém também foram obtidos valores positivos nos CMSP $(64,03 \%)$ e CMST $(>100 \%)$. As correlações positivas são consideradas discrepantes, já que a incidência da doença cancro-da-haste causa graves prejuízos ao potencial produtivo dos genótipos afetados. Os valores negativos 
concordam com as estimativas de correlação fenotípica obtidas, sendo que apenas as testemunhas do CMST apresentaram valor positivo. 


\section{CONCLUSÕES}

Os resultados obtidos nos seis ambientes avaliados, permitem as seguintes conclusões:

a) A variabilidade genética entre progênies (cruzamentos óctuplos) foi detectada em todos os caracteres e ciclos de maturação (CM), com maior destaque para o ciclo intermediário. Em todos os $\mathrm{CM}$, as progênies (cruzamentos óctuplos) apresentaram maior variabilidade que as testemunhas (cruzamentos biparentais).

b) Os efeitos ambientais foram menores nos caracteres valor agronômico (VA) e sintomas de cancro-da-haste (CHS). A capacidade relativa dos locais em discriminar as progênies variou com o ano agrícola, com eficiência decrescente para ESALQ, Anhembi e Areão. O aumento no número de anos agrícolas de avaliação, melhorou a discriminação das progênies.

c) A interação genótipo $\times$ local $(G \times$ L) foi mais pronunciada nos caracteres produtividade de grãos (PG) e acamamento (Ac) em todos os ciclos. Já os caracteres altura da planta na maturidade (APM) e CHS manifestaram as menores magnitudes de $\mathrm{G} \times \mathrm{L}$. A interação genótipo $\times$ ano ( $\mathrm{G} \times \mathrm{A}$ ) também foi significativa em 20 das 24 combinações obtidas entre seis caracteres e quatro CM. A interação tripla (genótipo $\mathrm{x}$ local $\mathrm{x}$ ano) apresentou-se mais significativa para as progennies do que para as testemunhas nos ciclos precoce, semi-precoce e intermediário, mas foi nãosignificativa no ciclo semi-tardio.

d) A magnitude da estabilidade fenotípica nos seis ambientes variou entre as progênies. Ocorreram progênies (cruzamentos óctuplos) com estabilidade superior ou igual a 
das testemunhas (cruzamentos biparentais) em 22 das 24 combinações obtidas entre seis caracteres e quatro $\mathrm{CM}$.

e) A seleção para APM e VA deve também considerar Ac. Além disso, as progênies com maior VA tendem a ser mais produtivas. Apesar das tendências de correlações positivas NDM $\times$ PG e NDM x CHS, existiram progênies superiores em PG e sem sintomas de CHS em todos os CM.

f) No ciclo precoce, as melhores progênies tiveram PG semelhante a das testemunhas e mostraram baixos sintomas de CHS ou ausência dos mesmos. No ciclo intermediário, ocorreram progênies com PG superiores a das testemunhas e com ausência de sintomas de CHS. Nos ciclos semi-precoces e semi-tardios, detectou-se progênies com PG superiores e baixos sintomas de CHS.

g) As progênies que mais se destacaram para estabilidade fenotípica e desempenho agronômico dos seis caracteres foram: USP97-11.004 (precoce), USP97-11.030 (semi-precoce), USP97-11.097 (intermediária) e USP97-11.110 (semi-tardia). 


\section{REFERÊNCIAS BIBLIOGRÁFICAS}

ABLETT, G.R.; BUZZELL, R.I.; BEVERSDORF, W.D.; ALLEN, O.B. Comparative stability of 40 indeterminate and semideterminate soybean lines. Crop Science, v.34, p.347-351, 1994.

ADEGOKE, A.O.; FREY, K.J. Grain yield response and stability for oat lines with low-, medium- and high-yielding ability. Euphytica, v.36, n.1, p.121-127, 1987.

ALLARD, R.W. Princípios do melhoramento genético das plantas. São Paulo: Edgard Blucher, 1971. 381p.

ALLARD, R.W.; BRADSHAW, A.D. Implications of genotype-environmental interactions in applied plant breeding . Crop Science, v.4, n.5, p.503-508, 1964.

ALLIPRANDINI, L. F. Potencialidade de cruzamentos quádruplos de soja com ênfase na produtividade de grãos. Piracicaba, 1996. 174p. Tese (Doutorado) - Escola Superior de Agricultura "Luiz de Queiroz", Universidade de São Paulo.

ALLIPRANDINI, L.F;; TOLEDO, J.F.F.; FONSECA Jr, N.; ALMEIDA, L.A; KIIHL, R.A.S. Efeitos da interação genótipo $\mathrm{x}$ ambiente sobre a produtividade da soja no estado do Paraná. Pesquisa Agropecuária. Brasileira, v.29, n.9, p.1433$1444,1994$. 
ALMEIDA, L.A. de; KIIHL, R.A. Melhoramento da soja no Brasil - desafios e perspectivas. In: CÂMARA, G.M. Soja: tecnologia da produção. Piracicaba: Publique, 1998. p.40-54.

ANAND, S.C.; TORRIE, J.H. Heritability of yield and other traits and interrelationships among traits in $F_{3}$ and $F_{4}$ generation of three soybean crosses. Crop Science, v.3, n.6, p.508-511, 1963.

ANNICCHIARICO, P. Additive main effects and multiplicative interaction (AMMI) analysis of genotype-location interaction in variety trials repeated over years. Theoretical Applied Genetics, v.94, p. 1072-1077, 1997.

ARIAS, E.R.A. Adaptabilidade e estabilidade das cultivares de milho avaliadas no estado de Mato Grosso do Sul e avanço genético obtido no período de 1986/87 a 1993/94. Lavras, 1996. 118p. Tese (Doutorado) - Universidade Federal de Lavras.

AZEVEDO FILHO, J. A. de. Potencialidade de linhagens experimentais de soja em solos contrastantes na saturação de alumínio. Piracicaba, 1997. 139p. Tese (Doutorado) - Escola Superior de Agricultura "Luiz de Queiroz", Universidade de São Paulo.

BAYS, I.A. Heritability and association of several quantitative characters in segregating populations of soybeans (Glycine $\max ($ L.) Merrill). Mississipi, 1975. 91p. Thesis Mississipi State University.

BERNARD, R.L. Two major genes for flowering and maturity in soybeans. Crop Science, v.11, n.2, p.242-244, 1971.

BHATNAGAR, P.S.; KARMAKAR, P.G. Stability of soybean varieties across diverse locations in India. Soybean Genetics Newsletter, v.20, p.59-62, 1993. 
BONATO, E.R.; VELLO, N. A. Aspectos genéticos do tempo para o florescimento em variantes naturais de soja. Pesquisa Agropecuária Brasileira, v. 34, n. 6, p. 989993,1999 a .

BONATO, E.R.; VELLO, N. $\mathrm{E}_{6}$ a dominant gene conditioning early flowering and maturity in soybeans. Genetics and Molecular Biology, v. 22, n. 2, p. 229-232, $1999 b$.

BRIM, C.A. Quantitative genetics and breeding. In: CALDWELL, B.E. (Ed.) Soybeans: improvement, production and uses. Madison: American Society of Agronomy, 1973. cap.5, p.155-186.

BRIM, C. A. ; BURTON, J.W. Recurrent selection in soybeans. II. Selection for increased percent protein in seeds. Crop Science, v.19, p.494-498, 1979.

BRIM, C.A. ; COCKERHAM, C.C. Inheritance of quantitative characters in soybeans. Crop Science, v.1, n.3, p.187-190, 1961.

BRIM, C.A.; STUBER, C.W. Application of genetic male sterility to recurrent selection schemes in soybeans. Crop Science, v.13, n.5, p.528-530, Sept./Oct. 1973.

BURTON, J.W. Quantitative genetics: results relevant to soybean breeding. In: WILCOX, J.R.(Ed.). Soybeans: improvement, production and uses. 2.ed. Madison: American Society of Agronomy, 1987. cap.6, p.211-247.

BURTON, J.W. Soyabean (Glycine max (L.) Merr.). Field Crops Research, v.53, p.171-186, 1997.

BURTON, J.W.; BRIM, C.A. Recurrent selection in soybeans. III. Selection for increased percent oil in seeds. Crop Science, v.21, p. 31-34, 1981. 
BURTON, J.W.; KOINANGE, E.M.K.; BRIM, C.A. Recurrent selfed progeny selection for yield in soybean using genetic male sterility. Crop Science, v.30, p.1222-1226, 1990.

BUZZELL, R.I. Inheritance of a soybean flowering response to fluorescent daylenght conditions. Canadian Journal of Genetics Citology, v.13, n.4, p.703-707, 1971.

BUZZELL, R.I. ; VOLDENG, H.D. Inheritance of insensitivy to long daylenghts. Soybean Genetics Newsletter, v.7, p.26-29. 1980.

CAMACHO, M.L.H. Varianzas geneticas y heredabilidade de caracteristicas vegetativas y reprodutivas da soya Glycine max (L.) Merrill. Acta Agronomica, v.21, n. 4, p. $145-152,1971$.

CARVALHO, F.I.F.; FEDERIZZI, L.C.; NODARI, R.O.; STORCK, L. Comparison among stability models in evaluating genotypes. Revista Brasileira de Genética, v.6, n.4, p.667-691, 1983.

CAVINESS, C. E. ; PRONGSIRIVATHANA, C. Inheritance and association of plant height and its components in soybean cross. Crop Science, v.8, n.2, p.221-224. 1968.

CHAUHAN, V.S. ; SINGH, B.B. Genetic variability and heritability in soybean. Indian Journal of Agricultural Science, v.54, n.4, p.273-276, 1984.

COBER, E.R.; FRÉGEAU-REID, J.A.; PIETRZAK, L.N.; McELROY, A.R.; VOLDENG, H.D. Genotype and environmental effects on natto soybean quality traits. Crop Science, v.37, p.1151-1154. 1997. 
COMSTOCK, R.E.; MOLL, R.H. Genotype-environment interactions. In: HANSON, W.D. ; ROBINSON, H.F. (Ed.) Statistical Genetics and Plant Breeding. Washington: National Academy Science Natural Research. Council, 1963. p.164-196. (Publication, 982).

COSTA, J.A. Cultura da Soja. Porto Alegre: Evangraf, 1996. 233p.

CROSSA, J.; GAUCH JR., H.G.; ZOBEL, R.W. Additive main effects and multiplicative interaction analysis of two international maize cultivar trials. Crop Science, v.30, n.3, p.493-500, 1990.

CRUZ, C.D. Programa GENES : aplicativo computacional em genética e estatística. Viçosa, Imprensa Universitária. 1997. 442p.

CRUZ, C.D.; CASTOLDI, F.L. Decomposição da interação genótipo $\mathrm{x}$ ambientes em partes simples e complexa. Revista Ceres, v.38, n.219, p.422-430, 1991.

CRUZ, C.D.; REGAZZI, A.J. Modelos biométricos aplicados ao melhoramento genético. Viçosa: UFV, 1994. 390p.

CRUZ, C.D.; TORRES, R.A. A.; VENCOVSKY, R. An alternative approach to the stability analysis proposed by Silva and Barreto. Revista Brasileira de Genética, v. 12, n. 2, p. $567-580,1989$.

DASHIEL, K.E.; ARIYO, O.J.; BELLO, L.; OJO, K. Genotype $\mathrm{x}$ environment interaction and simultaneous selection for high yield and stability in soybeans (Glycine max (L.) Merrill). Annals of Applied Biology, v.124, p.133-139, 1994. 
DEKA, S.D.; TALUKDAR, P. Stability behaviour of some soybean (Glycine max (L.) Merrill) genotypes under environmental variability. Indian Journal of Genetics, v. 54, n. 1, p. 36-39, 1997.

DESTRO, D. Capacidade de combinação de genótipos de soja (Glycine max (L.) Merrill) apropriados para o consumo humano. Piracicaba, 1991. 158p.Tese (Doutorado) - Escola Superior de Agricultura "Luiz de Queiroz", Universidade de São Paulo.

DOLAN, D.J.; STUTHMAN, D.D.; KOLB, F.L.; HEWINGS, A.D. Multiple trait selection in a recurrent selection population in oat (Avena sativa L.). Crop Science, v.36, p.1207-1211, 1996.

DUARTE, J.B. Estudo da adaptabilidade e estabilidade fenotípica em cultivares de feijão mulatinho (Phaseolus vulgaris L.). Goiânia, 1988, 155p. Dissertação (Mestrado) - Escola de Agronomia, Universidade Federal de Goiás.

DUARTE, J.B. ; ZIMMERMANN, M.J.O. Correlation among yield stability parameters in common bean. Crop Science, v.35, n.3, p.905-912, 1995.

DUARTE, J.B.; ROLIM, R.B.; OLIVEIRA, P.M.F.; SOUZA, J.R. Adaptabilidade e estabilidade de rendimento de genótipos de soja (Glycine max (L.) Merril), nas condições de Goiás e Distrito Federal. Anais Escola de Agronomia e Veterinária, v.24, n.1, p.90-109, 1994.

EBERHART, S.A.; RUSSEL, W.A. Stability parameters for comparing varieties. Crop Science, v.6, n.1, p.36-40, 1966

FALCONER, D.S. Introdução à genética quantitativa. Viçosa: Imprensa Universitária da UFV, 1987. 279p. 
FARIAS NETO, J.T. Potencialidade de progênies $F_{4: 3}$ e $F_{5: 3}$ derivadas de cruzamentos em cadeia para produtividade de óleo em soja. Piracicaba, 1995. 150p. Tese (Doutorado) - Escola Superior de Agricultura "Luiz de Queiroz", Universidade de São Paulo.

FATMI, A.; WAGNER, D.B.; PFEIFFER, T.W. Intermating schemes used to synthesize a population are equal in genetic consequences. Crop Science, v.32, n.1, p.89-94, 1992.

FEHR, W. R. Principles of cultivar development. New York: Macmillan, 1987a. cap.12, p.137-155: Population formation by hybridization.

FEHR, W. R. Principles of cultivar development. New York: Macmillan, 1987b. cap. 15, p.172-192: Recurrent selection.

FINLAY, K.W.; WILKINSON, G.N. The analysis of adaptation in a plant-breeding programme. Australian Journal of Agricultural Research, v.14, p.742-754, 1963.

FNP Consultoria ; Comércio. Agrianual 99: anuário da agricultura brasileira. São Paulo, 1999. p.448-483: Soja.

FOX, P.N.; CROSSA, J.; ROMAGOSA, I. Multi-environment testing and genotype $\mathrm{x}$ environment interaction.In: KEMPTON, R.A.; FOX, P.N.(Ed.) Statistical methods for plant variety evaluation. New York: Chapman and Hall, 1997. cap.8, p.117-138.

FREIRE FILHO, F.R. Análise genética de um dialelo entre genótipos precoces de soja (Glycine $\max ($ L.) Merrill). Piracicaba, 1988. 224p. Tese (Doutorado) - Escola Superior de Agricultura "Luiz de Queiroz", Universidade de São Paulo. 
FUCHS, A.; LEIPZIG, G.D.R.; PEREZ PONCE, J. Methods for estimating the yield stability-variety trials with sugar cane. Beitrage zur Tropischen Landwirtschaft und Veterinarmedizin, v.17, n.4, p.351-359, 1979.

GALVÃO, E.R. Adaptabilidade e estabilidade de comportamento de nove genótipos de soja (Glycine max (L.) Merrill) em Ponta Porã, Mato Grosso do Sul. Viçosa, 1994. 52p. Tese (Mestrado) - Universidade Federal de Viçosa.

GATES, C.E.; WEBER, C.R.; HORNER, T.W. A linkage study of quantitative characters in a soybean cross. Agronomy Journal, v.52, n.1, p.45-49, 1960.

GIZLICE, Z; CARTER Jr., T.E.; BURTON, J.W. Genetic base for north american public soybean cultivars released between 1947 and 1988. Crop Science, v.34, p.1143-1151, 1994.

GOLDRINGER, I.;BRABANT, P. Sélection récurrent chez les autogames pour l'amélioration des variétés lignées pures: une revue bibliographique. II. Agronomie, v. 13, p.561-577, 1993.

GOLDRINGER, I.; BRABANT, P.; GALLAIS, A. Theoretical comparison of recurrent selection methods for the improvement of self-pollinated crops. Crop Science, v.36, p.1171-1180, 1996.

GOMES, F. P. Curso de estatística experimental. 13. ed. São Paulo: Nobel, 1990. $468 \mathrm{p}$.

GOMES, F. P.. In: GOMES, F.P.(Ed.). Curso de estatística experimental. 14 ed Piracicaba: Nobel, 1991., cap.8, p.168-197. Análise de grupos de experimentos 
GOMES, R.L.F. Análise genética de progênies $F_{6}$ e $F_{7: 6}$ de soja obtidas de cruzamentos dialélicos. Piracicaba, 1995. 140p.Tese (Doutorado) - Escola Superior de Agricultura "Luiz de Queiroz", Universidade de São Paulo.

GOMEZ, K. A. ; GOMEZ, A.A. Statistical procedures for agricultural research. New York: John Wiley, 1984. cap.9, p.357-423: Regression and correlation analysis

HAMAWAKI, O.T. Potencial de progênies selecionadas em cruzamentos óctuplos de soja com ênfase na produtividade de óleo. Piracicaba, 1998. 128p.Tese (Doutorado) Escola Superior de Agricultura "Luiz de Queiroz", Universidade de São Paulo.

HANSON, W. D. Phenotypic recurrent selection for modified reproductive period in soybean. Crop Science, v.32, p.968-972, 1992.

HANSON, W. D. ; WEBER, C. R. Resolution of genetic variability in self-pollinated species with an application to the soybean. Genetics, v.46, n.11, p.1425-1434, 1961.

HANSON, W. D. ; WEBER, C. R. Analysis of genetic variability from generations of plant progeny lines in soybeans. Crop Science, v.2, n.1, p.63-67, 1962.

HANSON, W.D.; PROBST, A.H.; CALDWELL, B.E. Evaluation of a population of soybean genotypes with implications for improving self-pollinated crops. Crop Science, v. 7, n.2, p.99-103, 1967.

HARTLEY, H.O. The use of range in analysis of variance. Biometrika, v.37, p.271$280,1950$.

HIROMOTO, D.M.; VELLO, N.A. The genetic base of Brazilian soybean (Glycine max (L.) Merrill) cultivars. Revista Brasileira de Genética, v.9, n.2, p.295-306, 1986. 
HIROMOTO, D.M. Seleção de genótipos de soja para performance agronômica e resistência a Heterodera glycines Ichinohe e Diaporthe phaseolorum f.sp.meridionalis Morgan - Jones. Piracicaba, 1996. 84p. Tese (Doutorado) - Escola Superior de Agricultura "Luiz de Queiroz", Universidade de São Paulo.

HYMOWITZ, T.; SINGH, R.J.; KOLLIPARA, K.P. Biosystematics of the genus Glycine, 1996. Soybean Genetics Newsletter, v.24, p.119-120, May 1997.

ININDA, J.; FEHR, W.R.; CIANZIO, S.R.; SCHNEBLY, S.R. Genetic gain in soybean populations with different percentages of plant introduction parentage. Crop Science, v.36, p.1470-1472, 1996.

IVORY, D.A.; KAEWMEECHAI, S.; DELACY, I.H.; BASFORD, K.E. Analysis of the environmental component of genotype $\mathrm{x}$ environment interaction in crop adaptation evaluation. Field Crops Research, v.28, p.71-84. 1991.

KANG, M.S. ; MILLER, J.D. Genotype x environment interactions for cane and sugar yield and their implications in sugarcane breeding. Crop Science, v.24, p.435-440, 1984.

KANG, M.S.; HARVILLE, B.G.; GORMAN, D.P. Contribution of weather variables to genotype $\mathrm{x}$ environment interaction in soybean. Field Crops Research, v.21, p.297$300,1989$.

KEMPTHORNE, O. An introduction to genetics statistics. 3.ed. Ames: Iowa State University Press, 1973. 545p.

KENWORTHY , W.J. ; BRIM, C.A. Recurrent selection for yield in soybeans : I. Seed yield. Crop Science, v.19, n.3, p.315-318, May/June 1979. 
KIIHL, R.A.S. ; ALMEIDA, L.A. Situação atual e perspectivas do melhoramento genético da soja no Brasil. In: SIMPÓSIO SOBRE A CULTURA E PRODUTIVIDADE DA SOJA, 1., Piracicaba, 1991. Anais:. Piracicaba, FEALQ, 1992. p.38-40.

LAÍNEZ-MEJÍA, J.R. Interação genótipo $\mathrm{x}$ ambientes em progênies de soja derivadas de cruzamentos em cadeia com ênfase na produtividade de óleo. Piracicaba, 1996. 144p. Tese (Doutorado) - Escola Superior de Agricultura "Luiz de Queiroz", Universidade de São Paulo.

LEFFEL, R.C. ; HANSON, W.D. Early generation testing of diallel crosses of soybeans. Crop Science, v.1, p.169-174, 1961.

LOPES, A.C.A. Potencialidade de cruzamentos óctuplos de soja com ênfase na produtividade de grãos. Piracicaba, 1996. 102p. Dissertação (Mestrado) - Escola Superior de Agricultura "Luiz de Queiroz", Universidade de São Paulo.

MAESTRI, D.M.; LABUCKAS, D.O; MERILES, J.M; LAMARQUE, A.L.; ZYGADLO, J.A.; GUZMÁN, C.A. Seed composition of soybean cultivars evaluated in different environmental regions. Journal of Science Food Agricultural, v.77, p.494-498. 1998.

MALAVOLTA, E.; VITTI, G.C.; OLIVEIRA, S.A. de. Avaliação do estado nutricional das plantas: princípios e aplicações. Piracicaba: Potafos, 1989. 201p.

MARIOTTI, J.A.; OYARZABAL, E.S.; OSA, J.M; BULACIO, A.N.R.; ALMADA, G.H. Analisis de estabilidad y adaptabilidad de genótipos de caña de azucar. I. Interacciones dentro de una localidad experimental. Revista Agronomica del Noroeste Argentino, v.13, n.1/4, p.105-127, 1976. 
MARSHALL, D.R. ; BROWN, A.H.D. Stability of performance of mixtures and multilines. Euphytica, v.22, n.4, p.405-412, 1973.

Mc BLAIN, B.A. ; BERNARD, R.L. A new gene affecting the time of flowering and maturity in soybeans. The Journal of Heredity, v.78, n.3, p.160-162, 1987.

MEBRAHTU, T. ; ELMI, A. Stability analysis of vegetable soybean. Soybean Genetics Newsletter, v.24, p.214-215. 1997.

MONTENEGRO, E.E. Estimativas de parâmetros genéticos, no verão e no inverno, em cruzamentos entre cultivares de soja (Glycine max (L.) Merrill), divergentes quanto à juvenilidade. Viçosa, 1994. 97p. Tese (Mestrado) - Universidade Federal de Viçosa.

MONTEVERDE, E. Correlaciones fenotipicas y genotipicas entre rendimiento, proteina, aceite y otras caracteristicas en soya (Glycine max). Revista de la Facultad de Agronomia, Maracay, v.13, n.1/4, p. 183-214, 1984.

NASS, L.L. Potencialidade de genótipos de soja (Glycine max (L.) Merrill) para cultivo de inverno avaliada por cruzamentos dialélicos. Piracicaba, 1989.112p. Dissertação (Mestrado) - Escola Superior de Agricultura "Luiz de Queiroz", Universidade de São Paulo.

OLIVEIRA, A.C. Comparação de alguns métodos de determinação da estabilidade em plantas cultivadas. Brasília, 1976. 64p. Dissertação (Mestrado) - Universidade de Brasília.

PACOVA, B.E.V. Análise genética de progênies segregantes de soja apropriada para o consumo humano. Piracicaba, 1992. 217p. Tese (Doutorado) - Escola Superior de Agricultura "Luiz de Queiroz", Universidade de São Paulo. 
PARENTE, R.C.P. Aspectos da análise de residuos. Piracicaba, 1984. 139p. Dissertação (Mestrado) - Escola Superior de Agricultura "Luiz de Queiroz", Universidade de São Paulo.

PAZDERNIK, D.L.; HARDMAN, L.L.; ORF, J.H. Agronomic performance and stability of soybean varieties grown in three maturity zones of Minnesota. Journal Production Agriculture, v.10, p.425-430. 1997.

PRADO. L.C. Perspectivas para o melhoramento de linhagens homozigóticas de soja, com ênfase em produção de grãos e teor de proteína. Piracicaba, 1994. 128p. Dissertação (Mestrado) - Escola Superior de Agricultura "Luiz de Queiroz", Universidade de São Paulo.

PEREIRA, D.G.; SEDIYAMA, T.; CRUZ, C.D.; GOMES, J.L.L.; TEIXEIRA, R.C. Análise de estabilidade fenotípica de cultivares de soja (Glycine max (L.) Merrill) em relação a diferentes isolados de Diaphorte phaseolorum f.sp.meridionalis. Revista Ceres, v.43, n.250, 743-754, 1996.

PEREIRA, D.G.; SEDIYAMA, T.; SEDIYAMA, C.S.; CASALI, V.W.D.; SILVA, R.F. Herdabilidade de caracteres agronômicos de genótipos de soja, descendentes de dois processos de seleção. In: SEMINÁRIO DE PESQUISA DA SOJA , 3., Campinas, 1984. Anais. Londrina, EMBRAPA,CNPSo, 1984. p.521-527.

PFEIFFER, T.W.; GRABAU, L.J.; ORF, J.H. Early maturity soybean production system: Genotype x Environment interaction between regions of adaptation. Crop Science, v.35; p.108-112. 1995.

PINHEIRO, J.B. Dialelo parcial entre parentais de soja resistentes e suscetíveis a insetos. Piracicaba, 1993. 143p. Dissertação (Mestrado) - Escola Superior de Agricultura "Luiz de Queiroz", Universidade de São Paulo. 
PINHEIRO, J.B. Seleção para caracteres agronômicos, em diferentes épocas de cultivo, de populações de soja com resistência a insetos. Piracicaba, 1998. 143p. Tese (Doutorado) - Escola Superior de Agricultura "Luiz de Queiroz", Universidade de São Paulo.

PLAISTED, R.L. ; PETERSON, L.C. A technique for evaluating the ability of selections to yield consistently in different locations or seasons. American Potato Journal, v.36, p.381-385, 1959.

POMERANKE, G.J.; STUTHMAN, D.D. Recurrent selection for increased grain yield in oat. Crop Science, v.32, p.1184-1187. 1992.

RAIZER, A.J. Interações genótipos $\mathrm{x}$ ambientes e estabilidade fenotípica em cana-deaçúcar no estado de São Paulo. Piracicaba, 1998. 104p. Dissertação (Mestrado)Escola Superior de Agricultura "Luiz de Queiroz", Universidade de São Paulo.

RAMALHO, M.A.P.; SANTOS, J.B.; ZIMMERMANN, M.J. de O. Genética quantitativa em plantas autógamas : aplicações ao melhoramento do feijoeiro. Goiânia: UFG, 1993.271p.

RANALLI, P. Phenotypic recurrent selection in common bean (Phaseolus vulgaris L.) based on performance of $S_{2}$ progenies. Euphytica, v.87, p.127-132, 1996.

RANGEL, P.H.N.; GUIMARÃES, E.P.; NEVES, P.C.F. Base genética das cultivares de arroz (Oriza sativa L.) irrigado no Brasil. Pesquisa Agropecuária Brasileira, v.31, n. 5, p.349-357, 1996.

RASMUSSON, D.C.; PHILLIPS, R.L. Plant breeding progress and genetic diversity from De Novo variation and elevated epistasis. Crop Science, v.37, p.303-310, 1997. 
RAUT, V.M.; TAWARE, S.P.; HALVANKAR, G.B.; PATIL, V.P. Stability analysis for oil and yield in soybean. Soybean Genetics Newsletter, v.24, p.92-95, 1997.

ROCHA, M.M. Interação genótipos $\mathrm{x}$ locais em linhagens experimentais de soja com diferentes ciclos de maturação. Piracicaba, 1998. 98p. Dissertação (Mestrado)Escola Superior de Agricultura "Luiz de Queiroz", Universidade de São Paulo.

ROGNLI, O.A. Genetic variation in artic populations of timothy (Phleum pratense L.) II. Phenotypic stability of seed production. Hereditas, v. 107, n. 1, p.75-94, 1987.

ROSE, I.A. Evaluation of soybean breeding lines by examining their responses to sowing date and row spacing. Australian Journal of Experimental Agriculture, v. 27, n. 5, p. $721-726,1987$.

ROSE, J.L.; BUTLER, D. G.; RYLEY, M. J. Yield improvement in soybeans using recurrent selection. Australian. Journal of Agricultural Research. v.43, p.135144.1992.

RUBIN, S.A.L.; SANTOS, O.S. Progresso no melhoramento genético da soja no estado do Rio Grande do Sul : I. Rendimento de grãos. Pesquisa Agropecuária Gaúcha , v. 2, n.2, p.139-147, 1996.

SAKA, K.; SHIPE, E.R.; WALLACE, S.U. Relationships among plant characteres in soybean with different seed size. Soybean Genetics Newsletter, v.23, p.225-229, 1996.

SAKIYAMA, N.S.; SEDIYAMA, T.; SEDIYAMA, C.S.; REIS, M.S. Interação genótipo $\mathrm{x}$ ambiente e seus efeitos na escolha de localidades para avaliação de linhagens de soja [Glycine $\max$ (L.) Merril]. Revista Ceres, v.35, n.201, p.486-493, 1988. 
SANTOS, C.A.F. Análise de trilha e estimativas de parâmetros genéticos em progênies $\mathrm{F}_{6}$ de um cruzamento de soja (Glycine max (L.) Merrill). Viçosa, 1994. 71p. Tese (Mestrado) - Universidade Federal de Viçosa.

SÃO PAULO (Estado). Secretaria de Agricultura e Abastecimento. Regimento interno do sistema de avaliação e recomendação de cultivares de soja para o Estado de São Paulo. São Paulo, 1990. 15p.

SAS, INSTITUTE. SAS user's guide: statistic; version 6.11. Cary, 1996. 956p.

SCHNEBLY, S.R.; FEHR, W.R. Effect of years and planting dates on fatty acid composition of soybean genotypes. Crop Science, v.33, p.716-719, 1993.

SCOTT, R.A.; CHAMPOUX, M.; SCHAPAUGH Jr., W.T. Influence of environmental productivity levels and yield stability on selection strategies in soybean. Euphytica, v.78, p.115-122, 1994.

SHUKLA, G.K. Some statistical aspects of partitioning genotype-environmental components of variability. Heredity, v.29, p.237-245, 1972.

SILVA, J.G.C. ; BARRETO, J.N. Aplicação da regressão linear segmentada em estudos da interação genótipo $x$ ambiente. In: SIMPÓSIO DE ESTATÍSTICA APLICADA À EXPERIMENTAÇÃO AGRONÔMICA, 1., Piracicaba, 1985. Anais. Campinas: Fundação Cargill, 1985. p.49-50.

SILVA, R.G.da. Métodos de genética quantitativa aplicados ao melhoramento animal. Ribeirão Preto: 1982. 162p.

SINGH, T.P.; SINGH, K.B.; BRAR, J.S. Diallel analysis in soybean. Indian Journal of Genetic \& Plant Breeding, v.34, n.3, p.427-432, Nov.1974. 
SIVEIRO, A., MENTEN, J. O.;VELLO, N.A. Herança da resistência da soja a Diaphorte phaseolorum f. sp. Meridionalis. Summa Phytopathologica, v. 23, n. 2, p. 139-142, 1997.

SNELLER, C. H.; DOMBEK, D. Comparing soybean cultivar ranking and selection for yield with AMMI and full-data performance estimates. Crop Science, v.35, p.1536$1541,1995$.

SNELLER, C.H.; KILGORE-NORQUEST, L.; DOMBEK, D. Repeatability of yield stability statistics in soybean. Crop Science v.37, p.383-390, 1997.

SOLDINI, D.O. Interação genótipos x locais e correlações entre caracteres com ênfase na produtividade de óleo em soja. Piracicaba, 1993. 136p. Dissertação (Mestrado)Escola Superior de Agricultura "Luiz de Queiroz", Universidade de São Paulo.

St. MARTIN, S.K. Epistasis and soybean breeding. Soybean Genetics Newsletter, Ames,v.8: p. 104-107, Apr. 1981.

SUMARNO; FEHR, W.R. Response to recurrent selection for yield in soybeans. Crop Science, v.22, n.2, p.295-299, Mar./Apr. 1982.

TAI, G.C.C. Genotypic stability analyses and its application to potato regional trials. Crop Science, v.2, p.184-194, 1971.

TINIUS, C. N.; BURTON, J. W.; CARTER Jr., T.E. Recurrent selection for seed size in soybean: I. Response to selection in replicate populations. Crop Science, v.31, p.1137-1141, 1991 
TINIUS, C. N.; BURTON, J. W.; CARTER Jr., T.E. Recurrent selection for seed size in soybean: II. Indirect effects on seed growth rate. Crop Science, v.32, p.1480-1483, 1992.

TINIUS, C. N.; BURTON, J. W.; CARTER Jr., T.E. Recurrent selection for seed size in soybean: III. Indirect effects on seed composition. Crop Science, v.33, p.959-962, 1993.

TOLEDO, J.F.F. ; KIIHL, R.A.S. Análise do modelo genético envolvido no controle de dias para florescimento em soja. Pesquisa Agropecuária Brasileira. v.17, n.4, p.623-631, 1982.

TOLEDO, J.F.F.; ALMEIDA, L.A.; HILL, R.F.S.; MENOSSO, O.G. Ganho genético em soja no Estado do Paraná, via melhoramento. Pesquisa Agropecuária Brasileira, v.25, p.89-94, 1990.

TOLEDO, J.F.F.; OLIVEIRA, M.F.; TSUTIDA, A.C.; KIIHL, R.A.S. Genetic analysis of growth of determinate soybean genotypes under three photoperiods. Brazilian Journal of Genetics, v.16, n.3, p.713-748. Sept, 1993.

TOLEDO, J.F.F.; TRILLER, C.; DONATO, L.T.; OLIVEIRA, M.F.; TSUTIDA, A.C. Genetic control of flowering in determinate soybean genotypes under diverse photoperiods. Brazilian Journal of Genetics, v.17, n.2, p.187-195. June, 1994.

UPHOFF, M.D.; FEHR, W.R.; CIANZIO, S.R. Genetic gain for soybean seed yield by three recurrent selection methods. Crop Science, v.37, p.1155-1158, 1997.

VAN RAAMSDONK, L.W.D. The cytological and genetical mechanisms of plant domestication exemplified by four crop models. Botanic Review, v.61, p.367-399. 1995. 
VEGA, O.U.A. Comparacion de diferentes parametros de estabilidad del rendimento en trigo. Revista de la Facultad de Agronomia, v. 13, n. 1/4, p.291-309, 1984.

VELLO, N.A. Ampliação da base genética do germoplasma e melhoramento da soja na ESALQ/USP.In: SIMPÓSIO SOBRE A CULTURA E PRODUTIVIDADE DA SOJA, 1., Piracicaba, 1991. Anais. Piracicaba: FEALQ, 1992. p.60-81.

VELLO, N.A. Métodos de Melhoramento da Soja. In: SIMPÓSIO SOBRE A CULTURA E PRODUTIVIDADE DA SOJA, 1., Piracicaba, 1991. Anais. Piracicaba: FEALQ, 1992b. p.41-59.

VELLO, N. A. Base genética, fontes de genes e métodos de melhoramento para resistência a doenças. In: ENCONTRO SOBRE TEMAS DE GENÉTICA E MELHORAMENTO, 12., Piracicaba, 1995. Anais. Piracicaba:ESALQ, Depto. de Genética, 1995. p.11-23.

VELLO, N.A.; FEHR, W.R.; BAHRENFUS, J.B. Genetic variability and agronomic performance of soybean populations developed from plant introdutions. Crop Science, v.24, n.3, p.511-514, 1984.

VELLO, N.A.; HIROMOTO, D.M.; AZEVEDO FILHO, A.J.B.V. Coefficient of parentage and breeding of Brazilian soybean germplasm. Revista Brasileira de Genética, v.11, n.3, p.679-697, Sep.1988.

VENCOVSKY, R. ; BARRIGA, P. Genética biométrica no fitomelhoramento Ribeirão Preto: Sociedade Brasileira de Genética, 1992. 486p.

WEAVER, D.B. ; WILCOX, J.R. Heritabilities, gains from selection, and genetic correlations for characteristics of soybeans grown in two row spacings. Crop Science, Madison, v.22, p.625-629, 1982. 
WEBER, C.R. ; MOORTHY, B.R. Heritable and nonheritable relationships and variability of oil content and agronomic characters in the $F_{2}$ generation of soybean crosses. Agronomy Journal, v.44, n.4, p.202-209, 1952.

WEBER, W.E; QUALSET, C.O.; WRICKE, G. Selection strategies for the improvement of autogamous species. In: BROWN, A. H. D.; CLEEG, M. T; KAHLER, A. L.; WEIR. B. S., eds. plant population genetics, breeding and genetic resources. Sunderland: Sinauer Associates, 1990. cap.17, p.299-316.

WEISS, M.G. Soybeans. Advances in Agronomy, v.1, p.77-157, 1949.

WERNER, B.K. ; WILCOX, J.R. Recurrent selection for yield in Glycine max using genetic male-sterility. Euphytica, v.50, p.19-26, 1990.

WRICKE, G. Zur berechnung der okovalenz bei sommerweizen und hafer. Zeitschrift Pflanzezzuchtg. v.52, p.127-138, 1965.

WRIGHT, S. Correlation and causation. Journal of Agricultural Research, v.20, n.7, p.557-585, 1921.

XU, H.; WILCOX, J.R. Recurrent selection for maturity and percent seed protein in Glycine max based on $\mathrm{S}_{0}$ plant evaluations. Euphytica, v.62, p.51-57, 1992.

XU, H.; ZHEN, H.; LU, Q.; ZHAO, S.; HU, Z. Three evidence of the original area of soybean.In: WORLD SOYBEAN RESEARCH CONFERENCE.. 4., Buenos Aires, 1988. Proceedings. Buenos Aires: Association Argentina de la Soja, 1989. p.124128. 
YOKOMIZO, G.K. Desempenho e variabilidade de topocruzamentos $\mathrm{F}_{5: 4}$ tipo alimento x tipo grão em soja. Piracicaba, 1994. 120p. Dissertação (Mestrado) - Escola Superior de Agricultura "Luiz de Queiroz", Universidade de São Paulo.

YOKOMIZO, G.K. Interação genótipos x ambientes em topocruzamentos de soja tipo alimento com tipo grão. Piracicaba, 1999. 171p. Tese (Doutorado) - Escola Superior de Agricultura "Luiz de Queiroz", Universidade de São Paulo.

YUE, G.L.; ROOZEBOOM, K.L.; SCHAPAUGH Jr., W.T; LIANG, G.H. Evaluation of soybean cultivars using parametric and nonparametric stability estimates. Plant Breeding, v.116, n.3, p.271-275, 1997.

YUE, G.L.; HEER, W.F.; MOYER, J.L.; MADDUX, L.D.; SORENSEN, E.L.; LIANG, G.H. Comparison of nonparametric and parametric stability estimates to evaluate alfafa cultivars. Journal of Genetics and Breeding, v.50, n. 1, p.67-74, 1996.

ZHIHONG, H; JUNZHENG, Z. Study on soybean recurrent selection applied to male sterility. Soybean Genetics Newsletter, v. 18, p.86-89, 1991

ZOBEL, R.W.; MADISON, J.W.; GAUCH Jr, H.G. Statistical analysis of a yield trial. Agronomy Journal, v.80, p.388-393, 1988. 
TABELAS 


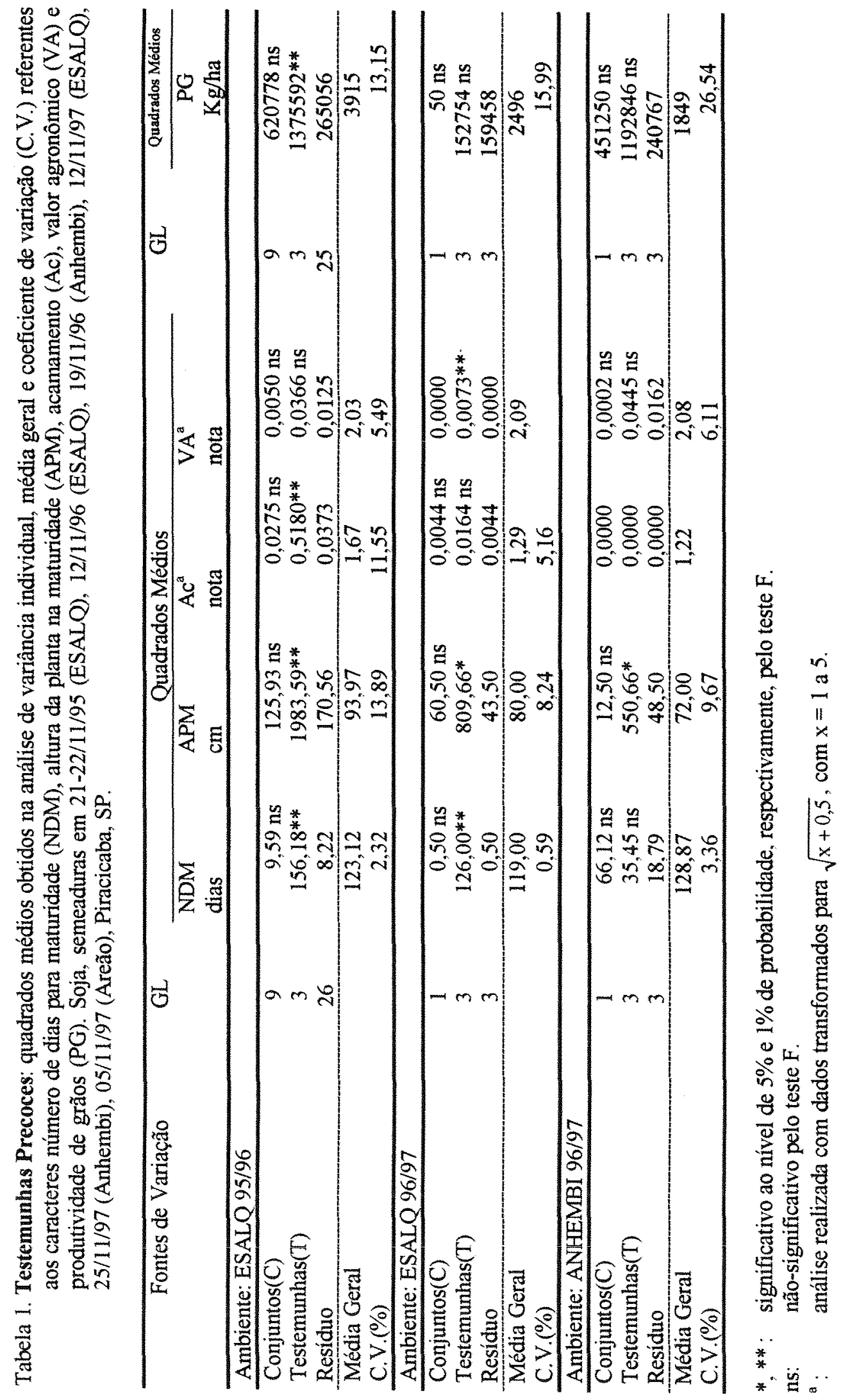




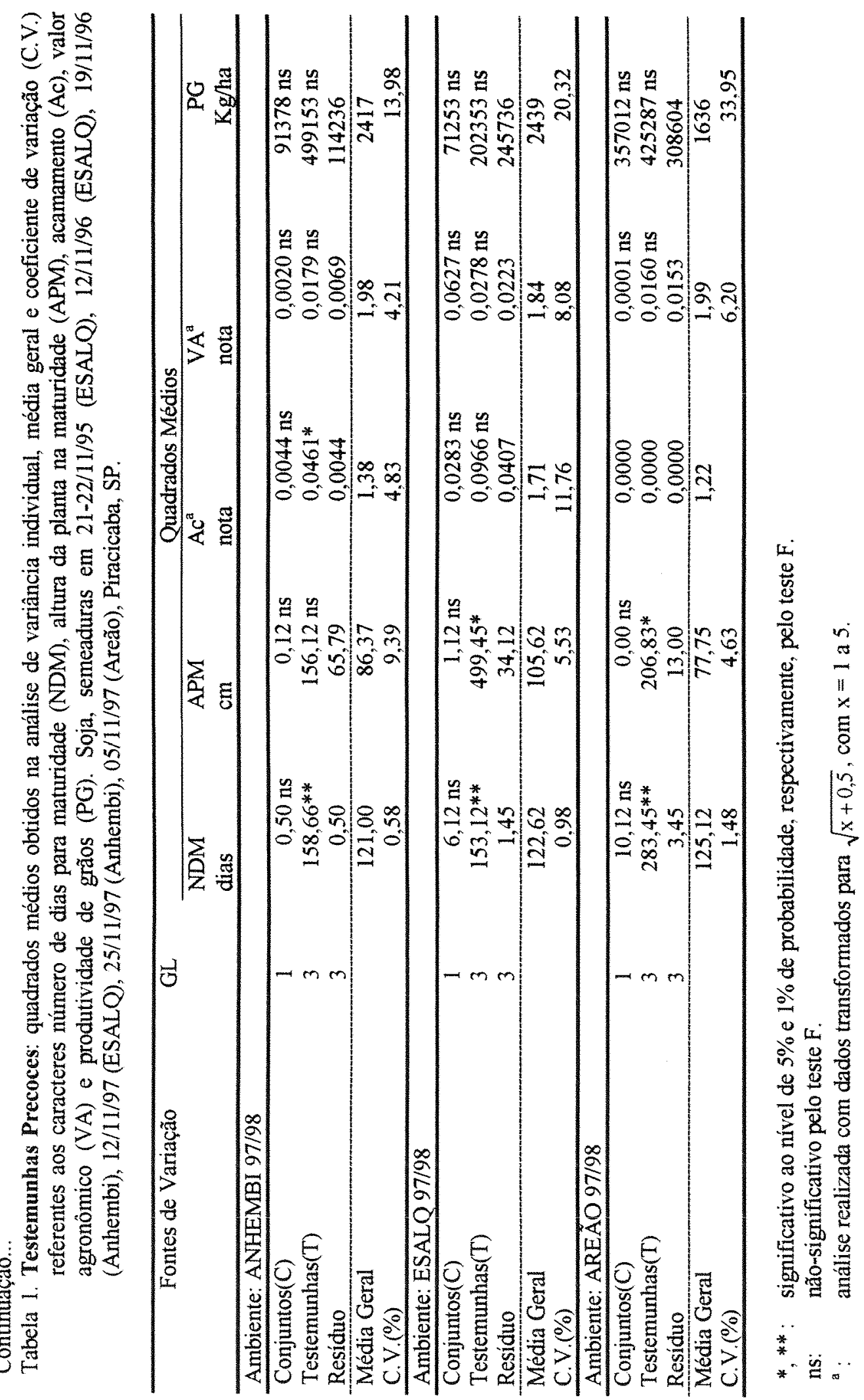




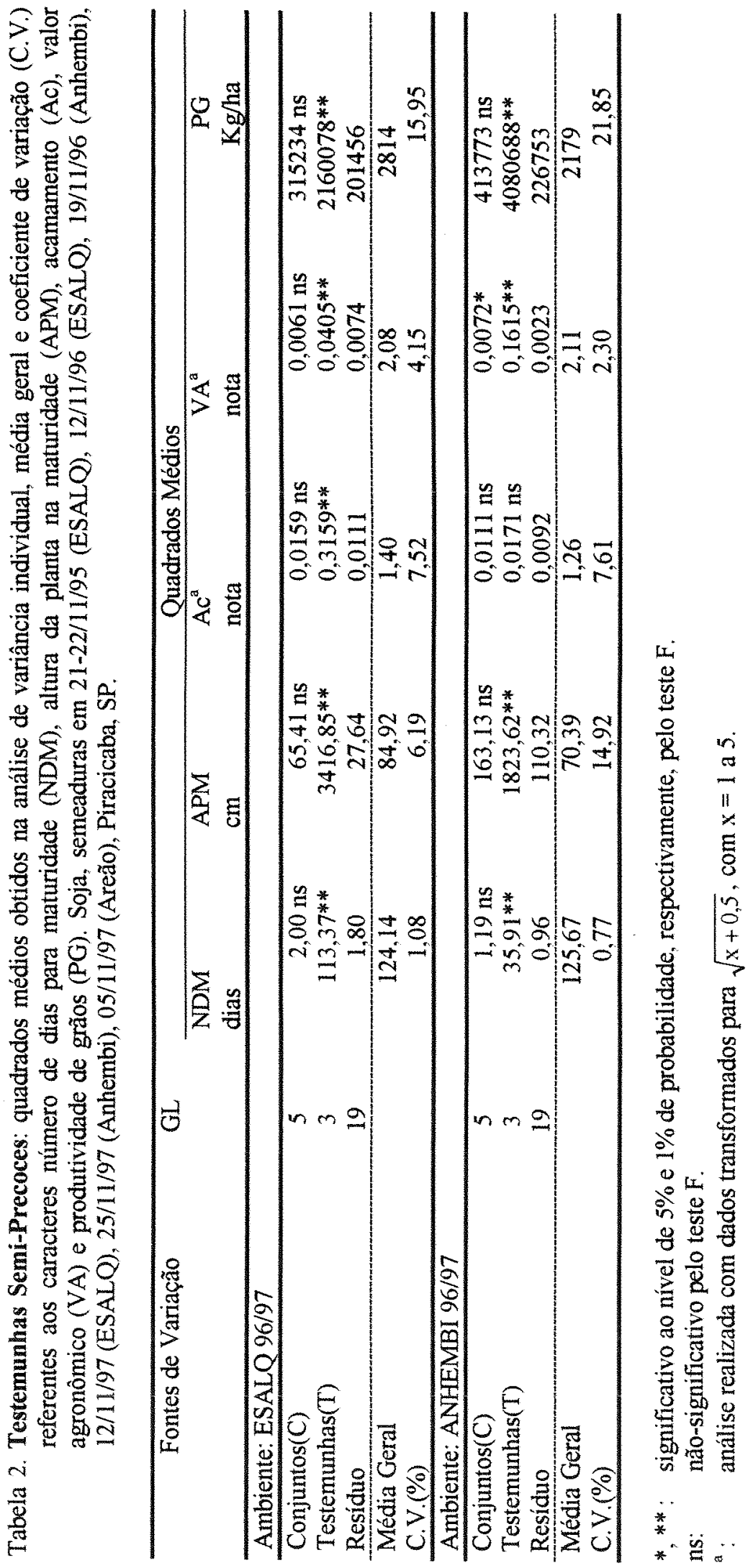




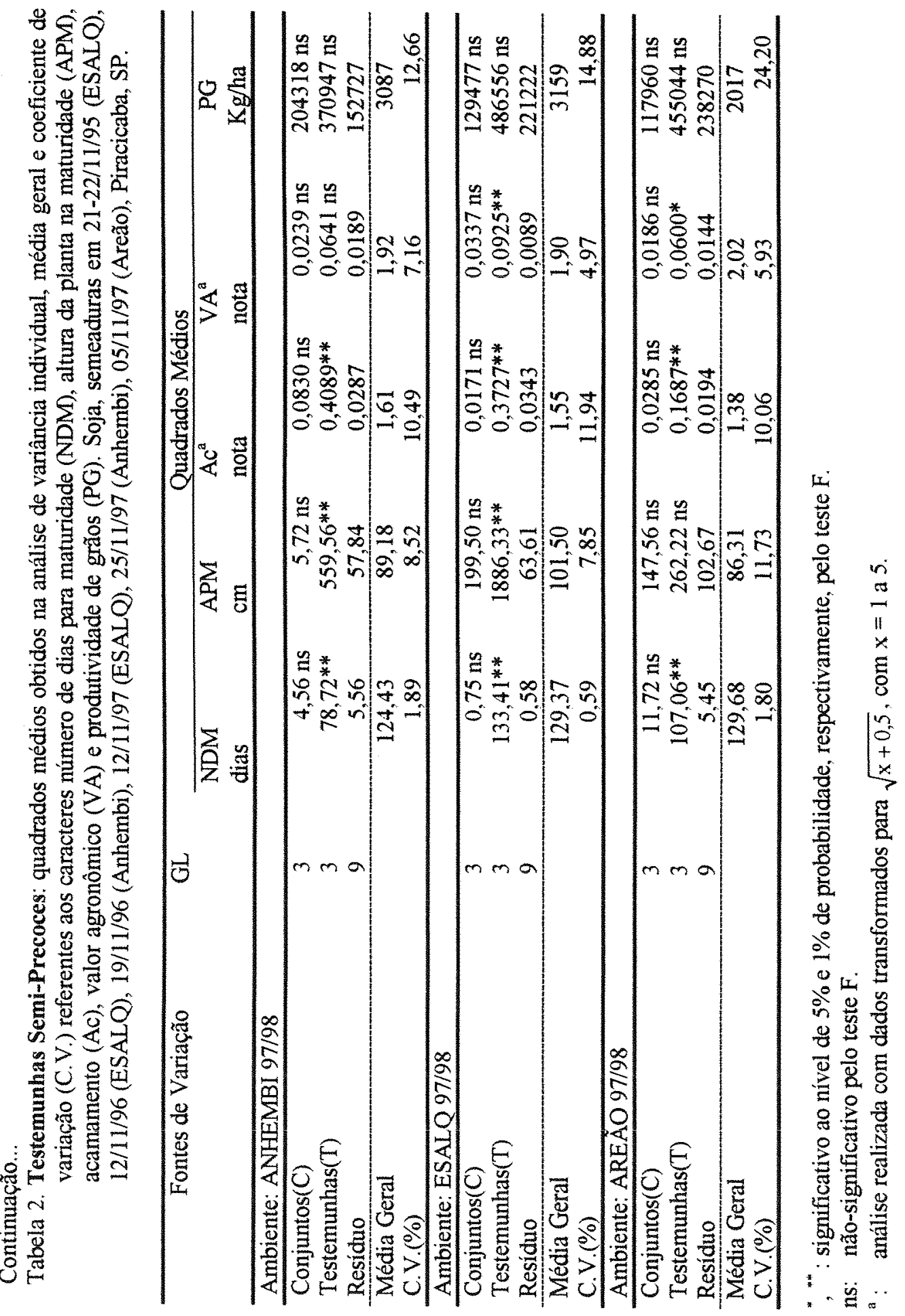




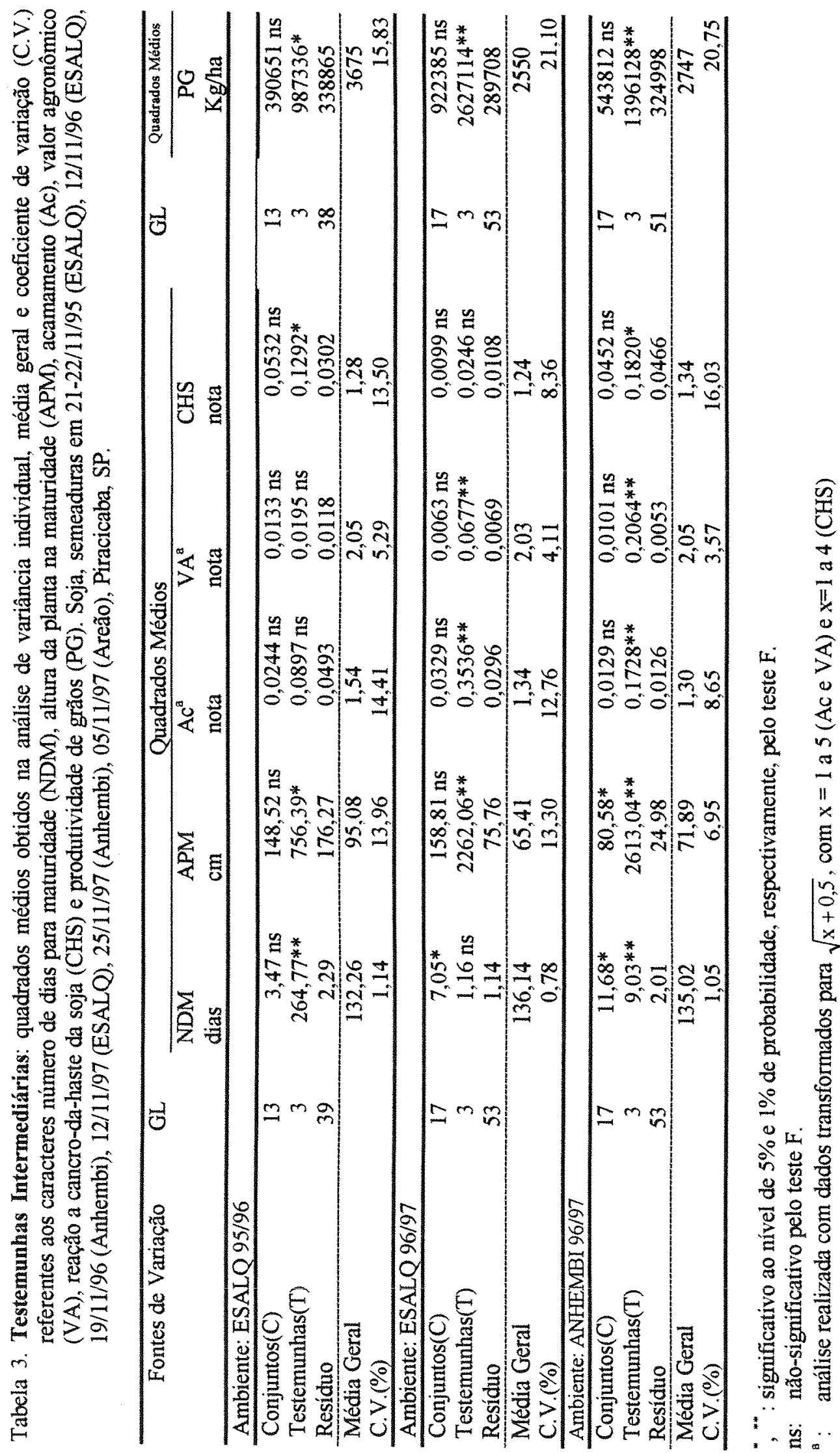




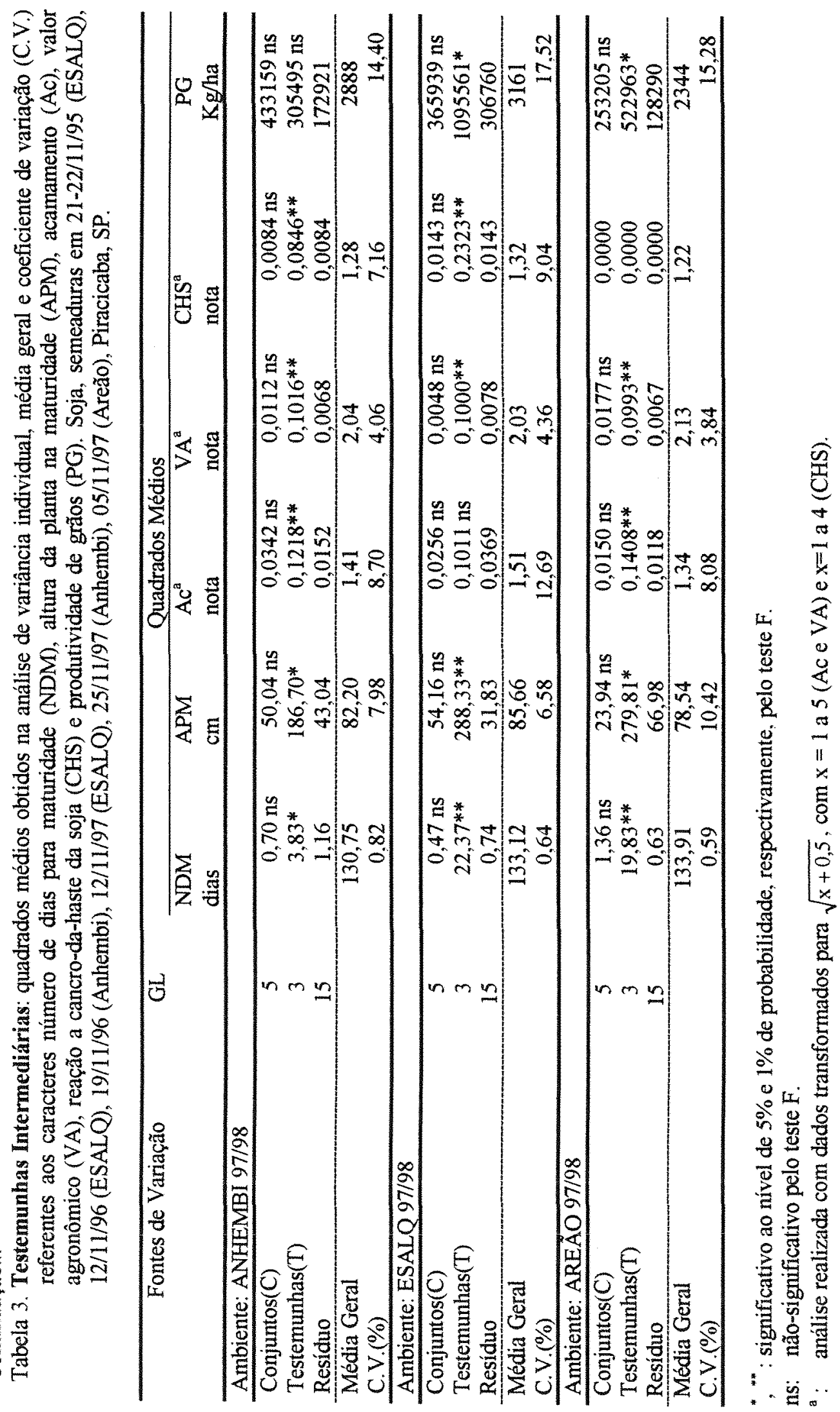




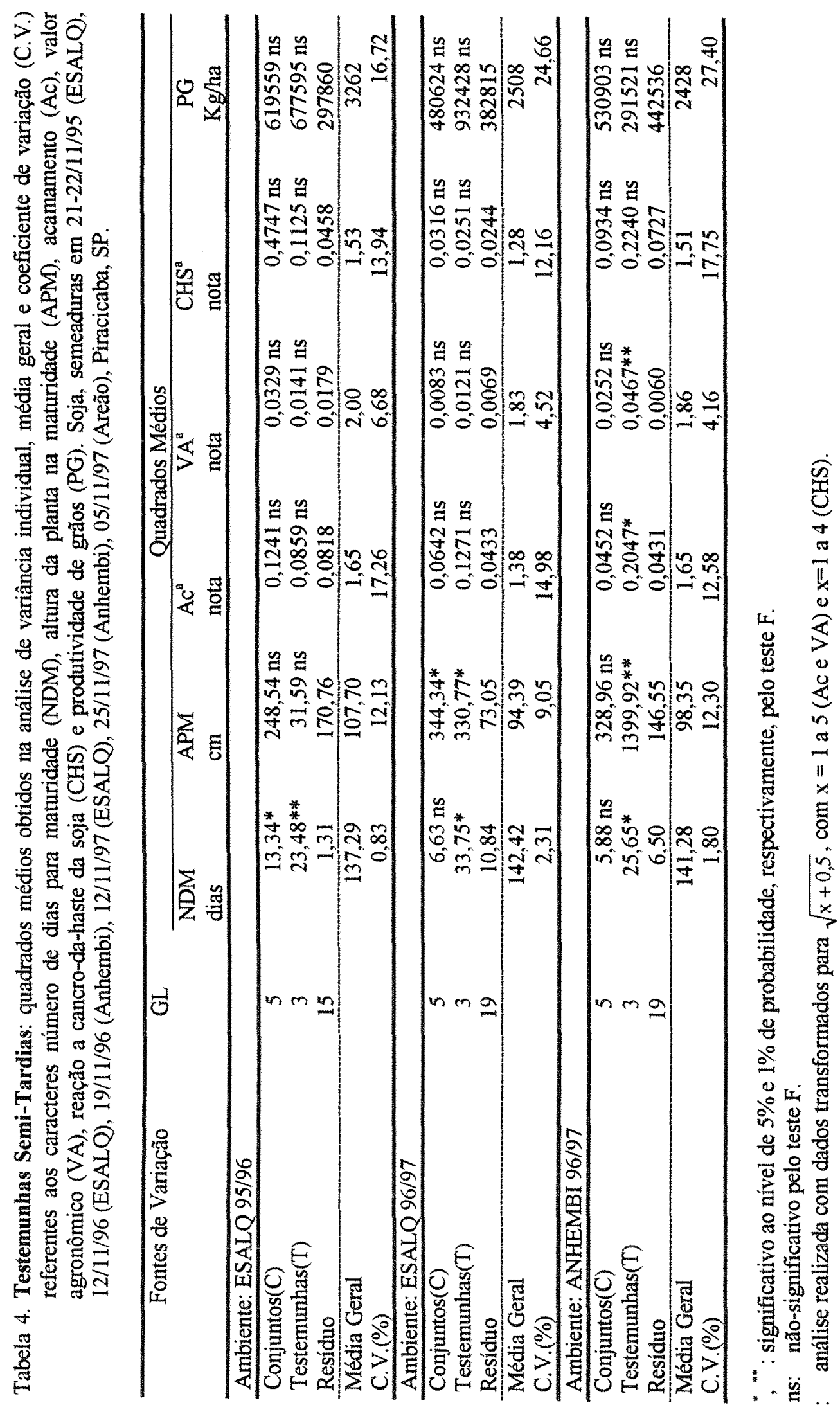




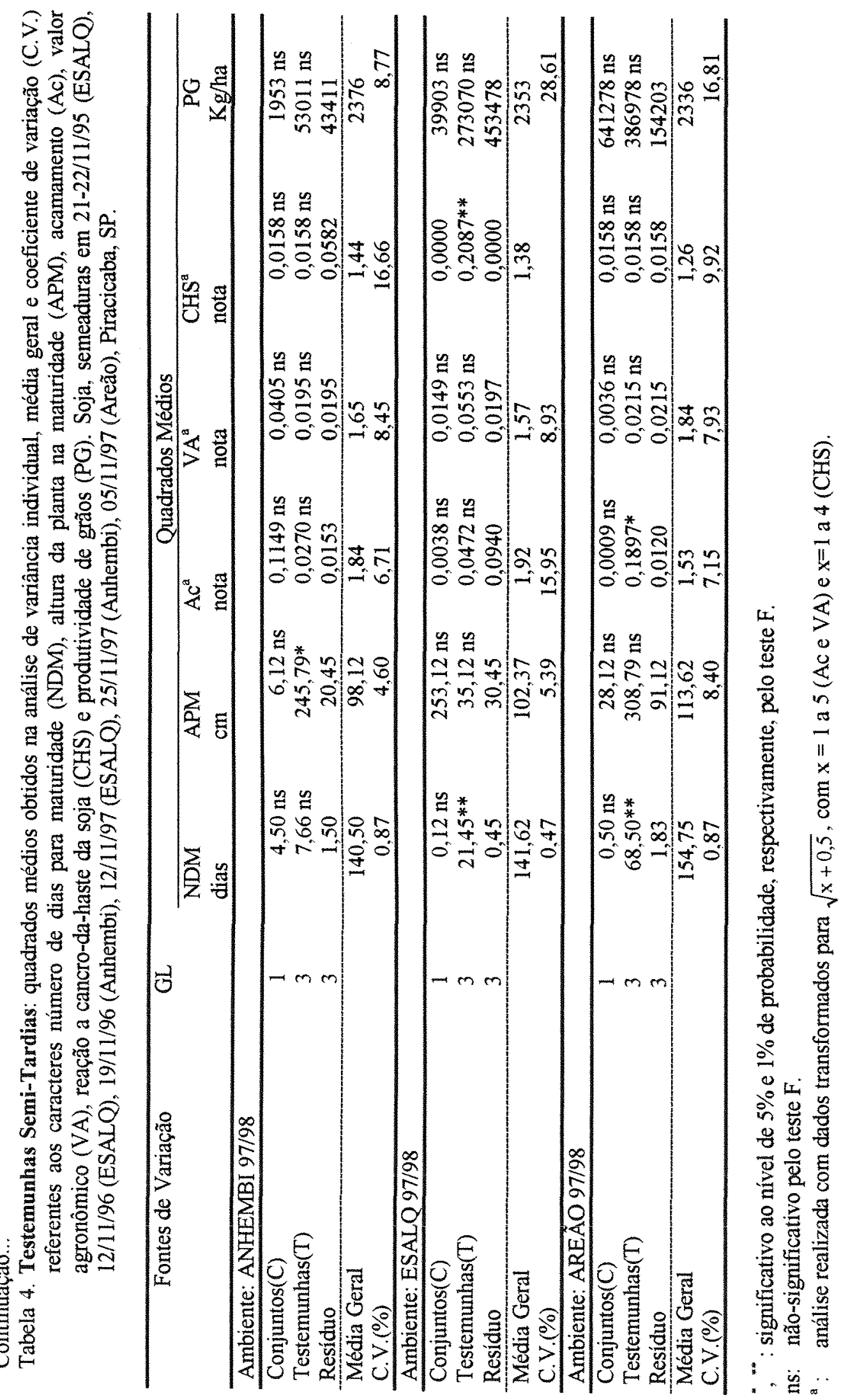




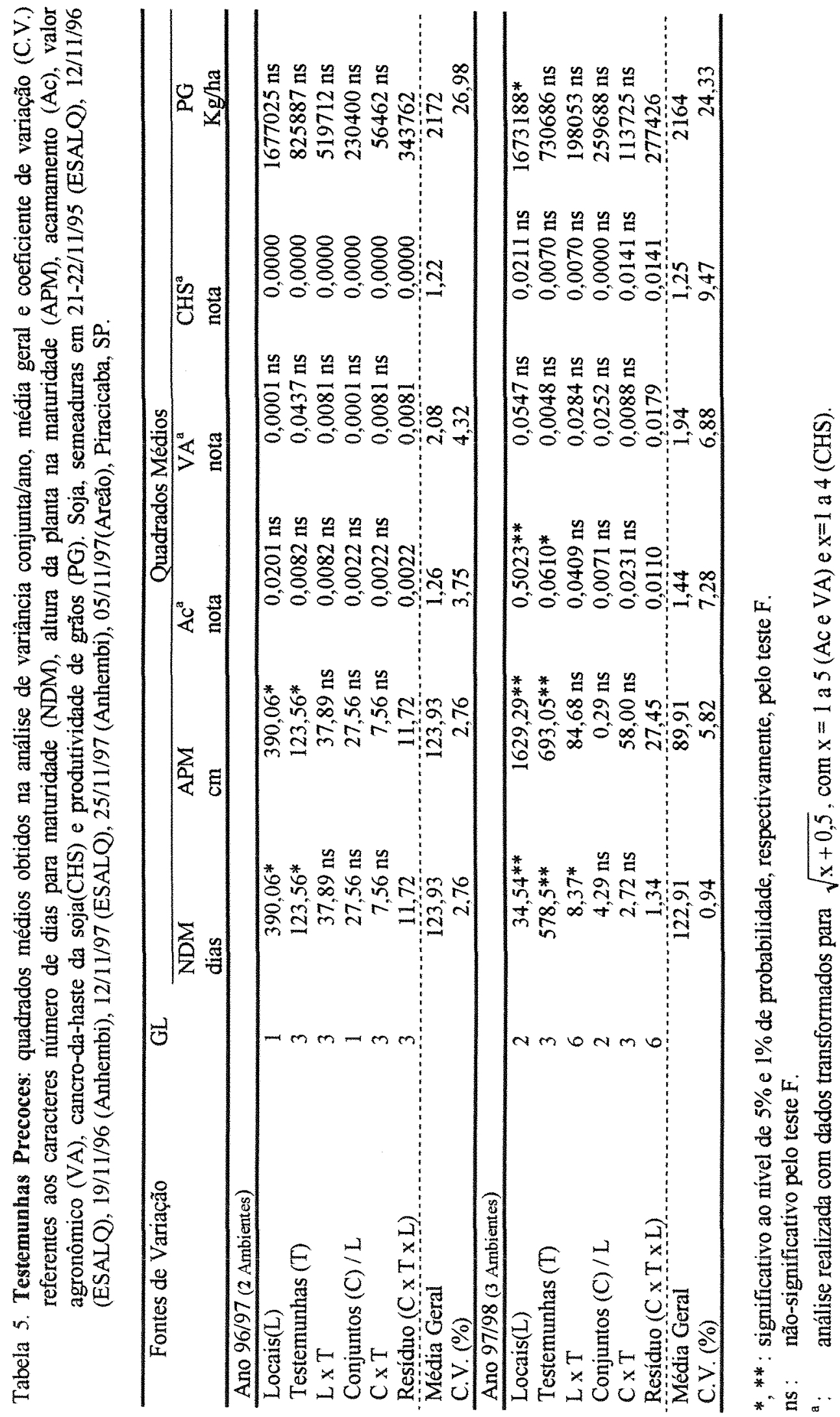




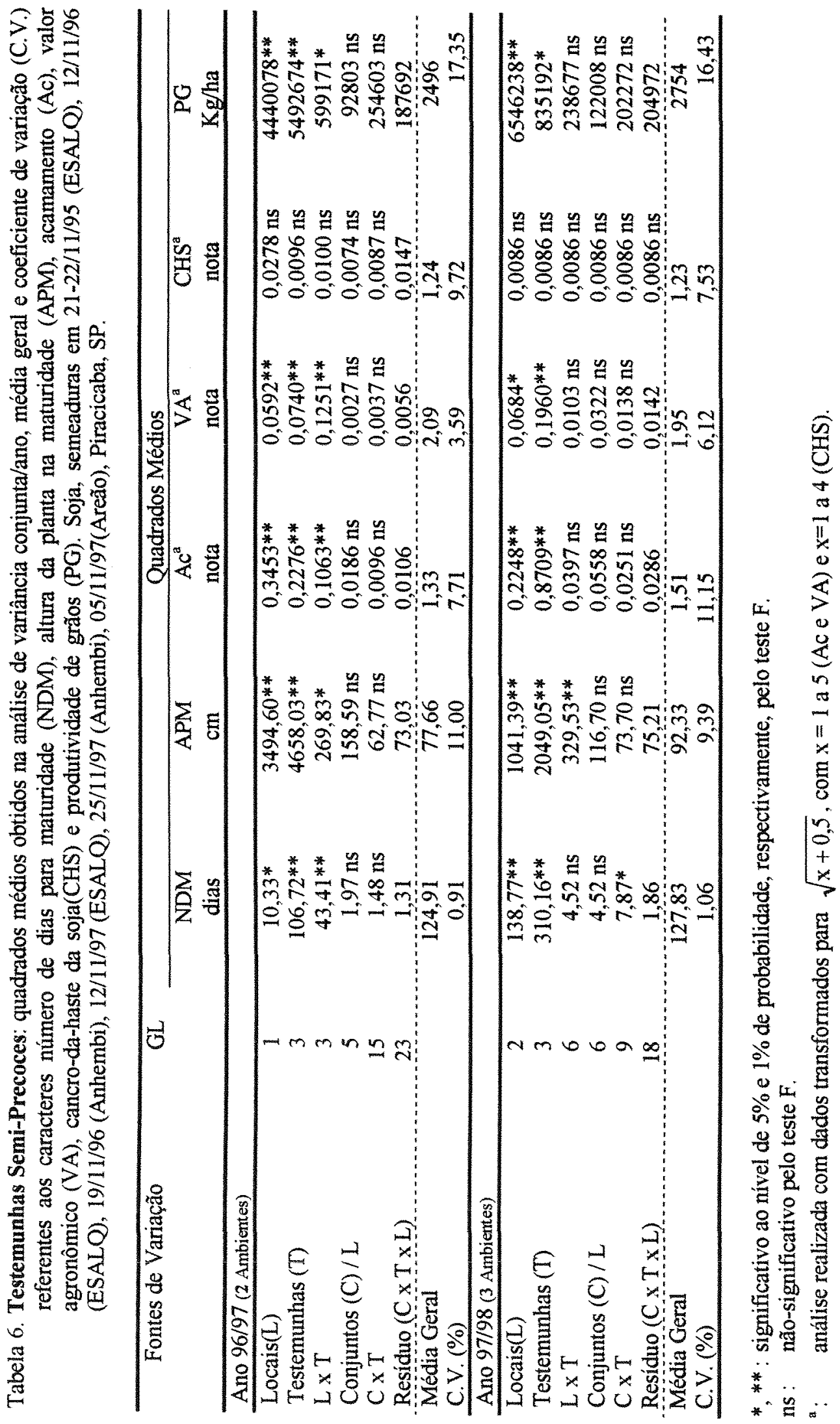




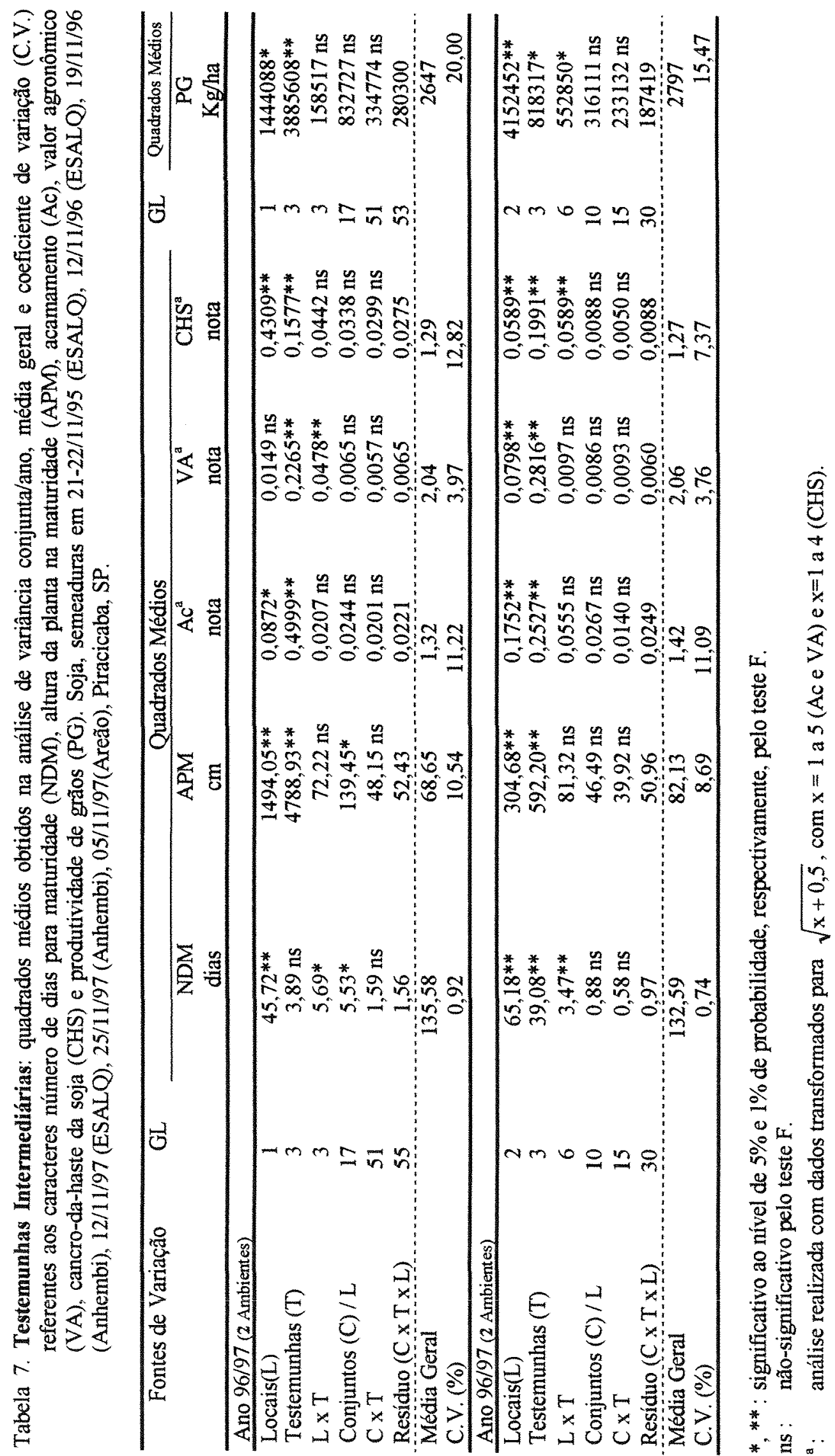




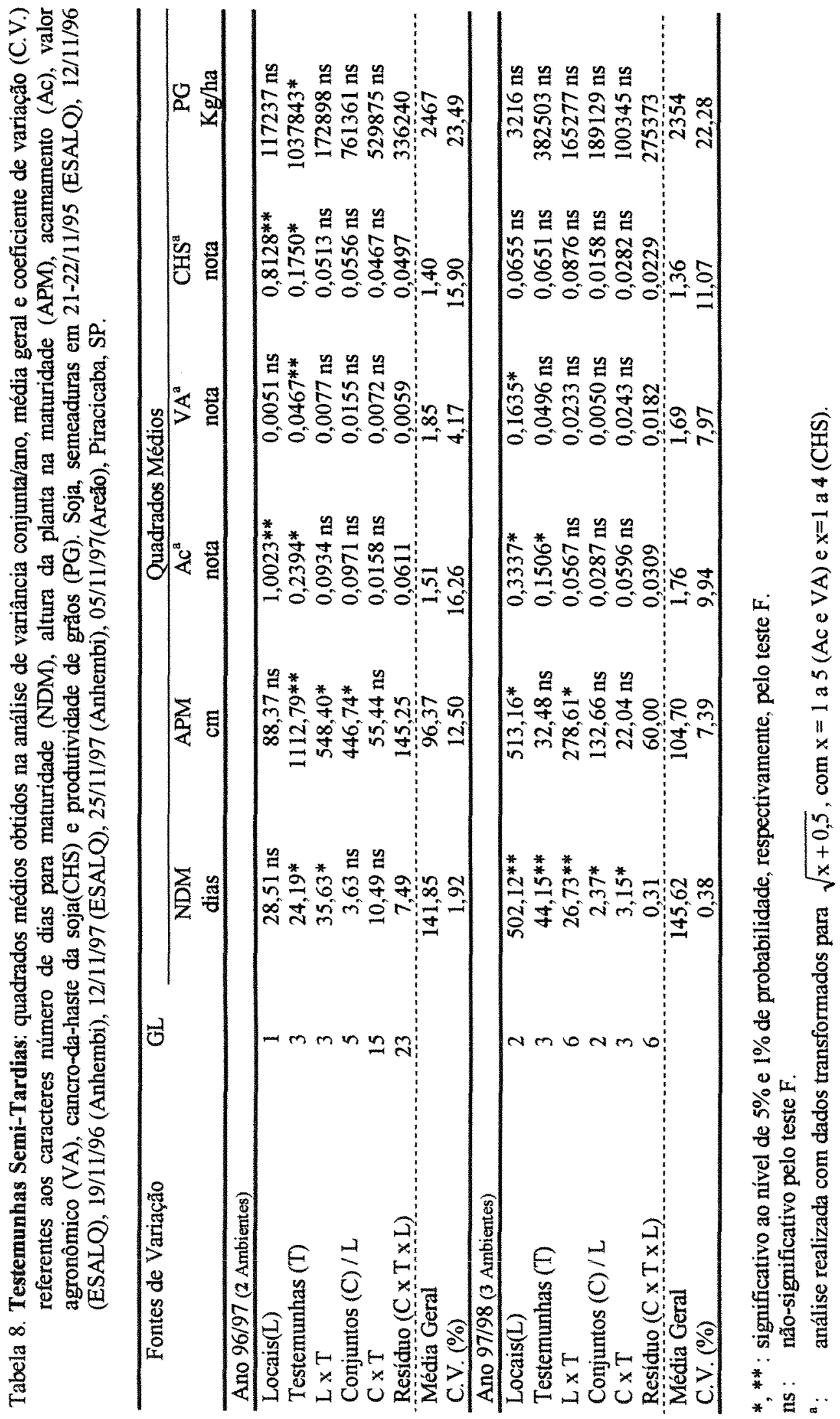




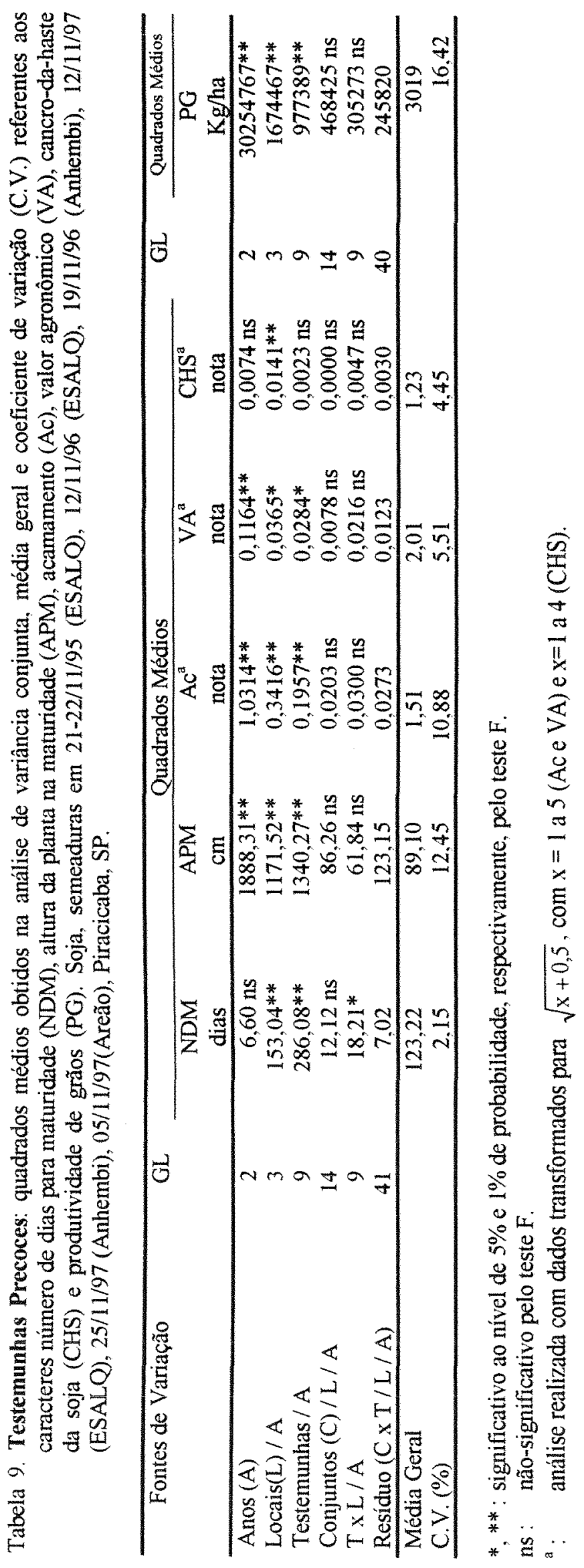


宅

옹

要。

욜

ษ 青

莺 总

엉 त्ञ

- $\overrightarrow{\mathrm{N}}$

공

an on

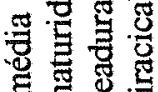

要

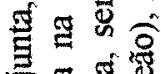

寻焉的总

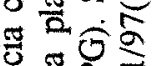

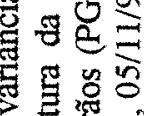

和需

论语要

\%

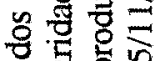

몸

参鄫要

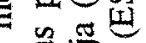

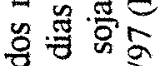

읭

를은

的

\&

政

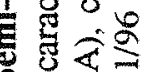

늠릉

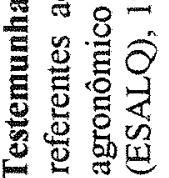

은

촐

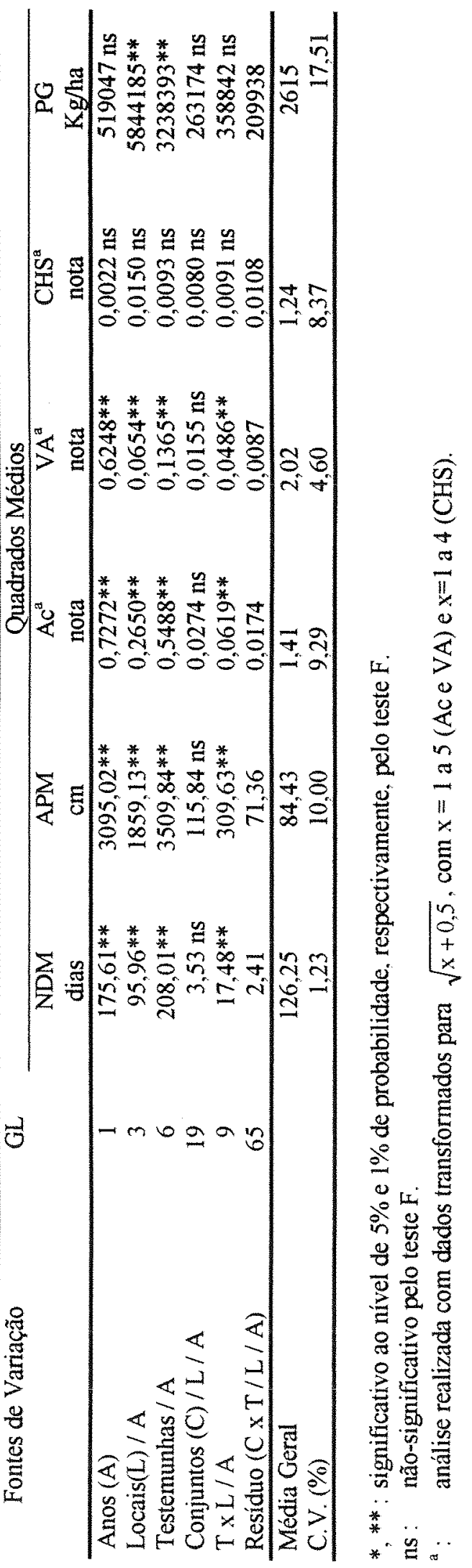




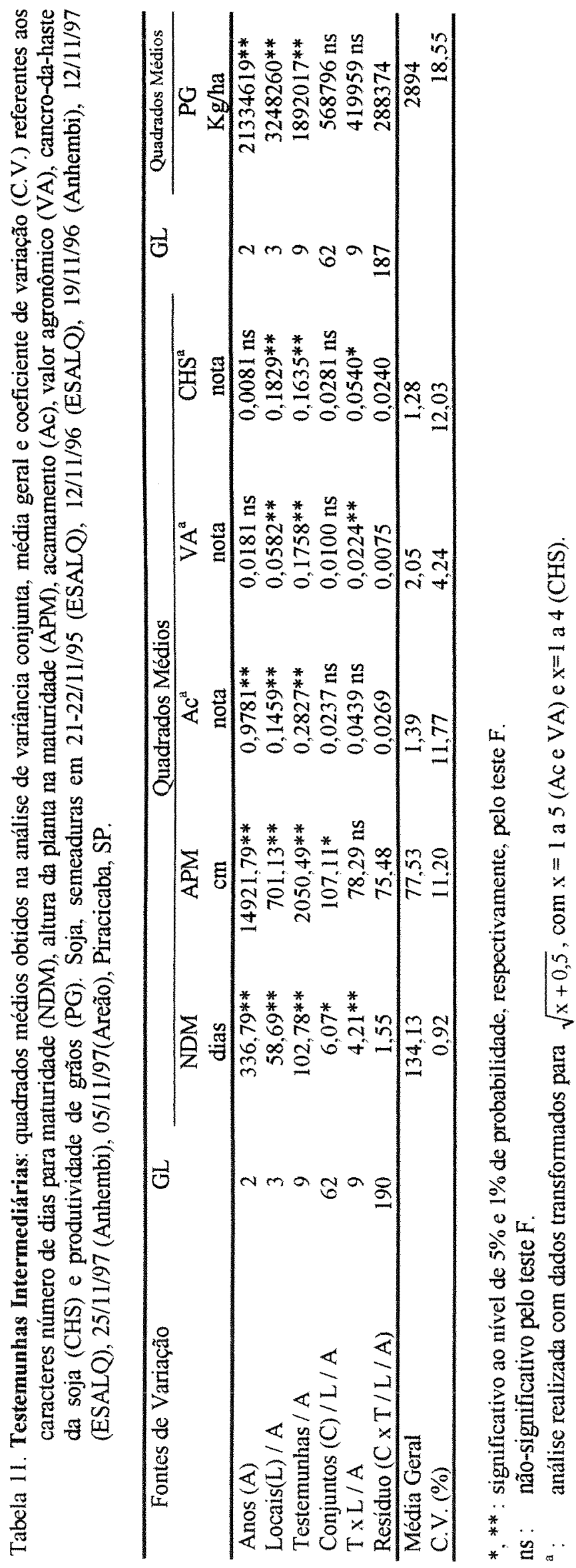




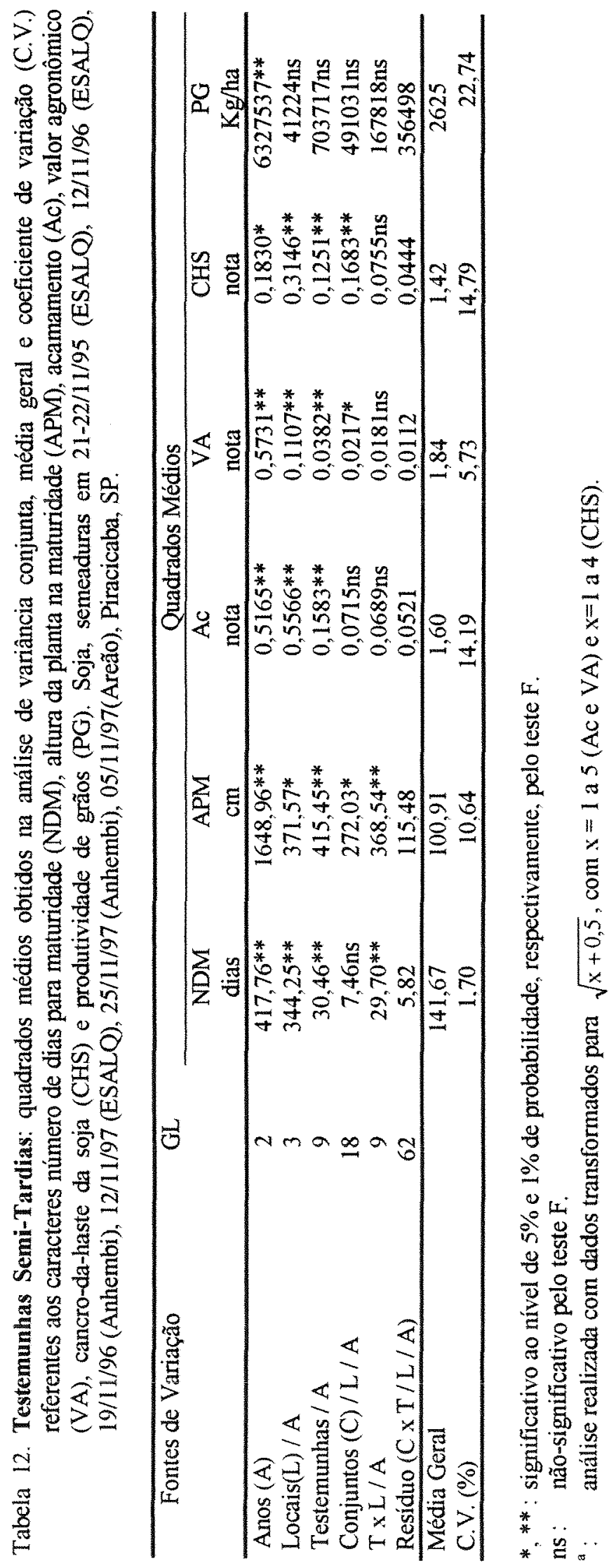




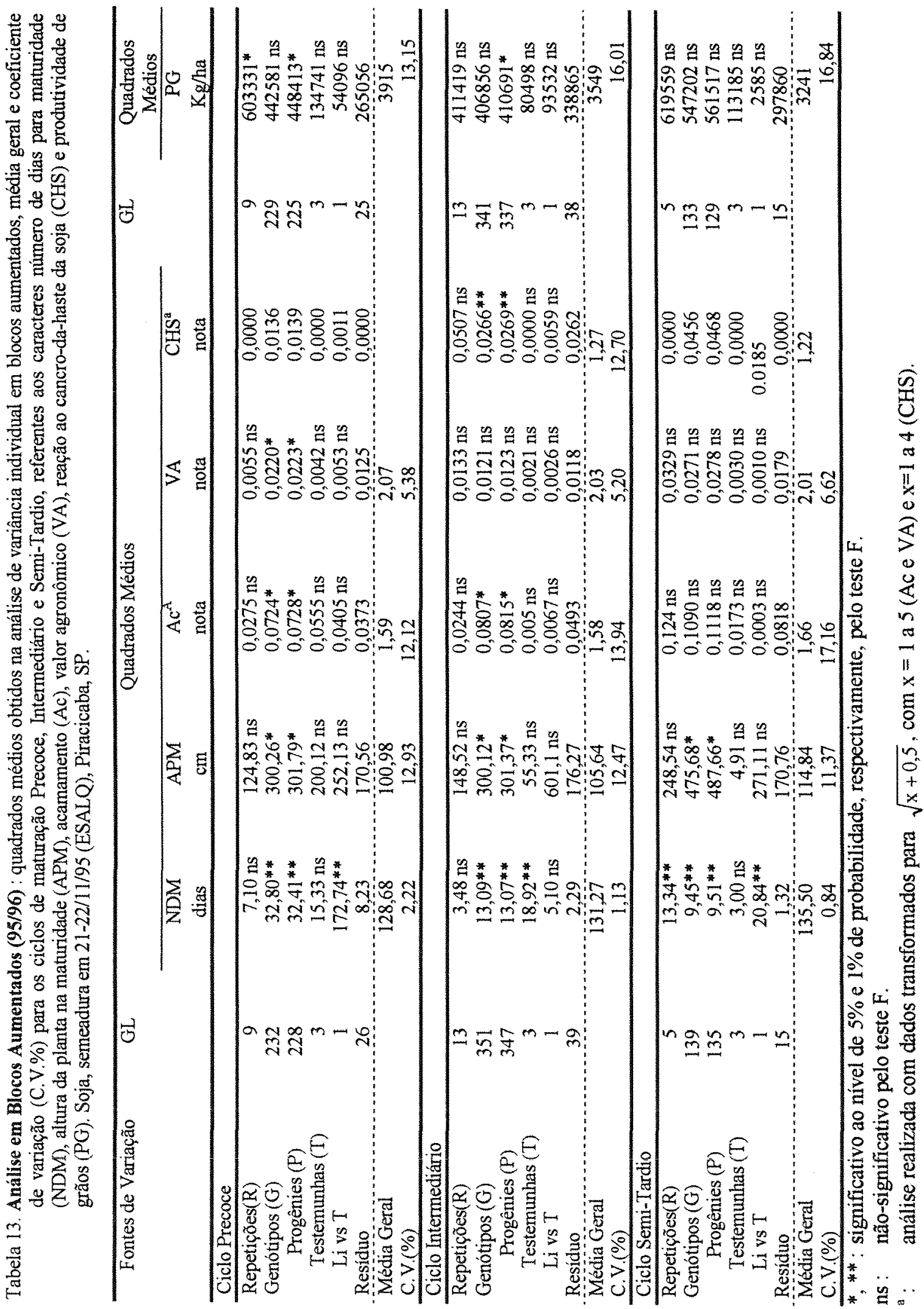




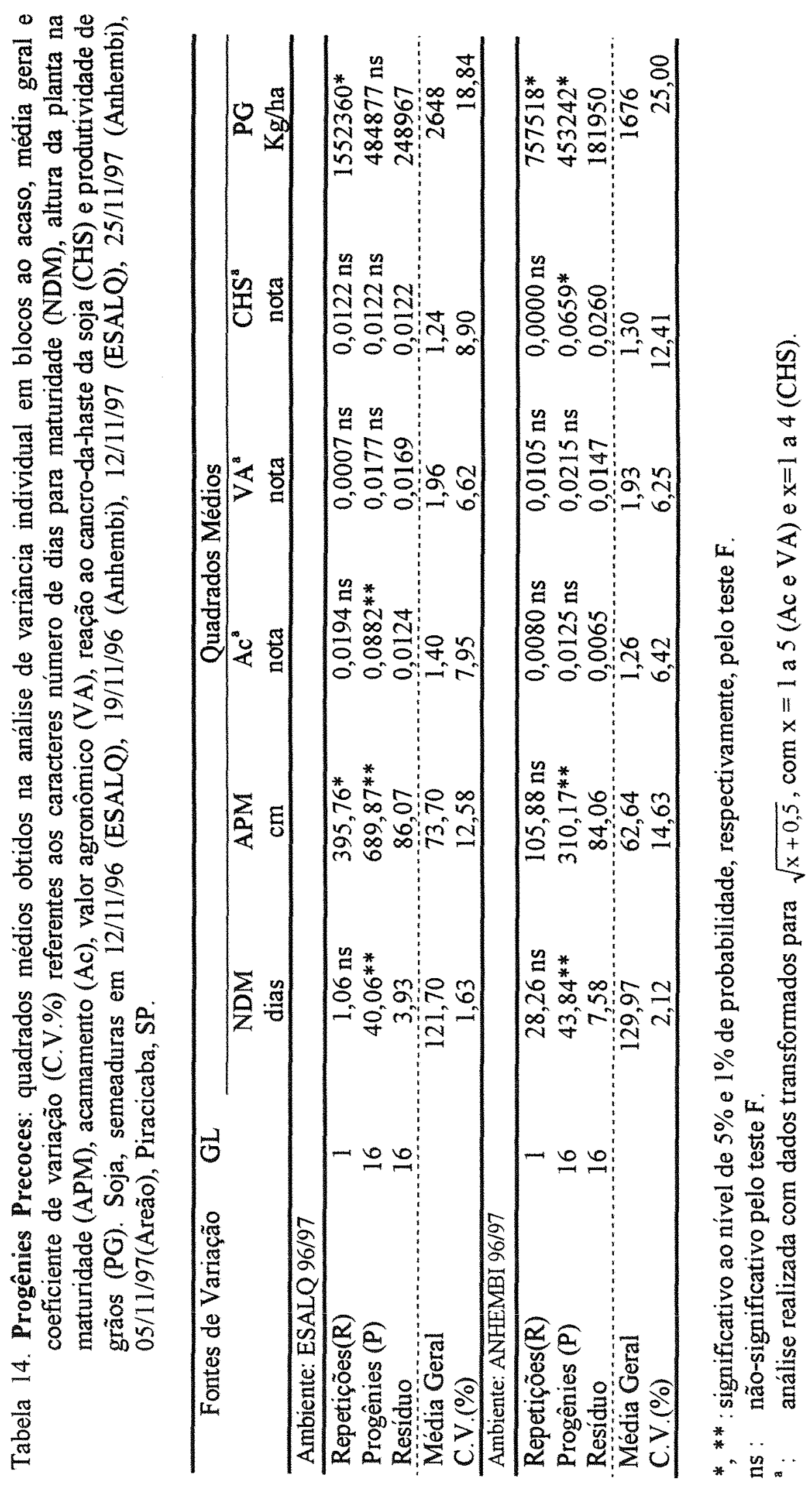




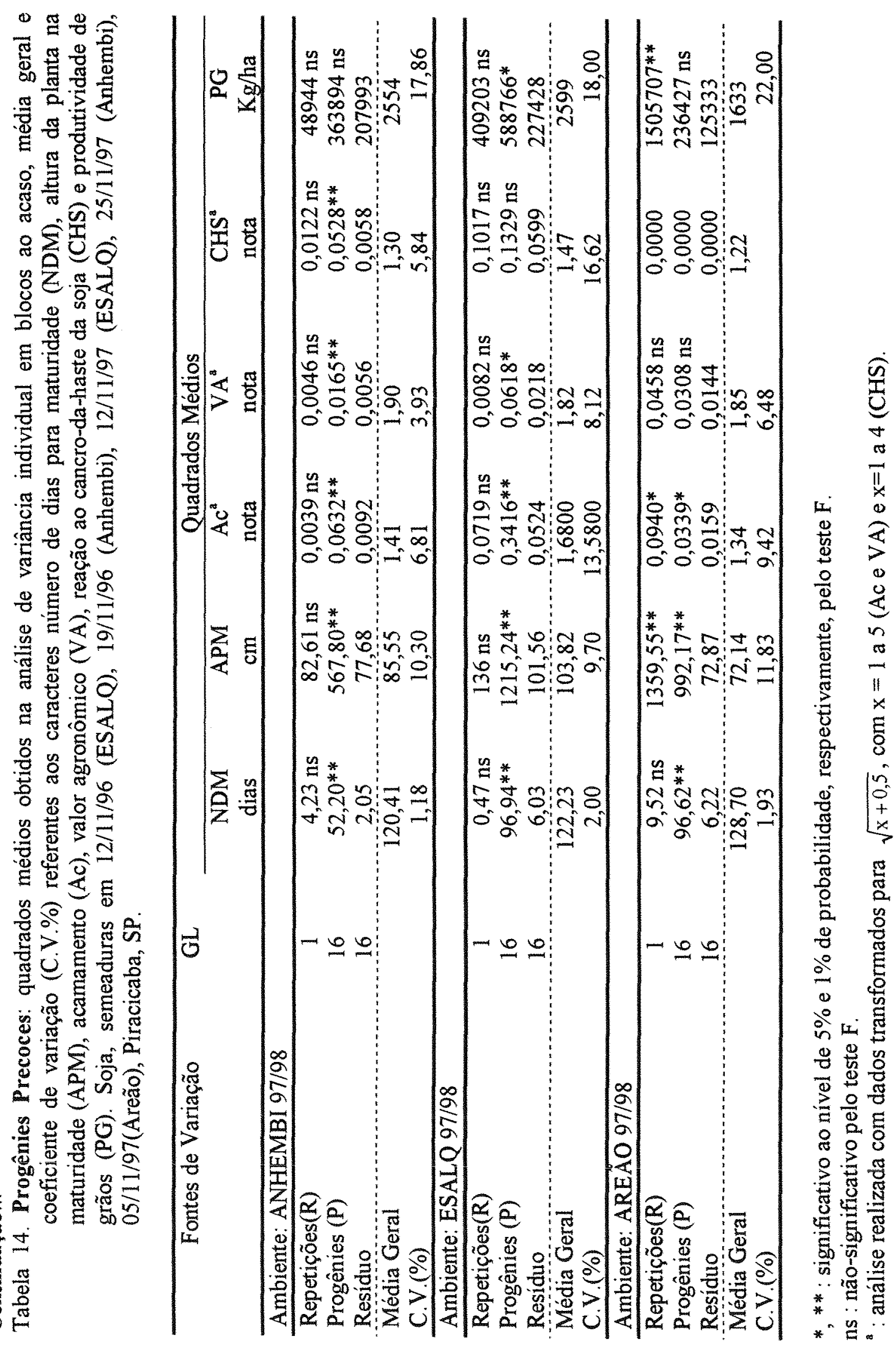




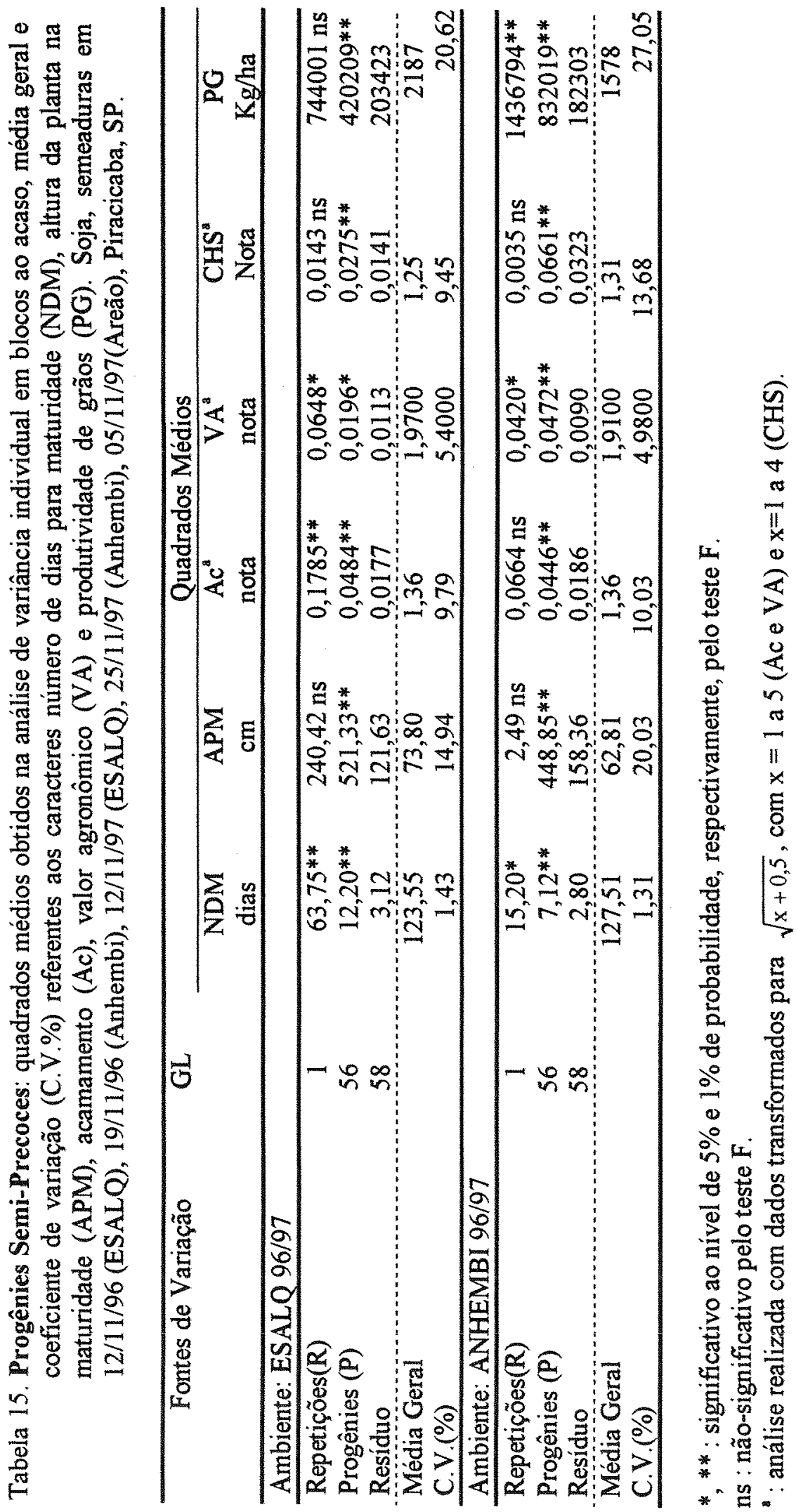




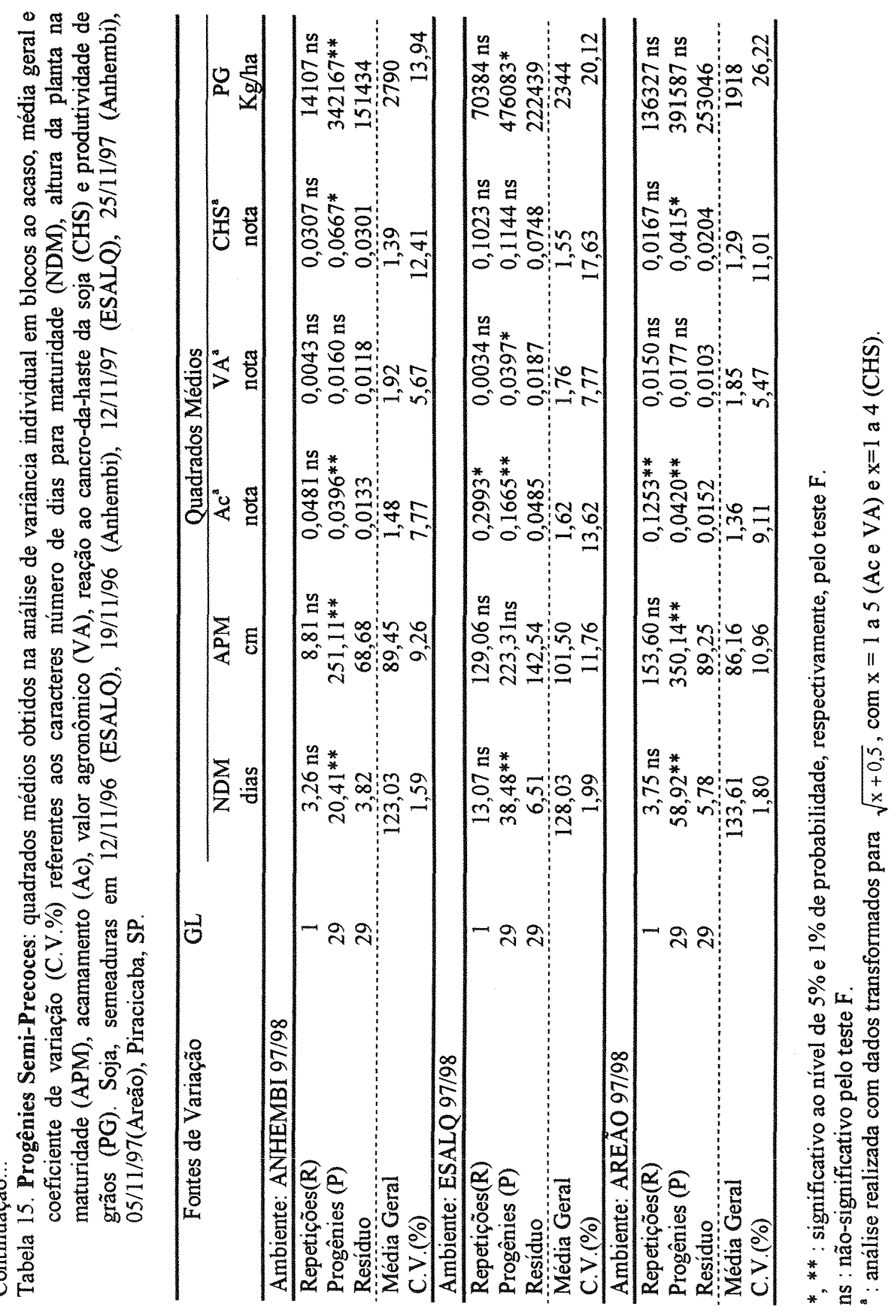




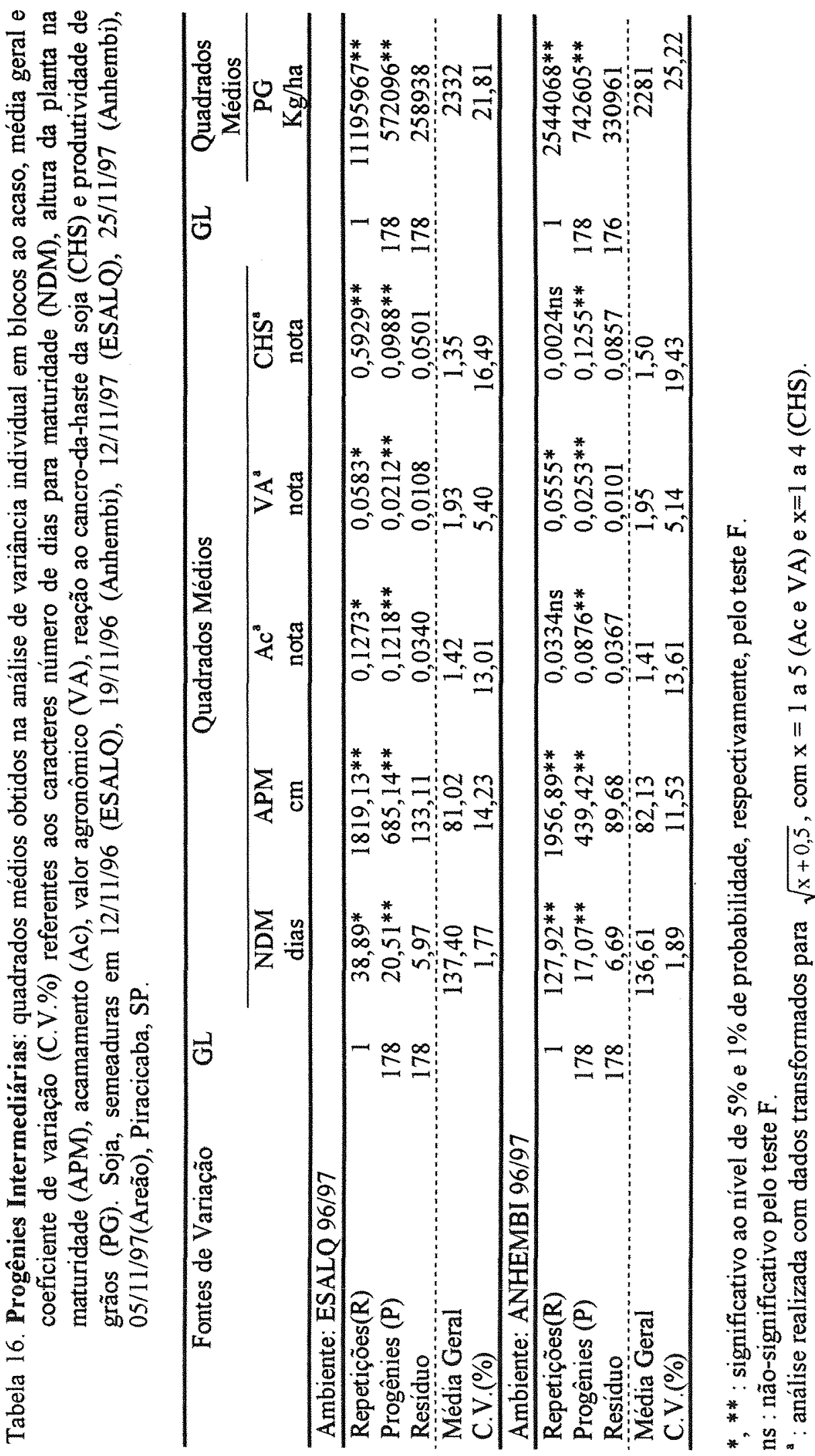




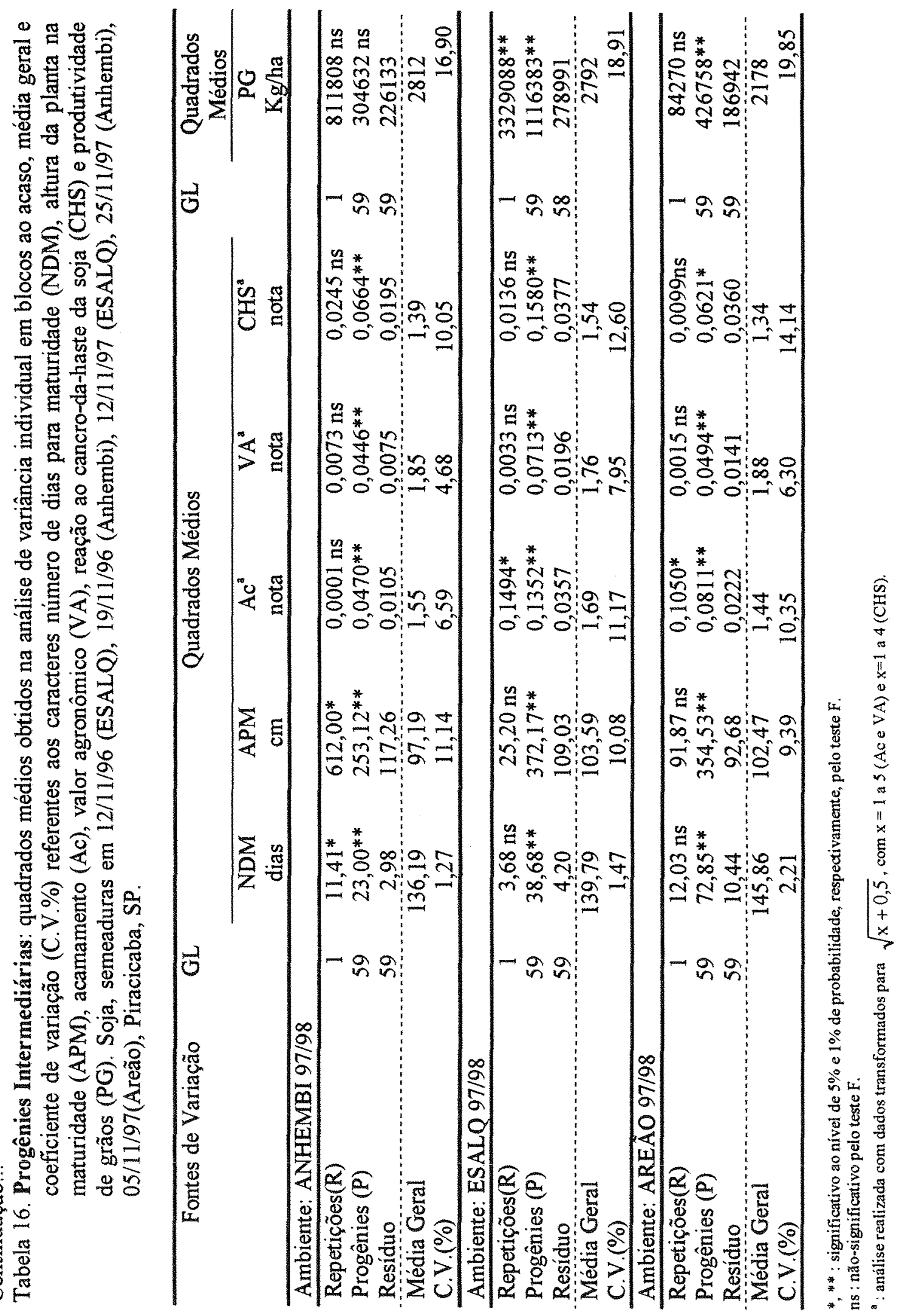




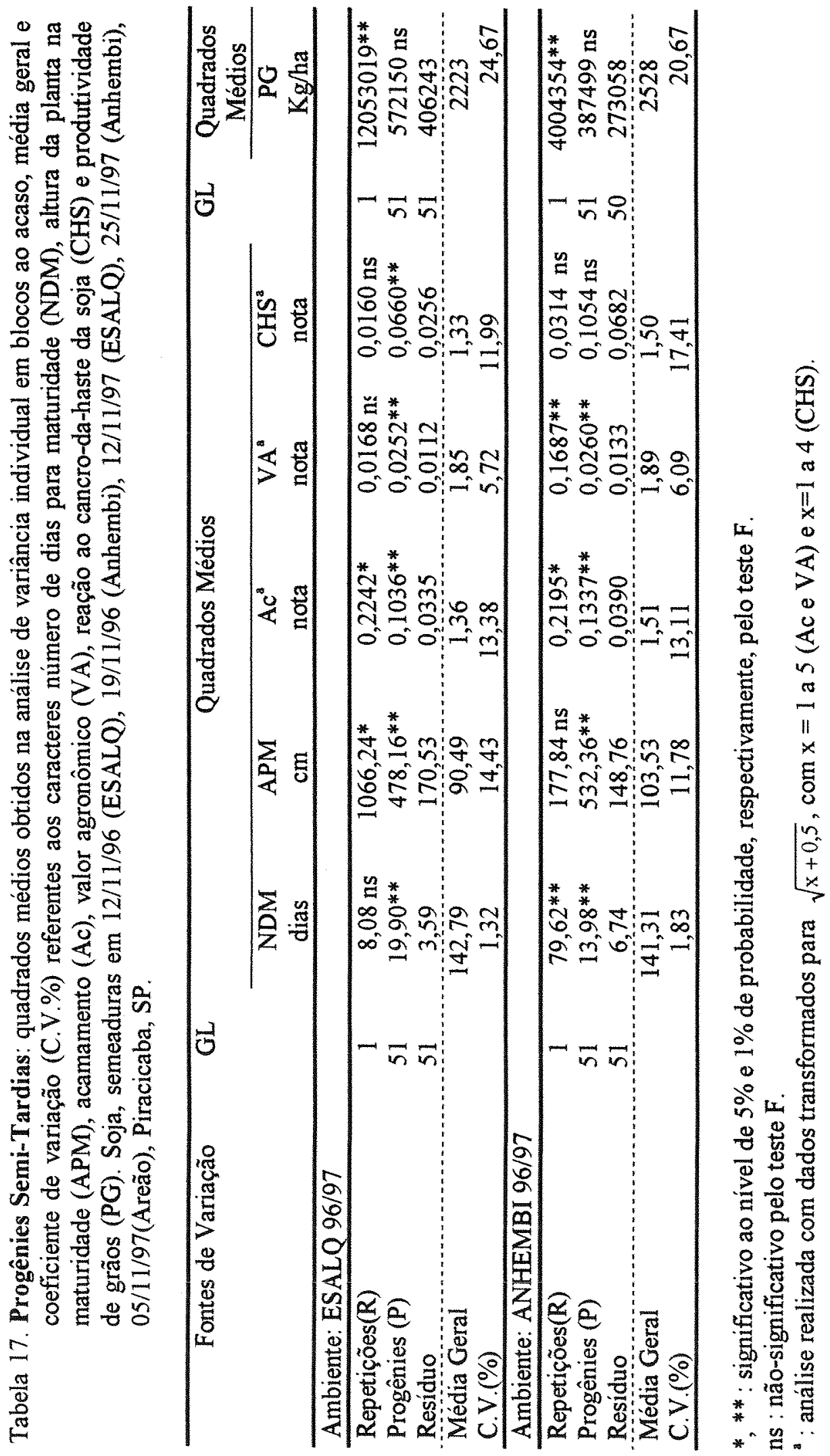




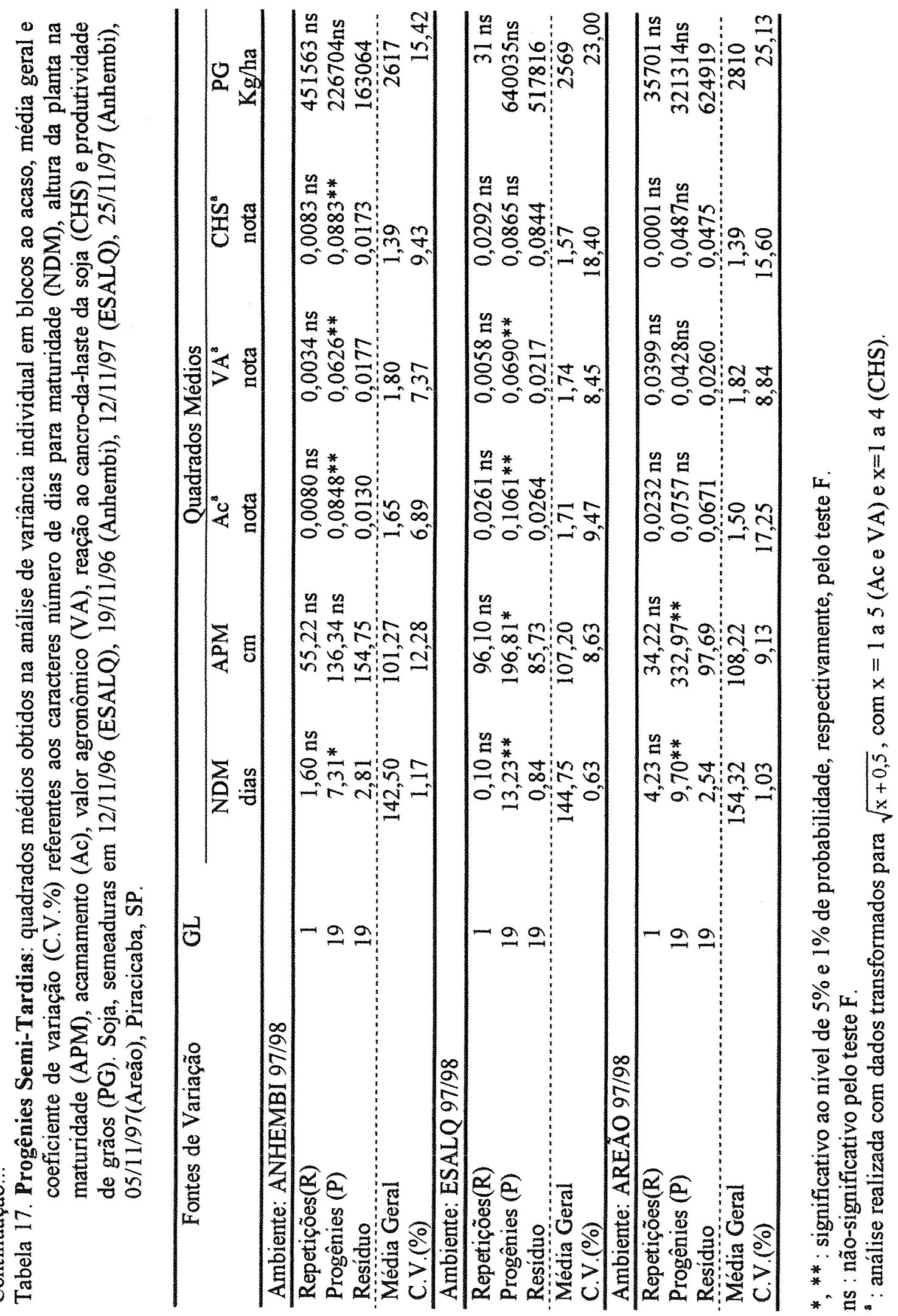




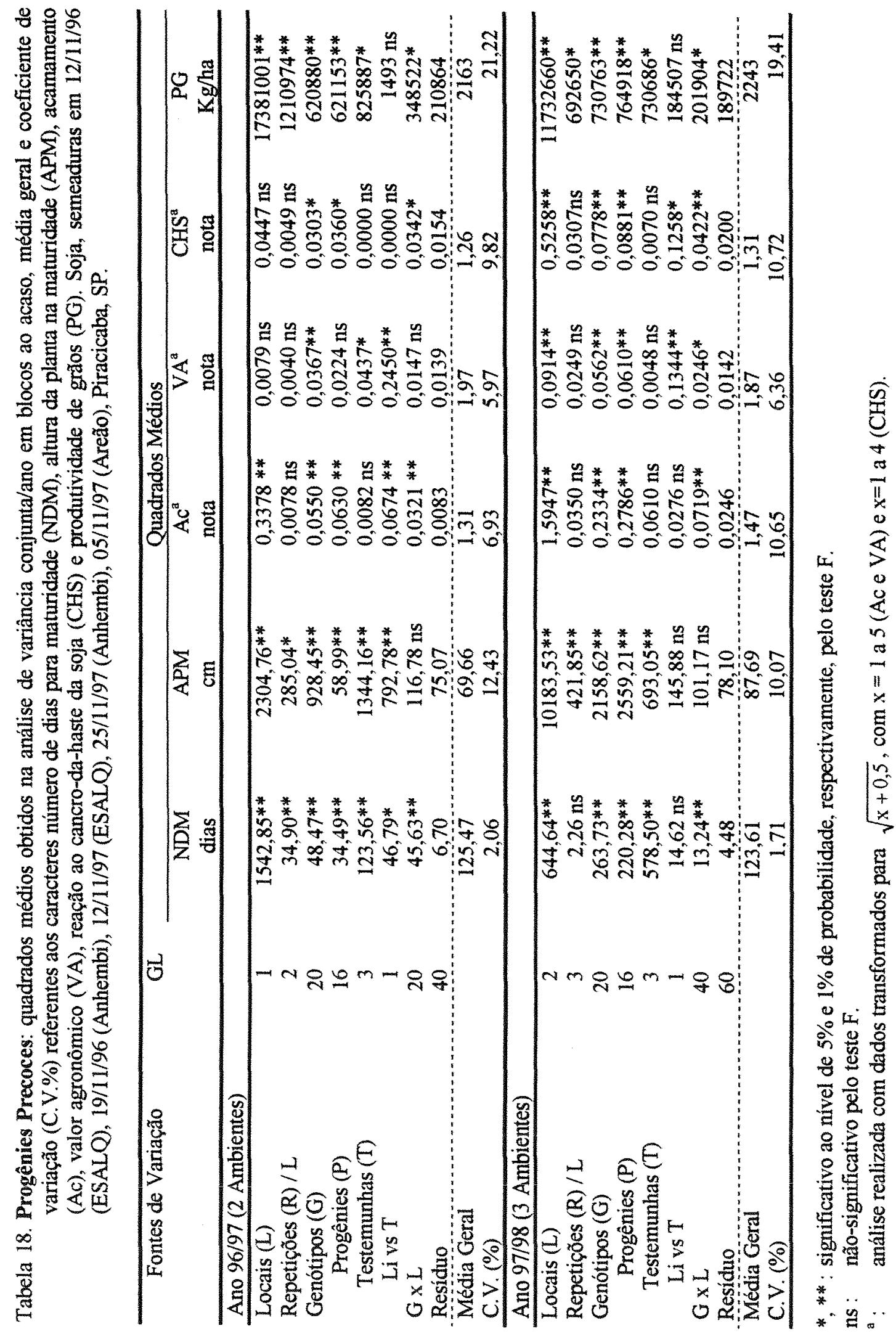




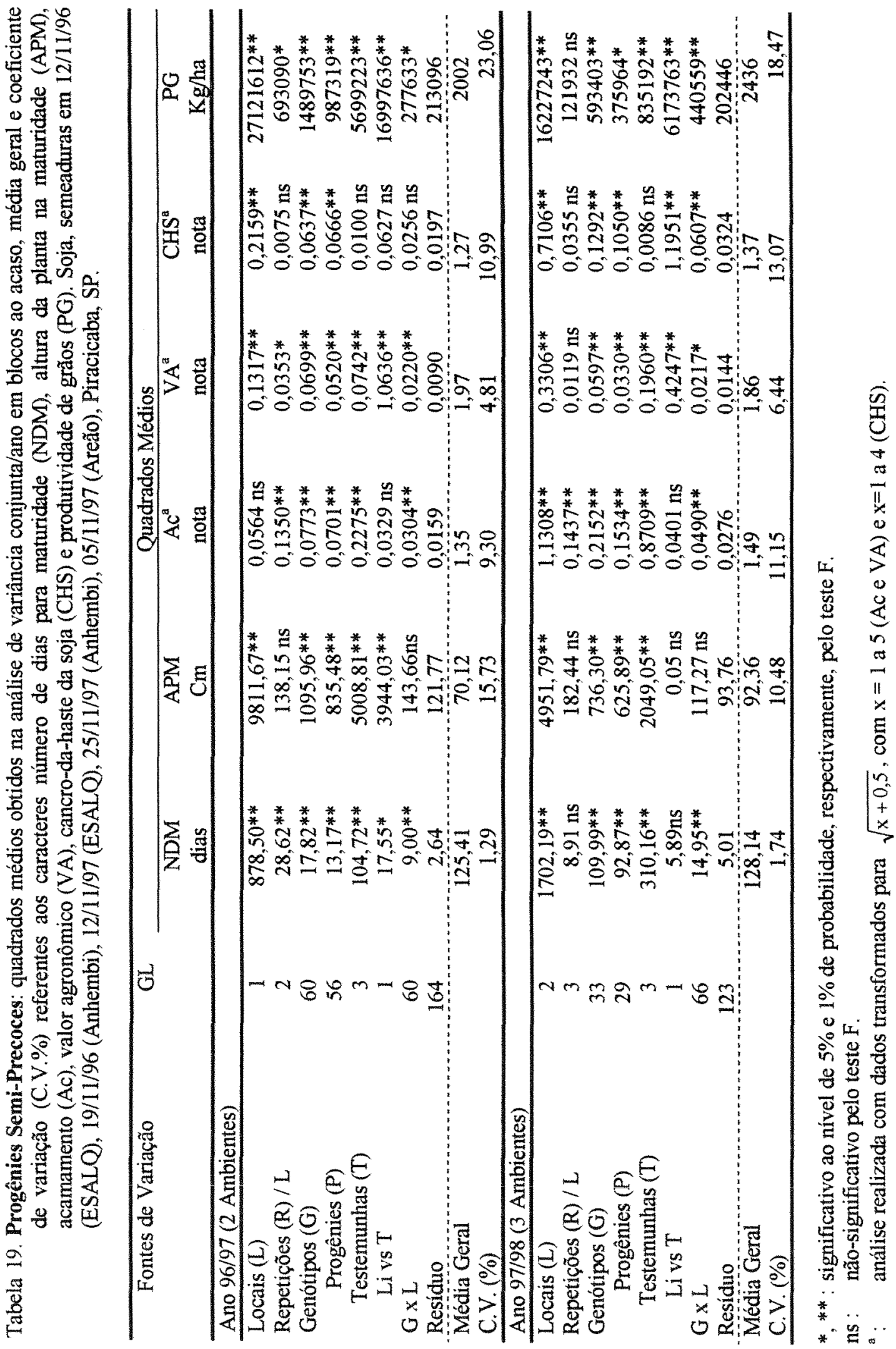




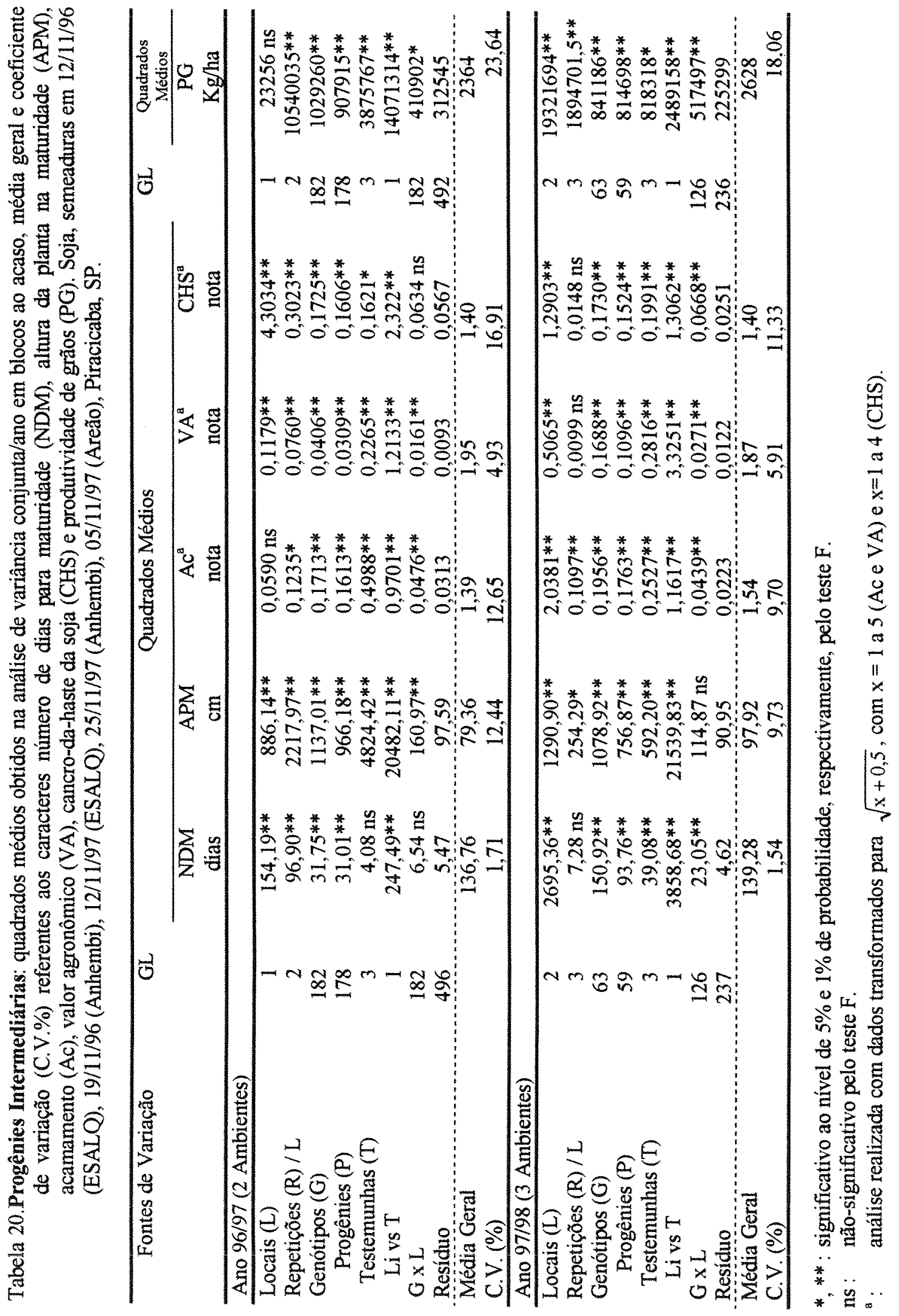




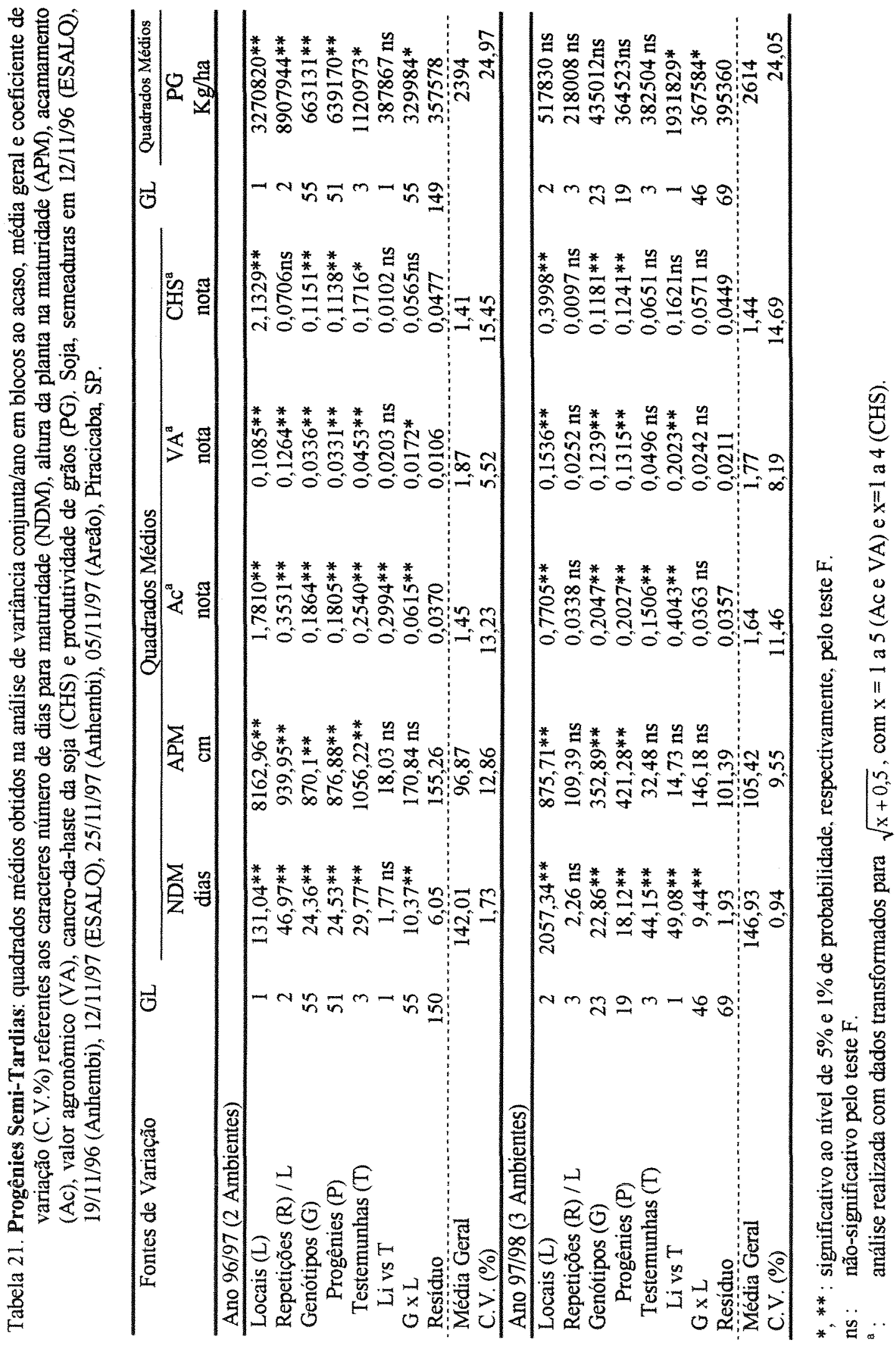




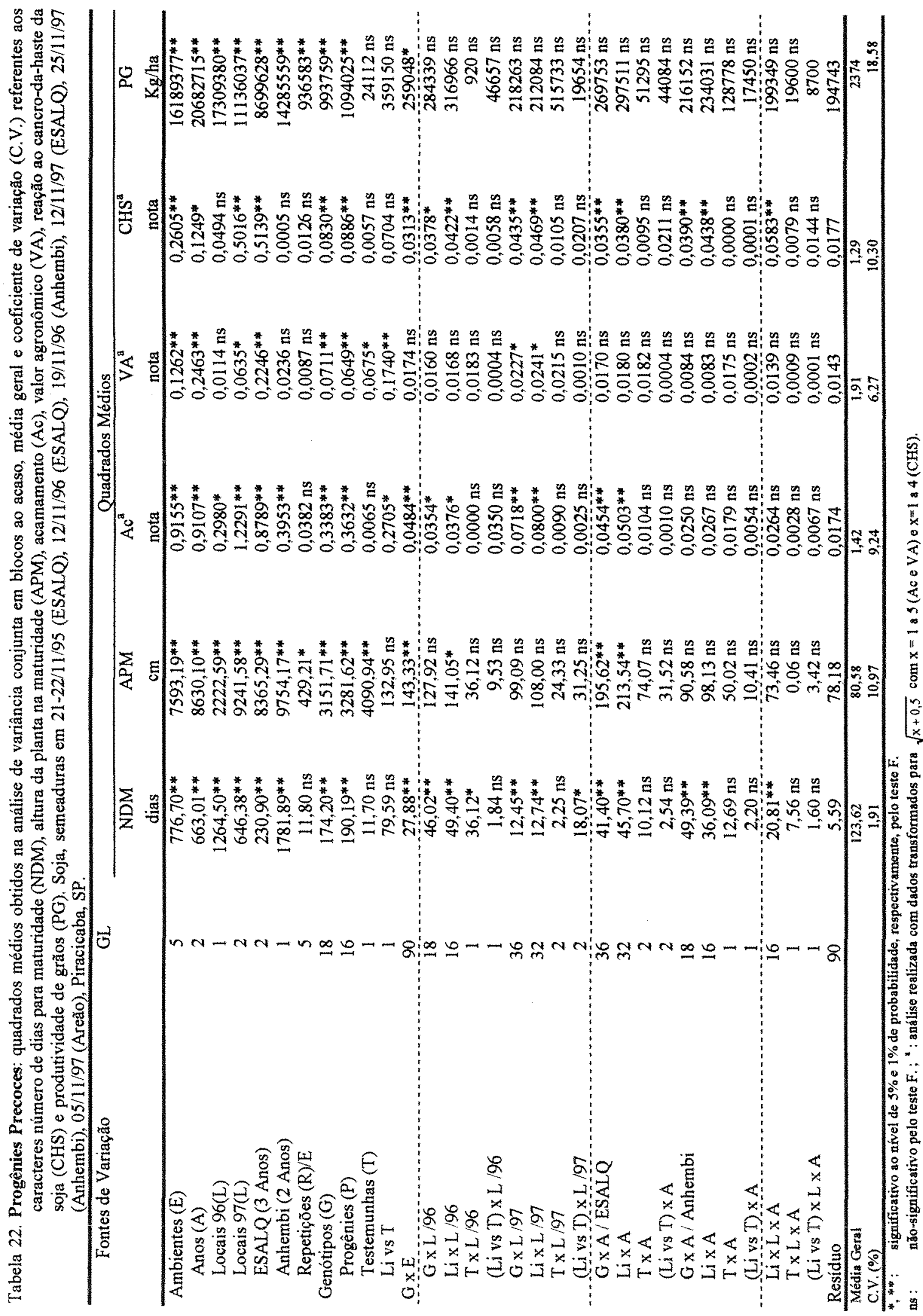




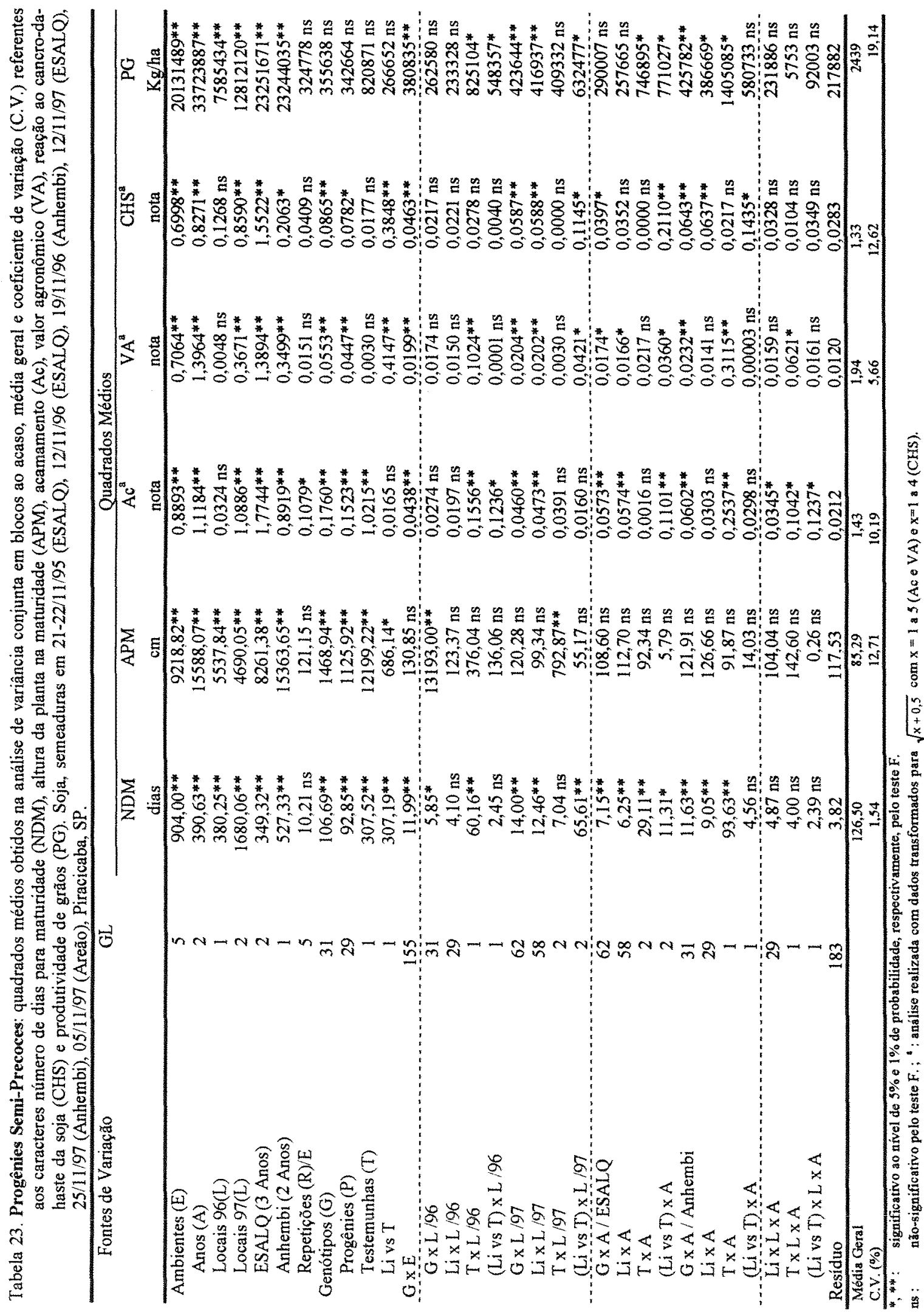




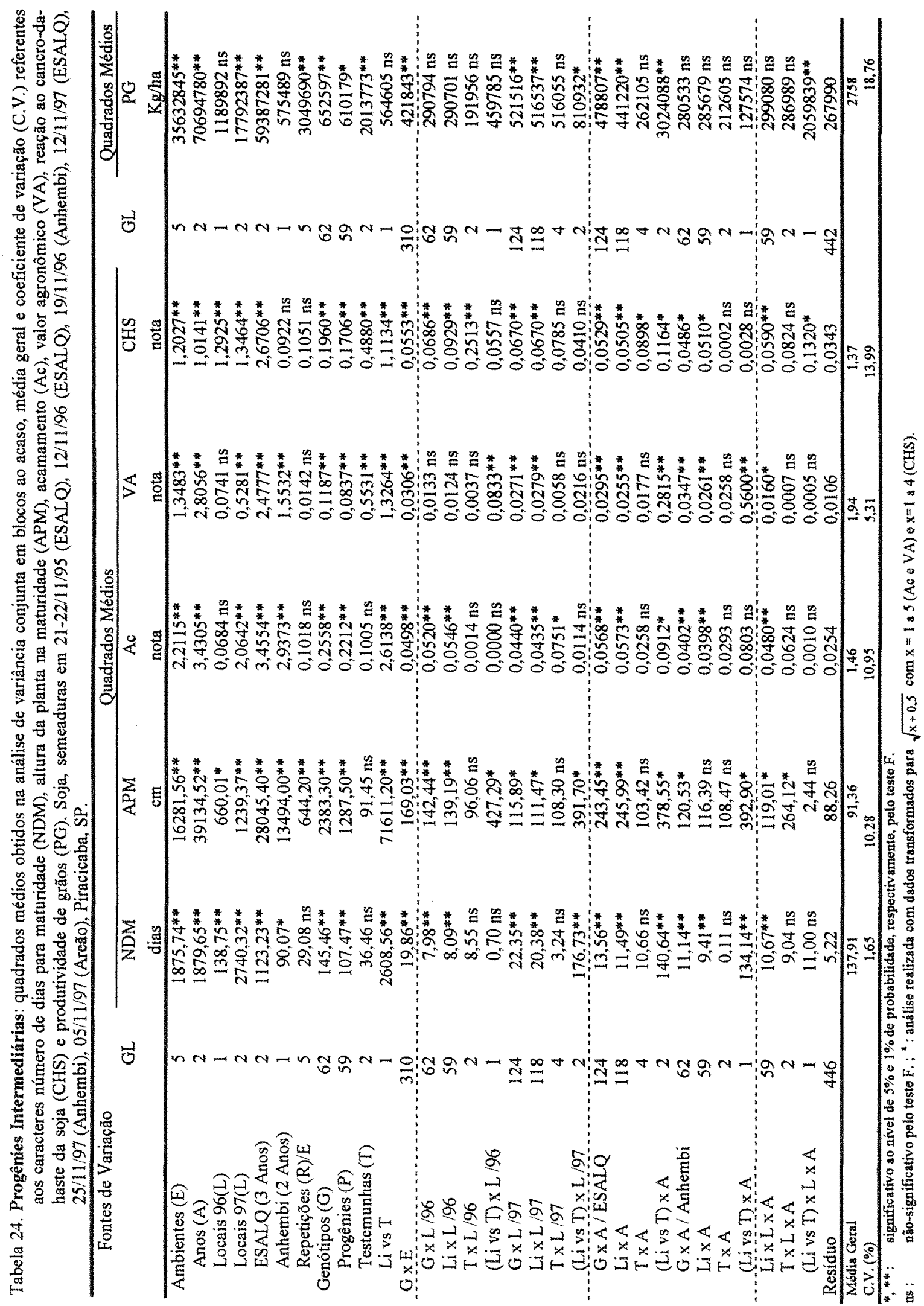




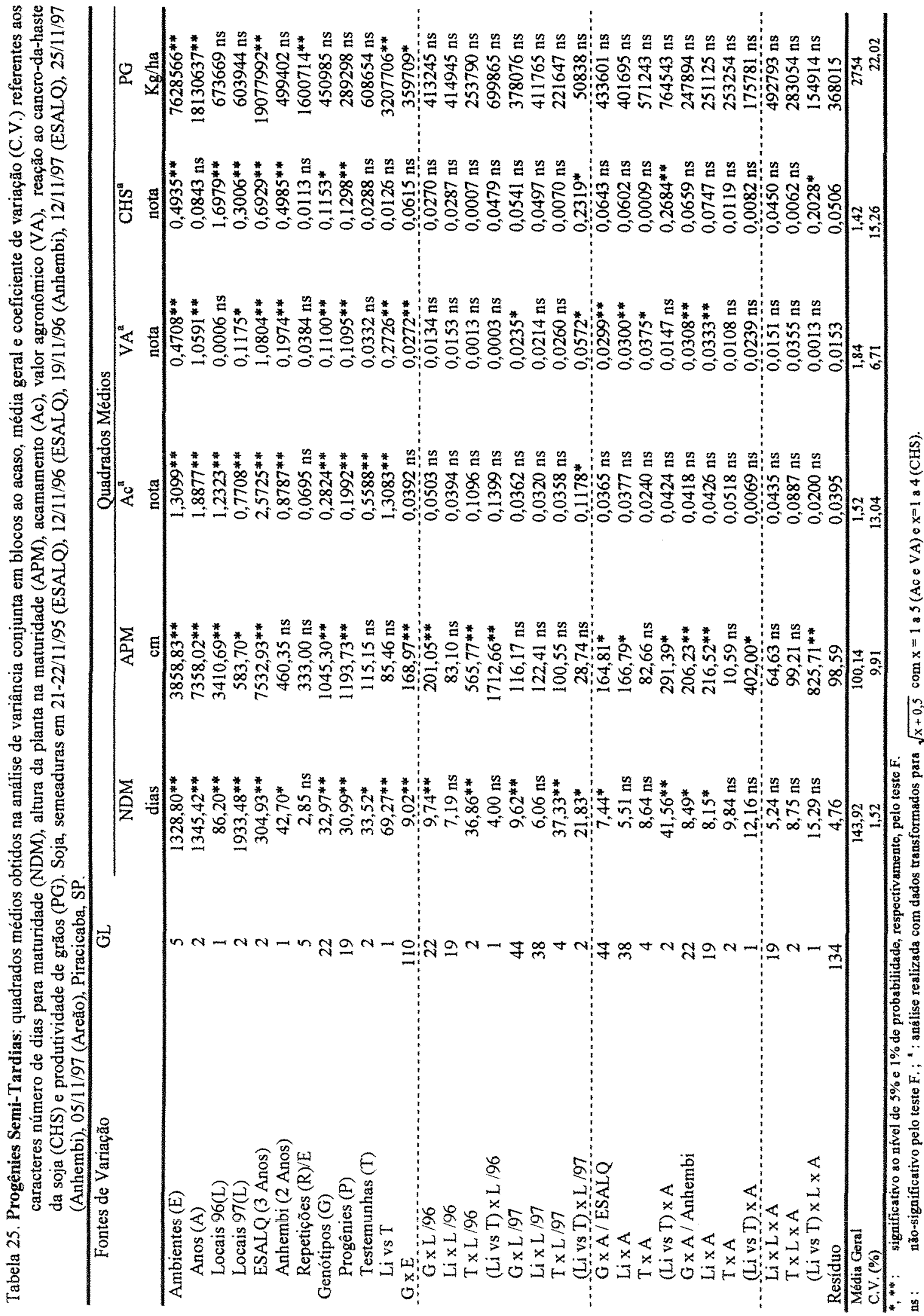




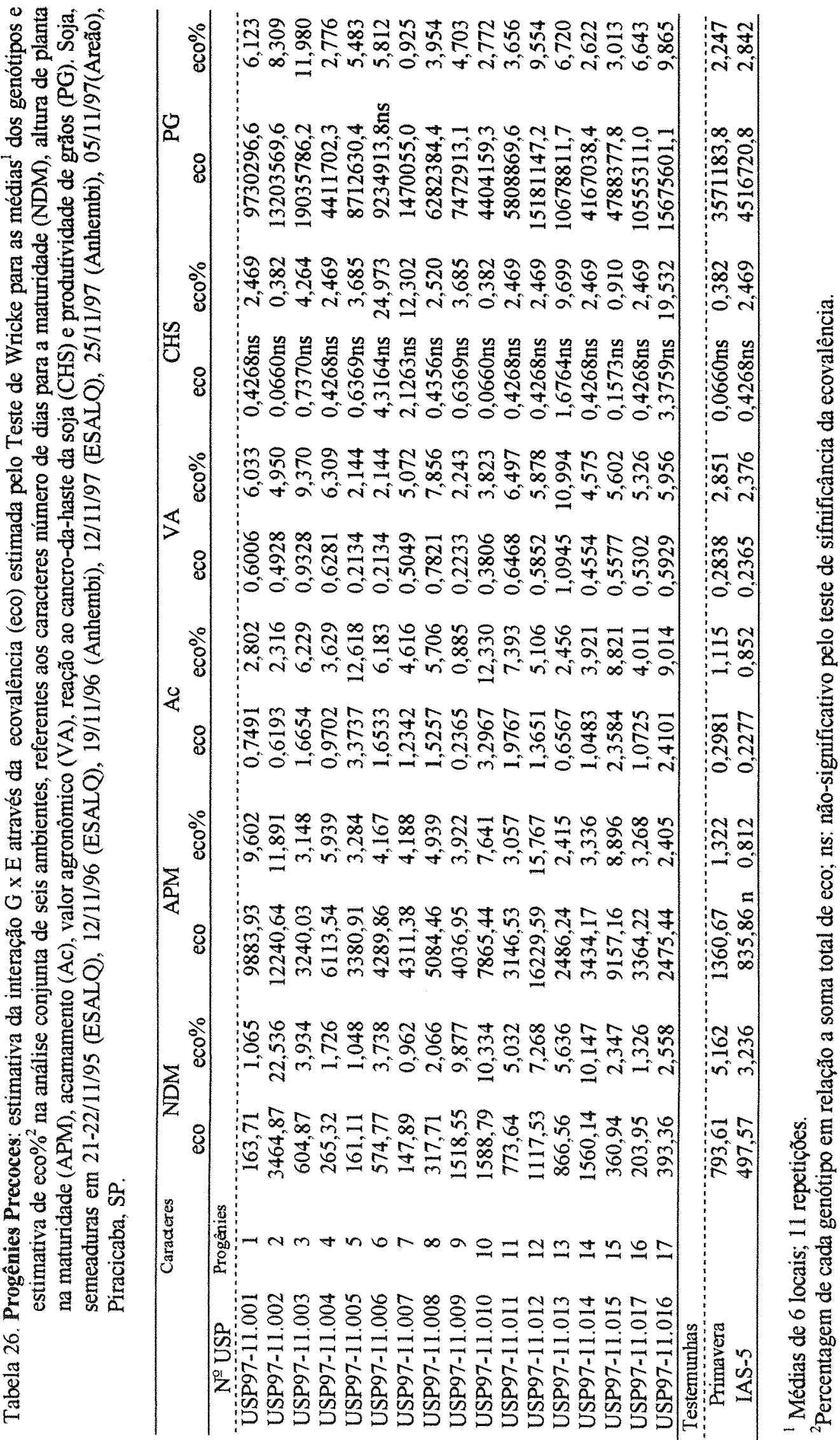




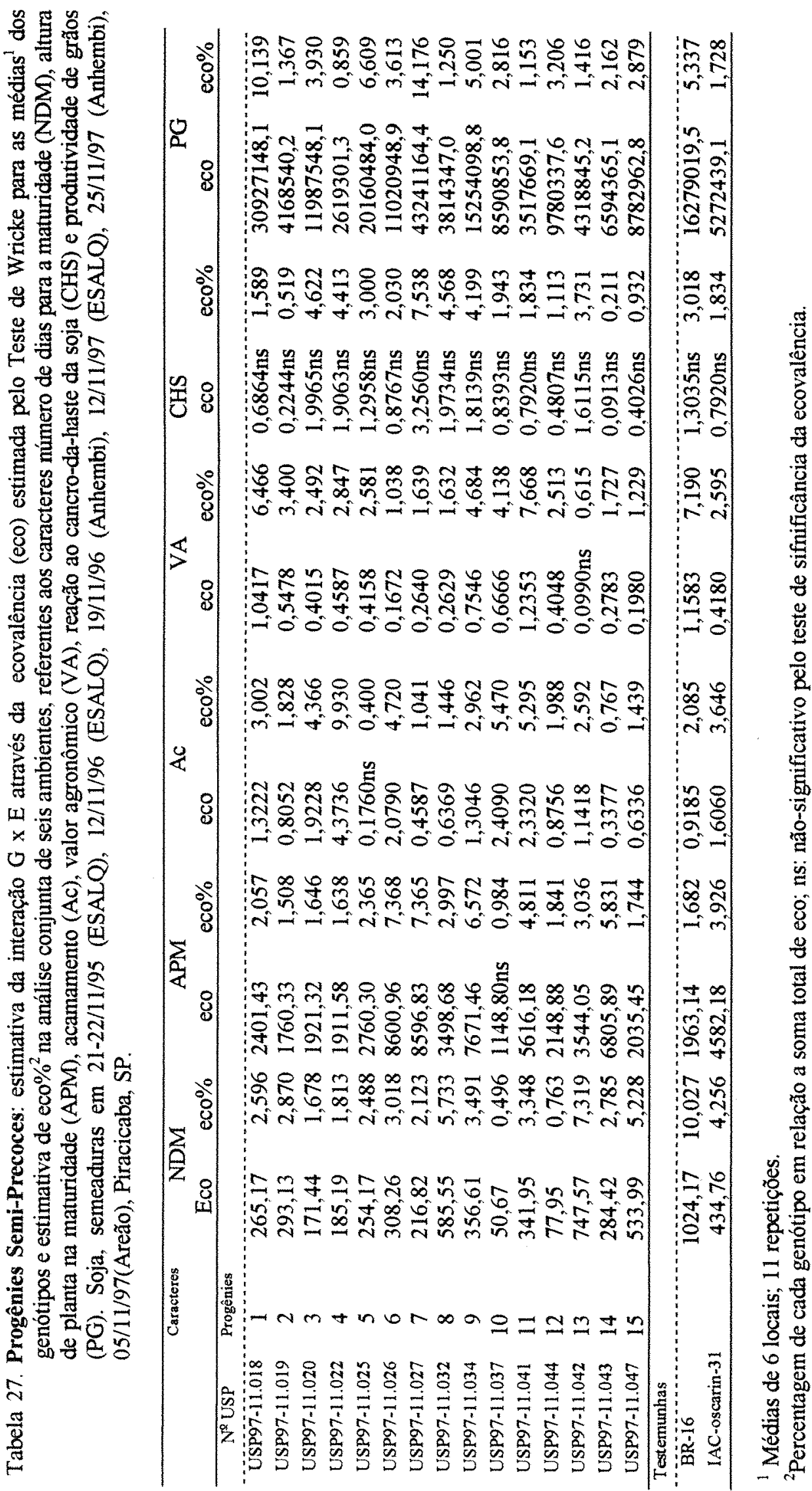




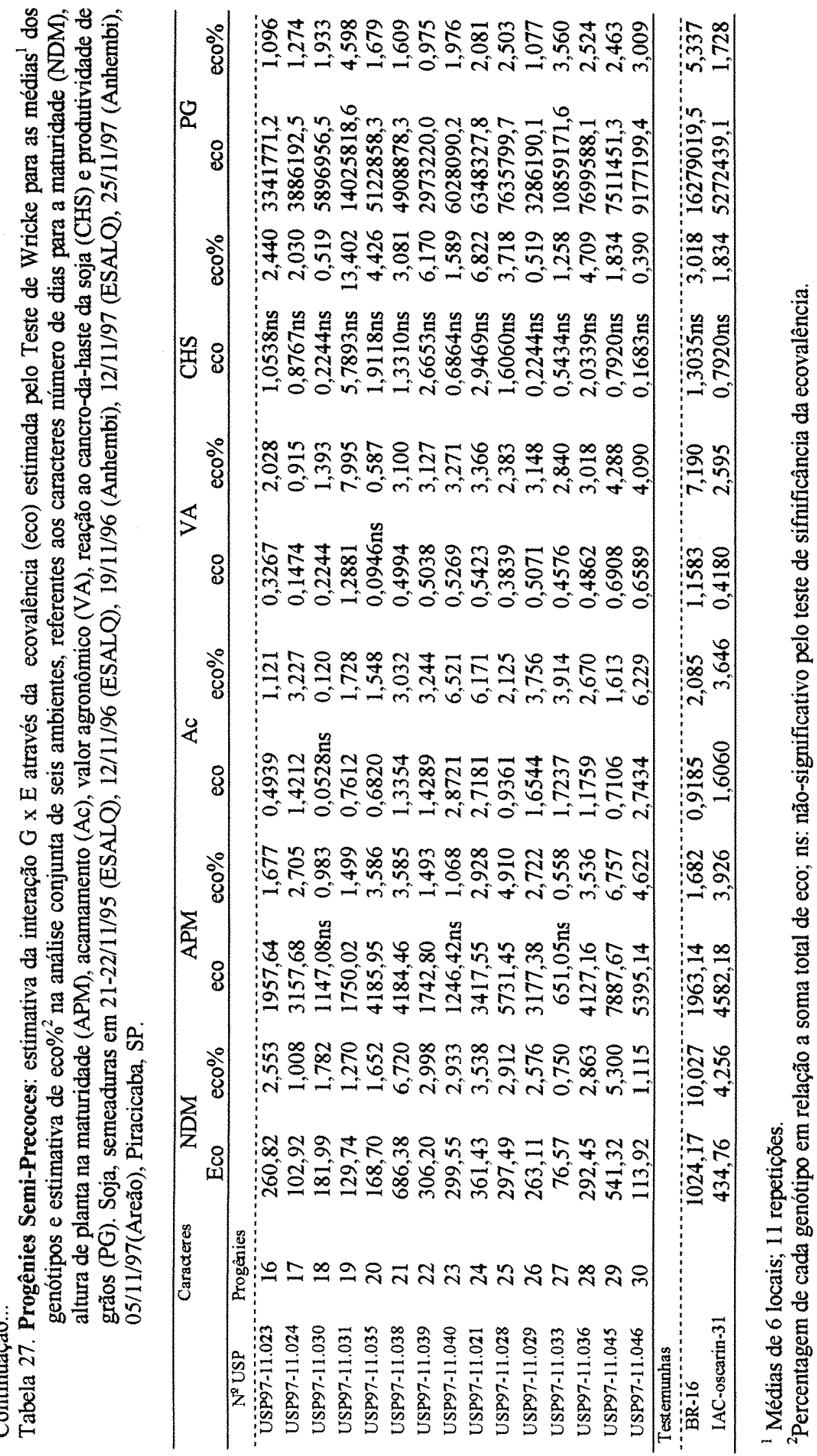




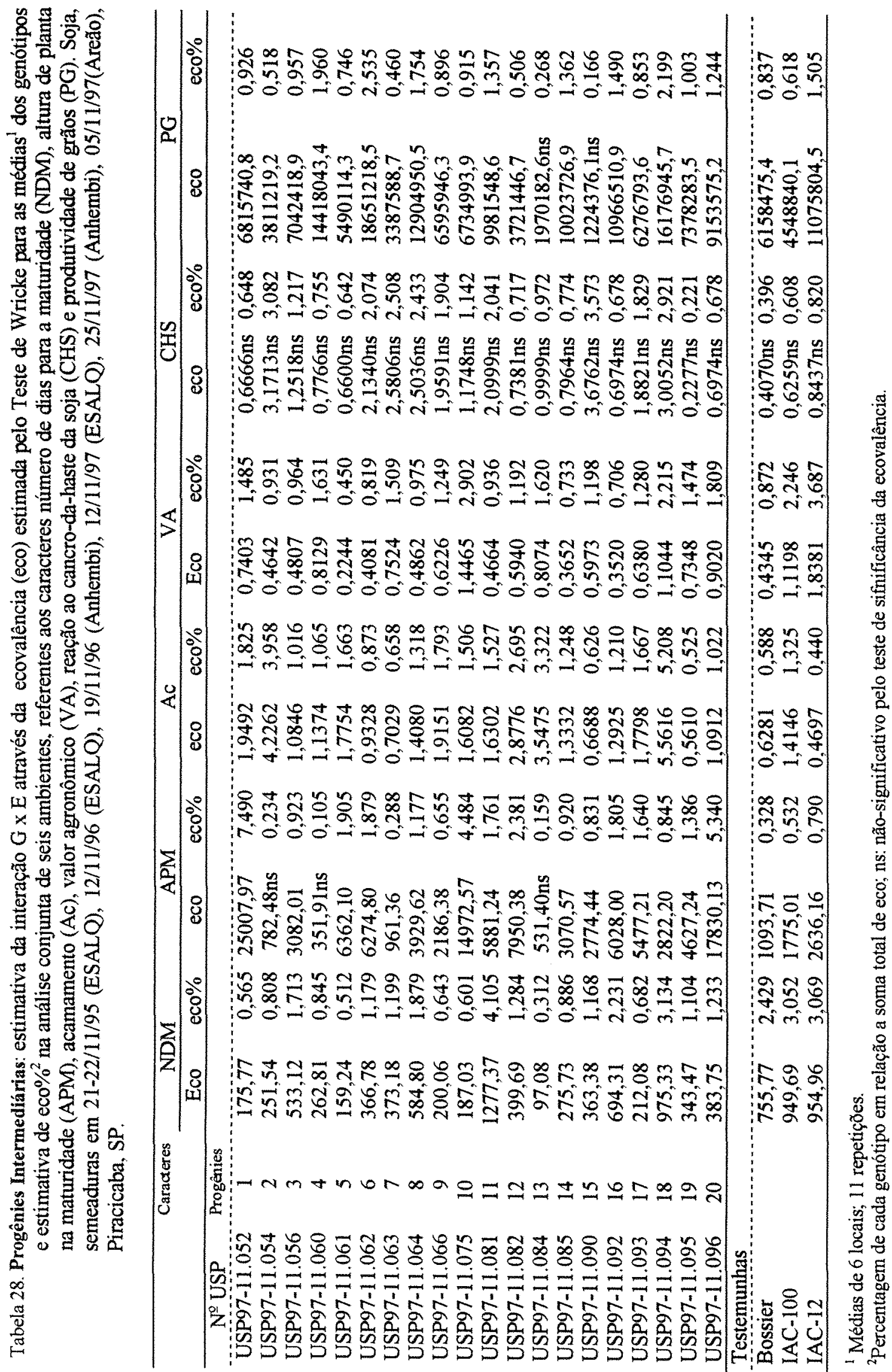




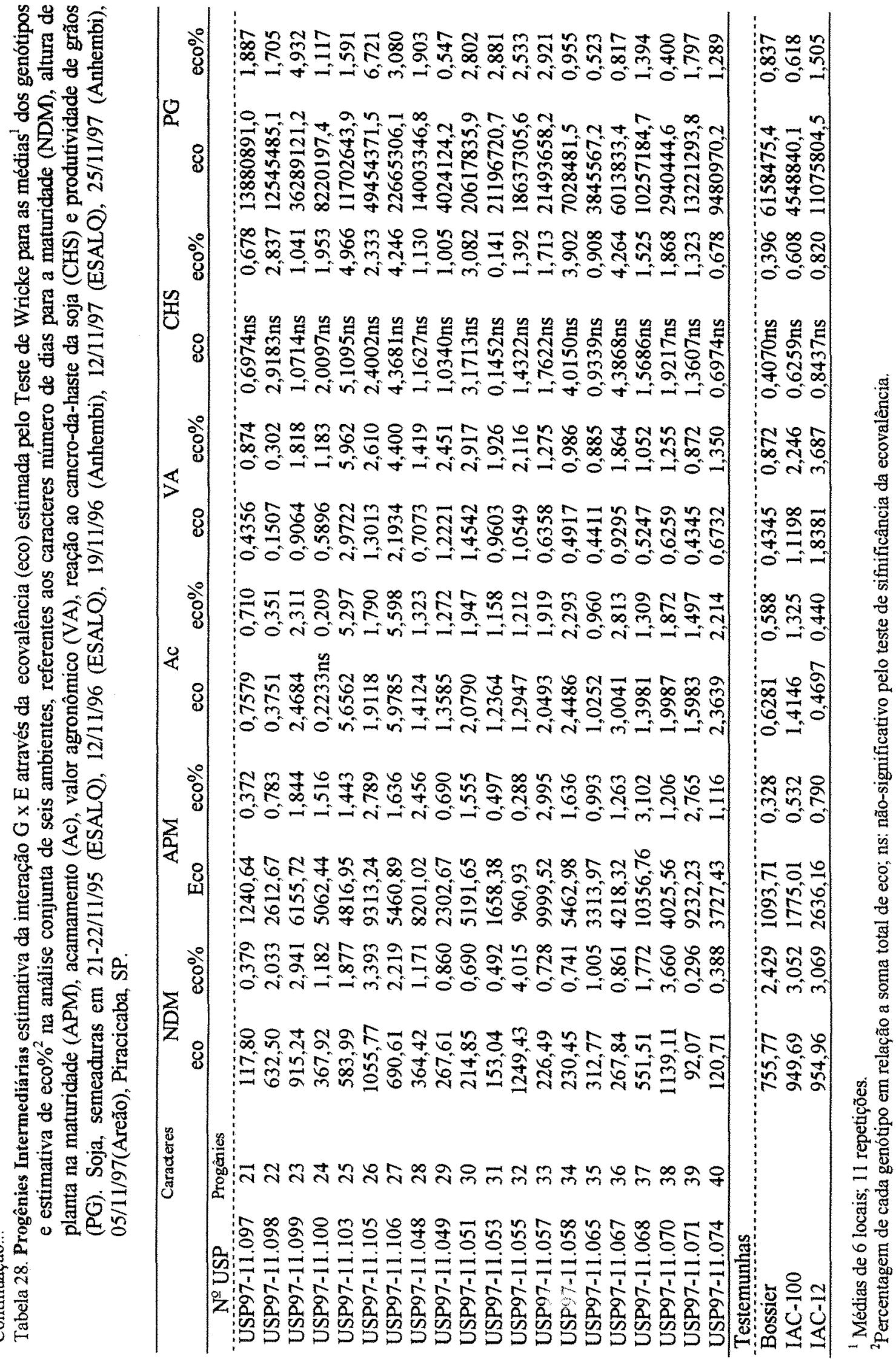




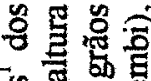
त क 要过 造过 的宗 定

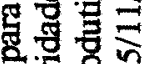
동 总帚。 평 的元

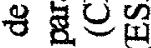
㺃 语㶽 음 옹온호 켤 를 灵宇 㝴 密壱 을 영 石 罡导品 过

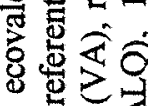
ज话 릴 递。 톨 네 옳 $\times$ 而 $\hat{\theta}$ 总焉过安 导司选 罗品

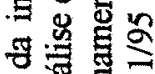
ए 를 氜 हूंते प्रें ह 용 물

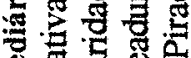
胥 를 总 焉总怘

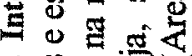
눙 路

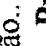
过告

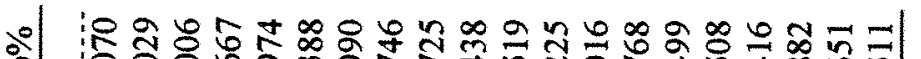

u

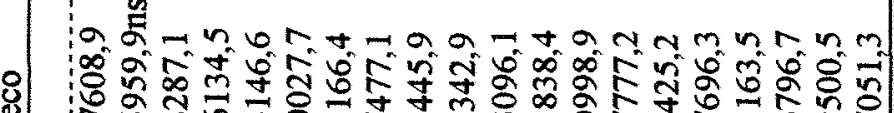

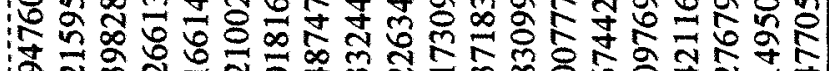

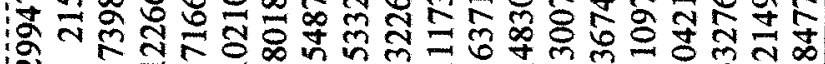

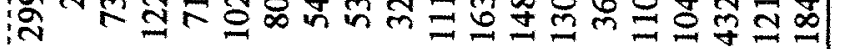

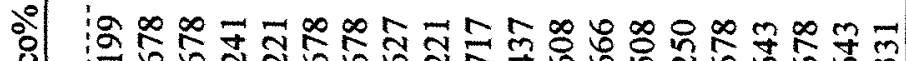

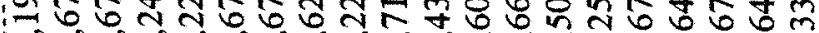
里

$\frac{2}{\mathrm{I}}$

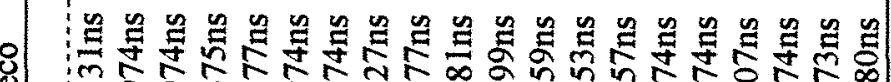

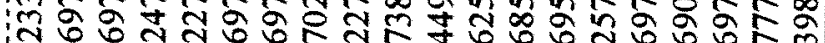

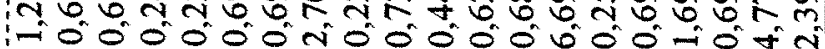

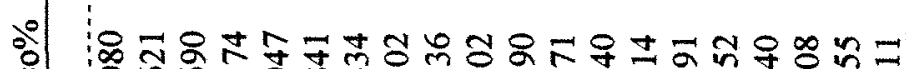

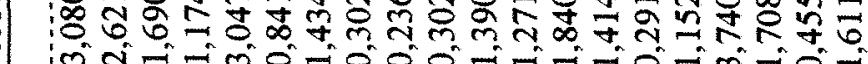

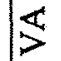

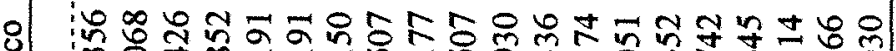

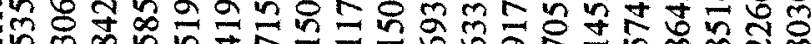

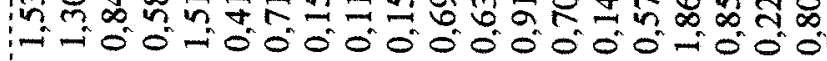

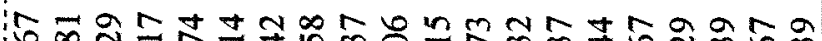
구의 \&

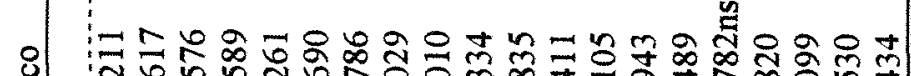

\&

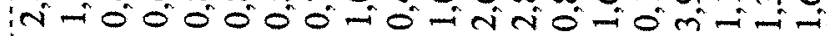

영

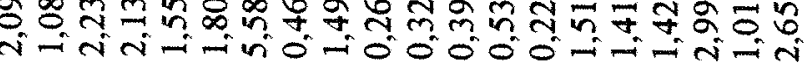
依

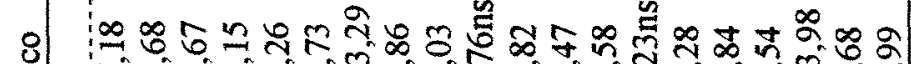

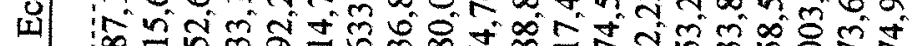

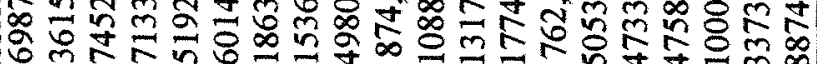

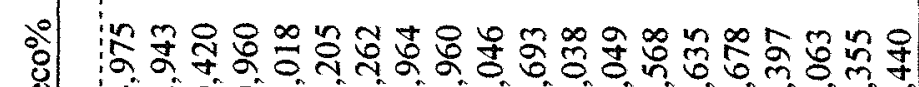

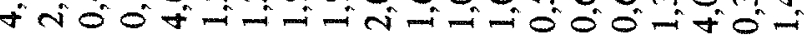

ช

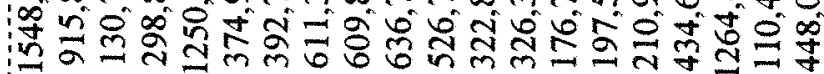

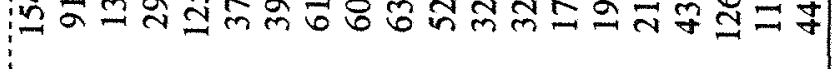
:

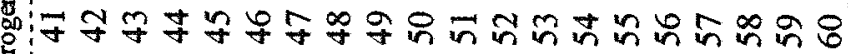
皮:

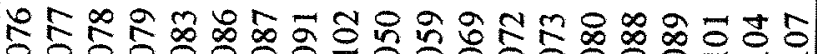

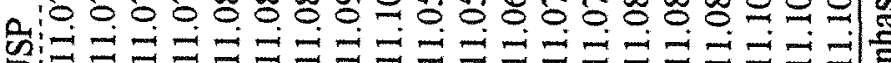

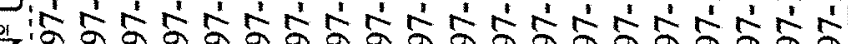

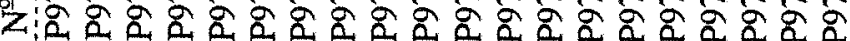

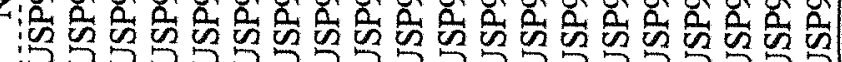

0

it $=n$

ñ

央央

เซ

요요 m. (1)

帘 ㄴํㅇ 0 ind

ㄴํㄴㅇㅠ 꿍

०त

in $\infty$

宓文

$=0$

我舟

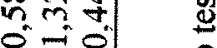

\&

象定

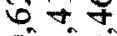

$0 \rightarrow 0$

뚕ㅇ

m n

:00

주은

mine

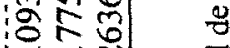

영

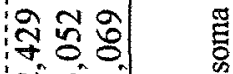

造

i下 62

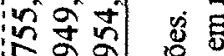

这兑

-

解焉

:

드

용

驾焉

常总 


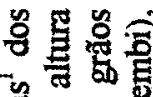

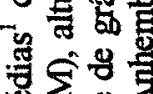

㟧导

己贾

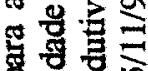

을

氖寻宫

政

些出

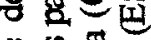

芺喜莺人

4 의

을 윤 농

沓灵富

है

氙产

옹

造

昰焉焉

焉文官

运专

象总这

\%

흡융

壱

山.

$\times$ 뭉

0 o

焉要安

蛋

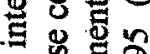

ง

क

文鸟

象穴官

预号要

可鸟哥

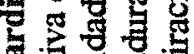

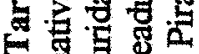

具苞官

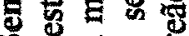

น

\&

불 을

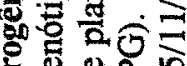

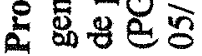

ते

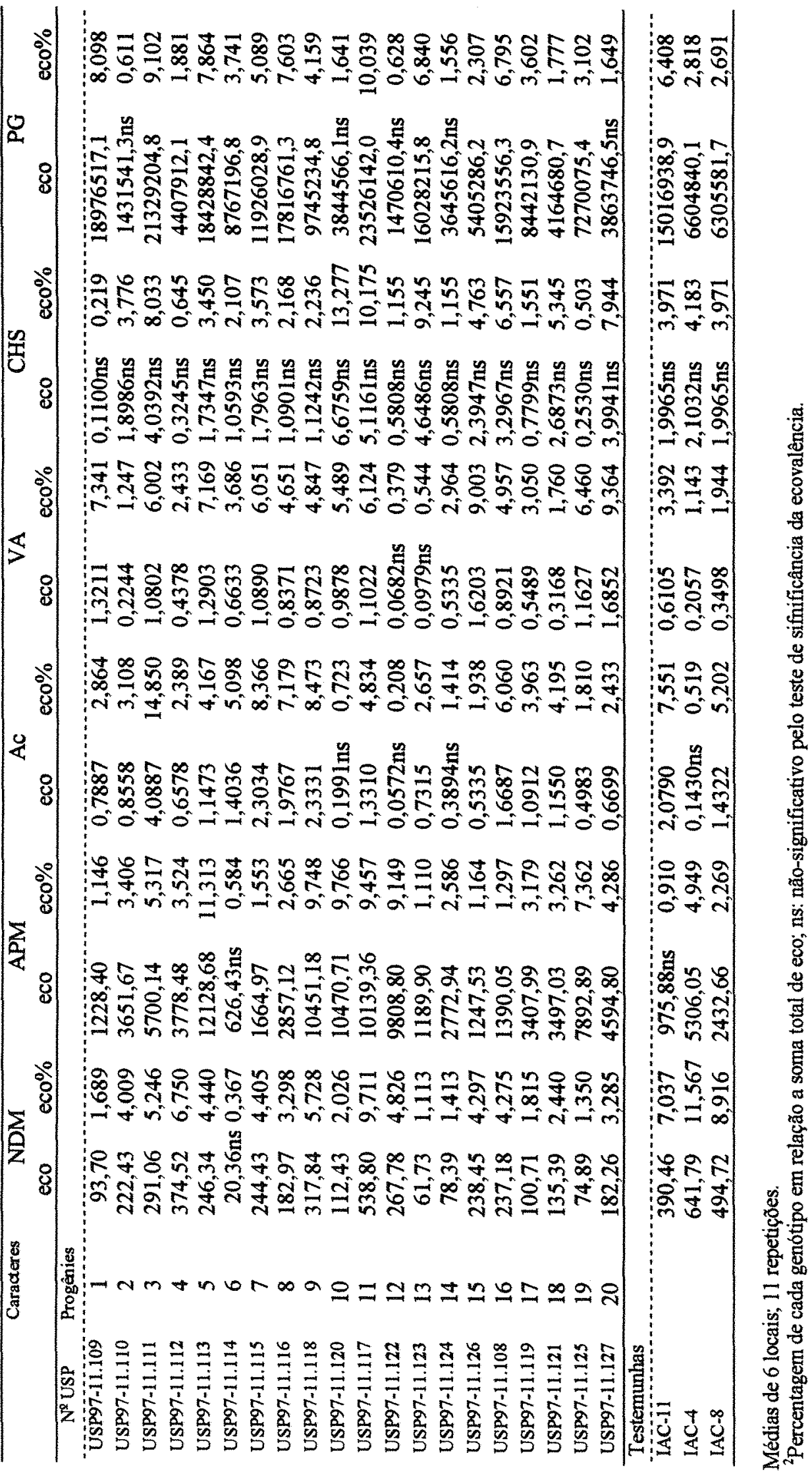




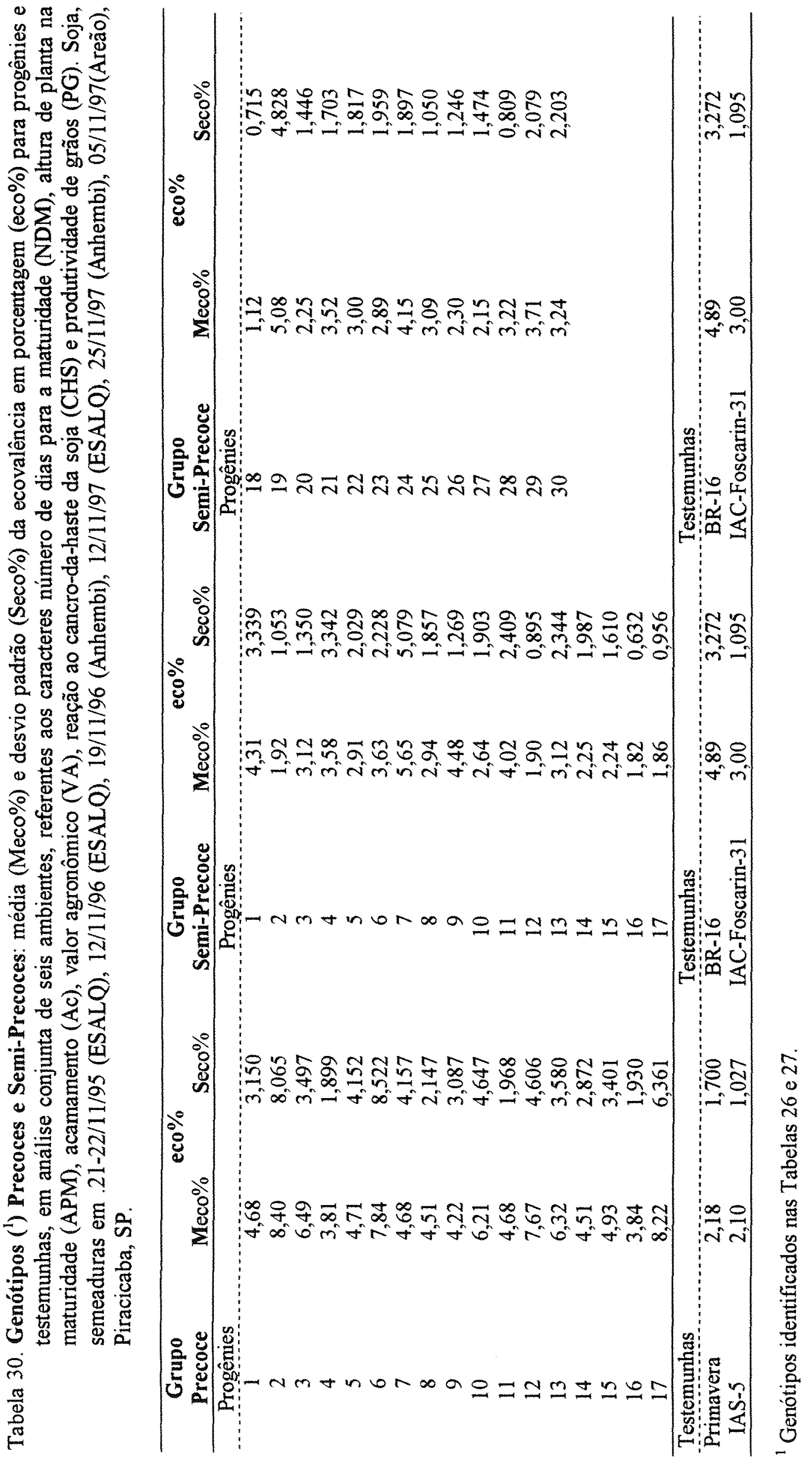




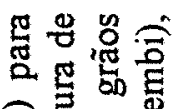
จ로욜 总定 $\sum$ 吾 은. 总 『응 $\$$ 家 氙 志芯 造㰴 त. ㅇํㅇ 8 웜

궁응 임은 8 口 융유 녕일 ㄷ. 영 으 용 연 岁完 룰 - $5 已$ (2) ㅇํㄹ

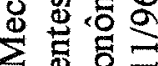
흘 뜸 in

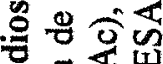
도콤용 ह

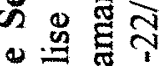
ह

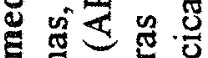
क 푱 - 范导。 \$ \%

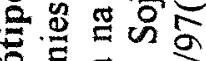

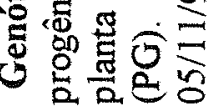
के 蛋 을 혼 홍

娄 政过 \& 范 공

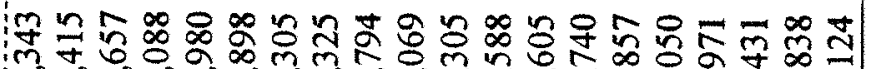

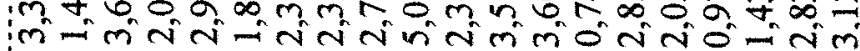

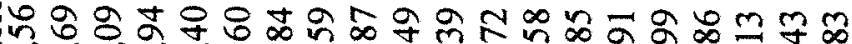

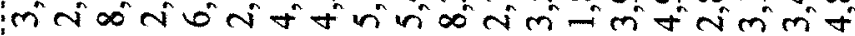

प्रm

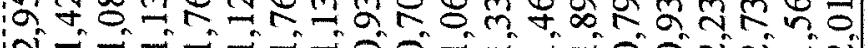

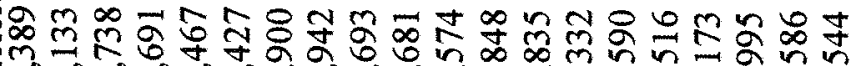

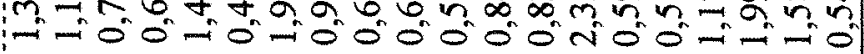

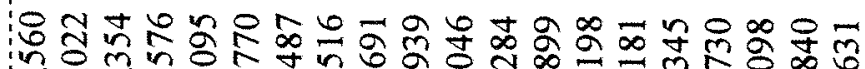

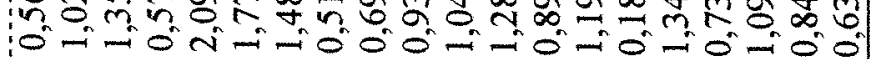
ㅇํㅇ

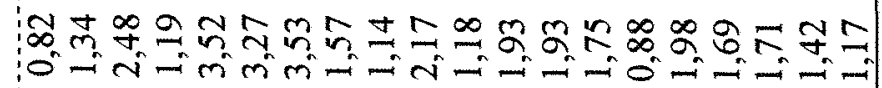
영요 $\sum$ 욜

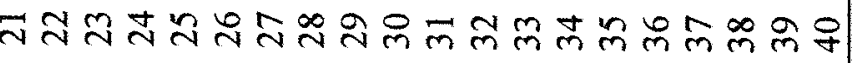

iot

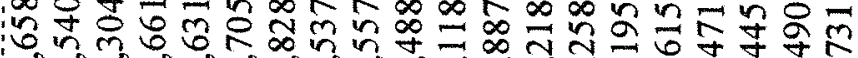

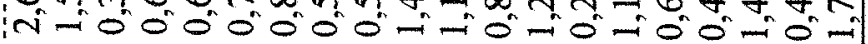

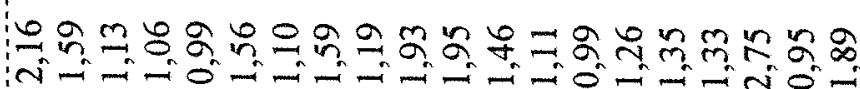
ing 声齐 $0=$ 을

융 inmin 188 


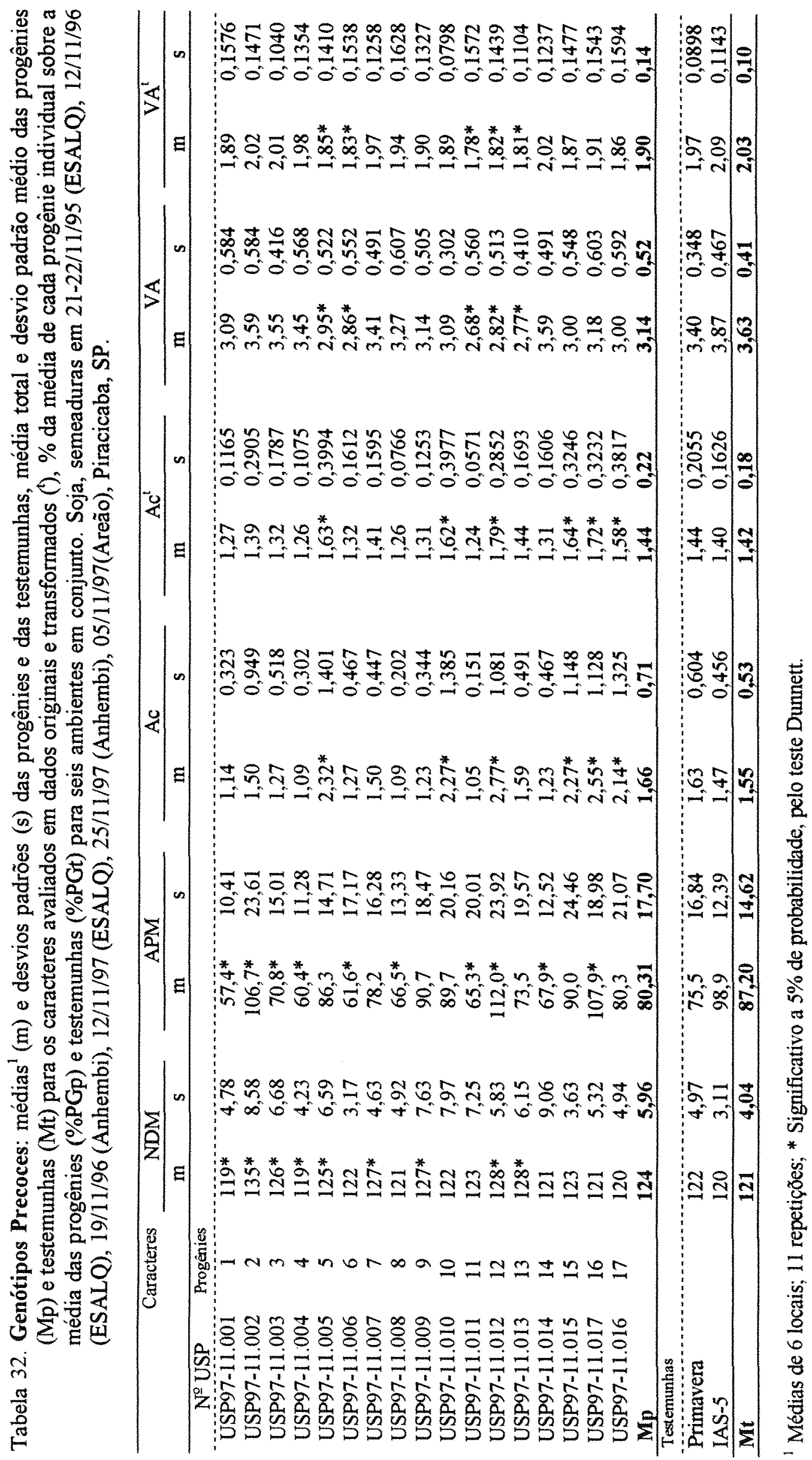




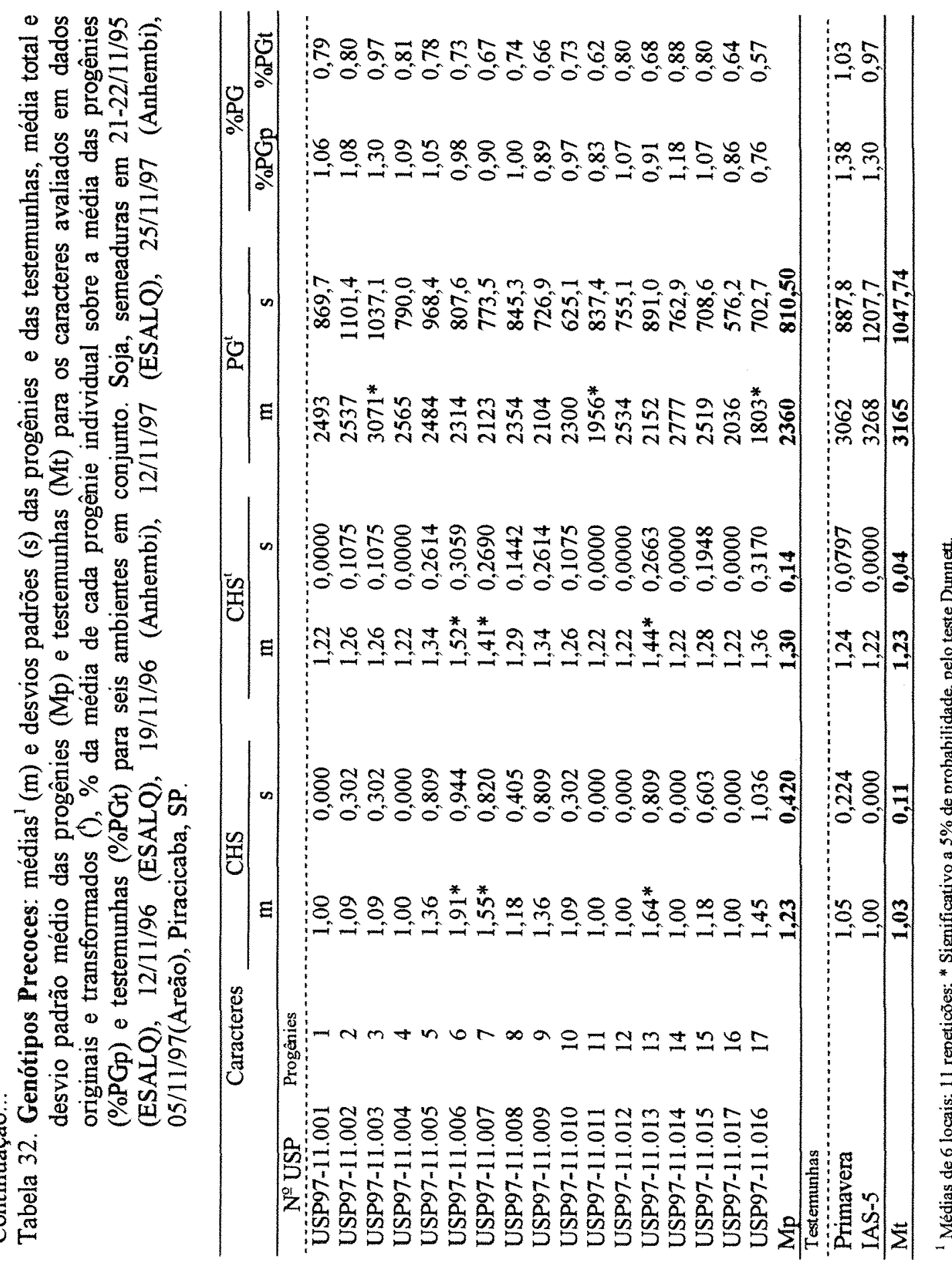




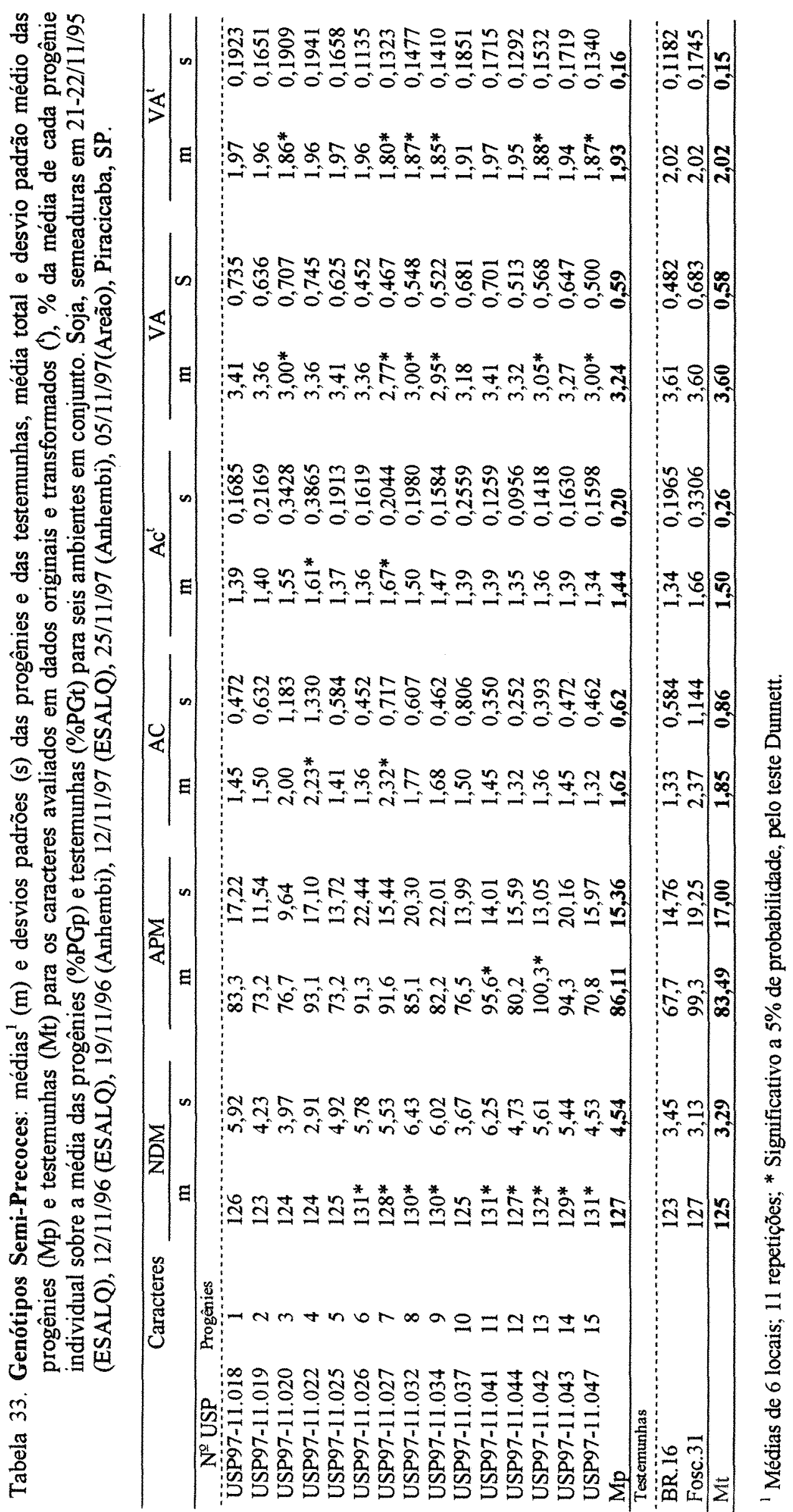




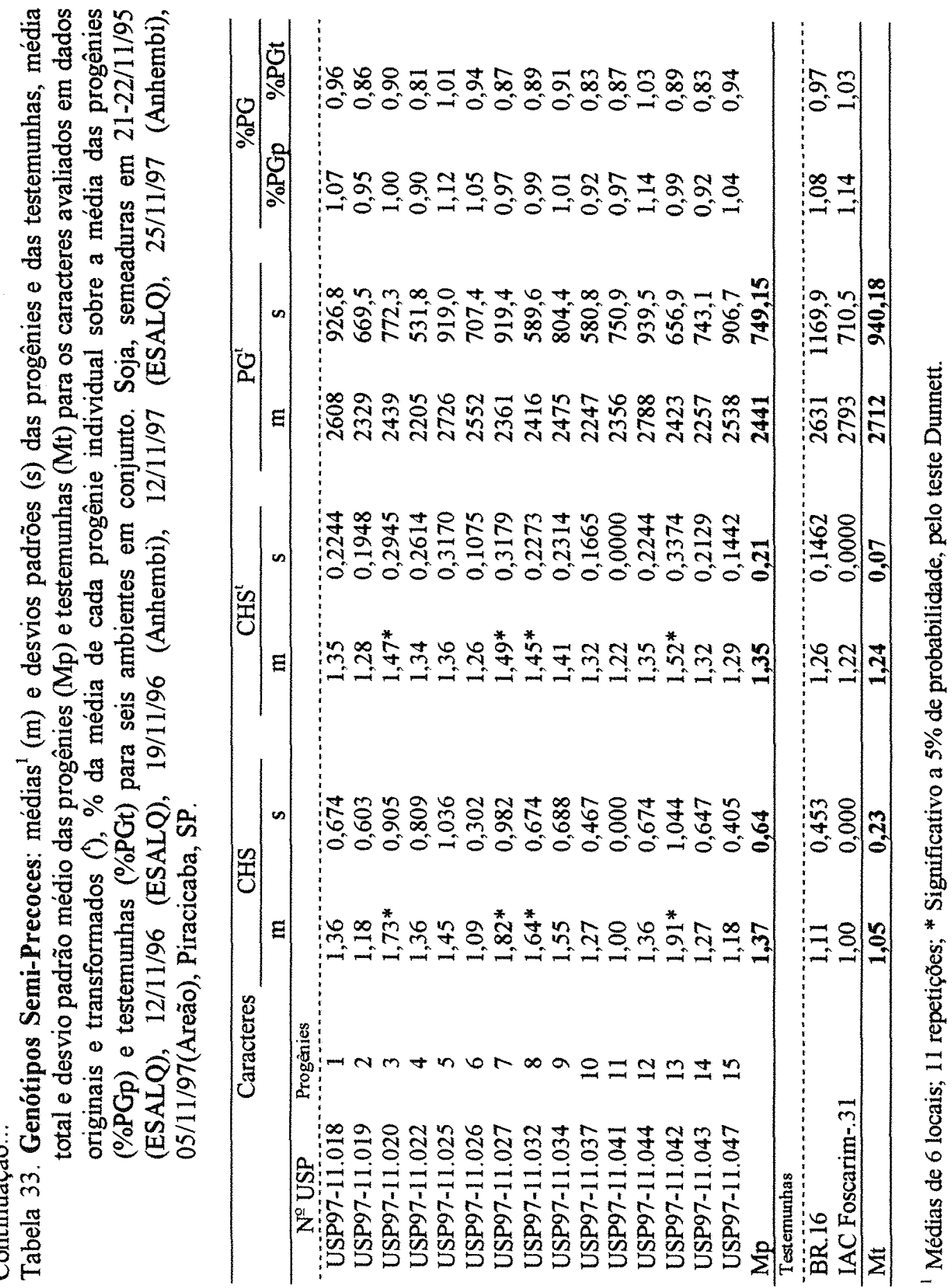




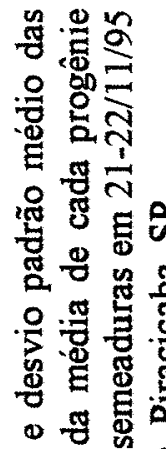

종

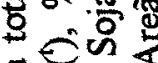

刍

惫总䒿

ข

要 80

灵䒓宅

范岁

苞。芶焉

次瓷廷

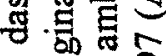

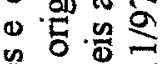

o

㐘哭 出

政要

के

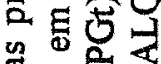

ㅎํㅇ융

(n)

范主

。

鸟

尺.

艺出

远

范

๒

응

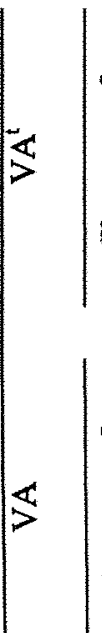

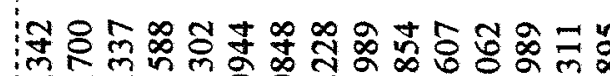

- 근

染

ic 0 की

a

a

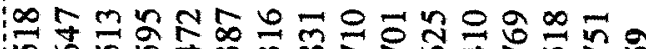

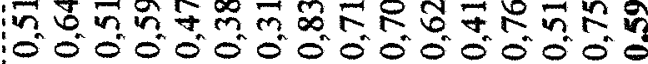

î

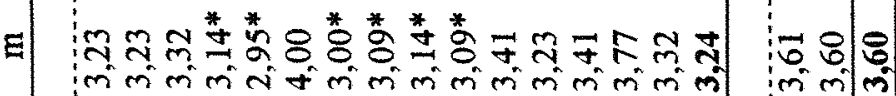

m

$\&$

E

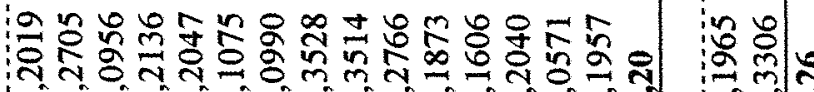

ơं

ฉ.

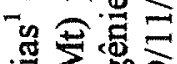

चैं

吃

$\ddot{\partial}$

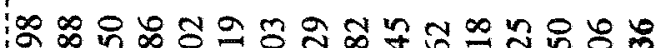

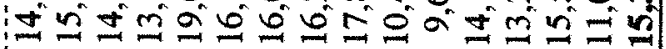

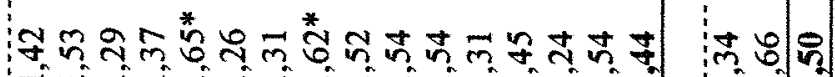

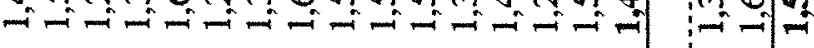

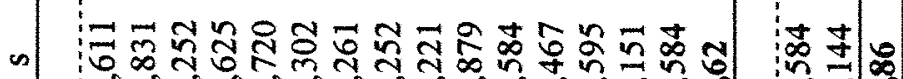

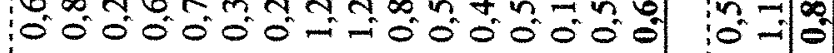

E

槣

inn $n$

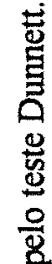

月

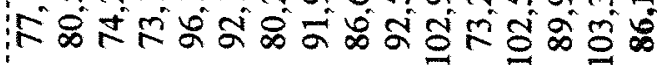

i⿻

iे

in $m$

iิ

ï

8

E

要艺出

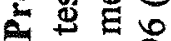

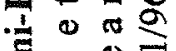

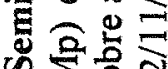

फ $\sum^{2} 0$

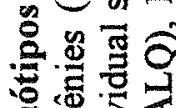

खृ

吉. 巴

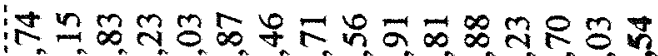

in $=2$

जि से की

लिं लेखें

छ

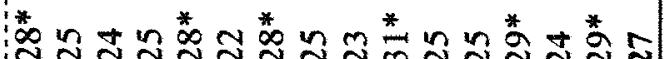

约 든

造

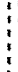

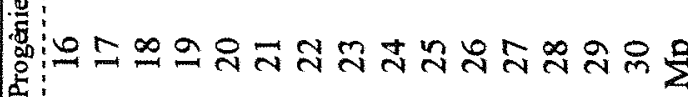
:

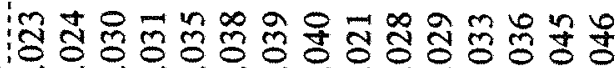

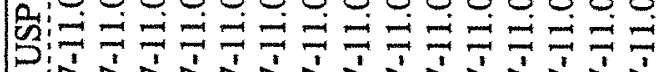

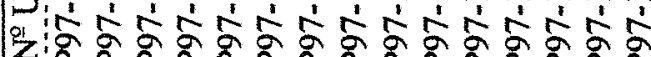

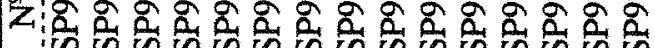

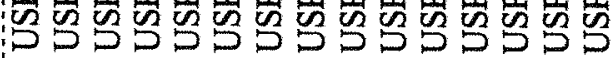

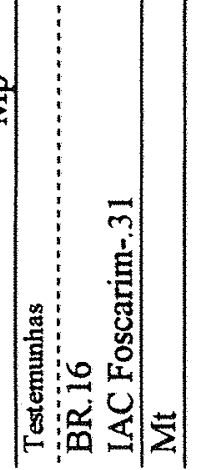

通

$\exists$

?

造 


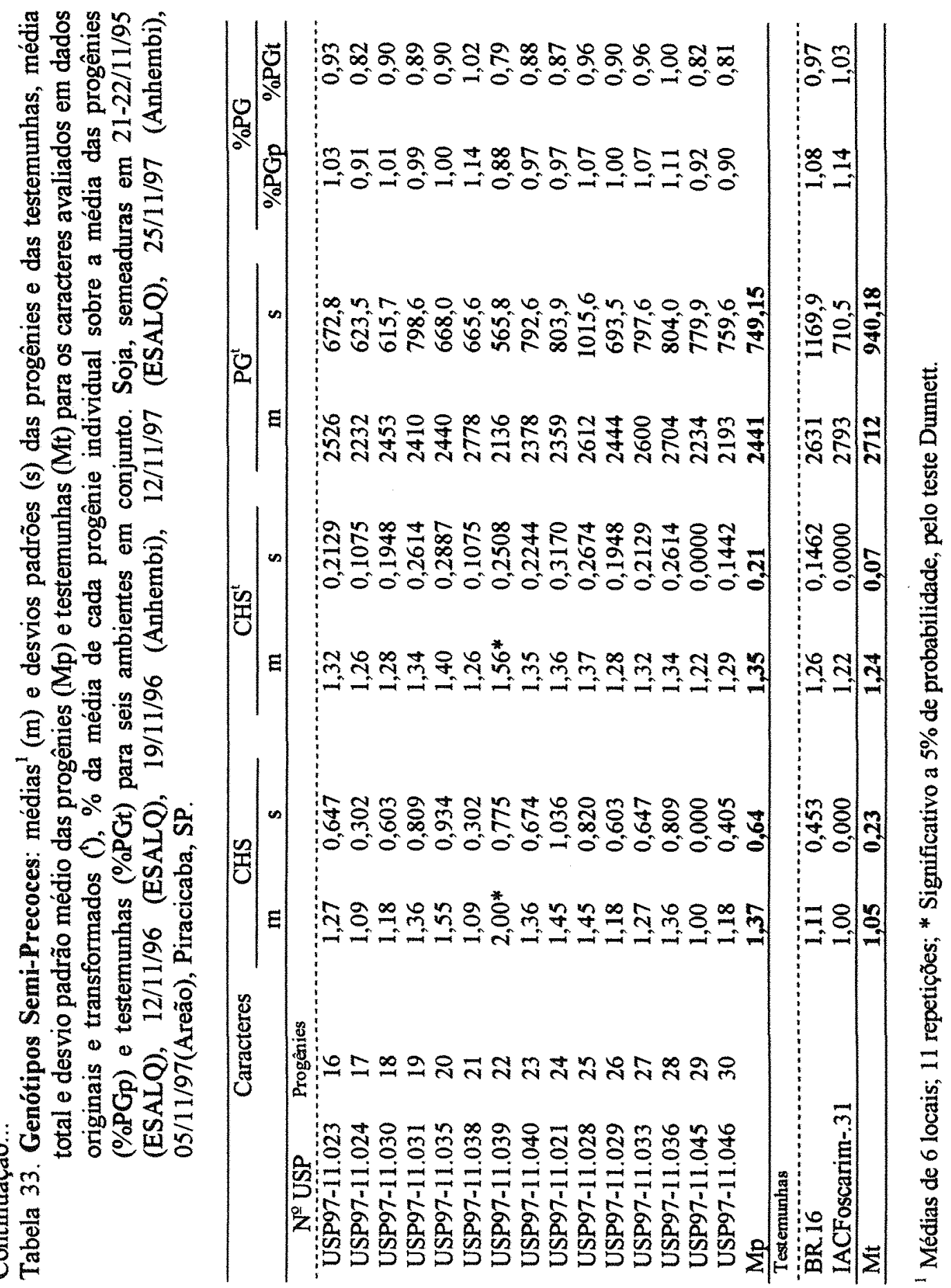




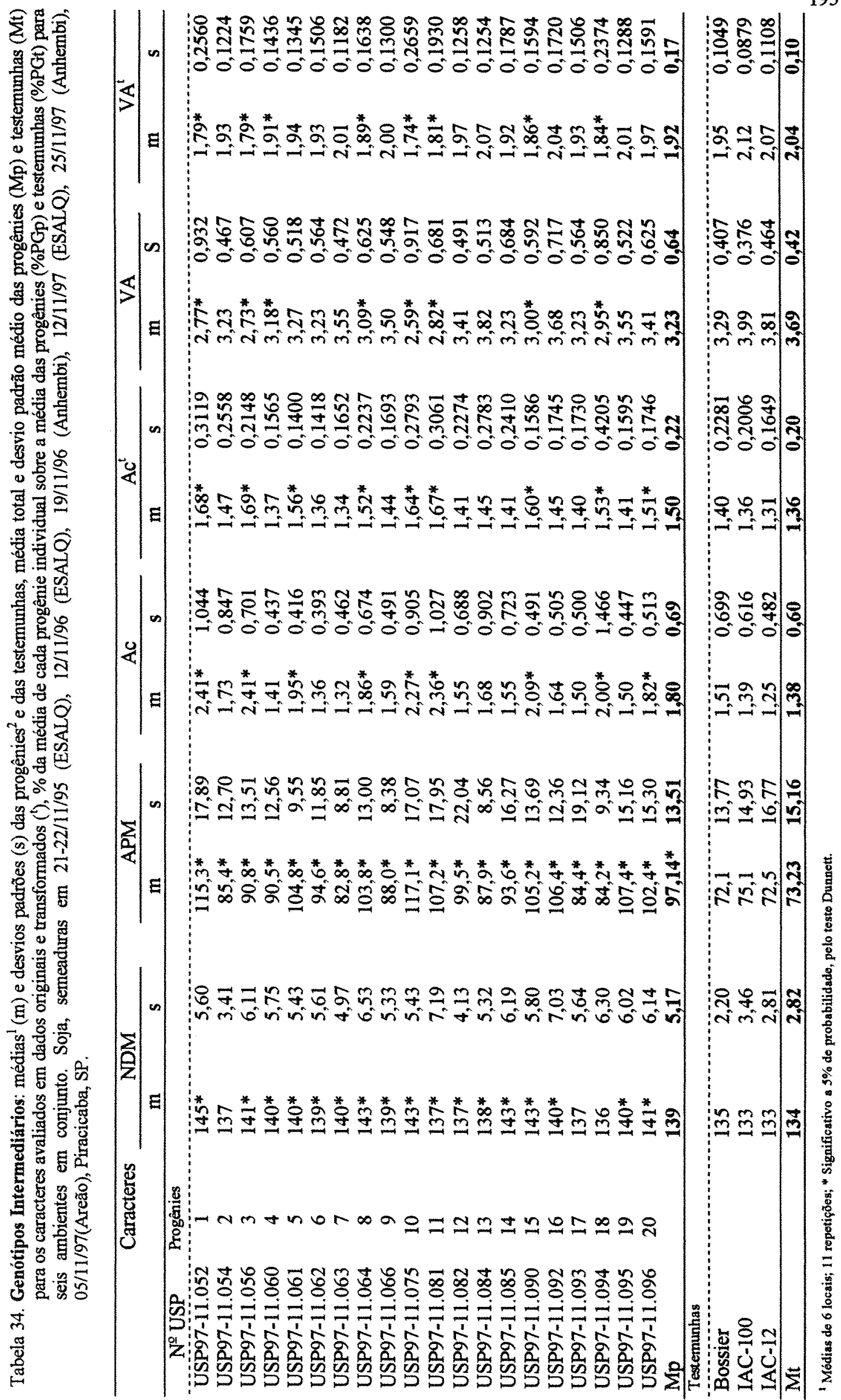




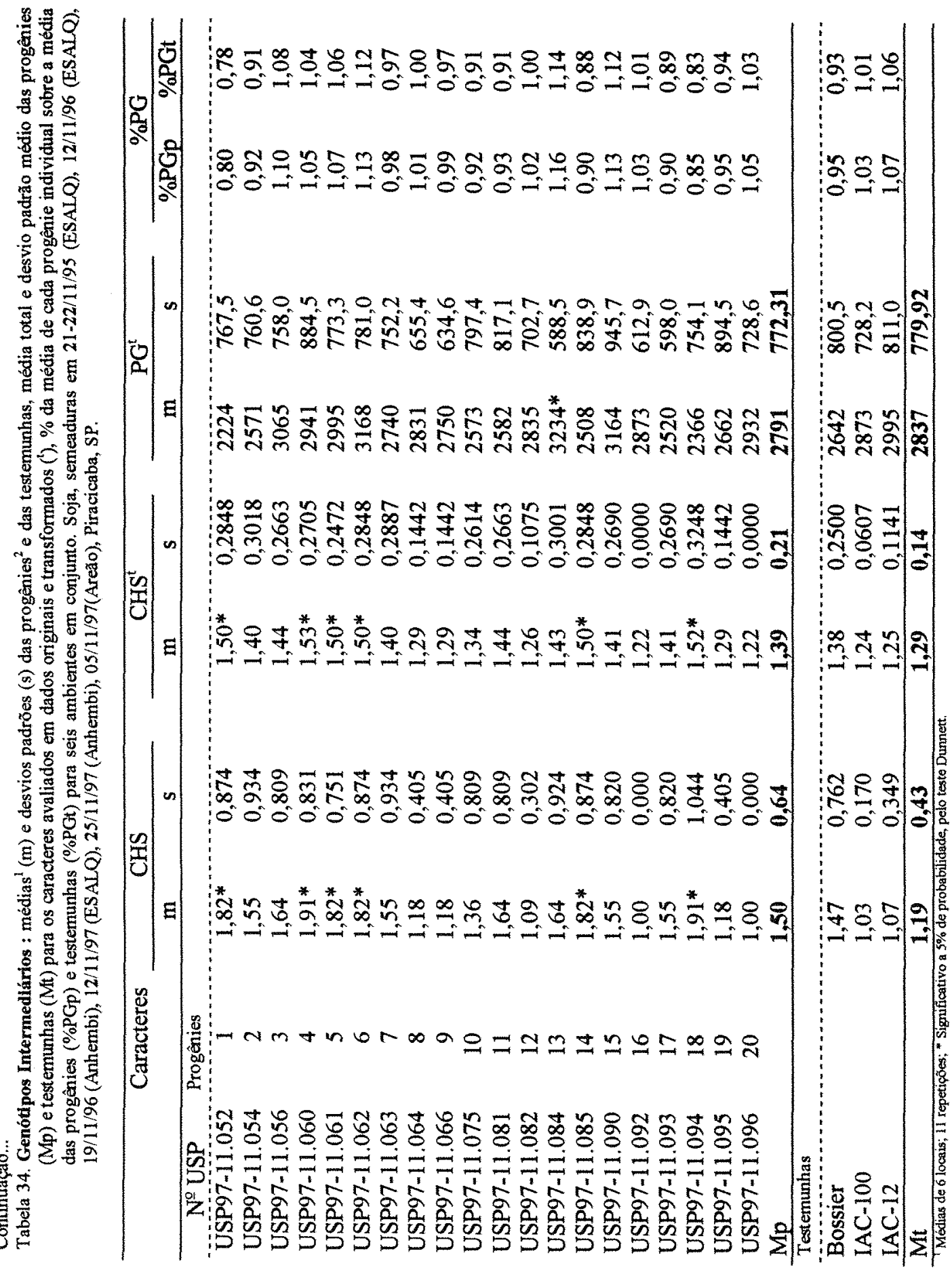




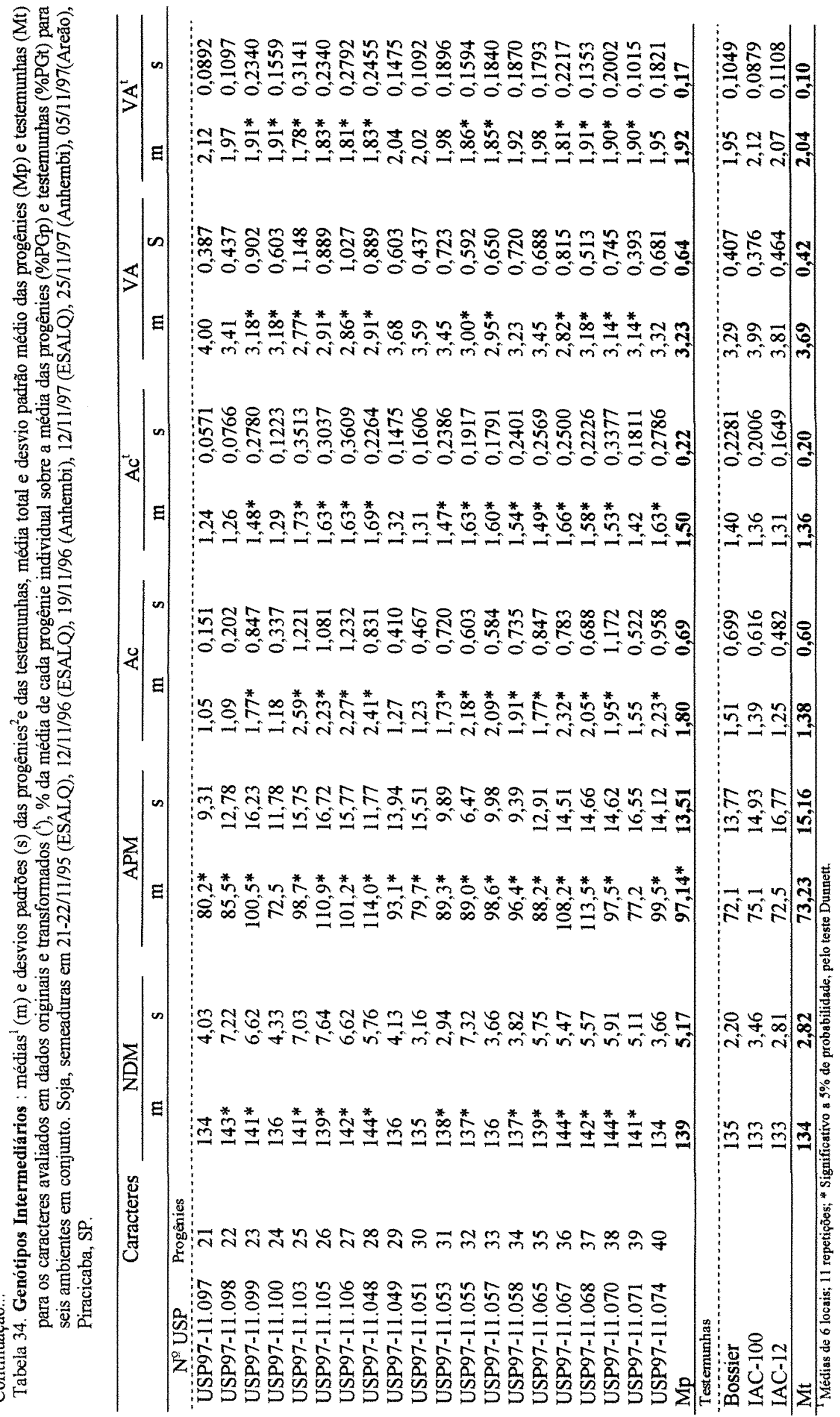









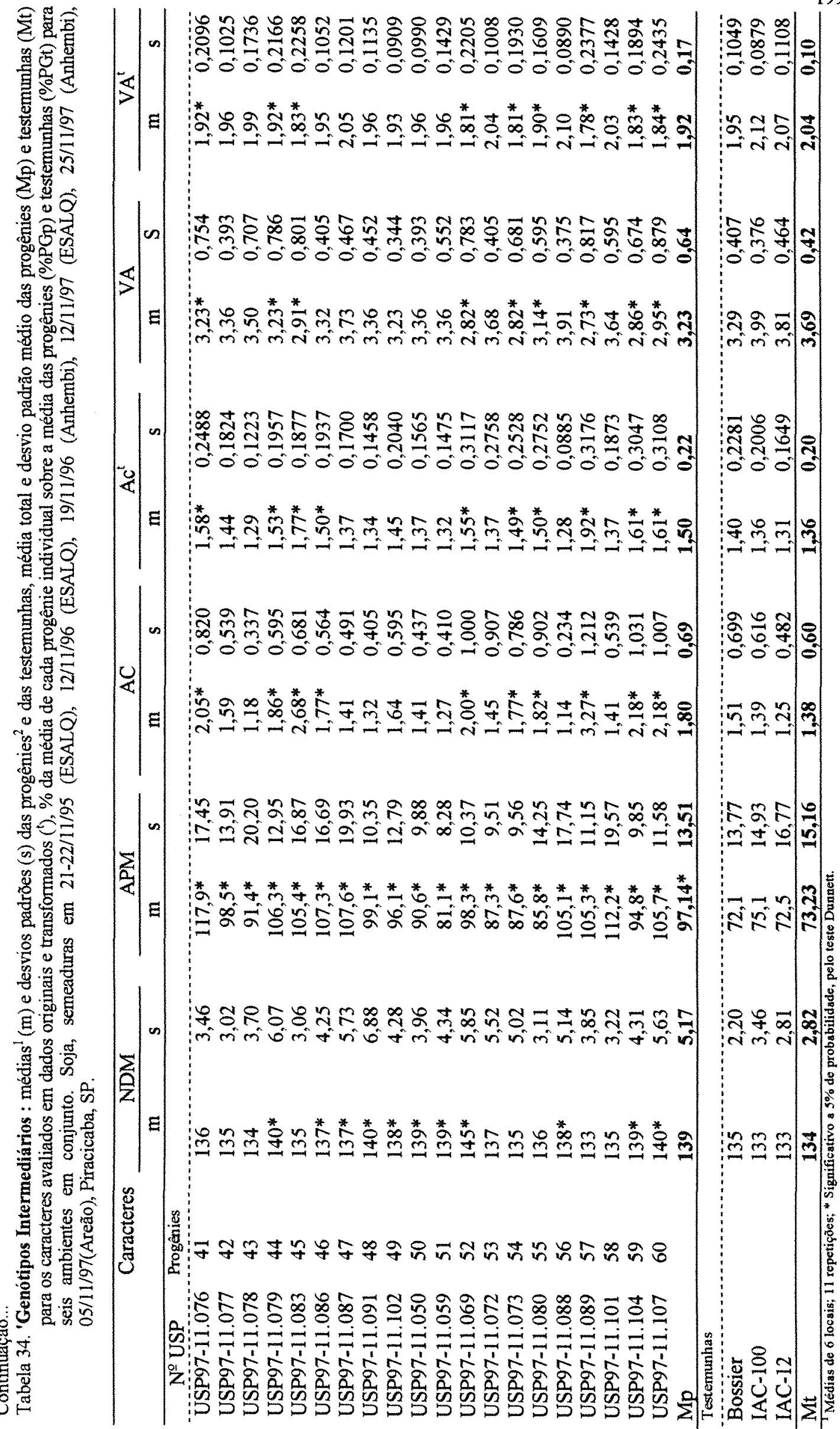




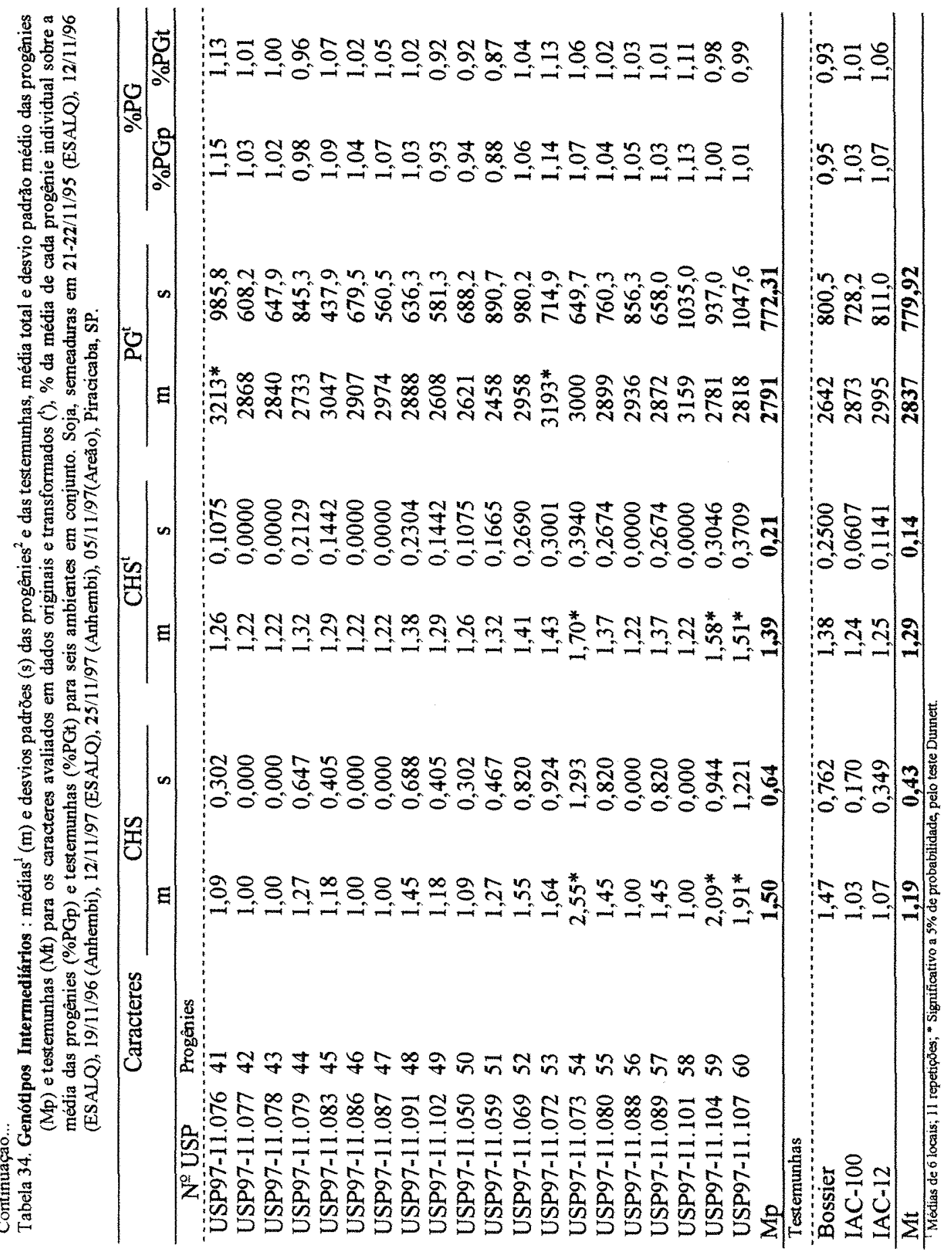




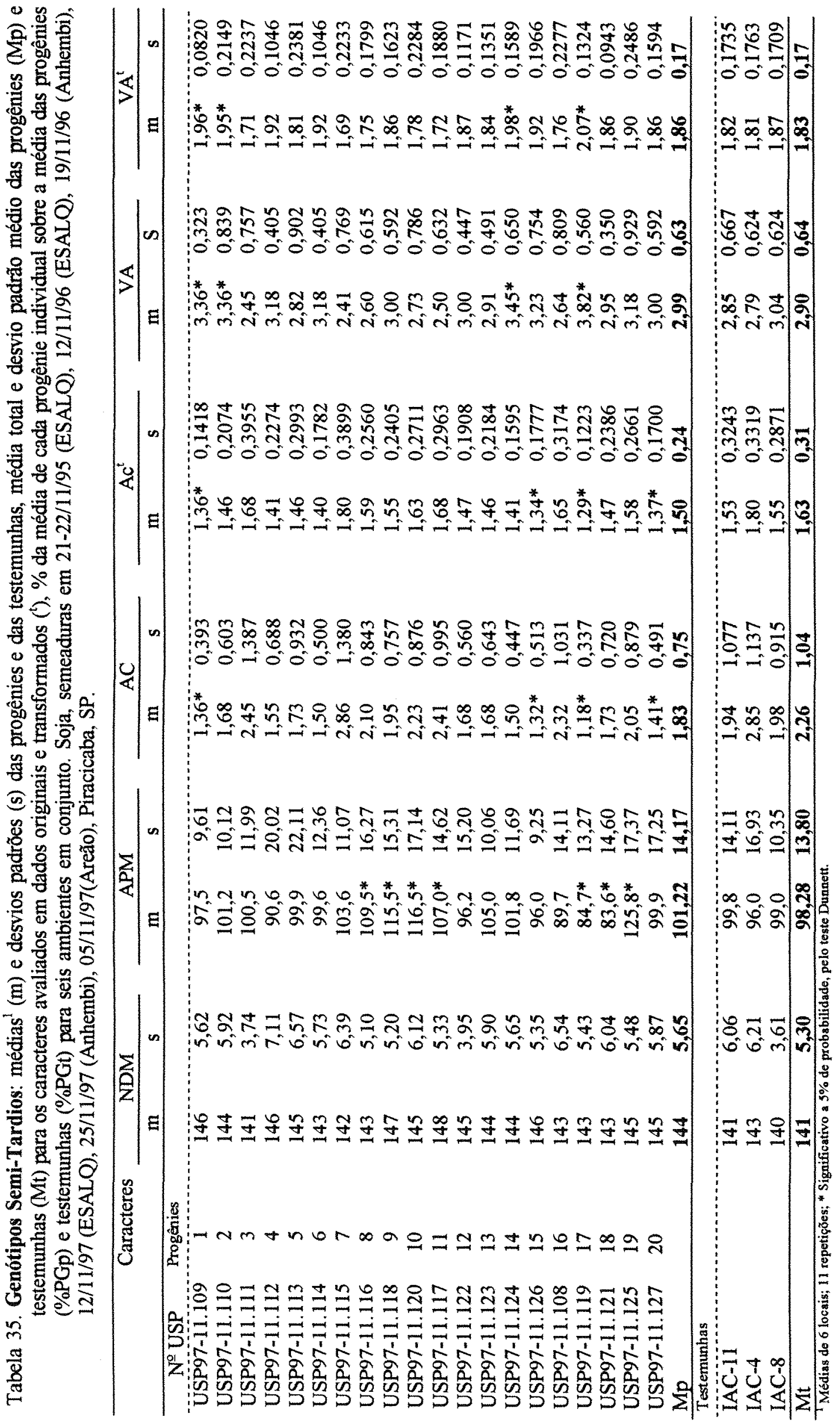




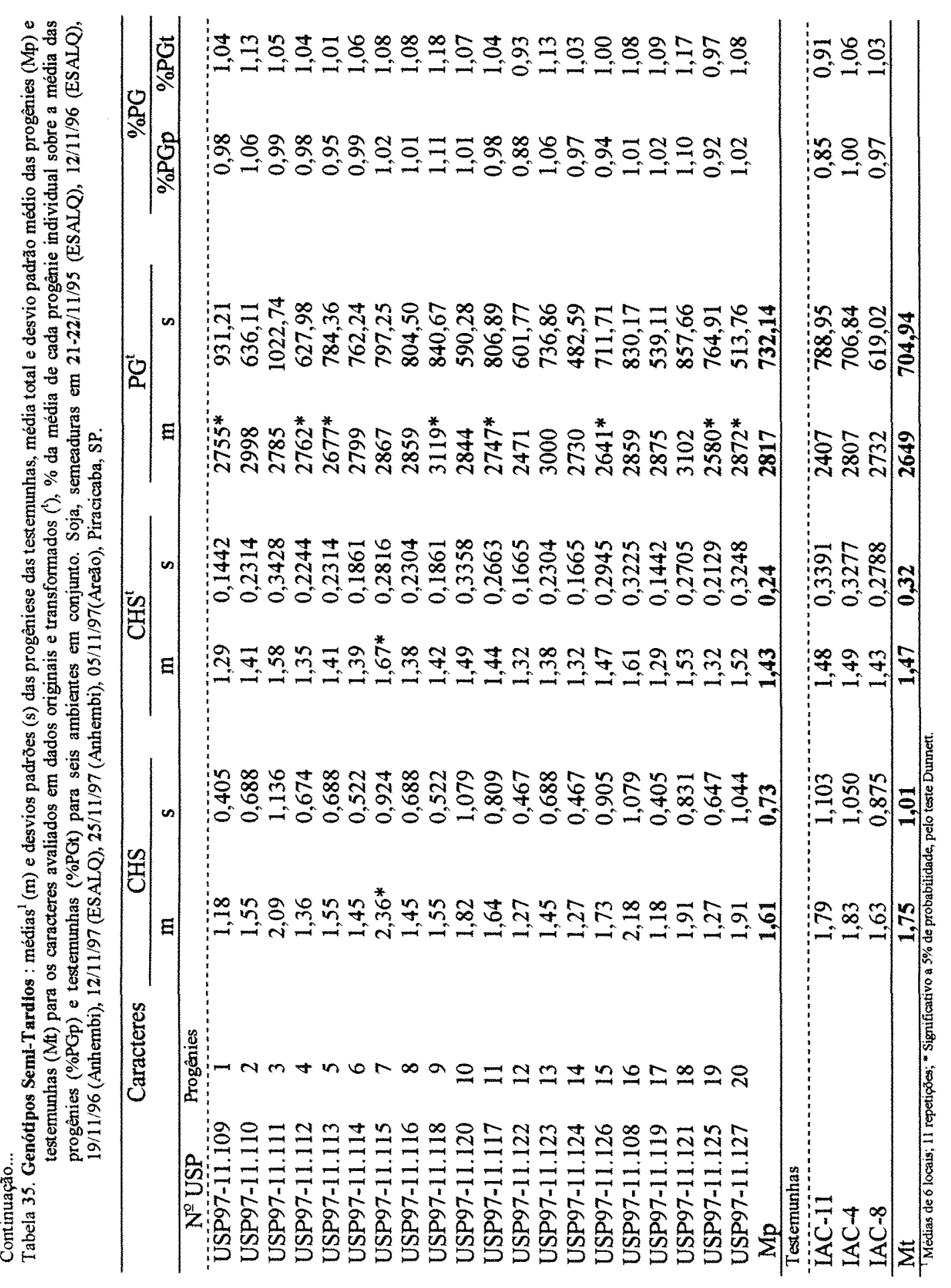


Tabela 36. Genótipos Precoces: correlações fenotipicas (\%) entre os caracteres número de dias para a maturidade (NDM), altura da planta na maturidade (APM), acamamento (Ac), valor agronômico (VA), reação ao cancro-da-haste da soja (CHS) e produtividade de grãos (PG) ao nível de parcelas experimentais, dentro do grupo das progênies e testemunhas para seis ambientes em conjunto. Soja, semeaduras em 21-22/11/95 (ESALQ), 12/11/96 (ESALQ), 19/11/96 (Anhembi), 12/11/97 (ESALQ), 25/11/97 (Anhembi), 05/11/97(Areão), Piracicaba, SP.

\begin{tabular}{|c|c|c|c|c|c|}
\hline Caracteres & APM & $\mathrm{Ac}^{\mathrm{a}}$ & $\mathrm{VA}^{\mathrm{a}}$ & $\mathrm{CHS}^{\mathrm{a}}$ & PG \\
\hline $\begin{array}{l}\text { NDM (progênies) } \\
\text { (testemunhas) }\end{array}$ & $\begin{array}{r}6,00 \mathrm{~ns} \\
-49,46^{* *}\end{array}$ & $\begin{array}{l}-22,14^{* *} \\
-29,24 \mathrm{~ns}\end{array}$ & $\begin{array}{r}-3,55 \mathrm{~ns} \\
-19,09 \mathrm{~ns}\end{array}$ & $\begin{array}{r}-2,69 \mathrm{~ns} \\
-15,54 \mathrm{~ns}\end{array}$ & $\begin{array}{l}-39,42^{* *} \\
-43,26^{* *}\end{array}$ \\
\hline $\begin{array}{l}\text { APM (progênies) } \\
\text { (testemunhas) }\end{array}$ & & $\begin{array}{l}68,33^{* *} \\
33,94 *\end{array}$ & $\begin{array}{r}-14,47^{*} \\
30,64^{*}\end{array}$ & $\begin{array}{l}15,03^{*} \\
4,44 \mathrm{~ns}\end{array}$ & $\begin{array}{l}30,42^{* *} \\
52,26^{* *}\end{array}$ \\
\hline $\begin{array}{ll}\mathrm{Ac}^{\mathrm{a}} \quad \text { (progênies) } \\
\text { (testemunhas) }\end{array}$ & & & $\begin{array}{r}-35,74^{* *} \\
1,79 \mathrm{~ns}\end{array}$ & $\begin{array}{l}18,84^{* *} \\
14,27 \mathrm{~ns}\end{array}$ & $\begin{array}{l}23,65^{* *} \\
56,89^{* *}\end{array}$ \\
\hline $\begin{array}{l}\mathrm{VA}^{\mathrm{a}} \quad \text { (progênies) } \\
\text { (testemunhas) }\end{array}$ & & & & $\begin{array}{r}-28,98 * * \\
-4,03 \mathrm{~ns}\end{array}$ & $\begin{array}{l}30,46^{* *} \\
33,68^{*}\end{array}$ \\
\hline $\begin{array}{l}\text { CHS }^{\text {a }} \text { (progênies) } \\
\text { (testemunhas) }\end{array}$ & & & & & $\begin{array}{l}-3,04 \mathrm{~ns} \\
-3,16 \mathrm{~ns}\end{array}$ \\
\hline
\end{tabular}

*, ** : significativo ao nivel de $5 \%$ e $1 \%$ de probabilidade, respectivamente, pelo teste $\mathrm{F}$;

ns : não-significativo pelo teste $\mathrm{F}$.

${ }^{a}$ : análise realizada com dados transformados para $\sqrt{x+0,5}$, com $x=1$ a 5 (Ac e VA) e $x=1$ a 4 (CHS).

Tabela 37. Genótipos Semi-Precoces : correlações fenotípicas (\%) entre os caracteres número de dias para a maturidade (NDM), altura da planta na maturidade (APM), acamamento (Ac), valor agronômico (VA), reação ao cancro-da-haste da soja (CHS) e produtividade de grãos (PG) ao nível de parcelas experimentais, dentro do grupo das progênies e testemunhas para seis ambientes em conjunto. Soja, semeaduras em 21-22/11/95 (ESALQ), 12/1 1/96 (ESALQ), 19/1 1/96 (Anhembi), 12/1 1/97 (ESALQ), 25/11/97 (Anhembi), 05/11/97(Areão), Piracicaba, SP.

\begin{tabular}{|c|c|c|c|c|c|}
\hline Caracteres & APM & $A c^{a}$ & $\mathrm{VA}^{\mathrm{a}}$ & $\mathrm{CHS}^{\mathrm{a}}$ & $\mathrm{PG}$ \\
\hline $\begin{array}{l}\text { NDM (progênies) } \\
\text { (testemunhas) }\end{array}$ & $\begin{array}{l}14,89^{* *} \\
48,98^{* *}\end{array}$ & $\begin{array}{l}-6,58 \mathrm{~ns} \\
22,95^{*}\end{array}$ & $\begin{array}{l}-30,55^{* *} \\
-27,73^{* *}\end{array}$ & $\begin{array}{l}9,67 \mathrm{~ns} \\
2,98 \mathrm{~ns}\end{array}$ & $\begin{array}{r}-25,32 * * \\
0,26 \mathrm{~ns}\end{array}$ \\
\hline $\begin{array}{l}\text { APM (progênies) } \\
\text { (testemunhas) }\end{array}$ & & $\begin{array}{l}34,98^{* *} \\
49,67^{* *}\end{array}$ & $\begin{array}{l}-10,61^{*} \\
-13,16 \mathrm{~ns}\end{array}$ & $\begin{array}{r}19,25^{* *} \\
-16,12 \mathrm{~ns}\end{array}$ & $\begin{array}{l}28,35^{* *} \\
48,51^{* *}\end{array}$ \\
\hline $\begin{array}{ll}\mathrm{Ac}^{\mathrm{a}} & \text { (progênies) } \\
& \text { (testemunhas) }\end{array}$ & & & $\begin{array}{l}-54,36 * * \\
-62,79 * *\end{array}$ & $\begin{array}{l}36,86^{* *} \\
-9,62 \mathrm{~ns}\end{array}$ & $\begin{array}{l}10,52^{*} \\
41,31 * *\end{array}$ \\
\hline $\begin{array}{ll}\mathrm{VA}^{\mathrm{a}} & \text { (progênies) } \\
\text { (testemunhas) }\end{array}$ & & & & $\begin{array}{l}-53,15^{* *} \\
-15,02 \mathrm{~ns}\end{array}$ & $\begin{array}{l}29,02 * * \\
-3,33 \mathrm{~ns}\end{array}$ \\
\hline $\begin{array}{l}\mathrm{CHS}^{\mathrm{a}} \text { (progênies) } \\
\text { (testemunhas) }\end{array}$ & & & & & $\begin{array}{l}-13,72^{*} \\
-22,34^{*}\end{array}$ \\
\hline
\end{tabular}

*,**: significativo ao nível de $5 \%$ e $1 \%$ de probabilidade, respectivamente, pelo teste $\mathrm{F}$;

ns : não-significativo pelo teste $\mathrm{F}$.

a : análise realizada com dados transformados para $\sqrt{x+0,5}, \operatorname{com} x=1$ a 5 (Ac e VA) e $x=1$ a 4 (CHS). 
Tabela 38. Genótipos Intermediários : correlaçðes fenotípicas (\%) entre os caracteres número de dias para a maturidade (NDM), altura da planta na maturidade (APM), acamamento (Ac), valor agronômico (VA), reação ao cancro-da-haste da soja (CHS) e produtividade de grãos (PG) ao nível de parcelas experimentais, dentro do grupo das progênies e testemunhas para seis ambientes em conjunto. Soja, semeaduras em 21-22/11/95 (ESALQ), 12/1 1/96 (ESALQ), 19/11/96 (Anhembi), 12/11/97 (ESALQ), 25/11/97 (Anhembi), 05/11/97(Areão), Piracicaba, SP.

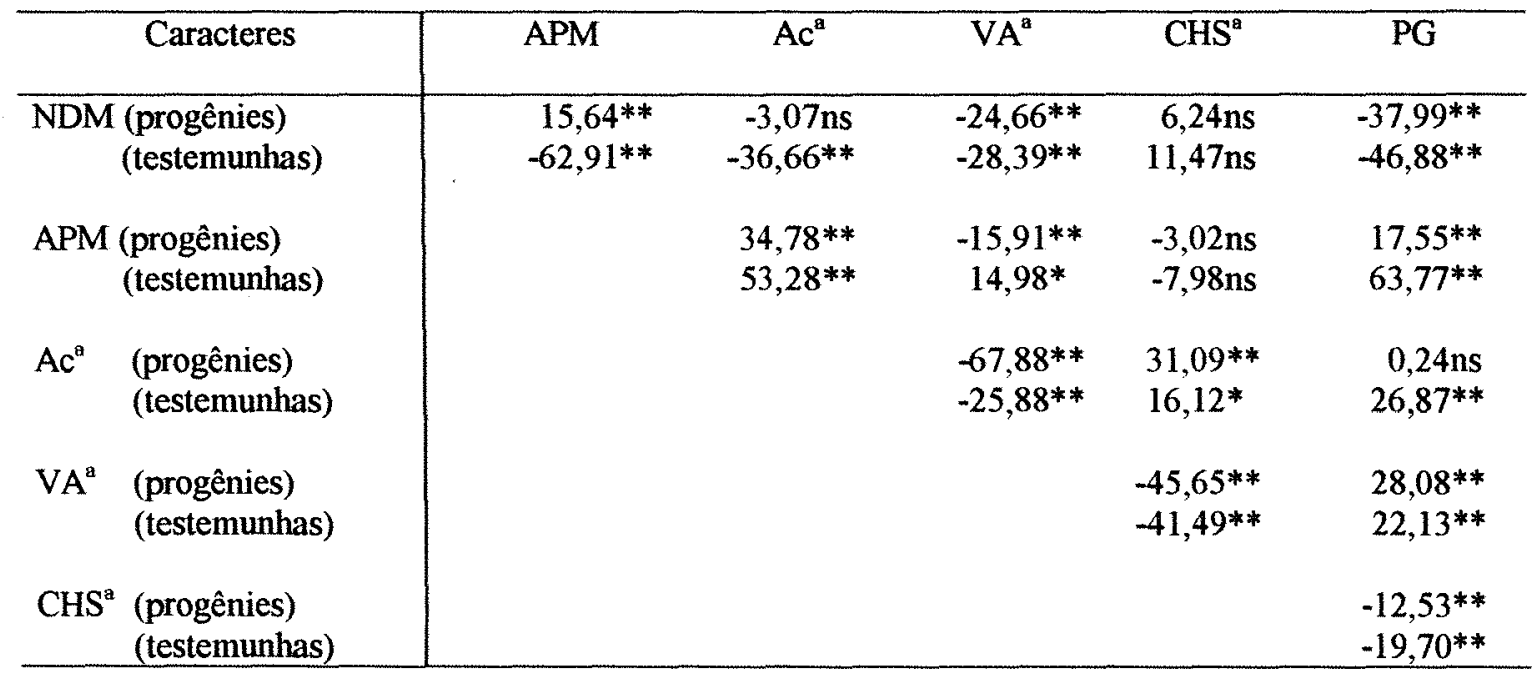

*,**: significativo ao nível de $5 \%$ e $1 \%$ de probabilidade, respectivamente, pelo teste $\mathrm{F}$;

ns : não-significativo pelo teste $F$.

a : análise realizada com dados transformados para $\sqrt{x+0,5}, \operatorname{com} x=1$ a 5 (Ac e VA) e $x=1$ a 4 (CHS).

Tabela 39. Genótipos Semi-Tardios: correlações fenotípicas (\%) entre os caracteres número de dias para a maturidade (NDM), altura da planta na maturidade (APM), acamamento (Ac), valor agronômico (VA), reação ao cancro-da-haste da soja (CHS) e produtividade de grãos (PG) ao nível de parcelas experimentais, dentro do grupo das progênies e testemunhas para seis ambientes em conjunto. Soja, semeaduras em 21-22/11/95 (ESALQ), 12/11/96 (ESALQ), 19/11/96 (Anhembi), 12/11/97 (ESALQ), 25/11/97 (Anhembi), 05/11/97(Areão), Piracicaba, SP.

\begin{tabular}{c|ccccc}
\hline Caracteres & $\mathrm{APM}$ & $\mathrm{Ac}^{\mathrm{a}}$ & $\mathrm{VA}^{\mathrm{a}}$ & $\mathrm{CHS}$ & $\mathrm{PG}$ \\
\hline NDM (progênies) & $21,45^{* *}$ & $-0,31 \mathrm{~ns}$ & $-15,08^{*}$ & $-8,47 \mathrm{~ns}$ & $-10,19 \mathrm{~ns}$ \\
(testemunhas) & $5,00 \mathrm{~ns}$ & $-23,10^{*}$ & $-11,80 \mathrm{~ns}$ & $-22,50^{*}$ & $-11,57 \mathrm{~ns}$ \\
& & & & & \\
$\mathrm{APM}$ (progênies) & & $36,84^{* *}$ & $-8,69 \mathrm{~ns}$ & $7,48 \mathrm{~ns}$ & $14,97^{*}$ \\
(testemunhas) & & $26,56^{*}$ & $5,58 \mathrm{~ns}$ & $26,20^{*}$ & $25,82^{*}$ \\
$\mathrm{Ac} \quad$ (progênies) & & & $-71,02^{* *}$ & $48,88^{* *}$ & $-17,06^{*}$ \\
(testemunhas) & & & $-50,91^{* *}$ & $43,70^{* *}$ & $3,29 \mathrm{~ns}$ \\
$\mathrm{VA} \quad$ (progênies) & & & & $-51,08^{* *}$ & $32,51^{* *}$ \\
(testemunhas) & & & & $-20,22 \mathrm{~ns}$ & $38,37^{* *}$ \\
$\mathrm{CHS}^{\mathrm{a}}$ (progênies) & & & & & $-13,86^{*}$ \\
(testemunhas) & & & & & $0,38 \mathrm{~ns}$ \\
\hline
\end{tabular}

${ }^{*},{ }^{* *}$ : significativo ao nível de $5 \%$ e $1 \%$ de probabilidade, respectivamente, pelo teste $\mathrm{F}$; ns : não-significativo pelo teste $\mathrm{F}$.

${ }^{a}$ : análise realizada com dados transformados para $\sqrt{x+0,5}$, com $x=1$ a 5 (Ac e VA) e $x=1$ a 4 (CHS). 
Tabela 40. Correlações genéticas (\%) entre os caracteres número de dias para a maturidade (NDM), altura da planta na maturidade (APM), acamamento (Ac), valor agronômico (VA), reação ao cancroda-haste da soja (CHS) e produtividade de grãos (PG) avaliados nas progênies ao nível de parcelas experimentais, para cada grupo de maturação, em análise de seis ambientes em conjunto. Soja, semeaduras em 21-22/11/95 (ESALQ), 12/11/96 (ESALQ), 19/11/96 (Anhembi), 12/11/97 (ESALQ), 25/11/97 (Anhembi), 05/1 1/97(Areão), Piracicaba, SP.

\begin{tabular}{|c|c|c|c|c|c|c|}
\hline Caracteres & $\begin{array}{c}\text { Ciclos } \\
\text { maturação }\end{array}$ & $\overline{\mathrm{APM}}$ & $\overline{A c^{2}}$ & $\overline{V^{2}}$ & $\mathrm{CHS}^{\mathrm{a}}$ & PG \\
\hline \multirow[t]{4}{*}{ NDM } & Precoce & 59,91 & 20,75 & 15,35 & 37,52 & 21,39 \\
\hline & Semi-Precoce & 39,57 & 0,99 & $-50,07$ & 55,23 & 0,85 \\
\hline & Intermediário & 33,29 & 22,33 & $-47,11$ & 42,18 & $-61,30$ \\
\hline & Semi-Tardio & 38,83 & $-3,95$ & 22,22 & $-42,93$ & $-99,52$ \\
\hline \multirow[t]{4}{*}{ APM } & Precoce & & 82,46 & $-2,17$ & $-34,86$ & $-18,50$ \\
\hline & Semi-Precoce & & 44,67 & 12,14 & $-1,94$ & $<(-100)$ \\
\hline & Intermediário & & 61,12 & $-44,34$ & $-23,53$ & 0,90 \\
\hline & Semi-Tardio & & $-43,62$ & $<(-100)$ & $-7,34$ & $-35,94$ \\
\hline \multirow[t]{4}{*}{$\mathrm{Ac}^{\mathrm{a}}$} & Precoce & & & $-31,89$ & $-19,29$ & $-17,98$ \\
\hline & Semi-Precoce & & & $-53,52$ & 42,53 & $<(-100)$ \\
\hline & Intermediário & & & $-84,63$ & 25,93 & $-14,19$ \\
\hline & Semi-Tardio & & & $-86,63$ & 66,59 & $<(-100)$ \\
\hline \multirow[t]{4}{*}{$\mathrm{VA}^{\mathrm{s}}$} & Precoce & & & & $-32,96$ & 57,32 \\
\hline & Semi-Precoce & & & & $<(-100)$ & 81,97 \\
\hline & Intermediário & & & & $-60,71$ & 47,34 \\
\hline & Semi-Tardio & & & & $-86,22$ & $<(-100)$ \\
\hline \multirow[t]{4}{*}{$\mathrm{CHS}^{\mathrm{a}}$} & Precoce & & & & & $-59,80$ \\
\hline & Semi-Precoce & & & & & 64,03 \\
\hline & Intermediário & & & & & $-21,44$ \\
\hline & Semi-Tardio & & & & & $<(100)$ \\
\hline
\end{tabular}

a : análise realizada com dados transformados para $\sqrt{x+0,5}, \operatorname{com} x=1$ a 5 (Ac e VA) e $x=1$ a 4 (CHS). 
Tabela 41. Relação entre o maior e menor quadrados médios residuais das análises de variância individuais referentes aos caracteres número de dias para maturidade (NDM), altura da planta na maturidade (APM), acamamento (Ac), valor agronômico (VA), reação ao cancro-da-haste da soja (CHS) e produtividade de grãos (PG), Soja, semeaduras em 21-22/11/95 (ESALQ), 12/11/96 (ESALQ), 19/11/96 (Anhembi), 12/11/97 (ESALQ), 25/11/97 (Anhembi), 05/11/97 (Areão), Piracicaba, SP.

\begin{tabular}{|c|c|c|c|c|c|c|c|c|}
\hline $\begin{array}{l}\text { CICLO DE } \\
\text { MATURACÃO }\end{array}$ & GL & NDM & $\mathbf{A P M}$ & Ac & VA & CHS & GL & PG \\
\hline \multicolumn{9}{|l|}{ GRUPO PRECOCE } \\
\hline QMRes/ESALQ95 & 26 & 8,23 & 170,56 & 0,0373 & 0,0125 & 0,0043 & 25 & 265056 \\
\hline QMRes/ESALQ96 & 16 & & & & & 0,0122 & 16 & 967 \\
\hline QMRes/ANHEMBI96 & 16 & & & & & 0,0260 & 16 & 950 \\
\hline Relação QMRes (Ano 96) & & & & 1,46 & 1,15 & 2,13 & & 1,37 \\
\hline QMRes/ANHEMBI97 & 16 & 2,05 & 77,68 & 0,0092 & 0,0056 & 0,0058 & 16 & 207993 \\
\hline QMRes/ESALQ97 & 16 & & 101,56 & & & 0,0299 & 16 & 227428 \\
\hline QMRes/AREÃO97 & 16 & 6,22 & 72,87 & 0,0159 & 0,0144 & 0,0048 & 16 & 125333 \\
\hline Relacão QMRes (Ano & & $\mathbf{3 , 0 3}$ & 1,39 & 5,70 & 3,89 & 6,23 & & 1,81 \\
\hline Relação QMRes Total & & 4,01 & 2,34 & 6,16 & 3,89 & 6,95 & & 2,11 \\
\hline \multicolumn{9}{|l|}{ GRUPO SEMI-PRECOCE } \\
\hline QMRes/ESALQ96 & 58 & 3,12 & 63 & 0,0177 & 0,0113 & 0,0141 & 58 & 423 \\
\hline QMRes/ANHEMBI96 & 58 & & & & & 0,0 & 58 & 182303 \\
\hline Relação QMRes (Ano & & 1,1 & 1,30 & 1,00 & 1,26 & 2,29 & & 1,12 \\
\hline /ANHEMBI97 & 29 & & & & & & 29 & 34 \\
\hline SALQ97 & 29 & 6 , & 14 & & & 48 & 29 & 222439 \\
\hline QMRes/AREÃO97 & 29 & 5,78 & 89,25 & 0,0152 & 0,0103 & 0,0204 & 29 & 253046 \\
\hline Relação QMRes (Ano & & 1,70 & 2,08 & 3,65 & 1,82 & 3,67 & & 1,67 \\
\hline Relação QMRes Total & & 2,33 & 2,31 & 5 & 2,08 & 5,30 & & 1,6 \\
\hline \multicolumn{9}{|l|}{ GRUPO INTERMEDIÁRI } \\
\hline QMRes/ESALQ95 & 39 & & & & & & 38 & 3. \\
\hline ESALQ96 & 178 & 5 , & 133,11 & 0,034 & & 01 & 178 & 25 \\
\hline QMRes/ANHEMBI96 & 178 & 6,69 & 89,68 & 0,0367 & 0,0101 & 0,0857 & 176 & 33096 \\
\hline Relação QMRes (An & & 1,12 & 1,48 & 1,08 & 1,07 & 1,71 & & 1,2 \\
\hline QMRes/ANHEMBI97 & 59 & 2,98 & 117,26 & 0,0105 & 0,0075 & 0,0195 & 59 & 226133 \\
\hline SALQ97 & 59 & 4,2 & 109,03 & 0,0357 & 0,0196 & 0,0377 & 58 & 27899 \\
\hline QMRes/AREÃO97 & 59 & 10,44 & 92,68 & 0,0222 & 0,0141 & 0,036 & 59 & 186942 \\
\hline MRes (Ano & & $\mathbf{3 , 5 0}$ & 1,27 & 3,40 & 2,61 & 1,93 & & 1,4 \\
\hline Relação QMRes Total & & 456 & 07 & 470 & 2,61 & 4,39 & & 1,8 \\
\hline \multicolumn{9}{|l|}{ GRUPO SEMI-TARDIO } \\
\hline QMRes/ESALQ95 & 15 & & & & & & 15 & \\
\hline QMMRes/ESALQ96 & 51 & 3,59 & 170,53 & 0,0335 & 0,0112 & 0,0256 & 51 & 40624 \\
\hline QMRes/ANHEMBIS & 51 & 5,74 & 148,76 & 0,039 & 0,0133 & 0,0682 & 50 & 27305 \\
\hline Relação QMRes (Ano 96 & & 1,88 & 1,15 & 1,16 & 1,19 & 2,66 & & 1,4 \\
\hline NHEMBI97 & 19 & & & & & & 19 & 14 \\
\hline QMRes/ESALQ97 & 19 & 0,84 & 85,73 & 0,0264 & 0,0217 & 0,0644 & 19 & 51781 \\
\hline QMRes/AREÃO97 & 19 & 2,54 & 97,69 & 0,0671 & 0,026 & 0,0475 & 19 & 62491 \\
\hline Relação QMRes (Ano 97) & & 3,35 & 1,81 & 5,16 & 1,47 & 3,72 & & 3,8 \\
\hline Relação QMRes Total & & 6,83 & 1,99 & 6,29 & 2,32 & 6,96 & & 3,8 \\
\hline
\end{tabular}




\section{FIGURAS}




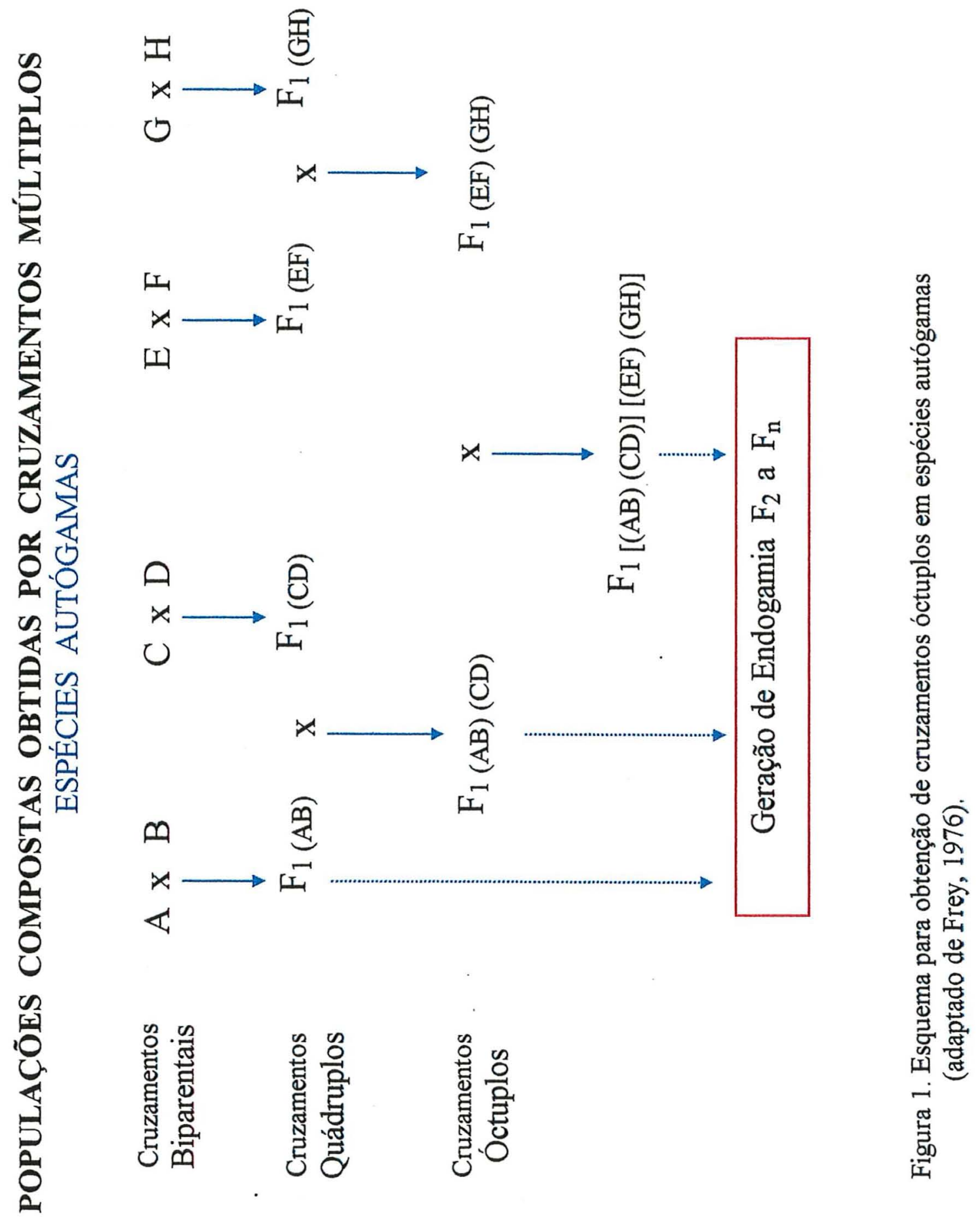




\section{Resíduo \\ padronizado}

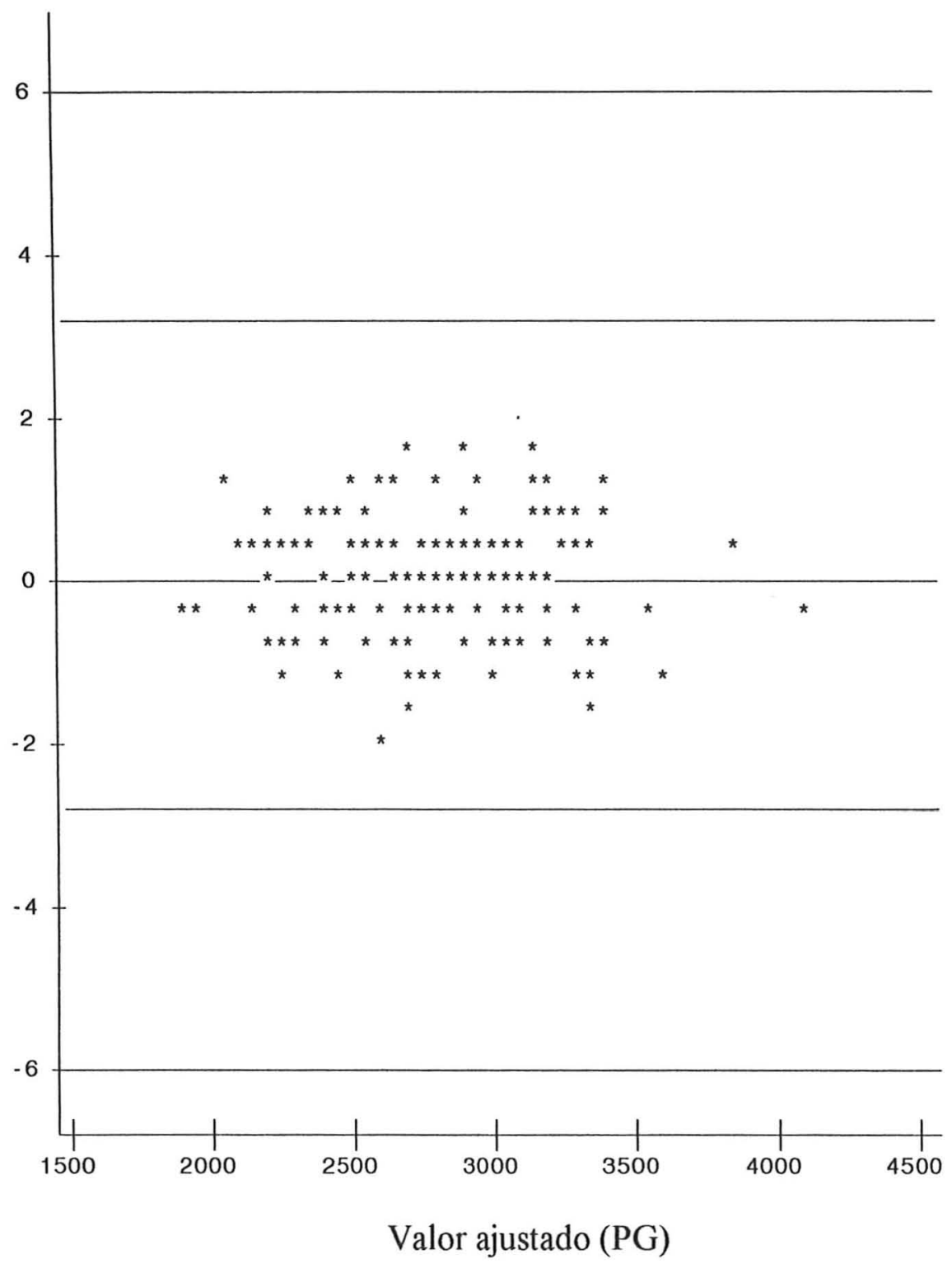

OBS.: 38 observações sobrepostas

Figura 2. Representação gráfica dos resíduos padronizados e valores ajustados para o caráter produtividade de grãos (PG), experimento intermediário, local Anhembi, ano 1997/98. Soja, Piracicaba, SP (semeadura em 25/11/97). 

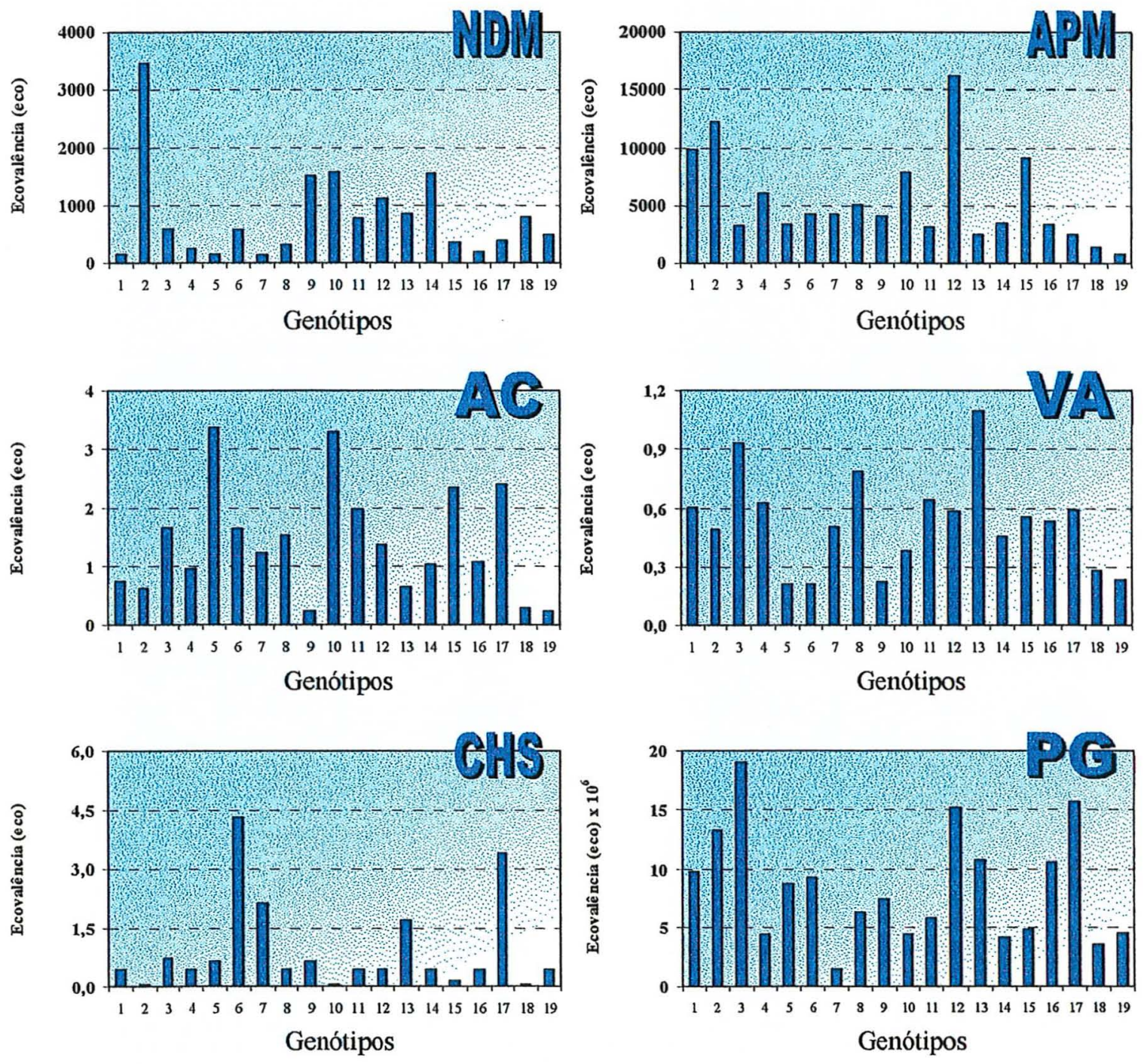

Figura 3 - Genótipos Precoces: estimativa da interação G x E através da ecovalência (eco) estimada pelo Teste de Wricke para as médias dos genótipos na análise conjunta de seis ambientes, referentes aos caracteres NDM (número de dias para a maturidade), APM (altura da planta na maturidade), Ac (acamamento), VA (valor agronômico), CHS (reação ao cancro-da-haste da soja) e PG (produtividade de grãos). Soja, semeaduras em 1995 (ESALQ), 1996 (ESALQ e Anhembi) e 1997 (ESALQ, Anhembi e Areão). Piracicaba, SP. 

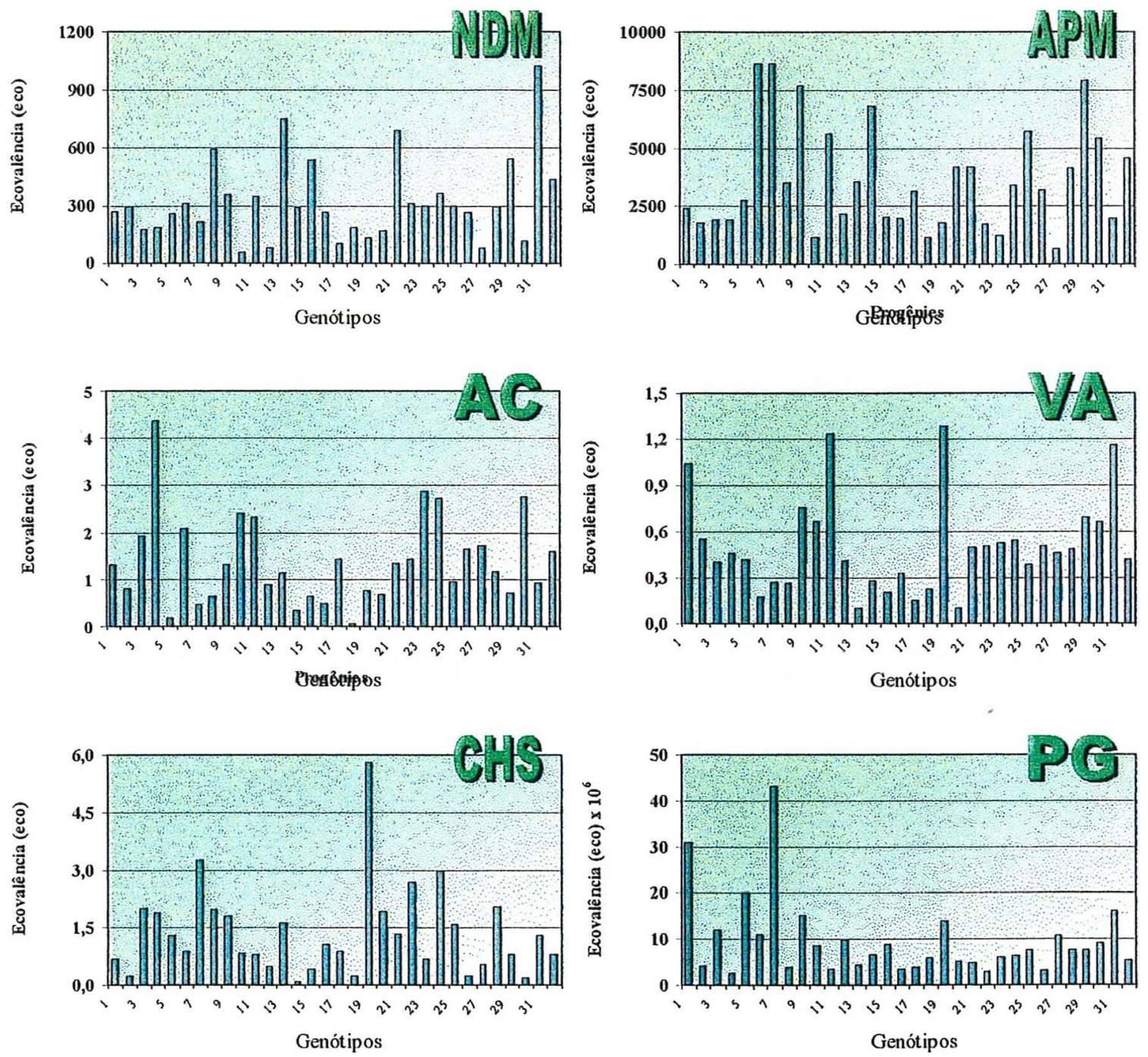

Figura 4 - Genótipos Semi-Precoces: estimativa da interação $G \times$ E através da ecovalência (eco) estimada pelo Teste de Wricke para as médias dos genótipos na análise conjunta de seis ambientes, referentes aos caracteres NDM (número de dias para a maturidade), APM (altura da planta na maturidade), Ac (acamamento), VA (valor agronômico), CHS (reação ao cancro-da-haste da soja) e PG (produtividade de grãos). Soja, semeaduras em 1995 (ESALQ), 1996 (ESALQ e Anhembi) e 1997 (ESALQ, Anhembi e Areão). Piracicaba, SP. 

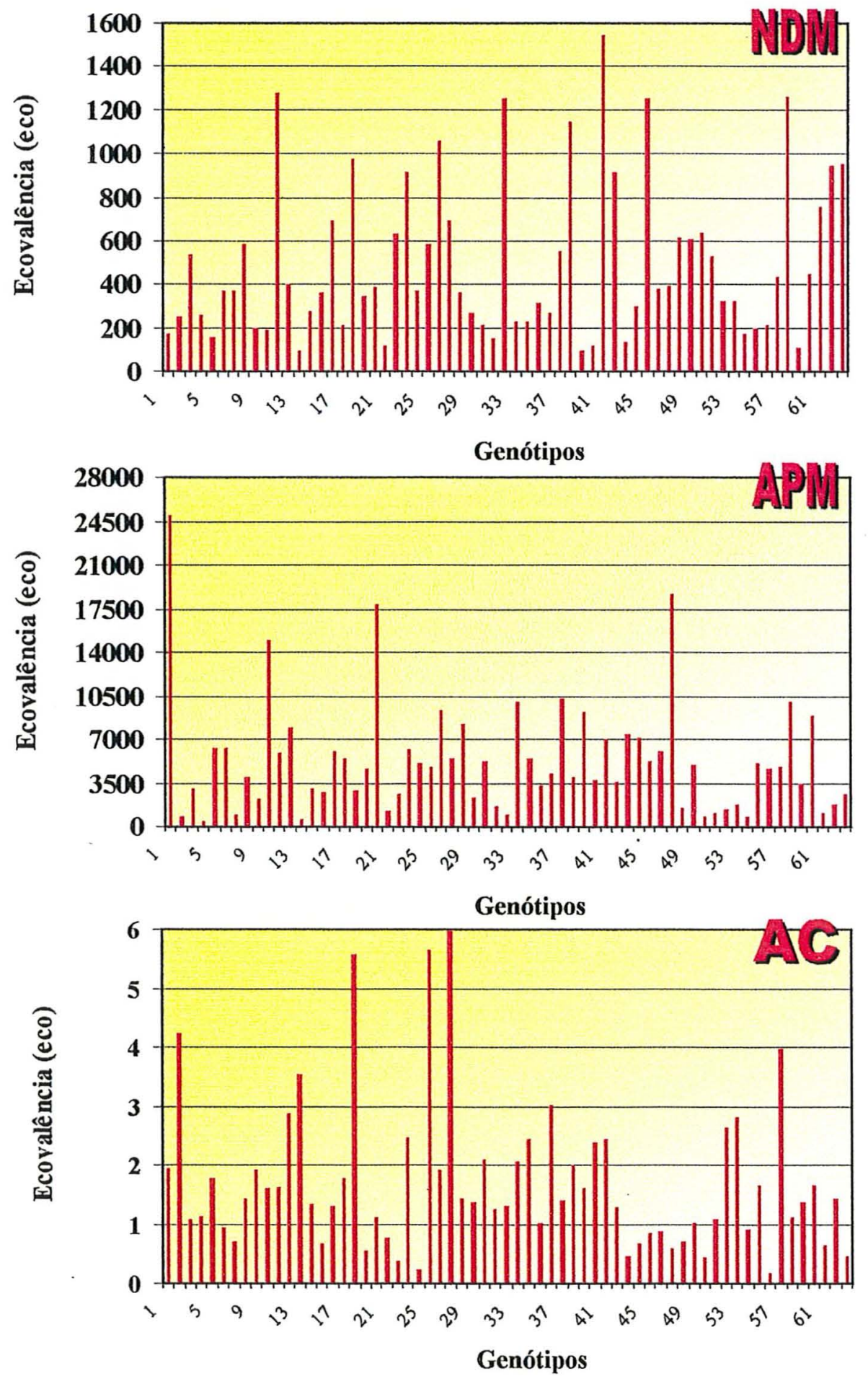

Figura 5 - Genótipos Intermediários: estimativa da interação $\mathrm{G} \times \mathrm{E}$ através da ecovalência (eco) estimada pelo Teste de Wricke para as médias dos genótipos na análise conjunta de seis ambientes, referentes aos caracteres NDM (número de dias para a maturidade), APM (altura da planta na maturidade) e Ac (acamamento). Soja, semeaduras em 1995 (ESALQ), 1996 (ESALQ e Anhembi) e 1997 (ESALQ, Anhembi e Areão). Piracicaba, SP. 

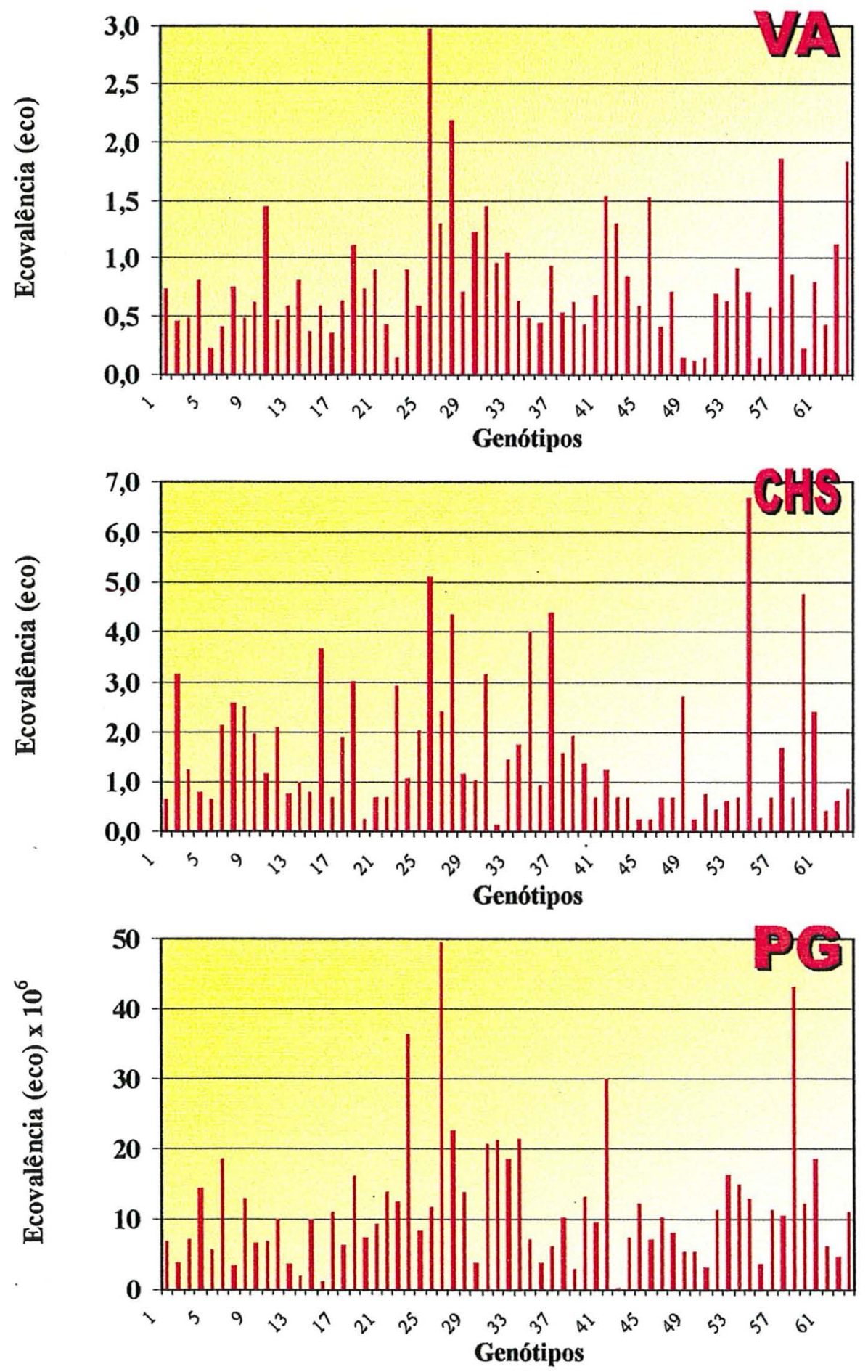

Figura 6 - Genótipos Intermediários: estimativa da interação $\mathrm{G} \times \mathrm{E}$ através da ecovalência (eco) estimada pelo Teste de Wricke para as médias dos genótipos na análise conjunta de seis ambientes, referentes aos caracteres VA (valor agronômico), CHS (reação ao cancro-da-haste da soja) e PG (produtividade de grãos). Soja, semeaduras em 1995 (ESALQ), 1996 (ESALQ e Anhembi) e 1997 (ESALQ, Anhembi e Areão). Piracicaba, SP. 

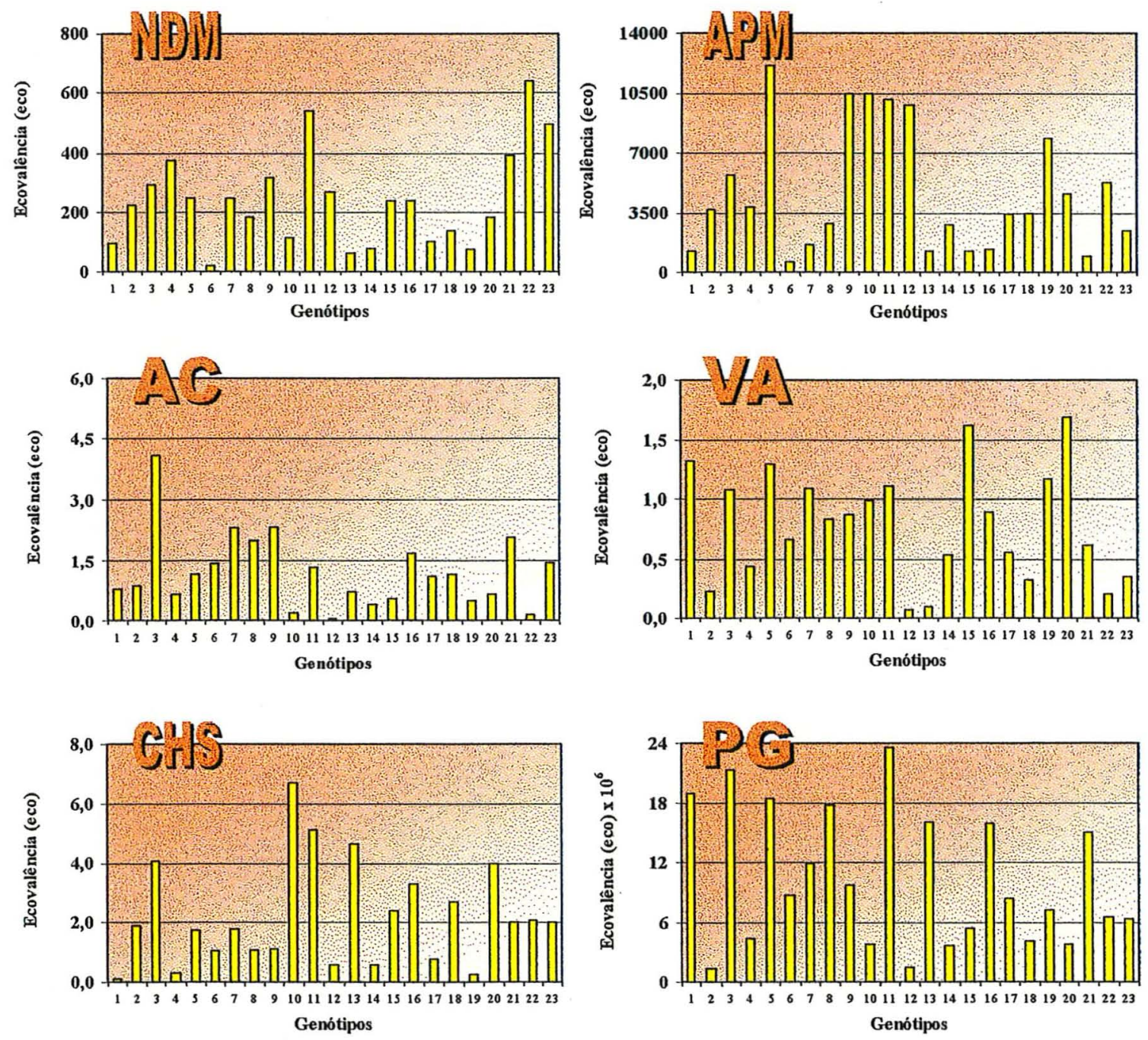

Figura 7 - Genótipos Semi-Tardios: estimativa da interação $G \times$ E através da ecovalência (eco) estimada pelo Teste de Wricke para as médias dos genótipos na análise conjunta de seis ambientes, referentes aos caracteres NDM (número de dias para a maturidade), APM (altura da planta na maturidade), Ac (acamamento), VA (valor agronômico), CHS (reação ao cancro-da-haste da soja) e PG (produtividade de grãos). Soja, semeaduras em 1995 (ESALQ), 1996 (ESALQ e Anhembi) e 1997 (ESALQ, Anhembi e Areão). Piracicaba, SP. 


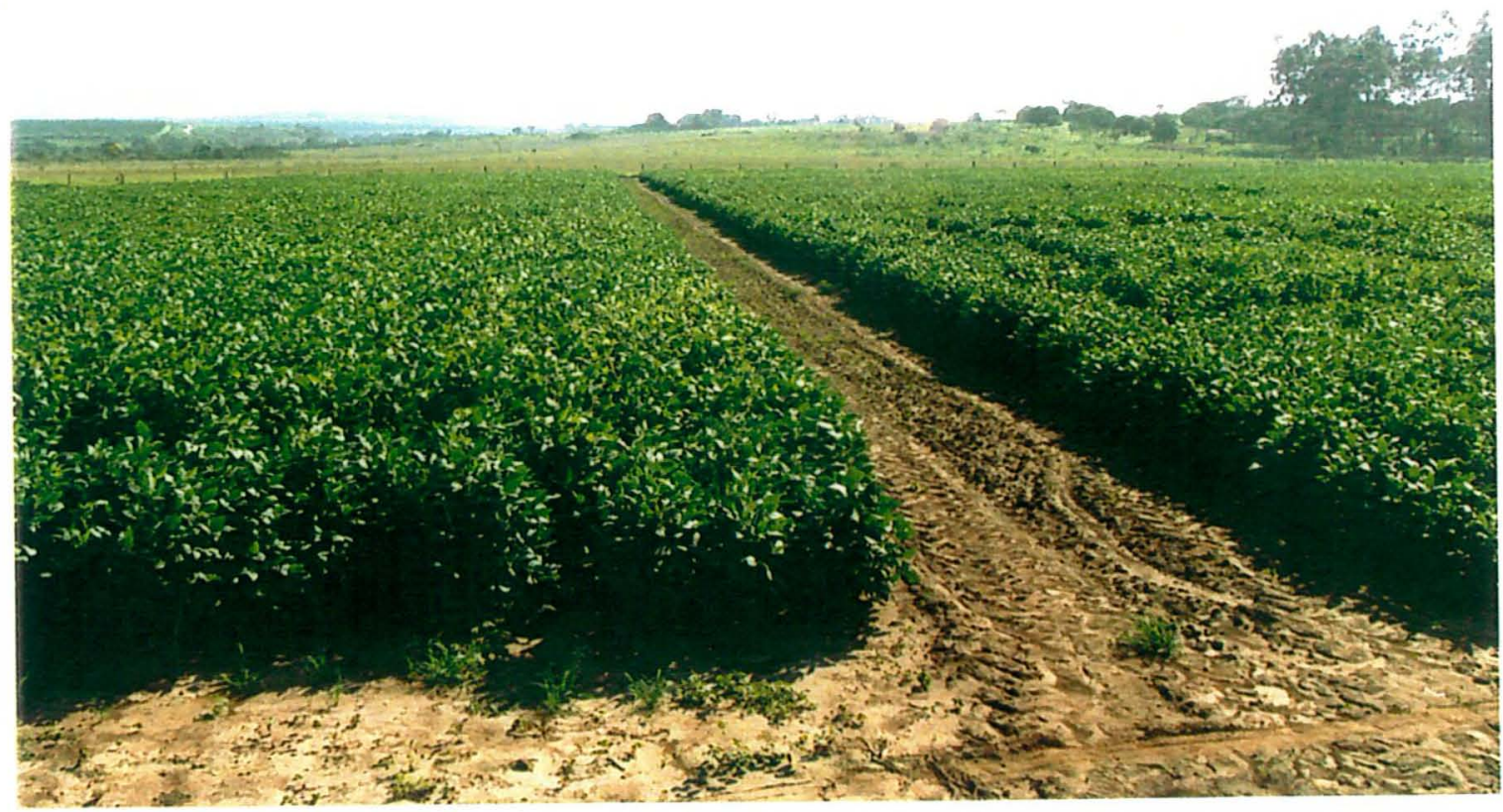

Figura 8. Vista panorâmica dos experimentos conduzidos no local Anhembi. Soja, Piracicaba, SP (semeadura em 25/11/97).

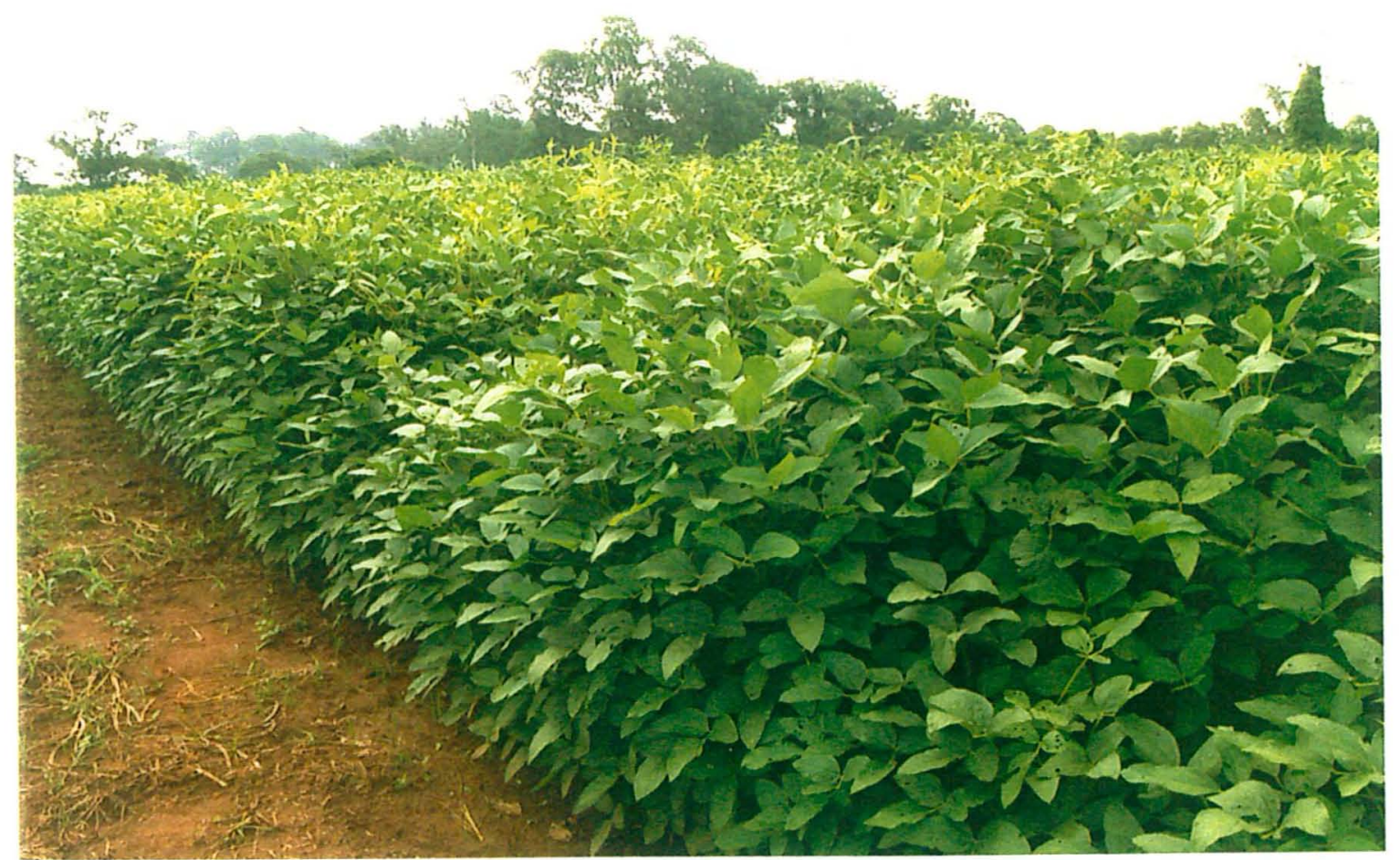

Figura 9. Vista panorâmica dos experimentos conduzidos no local Areão. Soja, Piracicaba, SP (semeadura em 05/11/97). 


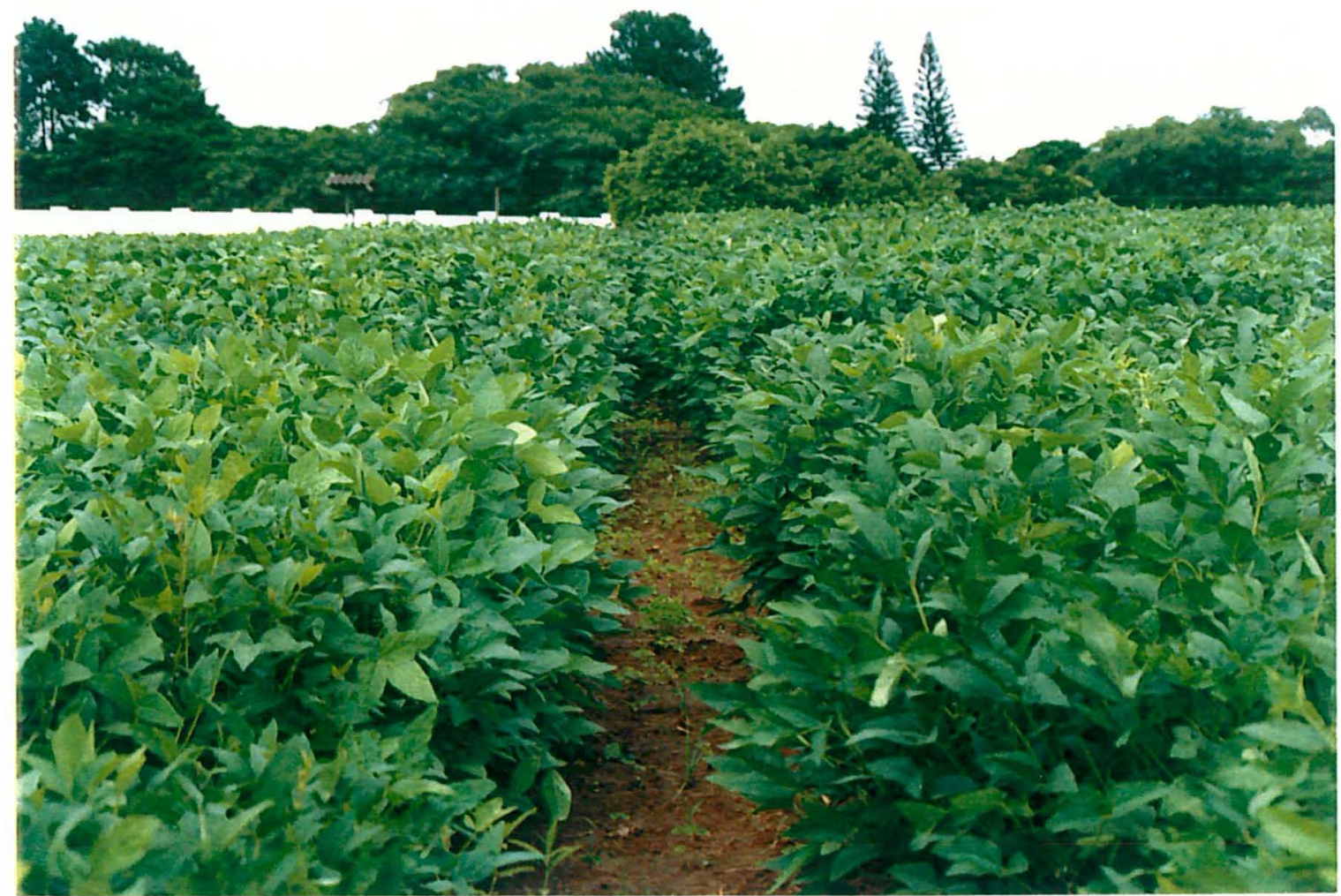

Figura 10. Vista panorâmica dos experimentos conduzidos no local ESALQ. Soja, Piracicaba, SP (semeadura em 12/11/96).

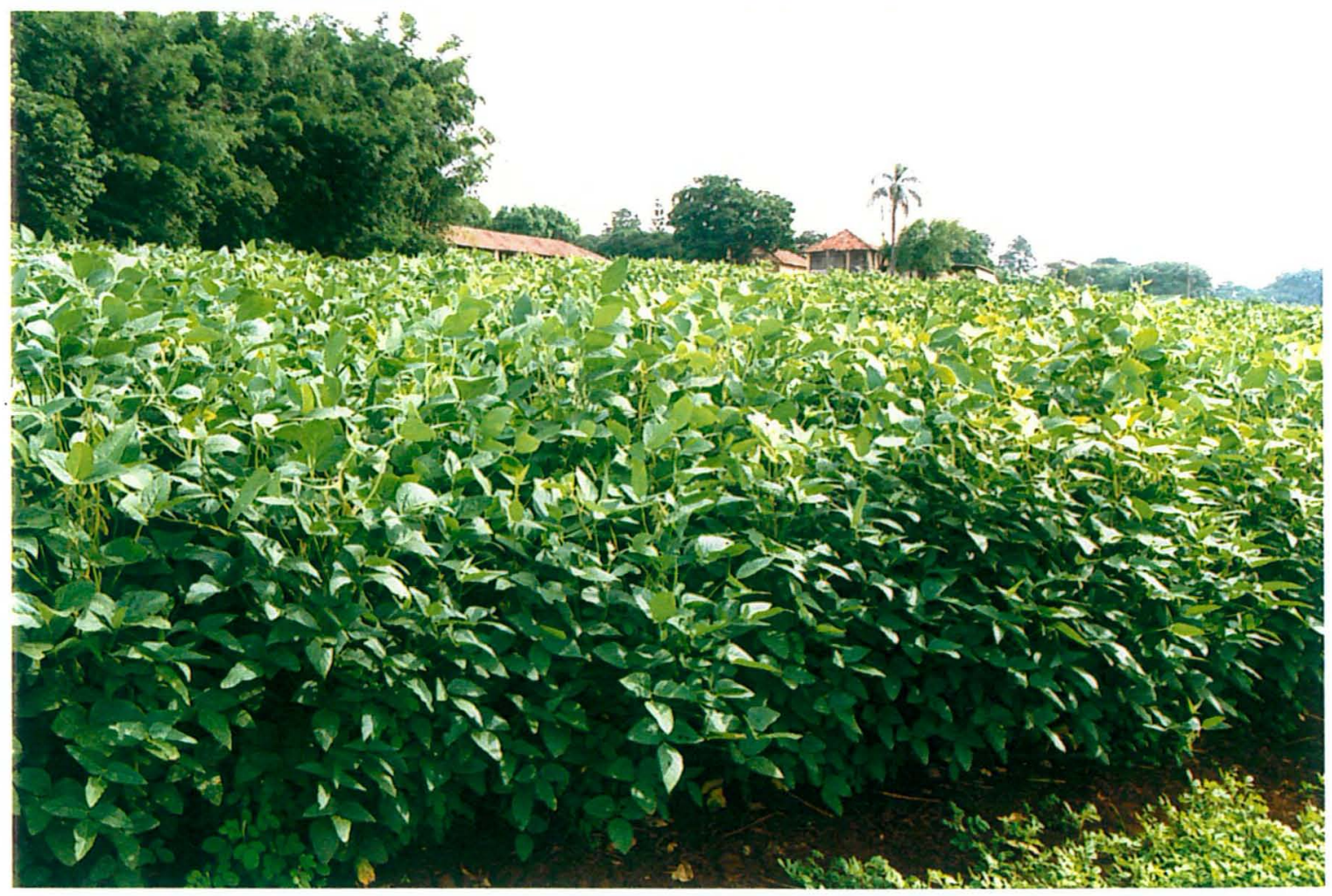

Figura 11. Vista panorâmica dos experimentos conduzidos no local ESALQ. Soja, Piracicaba, SP (semeadura em 12/11/97). 


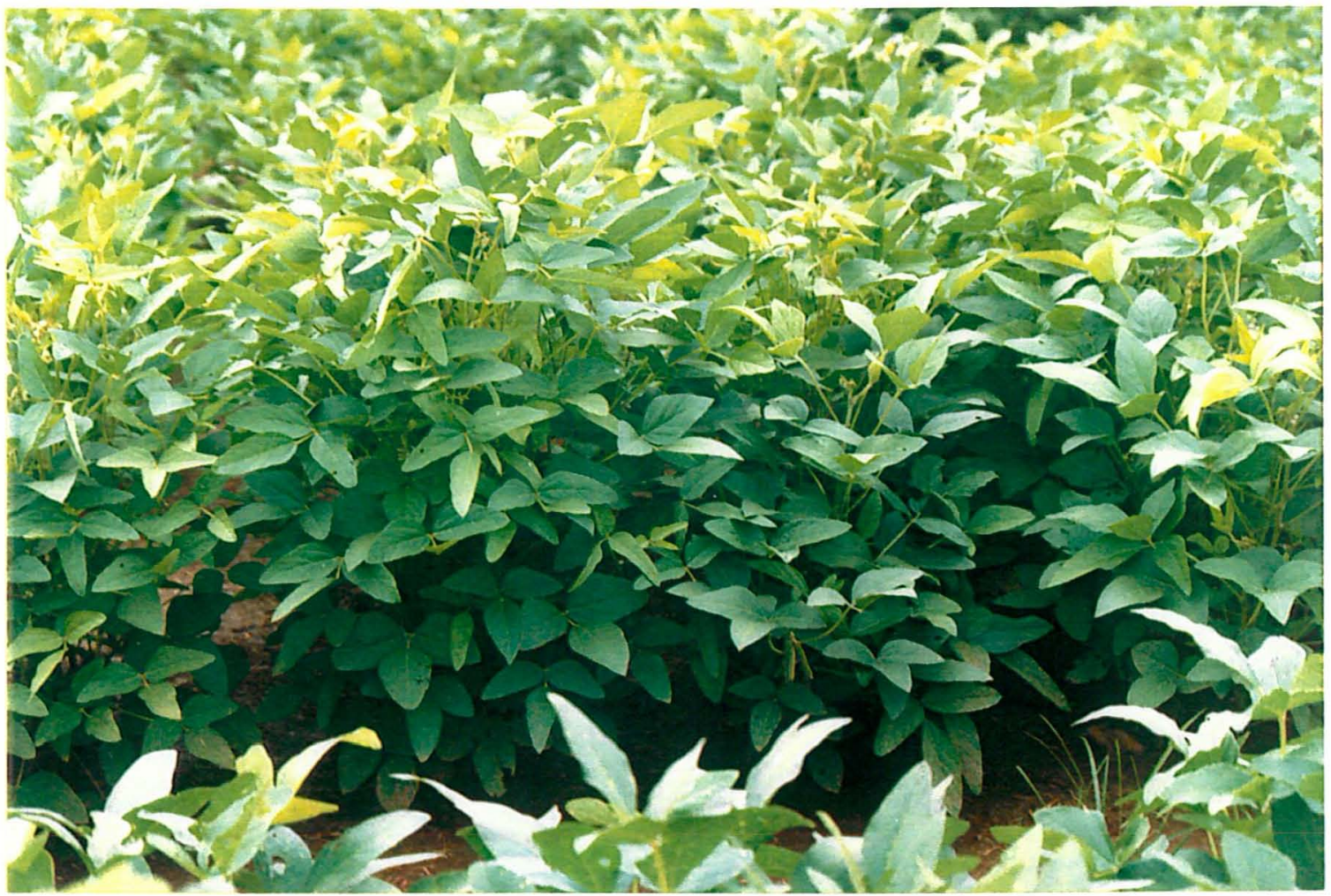

Figura 12. Detalhe de uma parcela de soja, local ESALQ. Piracicaba, SP (semeadura em 12/11/96).

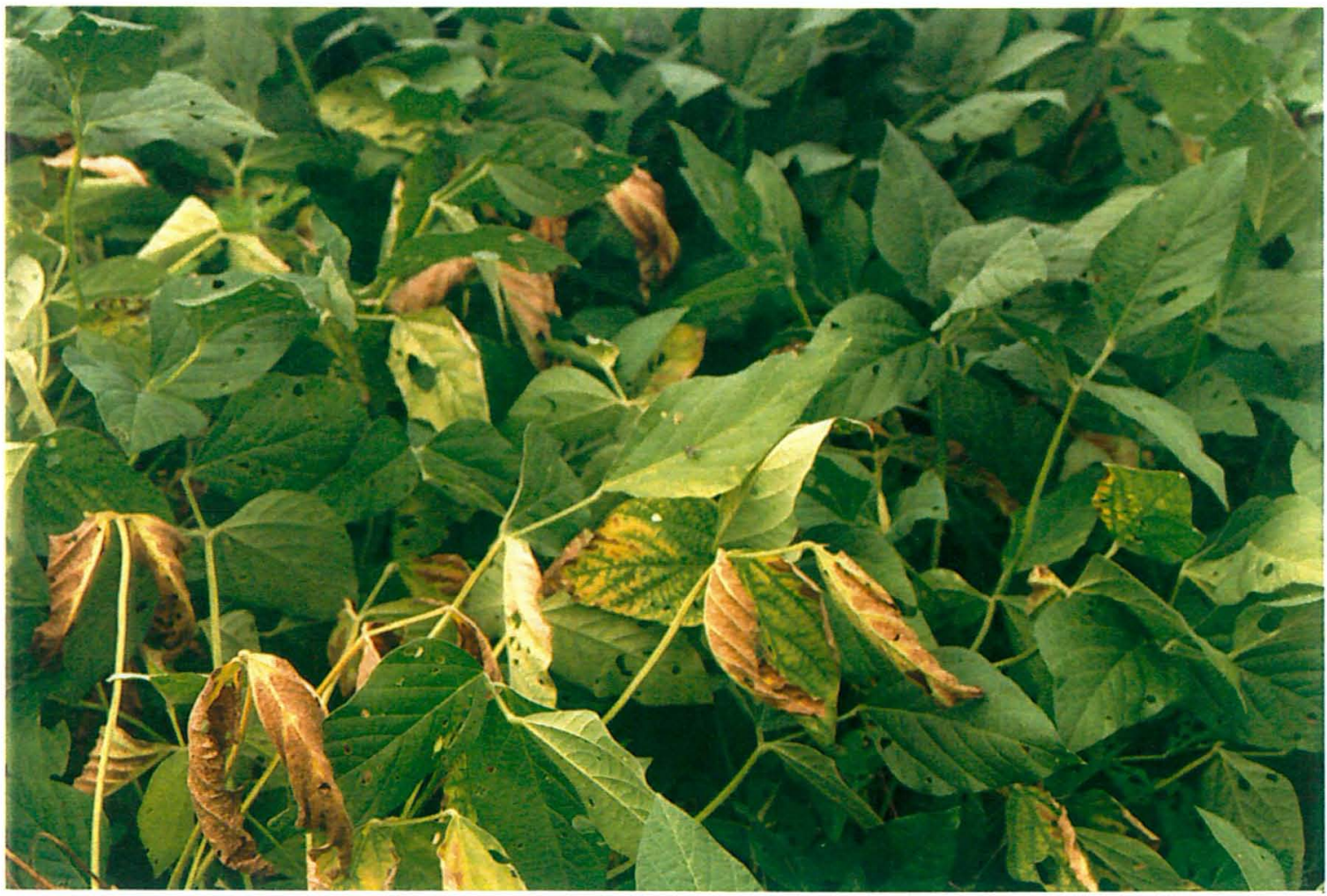

Figura 13. Sintomas de cancro-da-haste da soja no local Areão. Piracicaba, SP (semeadura em 05/11/97). 
APÊNDICES 
Apêndice 1. Relação dos 40 parentais utilizados na síntese dos 60 cruzamentos óctuplos em soja e suas reações de resistência às várias doenças.

\begin{tabular}{|c|c|}
\hline GRUPO PRECOCE & GRUPO SEMI-PRECOCE \\
\hline Parentais & Parentais \\
\hline P01 CEPS-7716 & P11 Bossier \\
\hline P02 Coker 136 & P12 BR-1-Fosca $(\mathrm{R}=1)$ \\
\hline P03 Forrest $(\mathrm{R}=4)$ & P13 Davis \\
\hline P04 FT 81-1835 & P14 FT 81-2706 \\
\hline P05 FT 81-2134 & P15 GO 81-1104 \\
\hline P06 Hale-321 & P16 IAC-1 \\
\hline P07 IAC-Foscarin $31(\mathrm{R}=1)$ & P17 IAC-10 \\
\hline P08 Paraná & P18 IAC-12 $(\mathrm{R}=1,2)$ \\
\hline P09 Primavera $(\mathrm{R}=1)$ & P19 SOC $81-228$ \\
\hline $\mathrm{P} 10 \mathrm{SOC} 81-79(\mathrm{R}=4)$ & P20 Viçoja \\
\hline GRUPO SEMI-TARDIO & GRUPO TARDIO \\
\hline Parentais & Parentais \\
\hline P21 Cristalina $(\mathrm{R}=7,9,12 ; \mathrm{MR}=5)$ & P31 BR-11(Carajás) $(\mathrm{R}=12)$ \\
\hline P22 EMGOPA-301 $(\mathrm{R}=3,12 ; \mathrm{MR}=1,5,7)$ & P32 BR 79-63 \\
\hline P23 IAC-11 $(\mathrm{R}=6,8,9,12 ; \mathrm{MR}=5)$ & P33 GO 79-1039 \\
\hline P24 IAC-4 ( R=8, 11, 12; MR=5, 7, 9, 10) & P34 IAC-2 $(R=1,9 ; M R=5,7)$ \\
\hline P25 IAC-5 $(\mathrm{R}=12 ; \mathrm{MR}=5,7)$ & P35 IAC 80-3006 \\
\hline P26 IAC-6 $(R=12 ; M R=5)$ & P36 Numbaíra $(\mathrm{R}=6,8,9,12 ; \mathrm{MR}=1,5)$ \\
\hline P27 IAC-8 $(\mathrm{R}=2,12 ; \mathrm{MR}=5)$ & P37 Paranagoiana ( $\mathrm{R}=12 ; \mathrm{MR}=5,10)$ \\
\hline P28 IAC-9 $(\mathrm{R}=5,6,12)$ & P38 Timbira $(R=1,5,12 ; M R=7)$ \\
\hline P29 Santa Rosa $(R=1,5,12 ; M R=7)$ & P39 Tropical $(R=2,7,12 ; M R=10)$ \\
\hline P30 SS-1 $(R=9 ; 12 ; M R=5,10)$ & P40 White Biloxi \\
\hline
\end{tabular}

Resistência a doenças:

1: Cancro da Haste (Diaporthe phaseolorum f.sp. meridionalis)

2: Nematóide de Galha (Meloidogyne incognita)

3: Nematóide de Galha (Meloidogyne javanica)

4: Nematóide de Cisto ( Heterodera glycines)

5: Mancha Púrpura (Cercospora kikuchi)

6: Vírus do Mosaico Comum da soja

7: Míldio Pulvurulento ( Peronospora manshurica)

8: Crestamento Bacteriano ( Pseudomonas syringae pv. glycinea)

9: Mancha Olho-de-rã ( Cercospora sojina)

10: Mancha Parda (Septoria glycines)

11: Fusarium

Critérios: R: Resistente; MR: Moderadamente Resistente 
Apêndice 2. Genealogias das 60 populações de cruzamentos óctuplos em soja.

\begin{tabular}{|c|c|}
\hline Número do cruzamento & Genealogias $^{2}$ \\
\hline $\mathrm{C} 01$ & {$[(\mathrm{P} 08 \times \mathrm{P} 09) \times(\mathrm{P} 13 \times \mathrm{P} 14)] \times[(\mathrm{P} 21 \times \mathrm{P} 25) \times(\mathrm{P} 31 \times \mathrm{P} 34)]$} \\
\hline $\mathrm{C} 02$ & {$[(\mathrm{P} 08 \times \mathrm{P} 01) \times(\mathrm{P} 11 \times \mathrm{P} 20)] \times[(\mathrm{P} 21 \times \mathrm{P} 26) \times(\mathrm{P} 31 \times \mathrm{P} 35)]$} \\
\hline $\mathrm{C} 03$ & {$[(\mathrm{P} 08 \times \mathrm{P} 03) \times(\mathrm{P} 11 \times \mathrm{P} 12)] \times[(\mathrm{P} 21 \times \mathrm{P} 27) \times(\mathrm{P} 31 \times \mathrm{P} 36)]$} \\
\hline $\mathrm{C} 04$ & {$[(\mathrm{P} 08 \times \mathrm{P} 04) \times(\mathrm{P} 13 \times \mathrm{P} 16)] \times[(\mathrm{P} 21 \times \mathrm{P} 28) \times(\mathrm{P} 31 \times \mathrm{P} 37)]$} \\
\hline $\mathrm{C} 05$ & {$[(\mathrm{P} 08 \times \mathrm{P} 10) \times(\mathrm{P} 13 \times \mathrm{P} 15)] \times[(\mathrm{P} 21 \times \mathrm{P} 23) \times(\mathrm{P} 31 \times \mathrm{P} 38)]$} \\
\hline $\mathrm{C} 06$ & {$[(\mathrm{P} 08 \times \mathrm{P} 06) \times(\mathrm{P} 13 \times \mathrm{P} 19)] \times[(\mathrm{P} 21 \times \mathrm{P} 29) \times(\mathrm{P} 31 \times \mathrm{P} 39)]$} \\
\hline $\mathrm{C} 07$ & {$[(\mathrm{P} 08 \times \mathrm{P} 05) \times(\mathrm{P} 13 \times \mathrm{P} 17)] \times[(\mathrm{P} 21 \times \mathrm{P} 30) \times(\mathrm{P} 31 \times \mathrm{P} 40)]$} \\
\hline $\mathrm{C} 08$ & {$[(\mathrm{P} 07 \times \mathrm{P} 02) \times(\mathrm{P} 11 \times \mathrm{P} 14)] \times[(\mathrm{P} 22 \times \mathrm{P} 24) \times(\mathrm{P} 32 \times \mathrm{P} 33)]$} \\
\hline $\mathrm{C} 09$ & {$[(\mathrm{P} 07 \times \mathrm{P} 09) \times(\mathrm{P} 11 \times \mathrm{P} 17)] \times[(\mathrm{P} 22 \times \mathrm{P} 25) \times(\mathrm{P} 32 \times \mathrm{P} 34)]$} \\
\hline $\mathrm{C} 10$ & {$[(\mathrm{P} 07 \times \mathrm{P} 01) \times(\mathrm{P} 11 \times \mathrm{P} 18)] \times[(\mathrm{P} 22 \times \mathrm{P} 26) \times(\mathrm{P} 32 \times \mathrm{P} 35)]$} \\
\hline C11 & {$[(\mathrm{P} 07 \times \mathrm{P} 03) \times(\mathrm{P} 11 \times \mathrm{P} 16)] \times[(\mathrm{P} 22 \times \mathrm{P} 27) \times(\mathrm{P} 32 \times \mathrm{P} 36)]$} \\
\hline $\mathrm{C} 12$ & {$[(\mathrm{P} 07 \times \mathrm{P} 04) \times(\mathrm{P} 13 \times \mathrm{P} 12)] \times[(\mathrm{P} 22 \times \mathrm{P} 28) \times(\mathrm{P} 32 \times \mathrm{P} 37)]$} \\
\hline $\mathrm{C} 13$ & {$[(\mathrm{P} 07 \times \mathrm{P} 10) \times(\mathrm{P} 11 \times \mathrm{P} 15)] \times[(\mathrm{P} 22 \times \mathrm{P} 23) \times(\mathrm{P} 32 \times \mathrm{P} 38)]$} \\
\hline C14 & {$[(\mathrm{P} 07 \times \mathrm{P} 06) \times(\mathrm{P} 11 \times \mathrm{P} 19)] \times[(\mathrm{P} 22 \times \mathrm{P} 29) \times(\mathrm{P} 32 \times \mathrm{P} 39)]$} \\
\hline $\mathrm{C} 15$ & {$[(\mathrm{P} 07 \times \mathrm{P} 05) \times(\mathrm{P} 13 \times \mathrm{P} 18)] \times[(\mathrm{P} 22 \times \mathrm{P} 30) \times(\mathrm{P} 32 \times \mathrm{P} 40)]$} \\
\hline $\mathrm{C} 16$ & {$[(\mathrm{P} 02 \times \mathrm{P} 09) \times(\mathrm{P} 20 \times \mathrm{P} 17)] \times[(\mathrm{P} 24 \times \mathrm{P} 25) \times(\mathrm{P} 33 \times \mathrm{P} 34)]$} \\
\hline $\mathrm{C} 17$ & {$[(\mathrm{P} 02 \times \mathrm{P} 01) \times(\mathrm{P} 20 \times \mathrm{P} 18)] \times[(\mathrm{P} 24 \times \mathrm{P} 26) \times(\mathrm{P} 33 \times \mathrm{P} 35)]$} \\
\hline C18 & {$[(\mathrm{P} 02 \times \mathrm{P} 03) \times(\mathrm{P} 20 \times \mathrm{P} 16)] \times[(\mathrm{P} 24 \times \mathrm{P} 27) \times(\mathrm{P} 33 \times \mathrm{P} 36)]$} \\
\hline C19 & {$[(\mathrm{P} 02 \times \mathrm{P} 04) \times(\mathrm{P} 20 \times \mathrm{P} 12)] \times[(\mathrm{P} 24 \times \mathrm{P} 28) \times(\mathrm{P} 33 \times \mathrm{P} 37)]$} \\
\hline $\mathrm{C} 20$ & {$[(\mathrm{P} 02 \times \mathrm{P} 05) \times(\mathrm{P} 20 \times \mathrm{P} 14)] \times[(\mathrm{P} 24 \times \mathrm{P} 30) \times(\mathrm{P} 33 \times \mathrm{P} 40)]$} \\
\hline $\mathrm{C} 21$ & {$[(\mathrm{P} 09 \times \mathrm{P} 01) \times(\mathrm{P} 17 \times \mathrm{P} 18)] \times[(\mathrm{P} 25 \times \mathrm{P} 26) \times(\mathrm{P} 39 \times \mathrm{P} 40)]$} \\
\hline $\mathrm{C} 22$ & {$[(\mathrm{P} 09 \times \mathrm{P} 03) \times(\mathrm{P} 17 \times \mathrm{P} 12)] \times[(\mathrm{P} 25 \times \mathrm{P} 27) \times(\mathrm{P} 39 \times \mathrm{P} 36)]$} \\
\hline $\mathrm{C} 23$ & {$[(\mathrm{P} 09 \times \mathrm{P} 04) \times(\mathrm{P} 17 \times \mathrm{P} 16)] \times[(\mathrm{P} 25 \times \mathrm{P} 28) \times(\mathrm{P} 39 \times \mathrm{P} 37)]$} \\
\hline $\mathrm{C} 24$ & {$[(\mathrm{P} 09 \times \mathrm{P} 10) \times(\mathrm{P} 17 \times \mathrm{P} 15)] \times[(\mathrm{P} 25 \times \mathrm{P} 23) \times(\mathrm{P} 39 \times \mathrm{P} 38)]$} \\
\hline $\mathrm{C} 25$ & {$[(\mathrm{P} 09 \times \mathrm{P} 06) \times(\mathrm{P} 17 \times \mathrm{P} 14)] \times[(\mathrm{P} 25 \times \mathrm{P} 29) \times(\mathrm{P} 39 \times \mathrm{P} 34)]$} \\
\hline $\mathrm{C} 26$ & {$[(\mathrm{P} 09 \times \mathrm{P} 05) \times(\mathrm{P} 17 \times \mathrm{P} 19)] \times[(\mathrm{P} 25 \times \mathrm{P} 30) \times(\mathrm{P} 39 \times \mathrm{P} 35)]$} \\
\hline $\mathrm{C} 27$ & {$[(\mathrm{P} 01 \times \mathrm{P} 03) \times(\mathrm{P} 18 \times \mathrm{P} 16)] \times[(\mathrm{P} 26 \times \mathrm{P} 27) \times(\mathrm{P} 40 \times \mathrm{P} 36)]$} \\
\hline C28 & {$[(\mathrm{P} 01 \times \mathrm{P} 04) \times(\mathrm{P} 18 \times \mathrm{P} 12)] \times[(\mathrm{P} 26 \times \mathrm{P} 28) \times(\mathrm{P} 40 \times \mathrm{P} 37)]$} \\
\hline $\mathrm{C} 29$ & {$[(\mathrm{P} 01 \times \mathrm{P} 10) \times(\mathrm{P} 18 \times \mathrm{P} 15)] \times[(\mathrm{P} 26 \times \mathrm{P} 23) \times(\mathrm{P} 40 \times \mathrm{P} 38)]$} \\
\hline $\mathrm{C} 30$ & {$[(\mathrm{P} 01 \times \mathrm{P} 06) \times(\mathrm{P} 18 \times \mathrm{P} 14)] \times[(\mathrm{P} 26 \times \mathrm{P} 29) \times(\mathrm{P} 40 \times \mathrm{P} 34)]$} \\
\hline C31 & {$[(\mathrm{P} 01 \times \mathrm{P} 05) \times(\mathrm{P} 18 \times \mathrm{P} 19)] \times[(\mathrm{P} 26 \times \mathrm{P} 30) \times(\mathrm{P} 40 \times \mathrm{P} 35)]$} \\
\hline $\mathrm{C} 32$ & {$[(\mathrm{P} 03 \times \mathrm{P} 10) \times(\mathrm{P} 16 \times \mathrm{P} 15)] \times[(\mathrm{P} 27 \times \mathrm{P} 23) \times(\mathrm{P} 37 \times \mathrm{P} 38)]$} \\
\hline $\mathrm{C} 33$ & {$[(\mathrm{P} 03 \times \mathrm{P} 06) \times(\mathrm{P} 16 \times \mathrm{P} 14)] \times[(\mathrm{P} 27 \times \mathrm{P} 29) \times(\mathrm{P} 37 \times \mathrm{P} 35)]$} \\
\hline
\end{tabular}


Continuação...

Apêndice 2. Genealogias das 60 populações de cruzamentos óctuplos em soja.

\begin{tabular}{|c|c|}
\hline Número do cruzamento & Genealogias $^{\mathrm{a}}$ \\
\hline $\mathrm{C} 34$ & {$[(\mathrm{P} 04 \times \mathrm{P} 10) \times(\mathrm{P} 12 \times \mathrm{P} 14)] \times[(\mathrm{P} 28 \times \mathrm{P} 23) \times(\mathrm{P} 36 \times \mathrm{P} 38)]$} \\
\hline $\mathrm{C} 35$ & {$[(\mathrm{P} 04 \times \mathrm{P} 06) \times(\mathrm{P} 15 \times \mathrm{P} 14)] \times[(\mathrm{P} 28 \times \mathrm{P} 29) \times(\mathrm{P} 34 \times \mathrm{P} 37)]$} \\
\hline $\mathrm{C} 36$ & {$[(\mathrm{P} 04 \times \mathrm{P} 05) \times(\mathrm{P} 12 \times \mathrm{P} 19)] \times[(\mathrm{P} 28 \times \mathrm{P} 30) \times(\mathrm{P} 34 \times \mathrm{P} 36)]$} \\
\hline $\mathrm{C} 37$ & {$[(\mathrm{P} 10 \times \mathrm{P} 06) \times(\mathrm{P} 19 \times \mathrm{P} 14)] \times[(\mathrm{P} 23 \times \mathrm{P} 29) \times(\mathrm{P} 34 \times \mathrm{P} 38)]$} \\
\hline $\mathrm{C} 38$ & {$[(\mathrm{P} 10 \times \mathrm{P} 05) \times(\mathrm{P} 12 \times \mathrm{P} 15)] \times[(\mathrm{P} 23 \times \mathrm{P} 30) \times(\mathrm{P} 35 \times \mathrm{P} 38)]$} \\
\hline C39 & {$[(\mathrm{P} 06 \times \mathrm{P} 05) \times(\mathrm{P} 15 \times \mathrm{P} 19)] \times[(\mathrm{P} 29 \times \mathrm{P} 30) \times(\mathrm{P} 34 \times \mathrm{P} 35)]$} \\
\hline $\mathrm{C} 40$ & {$[(\mathrm{P} 08 \times \mathrm{P} 04) \times(\mathrm{P} 13 \times \mathrm{P} 16)] \times[(\mathrm{P} 21 \times \mathrm{P} 23) \times(\mathrm{P} 31 \times \mathrm{P} 38)]$} \\
\hline $\mathrm{C} 41$ & {$[(\mathrm{P} 07 \times \mathrm{P} 01) \times(\mathrm{P} 11 \times \mathrm{P} 18)] \times[(\mathrm{P} 21 \times \mathrm{P} 29) \times(\mathrm{P} 31 \times \mathrm{P} 39)]$} \\
\hline $\mathrm{C} 42$ & {$[(\mathrm{P} 07 \times \mathrm{P} 04) \times(\mathrm{P} 13 \times \mathrm{P} 12)] \times[(\mathrm{P} 24 \times \mathrm{P} 25) \times(\mathrm{P} 33 \times \mathrm{P} 34)]$} \\
\hline $\mathrm{C} 43$ & {$[(\mathrm{P} 07 \times \mathrm{P} 06) \times(\mathrm{P} 11 \times \mathrm{P} 19)] \times[(\mathrm{P} 22 \times \mathrm{P} 28) \times(\mathrm{P} 32 \times \mathrm{P} 37)]$} \\
\hline $\mathrm{C} 44$ & {$[(\mathrm{P} 09 \times \mathrm{P} 04) \times(\mathrm{P} 17 \times \mathrm{P} 16)] \times[(\mathrm{P} 24 \times \mathrm{P} 23) \times(\mathrm{P} 33 \times \mathrm{P} 38)]$} \\
\hline $\mathrm{C} 45$ & {$[(\mathrm{P} 09 \times \mathrm{P} 01) \times(\mathrm{P} 17 \times \mathrm{P} 18)] \times[(\mathrm{P} 24 \times \mathrm{P} 29) \times(\mathrm{P} 33 \times \mathrm{P} 39)]$} \\
\hline $\mathrm{C} 46$ & {$[(\mathrm{P} 09 \times \mathrm{P} 03) \times(\mathrm{P} 17 \times \mathrm{P} 12)] \times[(\mathrm{P} 25 \times \mathrm{P} 26) \times(\mathrm{P} 39 \times \mathrm{P} 40)]$} \\
\hline $\mathrm{C} 47$ & {$[(\mathrm{P} 09 \times \mathrm{P} 01) \times(\mathrm{P} 17 \times \mathrm{P} 18)] \times[(\mathrm{P} 26 \times \mathrm{P} 29) \times(\mathrm{P} 34 \times \mathrm{P} 40)]$} \\
\hline $\mathrm{C} 48$ & {$[(\mathrm{P} 09 \times \mathrm{P} 03) \times(\mathrm{P} 17 \times \mathrm{P} 12)] \times[(\mathrm{P} 27 \times \mathrm{P} 30) \times(\mathrm{P} 35 \times \mathrm{P} 39)]$} \\
\hline C49 & {$[(\mathrm{P} 07 \times \mathrm{P} 03) \times(\mathrm{P} 11 \times \mathrm{P} 16)] \times[(\mathrm{P} 21 \times \mathrm{P} 26) \times(\mathrm{P} 31 \times \mathrm{P} 35)]$} \\
\hline C50 & {$[(\mathrm{P} 02 \times \mathrm{P} 04) \times(\mathrm{P} 20 \times \mathrm{P} 12)] \times[(\mathrm{P} 26 \times \mathrm{P} 27) \times(\mathrm{P} 36 \times \mathrm{P} 40)]$} \\
\hline C51 & {$[(\mathrm{P} 09 \times \mathrm{P} 03) \times(\mathrm{P} 17 \times \mathrm{P} 12)] \times[(\mathrm{P} 24 \times \mathrm{P} 29) \times(\mathrm{P} 33 \times \mathrm{P} 39)]$} \\
\hline C52 & {$[(\mathrm{P} 01 \times \mathrm{P} 03) \times(\mathrm{P} 18 \times \mathrm{P} 16)] \times[(\mathrm{P} 24 \times \mathrm{P} 29) \times(\mathrm{P} 33 \times \mathrm{P} 39)]$} \\
\hline C53 & {$[(\mathrm{P} 02 \times \mathrm{P} 06) \times(\mathrm{P} 20 \times \mathrm{P} 14)] \times[(\mathrm{P} 24 \times \mathrm{P} 28) \times(\mathrm{P} 33 \times \mathrm{P} 37)]$} \\
\hline $\mathrm{C} 54$ & {$[(\mathrm{P} 03 \times \mathrm{P} 05) \times(\mathrm{P} 16 \times \mathrm{P} 19)] \times[(\mathrm{P} 24 \times \mathrm{P} 30) \times(\mathrm{P} 33 \times \mathrm{P} 40)]$} \\
\hline C55 & {$[(\mathrm{P} 03 \times \mathrm{P} 06) \times(\mathrm{P} 16 \times \mathrm{P} 14)] \times[(\mathrm{P} 27 \times \mathrm{P} 30) \times(\mathrm{P} 35 \times \mathrm{P} 39)]$} \\
\hline C56 & {$[(\mathrm{P} 02 \times \mathrm{P} 03) \times(\mathrm{P} 20 \times \mathrm{P} 16)] \times[(\mathrm{P} 27 \times \mathrm{P} 28) \times(\mathrm{P} 36 \times \mathrm{P} 37)]$} \\
\hline C57 & {$[(\mathrm{P} 07 \times \mathrm{P} 03) \times(\mathrm{P} 11 \times \mathrm{P} 16)] \times[(\mathrm{P} 21 \times \mathrm{P} 27) \times(\mathrm{P} 31 \times \mathrm{P} 36)]$} \\
\hline C58 & {$[(\mathrm{P} 08 \times \mathrm{P} 10) \times(\mathrm{P} 13 \times \mathrm{P} 15)] \times[(\mathrm{P} 21 \times \mathrm{P} 22) \times(\mathrm{P} 31 \times \mathrm{P} 32)]$} \\
\hline C59 & {$[(\mathrm{P} 08 \times \mathrm{P} 04) \times(\mathrm{P} 13 \times \mathrm{P} 16)] \times[(\mathrm{P} 21 \times \mathrm{P} 26) \times(\mathrm{P} 31 \times \mathrm{P} 35)]$} \\
\hline C60 & {$[(\mathrm{P} 06 \times \mathrm{P} 05) \times(\mathrm{P} 15 \times \mathrm{P} 19)] \times[(\mathrm{P} 23 \times \mathrm{P} 29) \times(\mathrm{P} 34 \times \mathrm{P} 38)]$} \\
\hline
\end{tabular}

\footnotetext{
: os 40 parentais (P01 a P40) envolvidos nas genealogias estão identificados no Apêndice 1.
} 


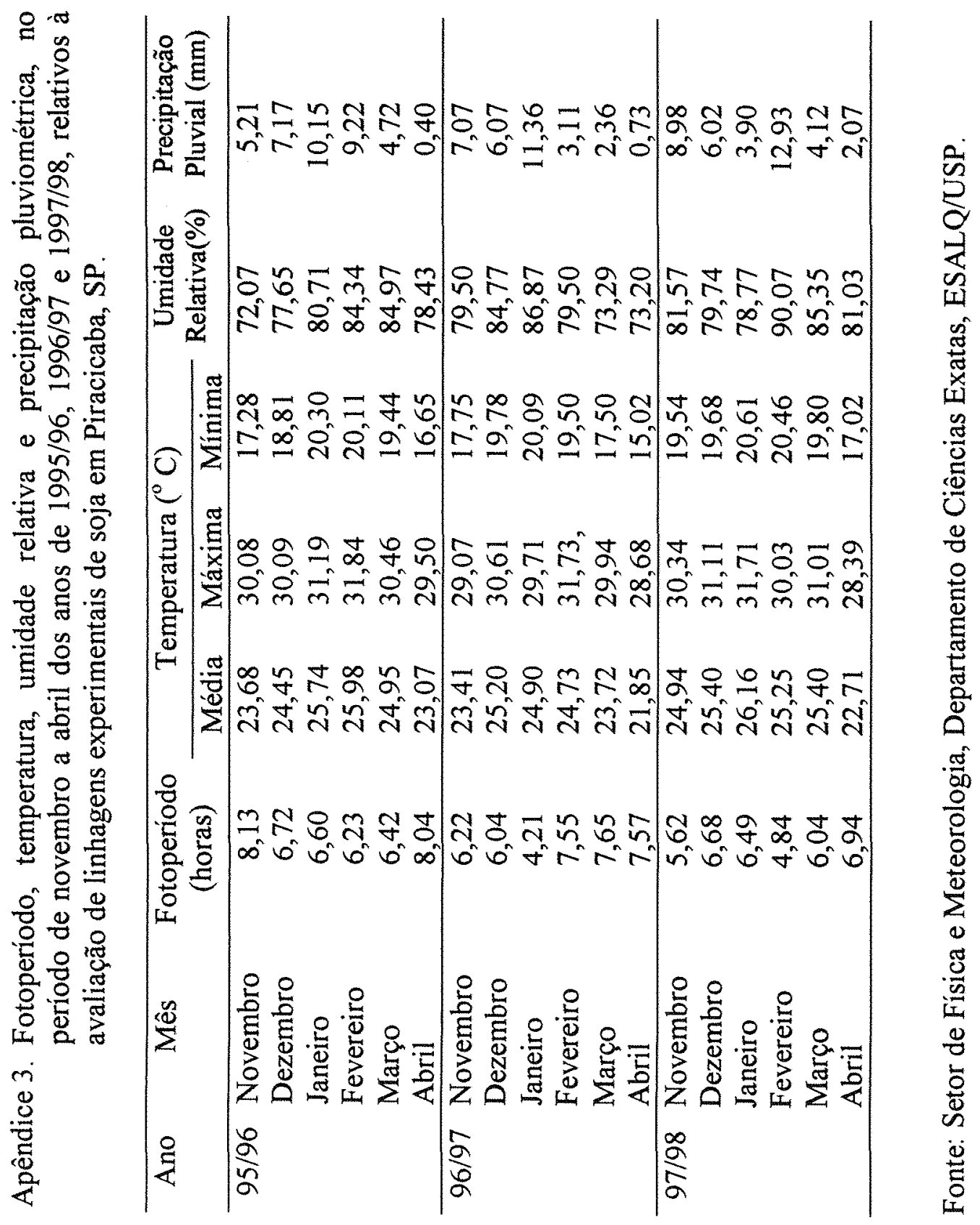




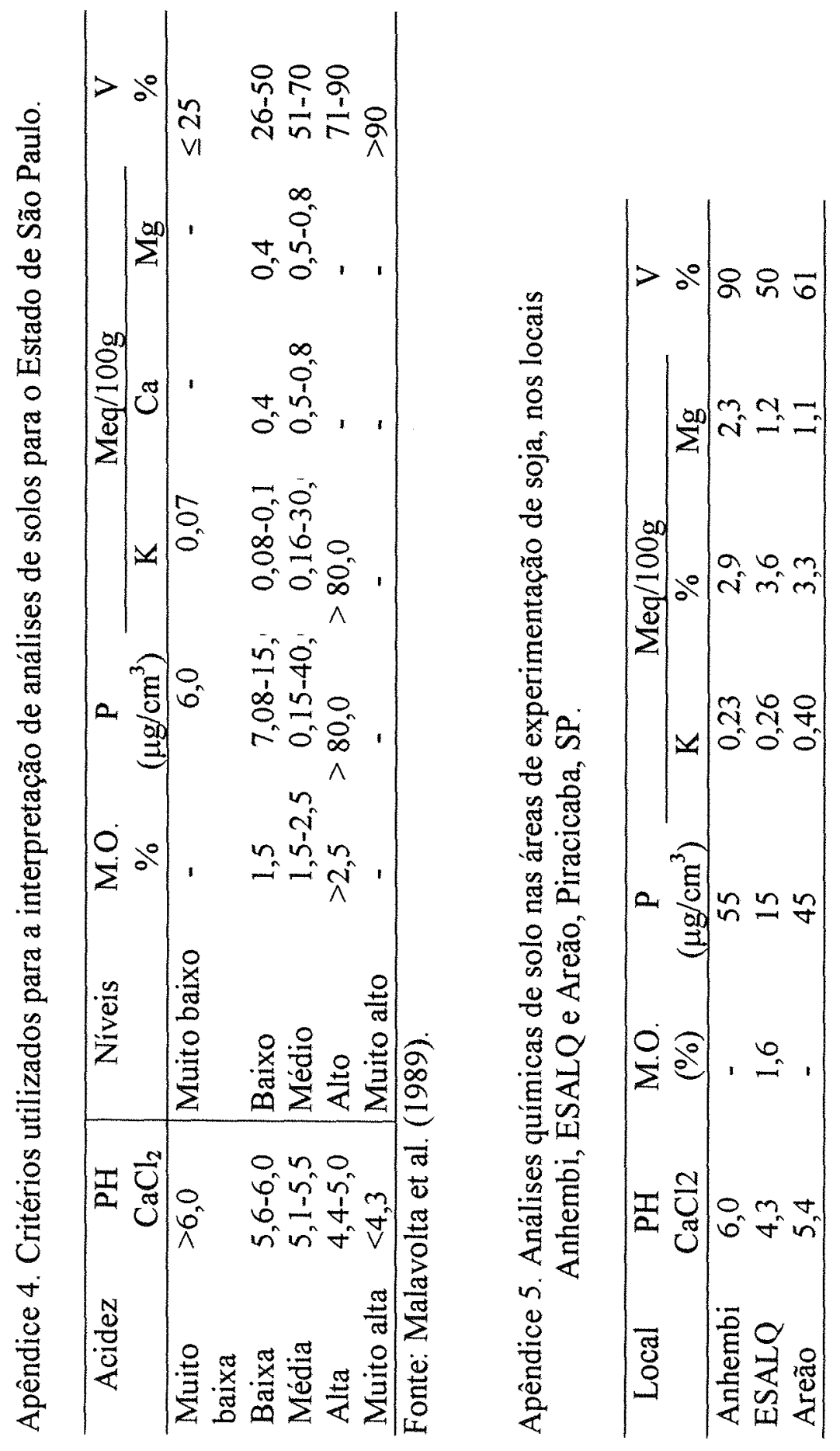


Apêndice 6. Esquema de análise de variância individual para as testemunhas em blocos ao acaso, com repetições subdivididas em conjuntos experimentais, ao nivel de parcelas, e respectivas esperanças matemáticas dos quadrados médios.

\begin{tabular}{|c|c|c|c|c|}
\hline FV & $\mathbf{G L}$ & $\mathbf{E}(\mathbf{Q M})$ & $\mathbf{Q M}$ & $\mathbf{F}$ \\
\hline Conjuntos(C) & $\mathrm{c}-1$ & $\sigma_{\mathrm{e}}^{2}+T \sigma_{\mathrm{c}}^{2}$ & $\mathrm{Q}_{1}$ & $\mathrm{Q}_{1} / \mathrm{Q}_{3}$ \\
\hline Testemunhas(T) & $\mathrm{t}-1$ & $\sigma_{e}^{2}+C V_{t}$ & $\mathrm{Q}_{2}$ & $\mathrm{Q}_{2} / \mathrm{Q}_{3}$ \\
\hline Resíduo & $(\mathrm{c}-1)(\mathrm{t}-1)$ & $\sigma_{e}^{2}$ & $\mathrm{Q}_{3}$ & \\
\hline Total & (ct) -1 & & & \\
\hline
\end{tabular}

Apêndice 7. Esquema de análise de variância por ano para as testemunhas em blocos ao acaso, com repetições subdivididas em conjuntos experimentais, ao nivel de parcelas, e respectivas esperanças matemáticas dos quadrados médios.

\begin{tabular}{|c|c|c|c|c|}
\hline FV & GL & $\mathbf{E}(\mathbf{Q M})$ & $\mathbf{Q M}$ & $\mathbf{F}$ \\
\hline Locais (L) & $1-1$ & $\sigma_{\mathrm{e}}^{2}+\sigma_{\mathrm{ctl}}^{2}+\mathrm{T} \sigma_{\mathrm{c} / 1}^{2}+\mathrm{CV}_{\mathrm{lt}}+\mathrm{CTV} \mathrm{V}_{\mathrm{l}}$ & $\mathrm{Q}_{1}$ & $\mathrm{Q}_{1}+\mathrm{Q}_{5} / \mathrm{Q}_{3}+\mathrm{Q}_{4}$ \\
\hline Testemunhas(T) & $t-1$ & $\sigma_{\mathrm{e}}^{2}+\sigma_{\mathrm{ctl}}^{2}+L \sigma_{\mathrm{ct}}^{2}+\mathrm{CV}_{\mathrm{tt}}+\mathrm{LCV}_{\mathrm{t}}$ & $\mathrm{Q}_{2}$ & $\mathrm{Q}_{2}+\mathrm{Q}_{6} / \mathrm{Q}_{3}+\mathrm{Q}_{5}$ \\
\hline $\mathrm{L} \times \mathrm{T}$ & $(1-1)(t-1)$ & $\sigma_{\mathrm{e}}^{2}+\sigma_{\mathrm{ctl}}^{2}+\mathrm{CV}_{\mathrm{tt}}$ & $\mathrm{Q}_{3}$ & $\mathrm{Q}_{3} / \mathrm{Q}_{6}$ \\
\hline Conjuntos(C)/L & $(\mathrm{c}-1) 1$ & $\sigma_{\mathrm{e}}^{2}+\sigma_{\mathrm{ctl}}^{2}+L \sigma_{\mathrm{ct}}^{2}+T \sigma_{\mathrm{c} / 1}^{2}$ & $\mathrm{Q}_{4}$ & $\mathrm{Q}_{4} / \mathrm{Q}_{5}$ \\
\hline $\mathrm{C} \times \mathrm{T}$ & $(\mathrm{c}-1)(\mathrm{t}-1)$ & $\sigma_{\mathrm{e}}^{2}+\sigma_{\mathrm{ctl}}^{2}+L \sigma_{\mathrm{ct}}^{2}$ & $Q_{5}$ & $\mathrm{Q}_{5} / \mathrm{Q}_{6}$ \\
\hline Resíduo (C x T x L) & $(\mathrm{c}-1)(\mathrm{t}-1)(\mathrm{l}-1)$ & $\sigma_{\mathrm{e}}^{2}+\sigma_{\mathrm{etl}}^{2}$ & $\mathrm{Q}_{6}$ & \\
\hline Total & (ltc)-1 & & & \\
\hline
\end{tabular}




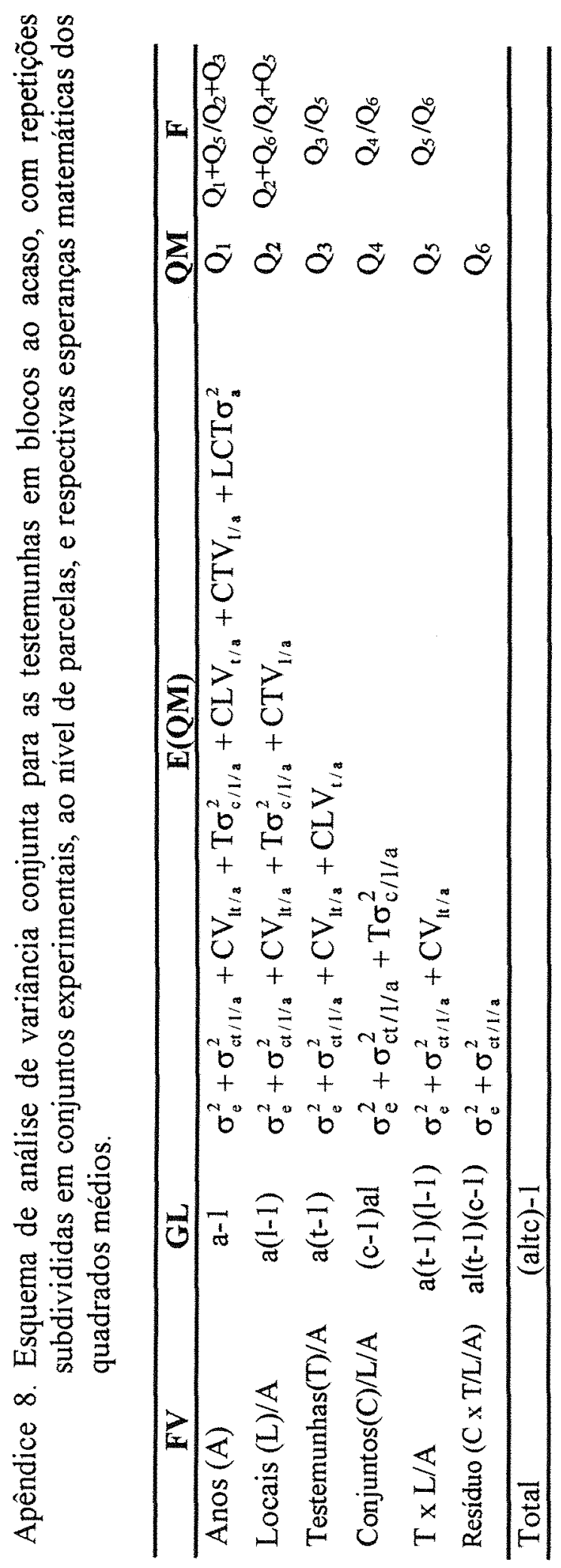


Apêndice 9. Esquema de análise de variância em blocos aumentados de Federer, para os tratamentos, ao nivel de parcelas, e respectivas esperanças matemáticas dos quadrados médios.

\begin{tabular}{lclccc}
\hline \multicolumn{1}{c}{$\mathbf{F V}$} & $\mathbf{G L}$ & & $\mathbf{E}(\mathbf{Q M})$ & $\mathbf{Q M}$ & $\mathbf{F}$ \\
\hline Repetições (R) & $\mathrm{r}-1$ & & -- & $\mathrm{Q}_{1}$ & $\mathrm{Q}_{1} / \mathrm{Q}_{6}$ \\
Tratamentos (G) & $\mathrm{g}-1$ & $\sigma_{\mathrm{e}}^{2}+\mathrm{V}_{\mathrm{g}}$ & & $\mathrm{Q}_{2}$ & $\mathrm{Q}_{2} / \mathrm{Q}_{6}$ \\
Progênies(P) & $\mathrm{p}-1$ & $\sigma_{\mathrm{e}}^{2}+\mathrm{V}_{\mathrm{p}}$ & $\mathrm{Q}_{3}$ & $\mathrm{Q}_{3} / \mathrm{Q}_{6}$ \\
Testemunhas (T) & $\mathrm{t}-1$ & $\sigma_{\mathrm{e}}^{2}+\mathrm{RV}_{\mathrm{t}}$ & & $\mathrm{Q}_{4}$ & $\mathrm{Q}_{4} / \mathrm{Q}_{6}$ \\
P vs T & 1 & & $-\cdots$ & $\mathrm{Q}_{5}$ & $\mathrm{Q}_{5} / \mathrm{Q}_{6}$ \\
Residuo & $\mathrm{t}(\mathrm{r}-1)$ & $\sigma_{\mathrm{e}}^{2}$ & & $\mathrm{Q}_{6}$ & \\
\hline
\end{tabular}

Total (rgpt)-1

Apêndice 10. Esquema de análise de variância individual em blocos ao acaso, para as progênies , ao nível de parcelas, e respectivas esperanças matemáticas dos quadrados médios.

\begin{tabular}{lcllll}
\hline \multicolumn{1}{c}{ FV } & GL & & E(QM) & QM & F \\
\hline Repetições (R) & $\mathrm{r}-1$ & $\sigma_{\mathrm{e}}^{2}+\mathrm{P \sigma}_{\mathrm{r}}^{2}$ & $\mathrm{Q}_{1}$ & $\mathrm{Q}_{1} / \mathrm{Q}_{3}$ \\
Progênies(P) & $\mathrm{p}-1$ & $\sigma_{\mathrm{e}}^{2}+\mathrm{RV}$ & $\mathrm{Q}_{2}$ & $\mathrm{Q}_{2} / \mathrm{Q}_{3}$ \\
Resíduo & $(\mathrm{r}-1)(\mathrm{p}-1)$ & $\sigma_{\mathrm{e}}^{2}$ & $\mathrm{Q}_{3}$ & \\
\hline Total & $(\mathrm{rp})-1$ & & & \\
\hline
\end{tabular}


Apêndice 11. Esquema de análise de variância por ano em blocos ao acaso, para as progênies, ao nivel de parcelas, e respectivas esperanças matemáticas dos quadrados médios.

\begin{tabular}{lclcc}
\hline \multicolumn{1}{c}{$\mathbf{F V}$} & $\mathbf{G L}$ & \multicolumn{1}{c}{$\mathbf{E}(\mathbf{Q M})$} & $\mathbf{Q M}$ & $\mathbf{F}$ \\
\hline Locais (L) & $\mathrm{l}-1$ & $\sigma_{\mathrm{e}}^{2}+\mathrm{RV}_{\mathrm{pl}}+\mathrm{P \sigma}_{\mathrm{r} / \mathrm{l}}^{2}+\mathrm{RPV}_{\mathrm{l}}$ & $\mathrm{Q}_{1}$ & $\mathrm{Q}_{1}+\mathrm{Q}_{8} / \mathrm{Q}_{2}+\mathrm{Q}_{7}$ \\
Repetições (R)/L & $\mathrm{l}(\mathrm{r}-1)$ & $\sigma_{\mathrm{e}}^{2}+\mathrm{P \sigma}_{\mathrm{r} / 1}^{2}$ & $\mathrm{Q}_{2}$ & $\mathrm{Q}_{2} / \mathrm{Q}_{8}$ \\
Tratamentos (G) & $\mathrm{g}-1$ & $\sigma_{\mathrm{e}}^{2}+\mathrm{RV}_{\mathrm{gl}}+\mathrm{RLV}_{\mathrm{g}}$ & $\mathrm{Q}_{3}$ & $\mathrm{Q}_{3} / \mathrm{Q}_{7}$ \\
Progênies(P) & $\mathrm{p}-1$ & $\sigma_{\mathrm{e}}^{2}+\mathrm{RV}_{\mathrm{pl}}+\mathrm{RLV}_{\mathrm{p}}$ & $\mathrm{Q}_{4}$ & $\mathrm{Q}_{4} / \mathrm{Q}_{7}$ \\
Testemunhas (T) & $\mathrm{t}-1$ & $\sigma_{\mathrm{e}}^{2}+\mathrm{RV}_{\mathrm{tl}}+\mathrm{RLV}$ & $\mathrm{Q}_{5}$ & $\mathrm{Q}_{5} / \mathrm{Q}_{7}$ \\
P vs T & 1 & $\sigma_{\mathrm{e}}^{2}+\mathrm{RV}_{\mathrm{tpl}}+\mathrm{RLV}_{\mathrm{tp}}$ & $\mathrm{Q}_{6}$ & $\mathrm{Q}_{6} / \mathrm{Q}_{7}$ \\
GxL & $(\mathrm{g}-1)(\mathrm{l}-1)$ & $\sigma_{\mathrm{e}}^{2}+\mathrm{RV}_{\mathrm{gl}}$ & $\mathrm{Q}_{7}$ & $\mathrm{Q}_{7} / \mathrm{Q}_{8}$ \\
Resíduo & $\mathrm{l}(\mathrm{g}-1)(\mathrm{r}-1)$ & $\sigma_{\mathrm{e}}^{2}$ & $\mathrm{Q}_{8}$ & \\
\hline Total & $(\operatorname{lrgpt})-1$ & & & \\
\hline
\end{tabular}

Apêndice 12. Esquema de análise de variância conjunta em blocos ao acaso, para as linhagens, ao nivel de parcelas, e respectivas esperanças matemáticas dos quadrados médios.

\begin{tabular}{|c|c|c|c|c|}
\hline FV & GL & $\mathbf{E}(\mathbf{Q M})$ & QM & $\mathbf{F}$ \\
\hline Experimentos (Z) & $\mathrm{z}-1$ & $\sigma_{\mathrm{e}}^{2}+R \sigma_{\mathrm{p} z}^{2}+P \sigma_{\mathrm{r} / \mathrm{z}}^{2}+R P V_{z}$ & $\mathrm{Q}_{1}$ & $\mathrm{Q}_{1} / \mathrm{Q}_{7}$ \\
\hline Repetições (R)/Z & $(\mathrm{r}-1) \mathrm{z}$ & $\sigma_{e}^{2}+P \sigma_{r / z}^{2}$ & $\mathrm{Q}_{2}$ & $\mathrm{Q}_{2} / \mathrm{Q}_{11}$ \\
\hline Tratamentos (G) & $g-1$ & $\sigma_{\mathrm{e}}^{2}+R \sigma_{\mathrm{gz}}^{2}+R Z V_{\mathrm{g}}$ & $\mathrm{Q}_{3}$ & $\mathrm{Q}_{3} / \mathrm{Q}_{7}$ \\
\hline Progênies(P) & $\mathrm{p}-1$ & $\sigma_{\mathrm{e}}^{2}+R \sigma_{\mathrm{pz}}^{2}+R Z V_{\mathrm{p}}$ & $\mathrm{Q}_{4}$ & $\mathrm{Q}_{4} / \mathrm{Q}_{8}$ \\
\hline Testemunhas (T) & $\mathrm{t}-1$ & $\sigma_{e}^{2}+R \sigma_{t z}^{2}+R Z V_{t}$ & $\mathrm{Q}_{5}$ & $\mathrm{Q}_{5} / \mathrm{Q}_{9}$ \\
\hline P vs T & 1 & $\sigma_{\mathrm{e}}^{2}+R \sigma_{p t z}^{2}+R Z V_{p t}$ & $\mathrm{Q}_{6}$ & $\mathrm{Q}_{6} / \mathrm{Q}_{10}$ \\
\hline $\mathrm{G} \times \mathrm{Z}$ & $(g-1)(z-1)$ & $\sigma_{\mathrm{e}}^{2}+R \sigma_{\mathrm{g} z}^{2}$ & $\mathrm{Q}_{7}$ & $\mathrm{Q}_{7} / \mathrm{Q}_{11}$ \\
\hline$P \times Z$ & $(p-1)(z-1)$ & $\sigma_{\mathrm{c}}^{2}+R \sigma_{\mathrm{pz}}^{2}$ & $\mathrm{Q}_{8}$ & $\mathrm{Q}_{8} / \mathrm{Q}_{11}$ \\
\hline$T \times Z$ & $(\mathrm{t}-1)(\mathrm{z}-1)$ & $\sigma_{e}^{2}+R \sigma_{t z}^{2}$ & $\mathrm{Q}_{9}$ & $\mathrm{Q}_{9} / \mathrm{Q}_{11}$ \\
\hline$(\mathrm{P}$ vs $\mathrm{T}) \times \mathrm{Z}$ & $1(z-1)$ & $\sigma_{\mathrm{e}}^{2}+R \sigma_{\mathrm{ptz}}^{2}$ & $\mathrm{Q}_{10}$ & $\mathrm{Q}_{10} / \mathrm{Q}_{11}$ \\
\hline Resíduo & $\mathrm{I}(\mathrm{r}-1)(\mathrm{g}-1)$ & $\sigma_{e}^{2}$ & $Q_{11}$ & \\
\hline Total & $(\mathrm{zrgpt})-1$ & & & \\
\hline
\end{tabular}




\section{LISTA DE SIGLAS :}

- NDM: número de dias para maturidade;

- APM: altura de planta na maturidade;

- Ac: acamamento;

- VA: valor agronômico;

- CHS: sintomas de cancro-da-haste da soja;

- PG: produtividade de grãos;

- PPR: progênies precoces;

- PSP: progênies semi-precoces;

- PIN: progênies intermediárias;

- PST: progênies semi-tardias;

- CM: ciclo de maturação;

- CMP: ciclo de maturação precoce;

- CMSP: ciclo de maturação semi-precoce;

- CMI: ciclo de maturação intermediário;

- CMST: ciclo de maturação semi-tardio;

- ESA 95/6: local ESALQ ano 1995/96;

- ESA 96/7: local ESALQ ano 1996/97;

- ANH 96/7: local Anhembi ano 1996/97:

- ESA 97/8: local ESALQ ano 1997/98;

- ANH 97/8: local Anhembi ano 1997/98:

- ARE 97/8: local Areão ano 1997/98. 